\title{
Effects of Tensile Loading on Upper Shelf Fracture Toughness
}

1190

466181 لd

$0 \pm N \exists \supset \exists \forall$

Prepared by

J. A. Joyce/USNA

R. E. Link/NSWC

\section{U.S. Naval Academy}

Naval Surface Warfare Center

Prepared for

U.S. Nuclear Regulatory Commission 


\section{AVAILABILITY NOTICE}

Availability of Reference Materials Cited in NRC Publications

Most documents cited in NRC publications will be avallable from one of the following sources:

i. The NRC Public Document Room, 2120 L Street, NW., Lower Level, Washington, DC 20555-0001

2. The Superintendent of Documents, U.S. Government Printing Office, Mail Stop SSOP, Washington, DC 20402-9328

3. The National Technical Information Service, Springfield, VA 22161

Although the listing that follows represents the majority of documents cited in NRC publications, It is not intended to be exhaustive.

Referenced documents avallable for inspection and copying for a fee from the NRC Public Document Room include NRC correspondence and internal NRC memoranda: NRC bulletins, clrculars, information notices, Inspection and investigation notices; licensee event reports; vendor reports and correspondence; Commission papers; and applicant and licensee documents and correspondence.

The following documents in the NUREG series are available for purchase from the GPO Sales Program: formal NRC staff and contractor reports, NRC-sponsored conference proceedings, International agreement reports, grant publications, and NRC booklets and brochures. Also avallable are regulatory guides, NRC regulations in the Code of Federal Regulations, and Nuclear Regulatory Commission Issuances.

Documents available from the National Technical Information Service include NUREG-series reports and technical reports prepared by other Federal agencies and reports prepared by the Atomic Energy Commission. forerunner agency to the Nuclear Regulatory Commission.

Documents available from public and special technical libraries include all open literature Hems, such as books, journal articles, and transactions. Federal Register notices, Federal and State legislation, and congressional reports can usually be obtained from these libraries.

Documents such as theses. dissertations, foreign reports and translations, and non-NRC conference proceedings are available for purchase from the organization sponsoring the publication cited.

Single copies of NRC draft reports are available free, to the extent of supply, upon written request to the Office of Administration, Distribution and Mail Services Section, U.S. Nuclear Regulatory Commission, Washington, DC 20555-0001.

Copies of industry codes and standards used in a substantive manner in the NRC regulatory process are maintained at the NRC Library, 7920 Norfolk Avenue. Bethesda. Maryland, for use by the public. Codes and standards are usually copyrighted and may be purchased from the originating organization or, If they are American National Standards, from the American National Standards Instltute, 1430 Broadway. New York, NY 10018.

\section{DISCLAIMER NOTICE}

This report was prepared as an account of work sponsored by an agency of the United States Government. Neither the United States Government nor any agency thereof, or any of their employees, makes any warranty, expressed or implied, or assumes any legal liability of responsibility for any third party's use, or the results of such use, of any information, apparatus, product or process disclosed in this report, or represents that its use by such third party would not infringe privately owned rights. 


\section{DISCLAIMER}

This report was prepared as an account of work sponsored by an agency of the United States Government. Neither the United States Government nor any agency Thereof, nor any of their employees, makes any warranty, express or implied, or assumes any legal liability or responsibility for the accuracy, completeness, or usefulness of any information, apparatus, product, or process disclosed, or represents that its use would not infringe privately owned rights. Reference herein to any specific commercial product, process, or service by trade name, trademark, manufacturer, or otherwise does not necessarily constitute or imply its endorsement, recommendation, or favoring by the United States Government or any agency thereof. The views and opinions of authors expressed herein do not necessarily state or reflect those of the United States Government or any agency thereof. 


\section{DISCLAIMER}

Portions of this document may be illegible in electronic image products. Images are produced from the best available original document. 
NUREG/CR-6051

\section{Effects of Tensile Loading on Upper Shelf Fracture Toughness}

Manuscript Completed: November 1993

Date Published: March 1994

Prepared by

J. A. Joyce, U.S. Naval Academy

R. E. Link, Naval Surface Warfare Center

U.S. Naval Academy

Annapolis, MD 21402

Naval Surface Warfare Center

Annapolis, MD 21402

Prepared for

Division of Engineering

Office of Nuclear Regulatory Research

U.S. Nuclear Regulatory Commission

Washington, DC 20555-0001

NRC FIN J6036 



\section{ABSTRACT}

Constraint has been an important consideration in fracture mechanics from the earliest work that was done to develop the 1974 version of the ASTM Standard E399. Stringent thickness and size requirements were placed on the test samples, in terms of the measured plastic zone size. These requirements often invalidate the results in practical application sizes. Similar size requirements have been incorporated into more recent elastic-plastic fracture test standards like ASTM E813 and ASTM E1152, even though experimental data has not shown a clear and direct relationship between specimen size and the resulting initiation toughness or the resistance curve shape.

O'Dowd and Shih (1991) have proposed that the difference in crack tip stress fields between the SSY finite element solution and the finite body solution can be quantified in terms of a field quantity that they have call $Q$. The $Q$ quantity is a function of $J$, the crack shape and size, the structural geometry, mode of loading and on the level of deformation and can only be calculated from a high resolution elastic-plastic computational analysis. O'Dowd and Shih propose that a J-Q fracture locus can be developed experimentally for a particular material, with higher Q's meaning higher constraint and resulting in lower $\mathrm{J}$ measures at cleavage or at ductile crack initiation, or at whatever critical measurement point is to be used. This procedure avoids the need to start with a fracture criterion, which is a serious difficulty if one wishes to apply the Dodds and Anderson approach to the case of ductile crack extension.

A similar, simpler, but more controversial approach has been suggested by Betégon and Hancock (1991), who use the non-singular term of the elastic, Williams (1957), crack singularity solution, called the T-Stress", as a measure of elastic-plastic crack tip constraint. This quantity is only dependent on the initial geometry and loading and hence is relatively easy to calculate, and is available in the literature for many geometries.

The objective of this work is to develop some upper shelf, elastic-plastic experimental results to attempt to investigate the applicability of the $Q$ and $T$ stress parameters to the correlation of upper shelf initiation toughness and $\mathrm{J}$ resistance curves. The first objective was to obtain upper shelf $\mathrm{J}$ resistance curves, $\mathrm{J}_{\mathrm{lc}}$, and tearing resistance, $\mathrm{T}_{\operatorname{mat}}$, results for a range of applied constraint. The J-Q and J-T stress loci were developed and compared with the expectations of the O'Dowd and Shih and the Betégon and Hancock analyses. Constraint was varied by changing the crack length and also by changing the mode of loading from bending to predominantly tensile.

The principle conclusions of this work are that $J_{I c}$ does not appear to be dependent on $T$ stress or $\mathrm{Q}$ while the material tearing resistance is dependent on $\mathrm{T}$ stress and $\mathrm{Q}$, with the tearing modulus increasing as constraint decreases. 


\section{TABLE OF CONTENTS}

Page

ABSTRACT $\ldots \ldots \ldots \ldots \ldots \ldots \ldots \ldots \ldots \ldots \ldots \ldots \ldots \ldots \ldots$

TABLE OF CONTENTS $\ldots \ldots \ldots \ldots \ldots \ldots \ldots \ldots \ldots$

LIST OF FIGURES $\ldots \ldots \ldots \ldots \ldots \ldots \ldots \ldots \ldots \ldots \ldots \ldots$

LIST OF TABLES $\ldots \ldots \ldots \ldots \ldots \ldots \ldots \ldots \ldots \ldots \ldots \ldots \ldots \ldots$

PRIOR REPORTS $\ldots \ldots \ldots \ldots \ldots \ldots \ldots \ldots \ldots \ldots \ldots \ldots \ldots \ldots \ldots$

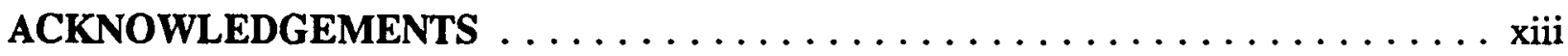

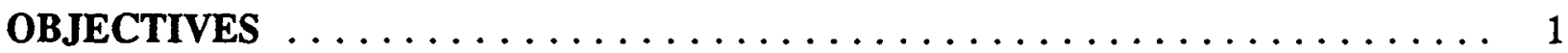

1.0 EXPERIMENTAL DETAILS $\ldots \ldots \ldots \ldots \ldots \ldots \ldots \ldots \ldots$

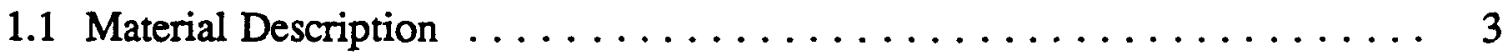

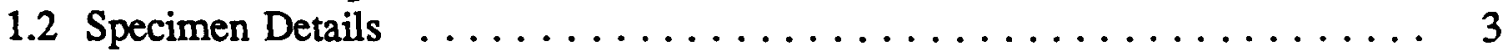

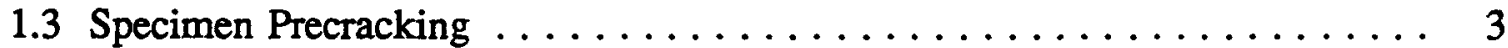

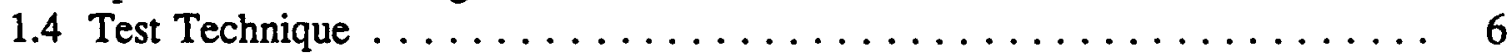

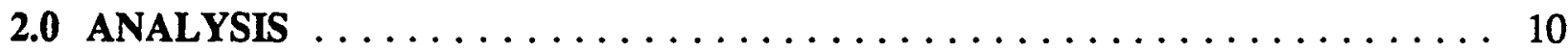

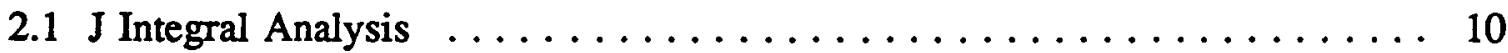

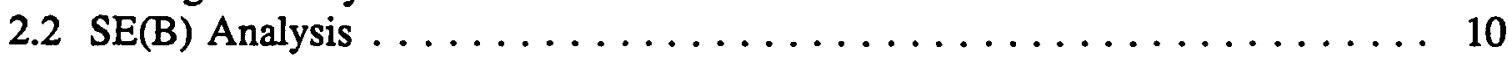

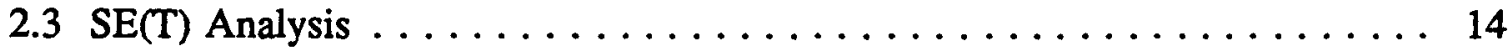

$2.3 .1 \mathrm{SE}(\mathrm{T}) \mathrm{K}$ Expression $\ldots \ldots \ldots \ldots \ldots \ldots \ldots \ldots \ldots \ldots \ldots \ldots$

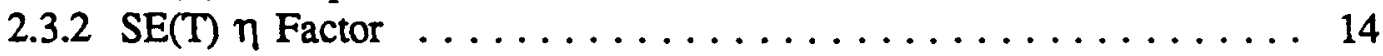

2.3.3 SE(T) Crack Length Estimation $\ldots \ldots \ldots \ldots \ldots \ldots \ldots$

2.3.4 SE(T) Rotation Correction . . . . . . . . . . . . . . . . . . . 18

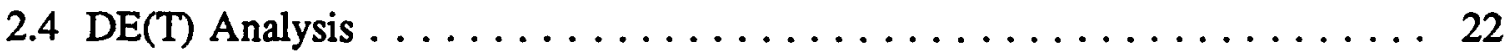

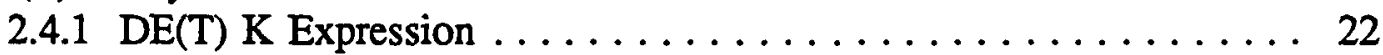

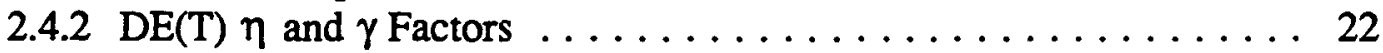

$2.4 .3 \mathrm{DE}(\mathrm{T})$ Crack Length Estimation . . . . . . . . . . . . . . . . 23

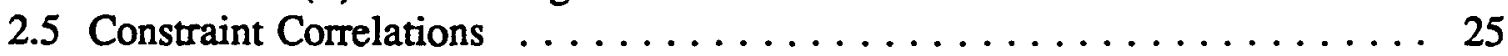

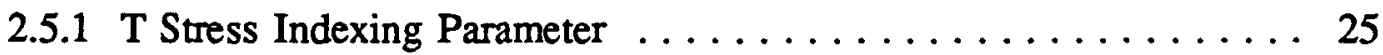

2.5.2 The $Q$ Indexing Parameter $\ldots \ldots \ldots \ldots \ldots \ldots \ldots \ldots \ldots$

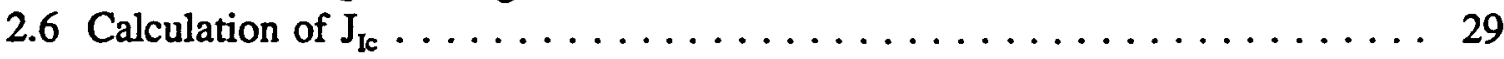

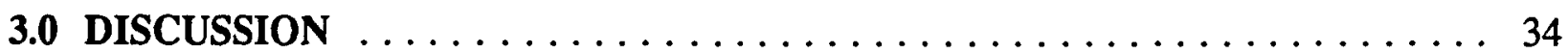

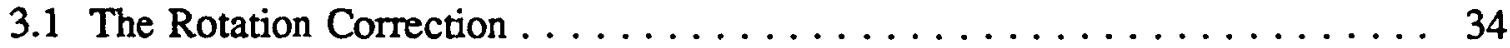

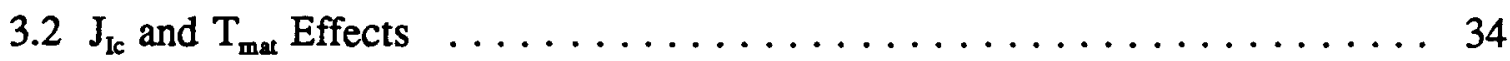

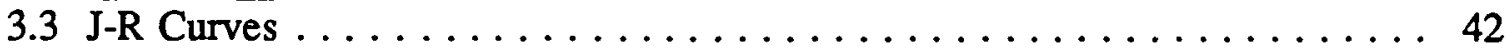




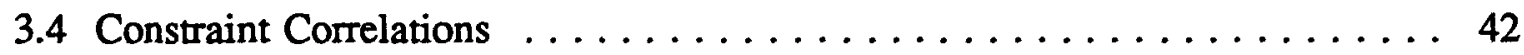

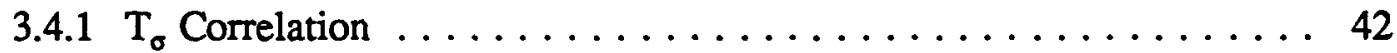

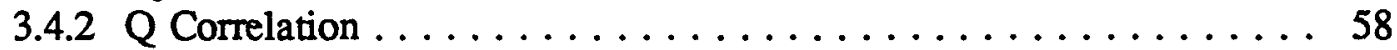

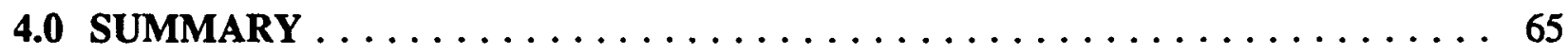

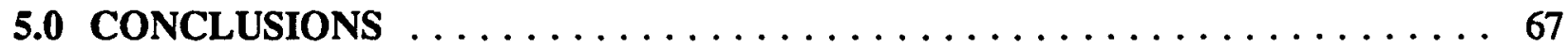

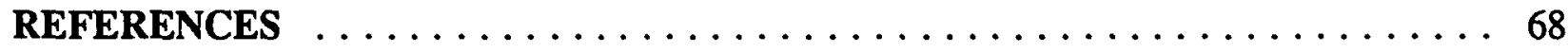

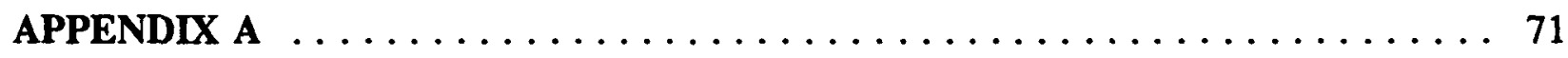




\section{LIST OF FIGURES}

No. $\quad \underline{\text { Page }}$

Figure 1 Schematic drawings of the $\mathrm{SE}(\mathrm{T})$ and $\mathrm{DE}(\mathrm{T})$ geometries tested in this

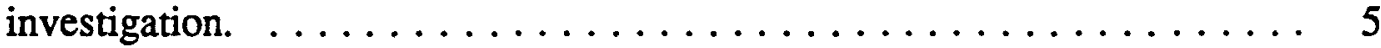

Figure $2 \quad$ Predicted plastic $\eta$ factors for $S E(B)$ specimens. . . . . . . . . . 13

Figure 3 Comparison of stress intensity factor relationships for the SE(T) specimen. ............................... 15

Figure $4 \quad$ Predicted plastic $\eta$ factors for the $S E(T)$ geometry $\ldots \ldots \ldots \ldots$

Figure 5 Geometric relationship of variables used in rotation correction development. ........................ 20

Figure $6 \quad$ Predicted plastic $\eta$ factors for the $\mathrm{DE}(\mathrm{T})$ specimen. . . . . . . . . . . 24

Figure $7 \quad$ Biaxiality factor, $\beta$, for three specimen geometries. . . . . . . . . . 26

Figure 8 The $\mathrm{Q}$ constraint factor for $\mathrm{SE}(\mathrm{B})$ specimens with short and deep cracks,

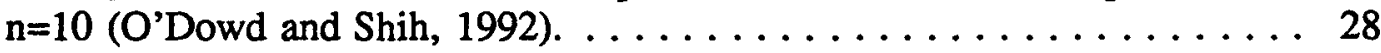

Figure 9 The $Q$ constraint parameter for the $S E(T)$ specimen with $a / W=0.4, n=10$ (R.H. Dodds, Private Communication). . . . . . . . . . . . . 30

Figure 10 The $Q$ constraint parameter for the $S E(T)$ specimen, $a / W=0.6, n=10$ (R.H. Dodds, Private communication). ................ 31

Figure 11 The $Q$ constraint parameter for the $D E(T)$ specimen with $a / W=0.7, n=10$ (R.H. Dodds, Private communication). . . . . . . . . . . . 32

Figure 12 Polynomial fit of crack length versus $\mathrm{J}$ for determining the best-fit initial

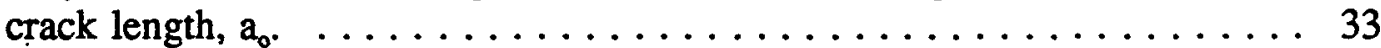

Figure 13 J-Resistance curve from an SE(T) specimen exhibiting "crack backup" in the early portion of the test. .................. 35

Figure 14 Comparison of J-R curves for an HY-100 SE(T) specimen with and without rotation correction. ..................... 36

Figure $15 \mathrm{~J}-\mathrm{R}$ curve for an $\mathrm{HY}-100 \mathrm{SE}(\mathrm{T})$ specimen with and without rotation correction. ....................... 37

Figure 16 Fracture toughness of $\mathrm{HY}-100$ as a function of specimen type. . . . . . 40 
Figure 17 Fracture toughness of A533B as a function of specimen type. . . . . 41

Figure 18 Tearing modulus of HY-100 as a function of specimen type. . . . . 43

Figure 19 Tearing modulus of A533B as a function of specimen type. . . . . . . 44

Figure 20 Baseline J-R curves for HY-100 from deep-cracked SE(B) specimens. . . . 45

Figure 21 Baseline $J-R$ curves for A533B from deep-cracked $S E(B)$ and $C(T)$ specimens. ....................... 46

Figure $22 \quad J-R$ curves for HY-100 from short-cracked SE(B) specimens. . . . . . . 47

Figure $23 \quad \mathrm{~J}-\mathrm{R}$ curves for A533B from short-cracked SE(B) specimens. $\ldots \ldots \ldots .48$

Figure 24 J-R curves for HY-100 from SE(T) specimens (with rotation correction). . . 49

Figure $25 \mathrm{~J}-\mathrm{R}$ curves for A533B from $\mathrm{SE}(\mathrm{T})$ specimens (with rotation correction). $\quad . \quad 50$

Figure $26 \mathrm{~J}-\mathrm{R}$ curves for $\mathrm{HY}-100$ from $\mathrm{DE}(\mathrm{T})$ specimens. $\ldots \ldots \ldots \ldots \ldots \ldots$

Figure $27 \quad \mathrm{~J}-\mathrm{R}$ curves for A533B from $\mathrm{DE}(\mathrm{T})$ specimens. $\ldots \ldots \ldots \ldots \ldots \ldots$

Figure $28 \quad$ Load versus COD curves for specimens SEN9 and SEN1 of A533B. . . 53

Figure 29 Fracture toughness, $J_{I c}$, as a function of $T_{\sigma}$ for the HY-100 specimens. . . 56

Figure 30 The fracture toughness, $J_{I c}$, as a function of $T_{\sigma}$ for the A533B specimens. .......................... 104

Figure 31 Tearing modulus, $T_{\text {mat }}$ as a function of $T_{\sigma}$ for the HY-100 specimens. . . 59

Figure 32 Tearing modulus, $T_{\text {mat }}$, as a function of $T_{\sigma}$ for the A533B specimens. . . 60

Figure 33 Fracture toughness, $\mathrm{J}_{\mathrm{I}}$, as a function of $\mathrm{Q}$ for the HY-100 specimens. . . 61

Figure 34 Fracture toughness, $\mathrm{J}_{\mathrm{Ic}}$, as a function of $\mathrm{Q}$ for the A533B specimens. . . 62

Figure 35 Tearing modulus, $T_{\text {mat }}$, as a function of $Q$ for the HY-100 specimens. . . 63

Figure 36 Tearing modulus, $T_{\text {mat, }}$ as a function of $Q$ for the A533B specimens. . . . 64

Figure 37 Comparison of J-Resistance curves calculated using three different $\mathrm{J}$ formulations. . . . . . . . . . . . . . . . . . 66 


\section{LIST OF TABLES}

No.

Table 1 Chemical composition and mechanical properties of steel alloys used in this investigation (All element values in weight percent). ........ 4

Table 2 List of $\mathrm{HY}-100$ specimens tested in this investigation. . . . . . . 7

Table 3 List of A533B specimens tested in this investigation. $\ldots \ldots \ldots \ldots$

Table $4 \quad$ Fracture toughness and tearing modulus for HY-100 specimens. . . . . 38

Table 5 Fracture toughness and tearing modulus for A533B specimens. . . . . . 39

Table 6 Constraint parameters $\beta, T_{\sigma}$, and $Q$ at crack initiation in the HY-100 specimens. ...................... 54

Table 7 Constraint parameters $\beta, T_{\sigma}$, and $Q$ at crack initiation for the A533B

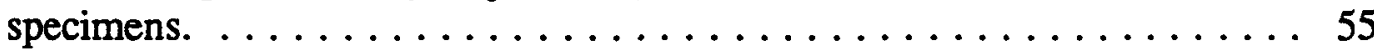




\section{PRIOR REPORTS}

Prior reports is this series are listed below:

1. J. A. Joyce, "Application of the Key Curve Method to Determining J-R Curves for A533B Steel," NUREG/CR-1290, U.S. Nuclear Regulatory Commission, Washington, DC (January 1980).

2. J. P. Gudas, M. G. Vassilaros, J. A. Joyce, D. A. Davis, and D. R. Anderson, "Summary of Recent Investigations of Compact Specimen Geometry Effects on the $\mathrm{J}_{1}-\mathrm{R}$ Curve of High Strength Steels," NUREG/CR-1813, U.S. Nuclear Regulatory Commission, Washington, DC (November 1980).

3. J. A. Joyce, "Static and Dynamic J-R Curve Testing of A533B Steel Using the Key Curve Analysis Technique," NUREG/CR-2274, U.S. Nuclear Regulatory Commission, Washington, DC (July 1981).

4. J. A. Joyce, "Instability Testing of Compact and Pipe Specimens Utilizing a Test System Made Compliant by Computer Control," NUREG/CR-2257, U.S. Nuclear Regulatory Commission, Washington, DC (March 1982).

5. M. G. Vassilaros, J. P. Gudas, and J. A. Joyce, "Experimental Investigation of Tearing Instability Phenomena for Structural Materials," NUREG/CR-2570, Rev. 1, U.S. Nuclear Regulatory Commission, Washington, DC (August 1982).

6. Davis, D.A., Vassilaros, M.G., and Gudas, J.P., "Specimen Geometry and Extended Crack Growth Effects on $\mathrm{J}_{\mathrm{I}}-\mathrm{R}$ Curve Characteristics for HY-130 and ASTM A533B Steels," USNRC Report NUREG/CR-3089, U.S. Nuclear Regulatory Commission, Washington, DC (November 1982).

7. Vassilaros, M.G. et al., "J-Integral Tearing Instability for 8-Inch Diameter ASTM A106 Steel Pipe." USNRC Report NUREG/cr-3740, U.S. Nuclear Regulatory Commission, Washington, DC (March 1984).

8. J. A. Joyce, "Development and Verification of Conditions for Ductile Tearing Instability and Arrest," NUREG/CR-4528, U.S. Nuclear Regulatory Commission, Washington, DC (February 1986).

9. Hays, R.A., Vassilaros, M.G., and Gudas, J.P., "Fracture Analysis of Welded Type 304 Stainless Steel Pipe," USNRC Report NUREG/CR-4538 Vol. 1, U.S. Nuclear Regulatory Commission, Washington, DC (February 1986). 
10. Link, R.E., and Hays, R.A., "Investigation of Tearing Instability Phenomena in ASTM A106 Steel," USNRC Report NUREG/CR-4539, U.S. Nuclear Regulatory Commission, Washington, DC (February 1986).

11. Hackett, E.M., Kirk, M.T., and Hays, R.A., "An Evaluation of J-R Curve Testing of Nuclear Piping Materials Using the Direct Current Potential Drop Technique," USNRC Report NUREG/CR-4540, U.S. Nuclear Regulatory Commission, Washington, DC (June 1986).

12. J. A. Joyce and E. M. Hackett, "Application of the Key Curve and Multispecimen Techniques to Dynamic J-R Curve Testing of Alloy Steel, "NUREG/CR-4579, U.S. Nuclear Regulatory Commission, Washington, DC (April 1986).

13. J. A. Joyce and C. S. Schneider, "Application of Alternating Current Potential Difference to Crack Length Measurement During Rapid Loading," NUREG/CR-4699, U.S. Nuclear Regulatory Commission, Washington, DC (August 1986).

14. J. A. Joyce and E. M. Hackett, "Development of an Analytic Key Curve Approach to Drop Tower J-R Curve Measurement," NUREG/CR-4782, U.S. Nuclear Regulatory Commission, Washington, DC (December 1986).

15. J. A. Joyce and E. M. Hackett, "Transition Range Drop Tower J-R Curve Testing of A106 Steel," NUREG/CR-4818, U.S. Nuclear Regulatory Commission, Washington, DC (February 1987).

16. J. A. Joyce "Ductile to Brittle Toughness Transition Characterization of A533B Steel," NUREG/CR-5142, U.S. Nuclear Regulatory Commission, Washington, DC (June 1988).

17. J. A. Joyce, D. A. Davis, E. M. Hackett, and R. A. Hays, "Application of the J-Integral to Cases of Large Crack Extension," NUREG/CR-5143, U.S. Nuclear Regulatory Commission, Washington, DC (February 1989).

18. J. A. Joyce and E. M. Hackett, "Development of an Engineering Definition of the Extent of J Singularity Controlled Crack Growth," NUREG/CR-5238, U.S. Nuclear Regulatory Commission, Washington, DC (May 1989).

19. J. A. Joyce and E. M. Hackett, "Extension and Extrapolation of J-R Curves and Their Application to the Low Upper Shelf Toughness Issue," NUREG/CR-5577, U.S. Nuclear Regulatory Commission, Washington, DC (March 1991). 
20. J. A. Joyce, E. M. Hackett, and C. Roe, "Comparison of $\mathrm{J}_{\mathrm{Ic}}$ and J-R Curves for Short Crack and Tensiley Loaded Specimen Geometries of a High Strength Structural Steel," NUREG/CR-5879, U.S. Nuclear Regulatory Commission, Washington, DC (November 1992).

21. O'Dowd, N.P. and Shih, C.F., "Two-Parameter Fracture Mechanics: Theory and Applications," NUREG/CR-5958, U.S. Nuclear Regulatory Commission, Washington, DC (February 1993).

22. Kirk, M.T. and Dodds, R.H., Jr., "J and CTOD Estimation Equations for Shallow Cracks in Single Edge Notch Bend Specimens," NUREG/CR-5969, U.S. Nuclear Regulatory Commission, Washington, DC (July 1993).

23. Kirk, M.T. and Dodds, R.H., Jr., "Approximate Techniques for Predicting Size Effects on Cleavage Fracture Toughness $\left(J_{c}\right)$," NUREG/CR-5970, U.S. Nuclear Regulatory Commission, Washington, DC (July 1993).

24. Dodds, R.H., Jr., Shih, C.F., and Anderson, T.L., "Continuum and Micromechanics Treatment of Constraint in Fracture," NUREG/CR-5971, U.S. Nuclear Regulatory Commission, Washington, DC (July 1993).

25. Joyce, J.A. and Link, R.E., "The Effect of Electric Discharge Machined Notches on the Fracture Toughness of Several Structural Alloys," NUREG/CR-5981, U.S. Nuclear Regulatory Commission, Washington, DC (September 1993). 


\section{ACKNOWLEDGEMENTS}

This work was performed at the U.S. Naval Academy under the program "Elastic-Plastic Fracture Evaluation of LWR Alloys," R. E. Link of the Naval Surface Warfare Center, Annapolis, $M D$, Program Manager. The program is sponsored by the Office of Nuclear Regulatory Research of the U.S. Nuclear Regulatory Commission (NRC). The technical monitor for the NRC was Mr. Shah Malik. The authors would like to acknowledge the help of Mr. Wayne Farmer and Mr. John Hein of the U.S. Naval Academy for technical assistance with several aspects of this project, and also the Technical Support Department of the U.S. Naval Academy Engineering and Weapons Division for specimen and fixture machining. 


\section{OBJECTIVES}

Constraint has been an important consideration in fracture mechanics from the earliest work that was done to develop the 1974 version of the ASTM Standard E399. Stringent thickness and size requirements were placed on the test samples, in terms of the measured plastic zone size. These requirements often invalidated the results in practical application sizes. The restrictions have been retained in later revisions, often requiring the engineer to test in his application thickness and to work generally with "invalid" data, using engineering judgement and experience to avoid catastrophic failure of his structure. Similar size requirements have been incorporated into more recent elastic-plastic fracture test standards like ASTM E813 and ASTM E1152, even though experimental data has not shown a clear and direct relationship between specimen size and the resulting initiation toughness or the resistance curve shape.

Recent computational work by Anderson and Dodds (1991) and Dodds, Anderson and Kirk (1991) has sought to quantify constraint by comparing the stress field near a crack in an elastic-plastic body to the small-scale yielding (SSY) solution that corresponds to that geometry and material combination, as also determined by numerical computation. This SSY solution has been shown to be basically different than the Hutchinson (1968), Rice and Rosengren (1968) (HRR) solution, apparently due to the crack tip blunting which is invariably present near the crack tip. The Dodds, et al work has shown that constraint depends on specimen or structure thickness, on in-plane dimensions, and on the mode of loading. They also showed that the principal stress fields in two-dimensional cases are self-similar and a comparison of similar stressed volumes can be made which allows a comparison of constraint from one situation to another, i.e. a short-cracked bend geometry can be chosen to match the constraint of a much harder to test short cracked tensile geometry. In addition, they developed a scaling model to predict the effect of changes in constraint on the cleavage fracture toughness.

The Dodds, et al. scaling model has been applied predominantly to cleavage fracture, since as presently formulated, it assumes a fracture criteria similar to that proposed by Ritchie, Knott, and Rice (1973) (fracture occurs when the maximum principal stress reaches a critical value, $\sigma_{f}$, at a critical distance, $r^{*}$, from the crack tip). By scaling the remote $J$ integral to achieve similar stress conditions near the crack tip a correction of the $J$ integral values at cleavage initiation can be made which accounts, at least approximately, for the effects of constraint on fracture. The applicability of this technique in the lower shelf ductile-brittle transition regime of ferritic steels has been demonstrated by Sorem, Dodds and Rolfe (1991) and by Kirk, Koppenhoefer and Shih (1993).

O'Dowd and Shih (1991) have proposed that the difference in crack tip stress fields between the SSY solution and the finite body solution can be quantified in terms of a field quantity that they have call $\mathrm{Q}$. The $\mathrm{Q}$ quantity is a function of $\mathrm{J}$, the crack shape and size, the structural geometry, mode of loading and on the level of deformation and can only be calculated from a high resolution elastic-plastic computational analysis. O'Dowd and Shih propose that a $\mathrm{J}-\mathrm{Q}$ fracture locus can be developed experimentally for a particular material, with higher Q's meaning higher constraint and resulting in lower $\mathrm{J}$ measures at cleavage or at ductile crack 
initiation, or at whatever critical measurement point is to be used. This procedure avoids the need to start with a fracture criterion, which is a serious difficulty if one wishes to apply the Dodds and Anderson approach to the case of ductile crack extension. Examples of a J-Q fracture locus for the case of cleavage have been developed by Kirk, Koppenhoeffer and Shih (1993) and also by Sumpter and Forbes (1993), and these results seem to support the J-Q concept.

A similar, simpler, but more controversial approach has been suggested by Betégon and Hancock (1991), who use the first non-singular term of the elastic crack-tip stress field solution (Williams 1957) as a measure of elastic-plastic crack tip constraint. This quantity has been called the "T-stress", a notation used by Larsson and Carlsson (1973) who studied the effect of this term on the crack tip stress field. This quantity is only dependent on the initial geometry and loading and hence is relatively easy to calculate, and is available in the literature for many geometries. The application of this elastic quantity to elastic-plastic fracture is highly controversial, but published results have shown good correlation, and the ease of use is a strong selling point for this parameter.

The objective of this work is to develop some upper shelf, elastic-plastic experimental results to investigate the applicability of the $Q$ and $T$ stress parameters to the correlation of upper shelf initiation toughness and $\mathrm{J}$ resistance curves. The first objective was to obtain upper shelf $\mathrm{J}$ resistance curves, $\mathrm{J}_{\mathrm{Ic}}$, and tearing resistance, $\mathrm{T}_{\mathrm{mat}}$, results for a range of applied constraint. The $\mathrm{J}-\mathrm{Q}$ and J-T stress loci were developed and compared with the expectations of the O'Dowd and Shih and the Betégon and Hancock analyses. Constraint was varied by changing the crack length and also by changing the mode of loading from bending to predominantly tensile. Test techniques and analysis have been developed as needed for the low constraint fracture test geometries. Two materials have been used in this study, an HY-100 high strength structural steel and an A533B pressure vessel steel. Some of the results for the HY-100 steel have been reported previously in NUREG/CR-5879 (Joyce, et.al. 1992), they are repeated again here to demonstrate the consistency of the results found for the two materials. 


\subsection{EXPERIMENTAL DETAILS}

\subsection{Material Description}

Two structural steels were tested in this study. The first material was HY-100, a high strength structural steel with tensile mechanical properties and chemistry as shown in Table 1. This material was from a $6.35 \mathrm{~cm}$ thick plate and all specimens were oriented so that the crack plane was in the T-L direction as designated by ASTM E399. The second material was an ASTM A533 Grade B pressure vessel steel with the tensile mechanical properties and chemistry also shown in Table 1 . The plate for this material was originally $21.5 \mathrm{~cm}$ thick, but for these tests all samples were cut from the center $15 \mathrm{~cm}$. All specimens of this material were oriented in the L-T orientation.

\subsection{Specimen Details}

Four distinct test geometries were studied in this work: the standard $1 \mathrm{~T}$ compact specimen $C(T)$, the single edge-notched bend specimen $\mathrm{SE}(\mathrm{B})$, the single edge-notched tensile specimen, $\mathrm{SE}(\mathrm{T})$ that was pin-loaded and the double edge-notched tensile, $\mathrm{DE}(\mathrm{T})$, specimen, also pin-loaded. The SE(B) specimens were tested in a standard deep notched configuration with crack length specimen width ratio $\mathrm{a} / \mathrm{W}=0.6$, and also in a shallow notched configuration with $\mathrm{a} / \mathrm{W}=0.15$. The $S E(T)$ and $D E(T)$ configurations were tested with a/W ratios from 0.35 to 0.7 . Schematic drawings of the $\operatorname{SE}(\mathrm{T})$ and $\mathrm{DE}(\mathrm{T})$ geometries are shown in Figure 1. All specimens were $25 \mathrm{~mm}$ thick and side grooved to a total thickness reduction of $20 \%$. All specimens were side grooved after precracking.

Some non-side grooved specimens of the HY-100 steel were tested and reported in Joyce, et al. (1992), however all specimen results presented here are for specimens which have been side grooved to a total reduction of $20 \%$. Matrices of the test specimens are presented in Table 2 and 3 for the two materials tested and reported here.

Tests of the HY-100 steel were done at ambient temperature $\left(25^{\circ} \mathrm{C}\right)$, while the $\mathrm{A} 533 \mathrm{~B}$ was tested at approximately $100^{\circ} \mathrm{C}$ to assure that the fracture mode for all tests were fully ductile throughout.

\subsection{Specimen Precracking}

The bend specimens and the tensile bars were precracked in bending using a three point bend apparatus. The short cracked HY-100 bend specimens were precracked starting from a wide specimen, with $\mathrm{W}=70 \mathrm{~mm}$, and precracked until the crack was about $27 \mathrm{~mm}$ long. The specimens were subsequently machined to remove the material at the crack flanks, until a final configuration was obtained with a crack length of about $7 \mathrm{~mm}$ in a remaining ligament of 50 $\mathrm{mm}$. The precrack fronts obtained in this fashion for this material were found to be straight and accurate in all cases, but the method was expensive and arduous. The A533B short crack bend specimens were precracked by starting with a bar of width $50 \mathrm{~mm}$ with a short machined notch 
Table 1 Chemical composition and mechanical properties of steel alloys used in this investigation (All element values in weight percent).

\begin{tabular}{||l|c|c||}
\hline Element & $\begin{array}{c}\text { HY-100 } \\
\text { (FYO) }\end{array}$ & $\begin{array}{c}\text { A533, Grade B } \\
\text { (H13) }\end{array}$ \\
\hline Carbon & 0.16 & 0.22 \\
\hline Manganese & 0.26 & 1.48 \\
\hline Phosphorus & 0.003 & 0.012 \\
\hline Sulfur & 0.009 & 0.018 \\
\hline Silicon & 0.19 & 0.25 \\
\hline Nickel & 2.78 & 0.68 \\
\hline Chromium & 1.57 & - \\
\hline Molybdenum & 0.42 & - \\
\hline Vanadium & 0.003 & - \\
\hline $\begin{array}{l}\text { 0.2\% Yield Strength, } \\
\text { MPa (ksi) }\end{array}$ & $747(109)$ & $397(58)$ \\
\hline $\begin{array}{l}\text { Ultimate Strength, } \\
\text { MPa (ksi) }\end{array}$ & $877(128)$ & $555(81)$ \\
\hline $\begin{array}{l}\text { Elongation in 25 mm } \\
\text { (\%) }\end{array}$ & 16.5 & 26 \\
\hline $\begin{array}{l}\text { Reduction of Area } \\
\text { (\%) }\end{array}$ & 57 & 68 \\
\hline \hline
\end{tabular}



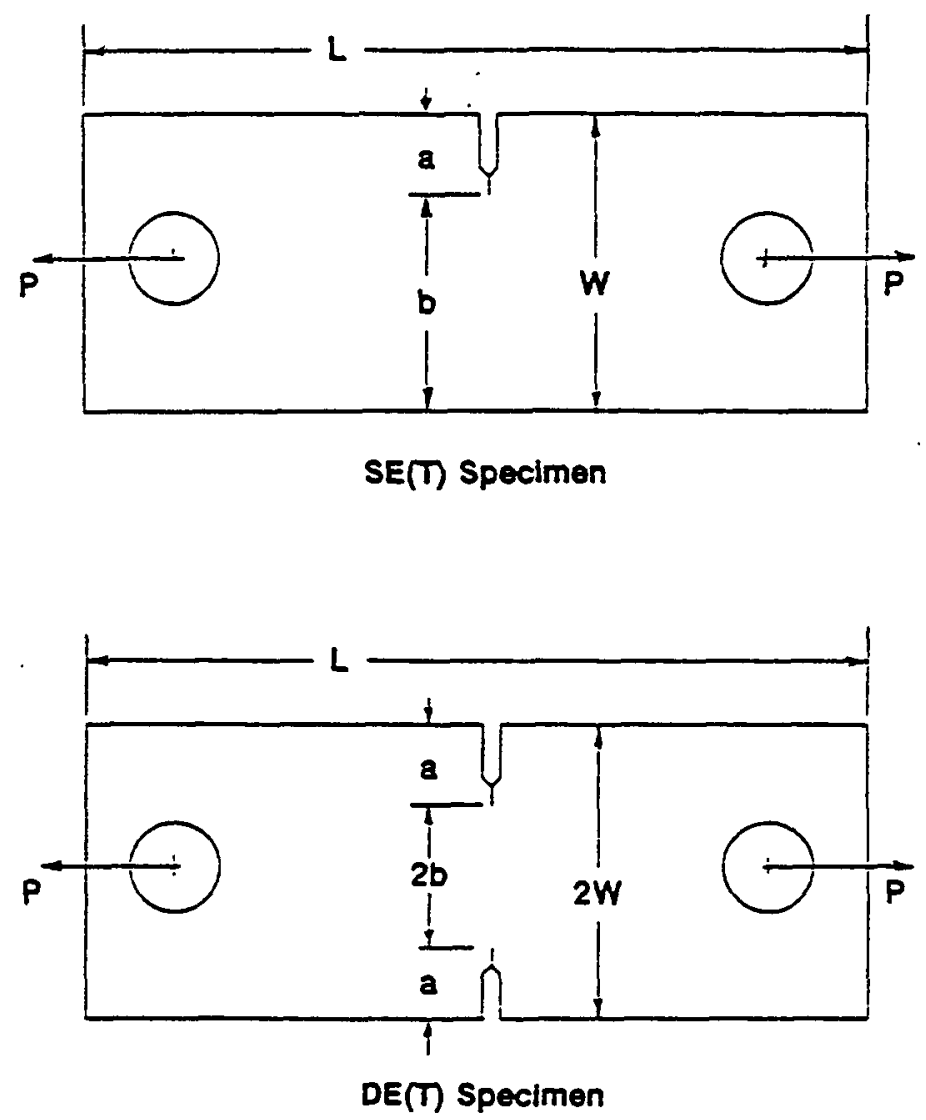

Figure 1 Schematic drawings of the $S E(T)$ and $D E(T)$ geometries tested in this investigation. 
$5 \mathrm{~mm}$ in depth. Then a single large reverse bending load was applied that was calculated to introduce a compressive plastic zone of $0.5 \mathrm{~mm}$ in extent. The specimen was then fatigue precracked as usual. The crack length was monitored using a computer controlled servohydraulic test machine, and the short crack compliance equation obtained by Joyce (1992), until the final precrack length of approximately $7 \mathrm{~mm}$ was obtained. These cracks were found to be straight, and the single load reversal method was much simpler than the double machining process used on the HY-100 short cracked bend specimens. This technique has become standard practice, even on large, shallow cracked bend bars.

The SE(T) specimens were precracked in three point bending, starting with machined notches with $\mathrm{a} / \mathrm{W}=0.15$, and grown to $\mathrm{a} / \mathrm{W}$ values of between 0.35 and 0.65 for testing. The $\mathrm{DE}(\mathrm{T})$ specimens were precracked in four point bending, with two rollers placed tightly across the compression side notch. The initial notch depths were kept at a/W $=0.15$ in the DE(T) specimens even though deep cracks were desired so that the ligament during precracking was a large as possible. A tightly fitting wedge was pushed into the compression side notch, and this allowed using standard bend compliance equations for monitoring the crack length of the $D E(T)$ specimens during precracking. The specimens were reversed several times to obtain even precracks on both sides. Matching the bend compliances in the two directions seemed to accurately match the lengths of the two cracks. As a final check the specimen was loaded in tension and the outputs of two clip gages mounted across the two cracks were compared. It was found, generally that the bending compliance matched cracks were of equal length and any remaining difference in COD output was usually do to misalignment of the test machine load train.

\subsection{Test Technique}

All tests were conducted using a single specimen, computer interactive, unloading compliance test procedure which allowed monitoring the specimen crack length and the applied $\mathrm{J}$ integral during the course of the test. Equations were presented in Joyce, et al. (1992) for the required elastic and plastic components of the $J$ integral and for estimating the crack length or lengths from the experimentally measured crack opening compliance. A simple rotation correction procedure greatly improves the crack length estimation accuracy of the SE(T) specimen. The rotation correction that is used here is similar to that used in ASTM E1152 for the $C(T)$ specimen, a correction that is, of course, used for the $C(T)$ specimens tested in this work. The $\operatorname{SE}(T)$ specimen rotation correction is developed in the next section. The results presented here for the HY-100 alloy SE(T) specimens are altered considerably from that reported previously (Joyce, et al. 1993) because the SE(T) specimen rotation correction is used here.

In all cases, crack growth corrected $\mathrm{J}$ equations are used here, as developed in Joyce, et al. (1992), which are similar to those required for the deep SE(B) specimens and the C(T) specimens by ASTM E1152. All data was stored on magnetic media for subsequent re-analysis as needed.

The SE(B) specimens were tested with standard bend fixtures which were made much 
Table 2 List of HY-100 specimens tested in this investigation.

\begin{tabular}{|c|c|c|c|c|c|c||}
\hline $\begin{array}{c}\text { Specimen } \\
\text { ID }\end{array}$ & Type & $\mathrm{a} / \mathrm{W}$ & $\begin{array}{c}\text { Side } \\
\text { Groove } \\
(\mathrm{Y} / \mathrm{N})\end{array}$ & $\begin{array}{c}\mathrm{B} \\
(\mathrm{mm})\end{array}$ & $\begin{array}{c}\mathrm{B}_{\mathrm{N}} \\
(\mathrm{mm})\end{array}$ & $\begin{array}{c}\mathrm{W} \\
(\mathrm{mm})\end{array}$ \\
\hline \hline FYO 1 & $\mathrm{SE}(\mathrm{B})$ & 0.66 & $\mathrm{Y}$ & 50. & 40. & 50. \\
\hline FYO 3 & $\mathrm{SE}(\mathrm{B})$ & 0.66 & $\mathrm{Y}$ & 50. & 40. & 50. \\
\hline FYO 21 & $\mathrm{SE}(\mathrm{B})$ & 0.14 & $\mathrm{Y}$ & 50. & 40. & 50. \\
\hline FYO 26 & $\mathrm{SE}(\mathrm{B})$ & 0.13 & $\mathrm{Y}$ & 25. & 20. & 50. \\
\hline FYO 27 & $\mathrm{SE}(\mathrm{B})$ & 0.14 & $\mathrm{Y}$ & 25. & 20. & 50. \\
\hline FYO 150 & $\mathrm{SE}(\mathrm{B})$ & 0.61 & $\mathrm{Y}$ & 25. & 20. & 50. \\
\hline FYO 151 & $\mathrm{SE}(\mathrm{B})$ & 0.61 & $\mathrm{Y}$ & 25. & 20. & 50. \\
\hline FYO 158 & $\mathrm{SE}(\mathrm{B})$ & 0.60 & $\mathrm{Y}$ & 12.5 & 10. & 50. \\
\hline FYO 159 & $\mathrm{SE}(\mathrm{B})$ & 0.62 & $\mathrm{Y}$ & 12.5 & 10. & 50. \\
\hline FYO 160 & $\mathrm{SE}(\mathrm{B})$ & 0.11 & $\mathrm{Y}$ & 12.5 & 10. & 50. \\
\hline FYO 161 & $\mathrm{SE}(\mathrm{B})$ & 0.11 & $\mathrm{Y}$ & 12.5 & 10. & 50. \\
\hline FYO 2SB & $\mathrm{SE}(\mathrm{T})$ & 0.40 & $\mathrm{Y}$ & 25. & 20. & 64. \\
\hline FYO 3SB & $\mathrm{SE}(\mathrm{T})$ & 0.47 & $\mathrm{Y}$ & 25. & 20. & 64. \\
\hline FYO 4SA & $\mathrm{SE}(\mathrm{T})$ & 0.65 & $\mathrm{Y}$ & 25. & 20. & 64. \\
\hline FYO 10SA & $\mathrm{SE}(\mathrm{T})$ & 0.35 & $\mathrm{Y}$ & 25. & 20. & 64. \\
\hline FYO 11SB & $\mathrm{DE}(\mathrm{T})$ & 0.68 & $\mathrm{Y}$ & 25. & 20. & 32. \\
\hline FYO 12SA & $\mathrm{DE}(\mathrm{T})$ & 0.61 & $\mathrm{Y}$ & 25. & 20. & 32. \\
\hline
\end{tabular}


Table 3 List of A533B specimens tested in this investigation.

\begin{tabular}{|c|c|c|c|c|c|c||}
\hline Specimen ID & Type & a/W & $\begin{array}{c}\text { Side } \\
\text { Groove? } \\
(\mathrm{Y} / \mathrm{N})\end{array}$ & $\begin{array}{c}\text { B } \\
(\mathrm{mm})\end{array}$ & $\begin{array}{c}\mathrm{B}_{\mathrm{N}} \\
(\mathrm{mm})\end{array}$ & $\begin{array}{c}\mathrm{W} \\
(\mathrm{mm})\end{array}$ \\
\hline $\mathrm{CT} 3$ & $\mathrm{C}(\mathrm{T})$ & 0.6 & $\mathrm{Y}$ & 25. & 20. & 50. \\
\hline CT9 & $\mathrm{C}(\mathrm{T})$ & 0.6 & $\mathrm{Y}$ & 25. & 20. & 50. \\
\hline CT10 & $\mathrm{C}(\mathrm{T})$ & 0.6 & $\mathrm{Y}$ & 25. & 20. & 50. \\
\hline \hline DB1 & $\mathrm{SE}(\mathrm{B})$ & 0.62 & $\mathrm{Y}$ & 25. & 20. & 50. \\
\hline DB2 & $\mathrm{SE}(\mathrm{B})$ & 0.62 & $\mathrm{Y}$ & 25. & 20. & 50. \\
\hline DB3 & $\mathrm{SE}(\mathrm{B})$ & 0.62 & $\mathrm{Y}$ & 25. & 20. & 50. \\
\hline \hline SB1 & $\mathrm{SE}(\mathrm{B})$ & 0.15 & $\mathrm{Y}$ & 25. & 20. & 50. \\
\hline SB2 & $\mathrm{SE}(\mathrm{B})$ & 0.15 & $\mathrm{Y}$ & 25. & 20. & 50. \\
\hline SB3 & $\mathrm{SE}(\mathrm{B})$ & 0.15 & $\mathrm{Y}$ & 25. & 20. & 50. \\
\hline \hline SEN1 & $\mathrm{SE}(\mathrm{T})$ & 0.41 & $\mathrm{Y}$ & 25. & 20. & 63.5 \\
\hline SEN2 & $\mathrm{SE}(\mathrm{T})$ & 0.38 & $\mathrm{Y}$ & 25. & 20. & 63.5 \\
\hline SEN4 & $\mathrm{SE}(\mathrm{T})$ & 0.66 & $\mathrm{Y}$ & 25. & 20. & 63.5 \\
\hline SEN9 & $\mathrm{SE}(\mathrm{T})$ & 0.41 & $\mathrm{Y}$ & 25. & 20. & 63.5 \\
\hline SEN10 & $\mathrm{SE}(\mathrm{T})$ & 0.62 & $\mathrm{Y}$ & 25. & 20. & 63.5 \\
\hline \hline SE5D & $\mathrm{DE}(\mathrm{T})$ & 0.7 & $\mathrm{Y}$ & 25. & 20. & 31.8 \\
\hline SE6D & $\mathrm{DE}(\mathrm{T})$ & 0.7 & $\mathrm{Y}$ & 25. & 20. & 31.8 \\
\hline SE7D & $\mathrm{DE}(\mathrm{T})$ & 0.68 & $\mathrm{Y}$ & 25. & 20. & 31.8 \\
\hline
\end{tabular}


sturdier than usual to accommodate the higher loads typical of short crack specimens. The procedures used for the short crack tests were presented by Joyce (1992) which showed clearly that unloading compliance was a viable test technique for $\mathrm{SE}(\mathrm{B})$ specimens with a/W as short as 0.1 . The compliance equations are much less sensitive in the short crack region, but the load applied increases with $(\mathrm{W}-\mathrm{a})^{2}$ so that for the short crack specimens the unloadings become much larger, and the crack opening displacement (COD) continues to be adequately large and can be measured with a high resolution digital voltmeter. The combination of high loads and less sensitive unloading compliance makes these test more difficult, but if care is taken, excellent results can be obtained. A flex bar was used to measure the load line displacements for all SE(B) specimens as described previously (Hackett and Joyce, 1986) since significant indentations did occur at the rollers for these specimens.

The SE(T) and DE(T) specimens were loaded with oversized tension clevises similar to what is used for standard $\mathrm{C}(\mathrm{T})$ specimens. The HY-100 tests were done with clevises that had round holes while the A533B tests were done with clevises that had flat bottomed holes to allow for the loading pin to roll as the specimen rotated during test. It was found that allowing the specimen half to rotate freely, and correcting for the rotation effects was the preferred method for the $S E(T)$ tests. For DE(T) specimens, however, it was found that round bottom holes were preferred, providing an initial alignment that was essential to accurately test the DE(T) specimen both at the start of test and as crack growth proceeded. For the SE(T) specimens a standard clip gage was installed to measure the crack mouth opening displacement, which was used for crack length estimation, and an LVDT gage was installed on the initial specimen load line to measure the load line extension of the specimen. For the DE(T) specimen, two COD gages were used as well as an LVDT gage on the specimen centerline. In general the average COD displacement was used to estimate the average crack length for the DE(T) specimen. Both COD gage readings were recorded in the data file and can be plotted separately; if desired. 


\subsection{ANALYSIS}

\section{$2.1 \mathrm{~J}$ Integral Analysis}

The $\mathrm{J}$ integral is calculated here by summing the elastic and plastic components, with the components calculated separately. The elastic $\mathrm{J}$ component, $\mathrm{J}_{\mathrm{el}}$, is calculated from:

$$
J_{e l}=\frac{K^{2}}{E^{\prime}}
$$

where $K$ is the elastic stress intensity factor for the specimen, $E^{\prime}=E /\left(1-v^{2}\right)$, and $E$ and $v$ are the elastic modulus and Poisson's ratio, respectively. The plastic $\mathrm{J}$ component, $\mathrm{J}_{\mathrm{pl}}$, is calculated using the ASTM Standard E1152 $\mathrm{J}_{\mathrm{pl}}$ equation:

$$
J_{p l(i)}=J_{p l(i-1)}+\frac{\eta_{i}}{b_{i}}\left[\frac{A_{p l(i)}-A_{p l(i-1)}}{B_{N}}\right]\left[1-\frac{\gamma_{i}\left(a_{i}-a_{(i-1)}\right)}{b_{i}}\right]
$$

with:

$A_{p l i}=$ area under the load versus plastic load line displacement curve to increment $i$, $\mathrm{B}_{\mathrm{N}}=$ net specimen thickness at the side groove roots, $\eta_{i}=$ the plastic $\eta$ factor at crack length $a_{i}$

$\mathrm{b}_{\mathrm{i}}=$ the incremental remaining ligament

$\mathrm{W}=$ the specimen width and

$$
\gamma_{i}=\left[\eta_{i}-1-\frac{b_{i}}{W} \frac{\eta_{i}^{\prime}}{\eta_{i}}\right]
$$

evaluated at the crack length $\mathrm{a}_{\mathrm{i}}$, and:

$$
\eta_{i}^{\prime}=d \eta_{i} / d\left(a_{i} / W\right)
$$

Formulas for the K's, $\eta$ 's, and $\gamma$ 's used for the $\operatorname{SE}(B), \operatorname{SE}(T)$, and $D E(T)$ specimens are presented in the next subsections.

\subsection{SE(B) Analysis}

Previous work by Joyce (1992) has shown that unloading compliance can be used to 
evaluate J-R curves for short crack bend specimens. As the crack becomes very short the compliance equation becomes less sensitive to crack length but the specimen limit load also increases, which increases the length of the allowed elastic unloading, and the total effective crack length measurement resolution is only slightly degraded. Results obtained by Joyce (1992) appeared to be fully adequate for $\mathrm{J}_{\mathrm{Ic}}$ and $\mathrm{J}-\mathrm{R}$ curve testing for $\mathrm{a} / \mathrm{W}$ ratios as small as 0.15 . In this work similar success was found for a/W ratios as small as 0.1 . To test in this a/W range a new equation to estimate crack length from the specimen COD compliance is needed since the equation available in ASTM E813 and E1152 does not apply for a/W ratios below 0.4. An equation for bend specimen compliance as a function of $a / W$ that is good for all $a / W$ is available in The Stress Analysis of Cracks Handbook (The Handbook) (Tada, Paris and Irwin 1985). This equation is:

$$
\frac{8}{P}=\frac{24(a / W)}{\left(\frac{B W E^{\prime}}{S / 4}\right)}\left[0.76-2.28\left(\frac{a}{W}\right)+3.87\left(\frac{a}{W}\right)^{2}-2.04\left(\frac{a}{W}\right)^{3}+\frac{0.66}{(1-a / W)^{2}}\right]
$$

where: $\quad \delta=$ crack mouth opening displacement at the specimen edge

$P=$ load

$\mathrm{B}=$ specimen thickness

$S=$ specimen span

For the short crack range a reverse fit to calculate the crack size, a/W, from the measured compliance was obtained by Joyce (1992) using a standard fifth order polynomial by restricting the $\mathrm{a} / \mathrm{W}$ range to between 0.05 and 0.45 . The fit is accurate to within $0.06 \%$ which is acceptable for the unloading compliance method. The Joyce relationship is:

$$
\begin{gathered}
\frac{a}{W}=1.01878-4.5367 u+9.0101 u^{2}-27.333 u^{3}+74.4 u^{4}-71.489 u^{5} \\
u=\frac{1}{\left(\frac{B_{e} W E^{\prime} C}{S / 4}\right)^{1 / 2}+1}
\end{gathered}
$$

where $C=$ unloading compliance, $\delta / P$, and has been used for the short crack $S E(B)$ specimens presented below. The standard equation of ASTM E1152 was used for the deep cracked bend specimens analyzed below.

For the deep cracked SE(B) specimens the $\eta$ and $\gamma$ factors of ASTM E1152, $(\eta=2.0$ and $\gamma=1.0$ ), are used in Eq. 2 to evaluate J. For the short crack specimens, however, these 
coefficients must be changed to accurately evaluate $\mathrm{J}$. This problem has been investigated by Haigh and Richards (1974), Sumpter (1987), and by Joyce (1992). A comparison of various estimates of $\eta$ is shown in Figure 2 which includes results of the above authors and results derived by Joyce (1992) from Elastic-Plastic Fracture Analysis (EPRI Handbook) (Kumar, German and Shih 1981). The ABAQUS results were obtained by Joyce (1992) using a 2D elastic plastic finite element analysis incorporating incremental plasticity. In the work that follows the polynomial function for $\eta_{i}$ developed by Sumpter (1987) is used for all short cracked SE(B) specimens with $\mathrm{a} / \mathrm{W}<0.282$. This polynomial expression is:

$$
\eta=0.32+12(a / W)-49.5(a / W)^{2}+99.8(a / W)^{3}
$$

This equation gives $\eta<2.0$ for $a / w<0.282$. Sumpter switches to $\eta=2.0$ when the crack length exceeds $a / W=0.282$. In this work the short crack specimens were started and completed with a/W $<0.282$. Equation (7) was used because it was complete in the range of interest and because of the correspondence with the EPRI Handbook results.

The $\gamma$ factor is calculated from $\eta$ using Eq. 3. For the short crack specimens $\gamma$ was obtained by differentiating Eq. (7) to give:

$$
\gamma=\frac{-12.22+106.7\left(\frac{a}{W}\right)-236.6\left(\frac{a}{W}\right)^{2}-924.6\left(\frac{a}{W}\right)^{3}+4845.4\left(\frac{a}{W}\right)^{4}-9880\left(\frac{a}{W}\right)^{5}+9960\left(\frac{a}{W}\right)^{6}}{0.32+12\left(\frac{a}{W}\right)-49.5\left(\frac{a}{W}\right)^{2}+99.8\left(\frac{a}{W}\right)^{3}}
$$

Recent work by Kirk and Dodds (1993) has suggested that J should be calculated using an $\eta_{\text {CoD }}$ based on the crack mouth opening displacement rather than on the load line displacement. Kirk and Dodds show with computational calculations that $\eta_{\text {coD }}$ is much less dependent on strain hardening than is the standard load line $\eta$. The equation used then to calculate $\mathrm{J}$ using $\eta_{\mathrm{COD}}$ is:

$$
J=J_{a l}+\frac{\eta_{C O D} A_{C O D p l(i)}}{b_{i} B_{N}}
$$

where: $\quad A_{\text {CoDp }(i)}=\quad$ area under the load versus plastic crack opening displacement curve to increment $\mathbf{i}$.

This equation does not include the crack growth correction term used in all other equations in this work, and this causes it to have serious problems since the crack growth correction is essential for the development of a correct J-R curve beyond $1 \mathrm{~mm}$ of crack growth. 


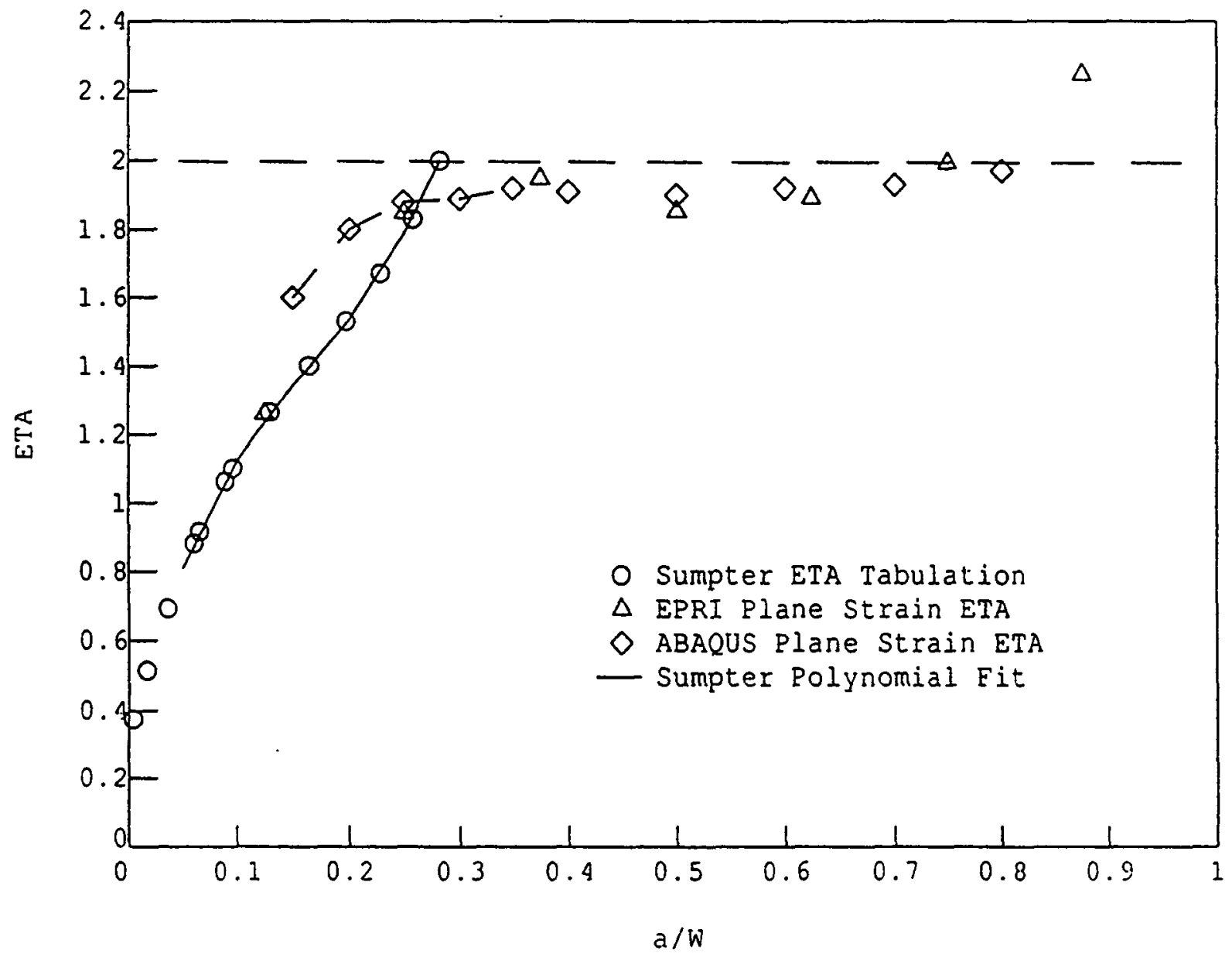

Figure 2 Predicted plastic $\eta$ factors for SE(B) specimens. 


\section{$2.3 \mathrm{SE}(\mathrm{T})$ Analysis}

For unloading compliance testing of SE(T) specimens equations are required for $K, \eta$, and $\gamma$, as functions of $\mathrm{a} / \mathrm{W}$. The equations used in this work are presented in the following sections.

\subsubsection{SE(T) K Expression}

Since the $S E(T)$ specimens tested here had pin loading, the $K$ expressions for fixed end loading in The Handbook were checked with ABAQUS finite element analysis. A total of 14 different $\operatorname{SE}(\mathrm{T})$ finite element grids were developed with $0.12 \leq \mathrm{a} / \mathrm{W} \leq 0.80$. These grids were used to develop both the elastic stress intensity factor $K$ and the plastic $\eta$ factor as described below. The stress intensity factor relationship was assumed to have the form:

$$
K=\sqrt{\pi a} \frac{P}{W B} F\left(\frac{a}{W}\right)
$$

and $F(a / W)$ was fit with a polynomial to give:

$$
\begin{gathered}
F(a / W)=-0.0917+22.392(a / W)-141.96(a / W)^{2}+449.72(a / W)^{3} \\
-645.59(a / W)^{4}+363.52(a / W)^{5}
\end{gathered}
$$

This equation fit the ABAQUS results within $\pm 2 \%$ over the $a / W$ range from 0.12 to 0.80 . A comparison is presented in Figure 3 with the ABAQUS results and a standard form taken from The Handbook. Clearly The Handbook equation, the polynomial fit, and the ABAQUS results agree very well in the range of $0.12 \leq \mathrm{a} / \mathrm{W} \leq 0.80$. In the experimental work presented below the polynomial form for $F(a / W)$ presented in Eq. (10) has been used for all SE(T) specimens.

\subsubsection{SE(T) $\cap$ Factor}

In Joyce, et al. (1992) several methods were used to estimate the $\eta$ for the $\operatorname{SE}(T)$ specimen including elastic-plastic finite elements analysis, the EPRI Handbook, and published results by Wu, et al. (1990) and Sharobeam, et al.(1991). A comparison of all of these results from Joyce, et al. (1992) is shown in Figure 4. 


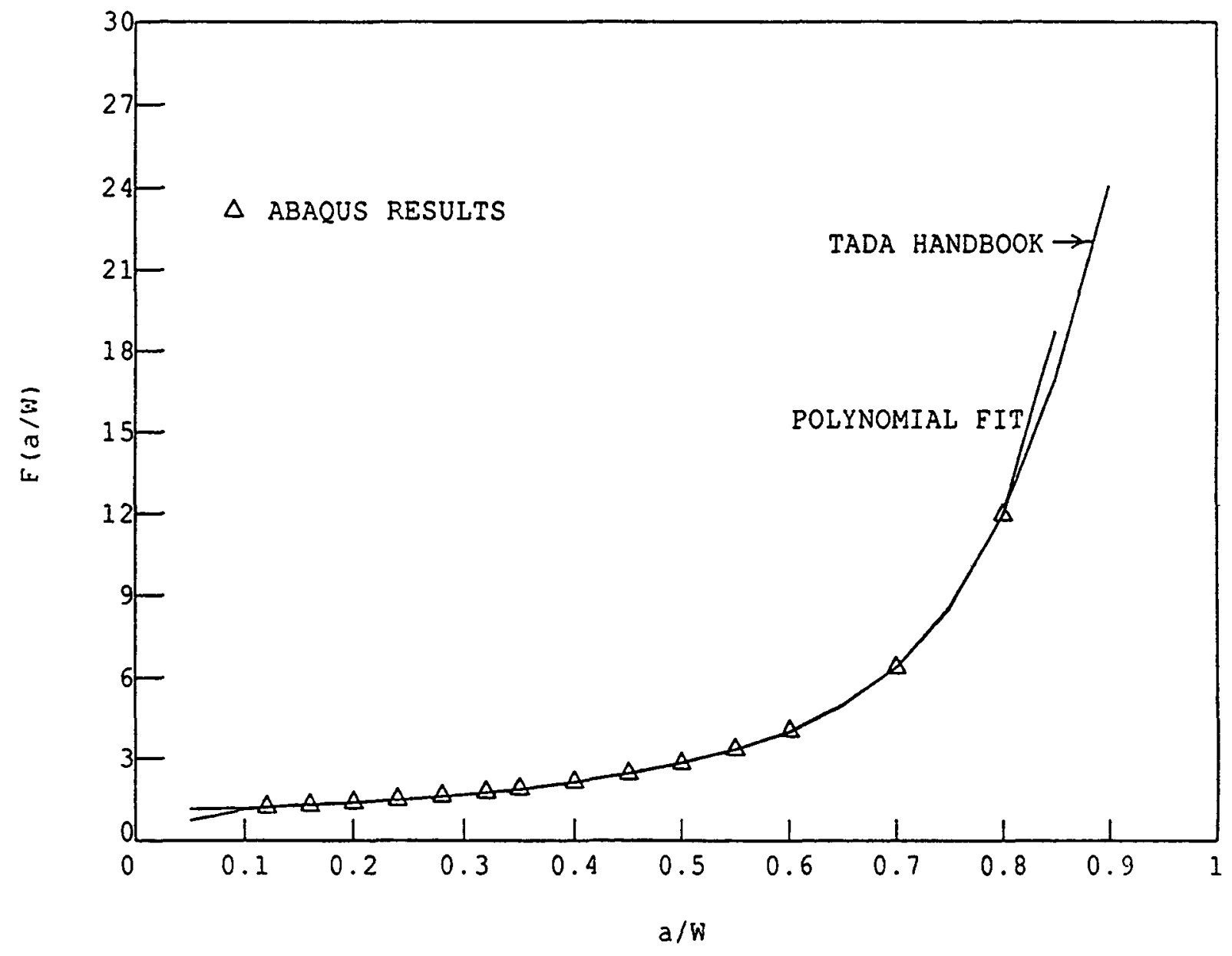

Figure 3 Comparison of stress intensity factor relationships for the SE(T) specimen. 


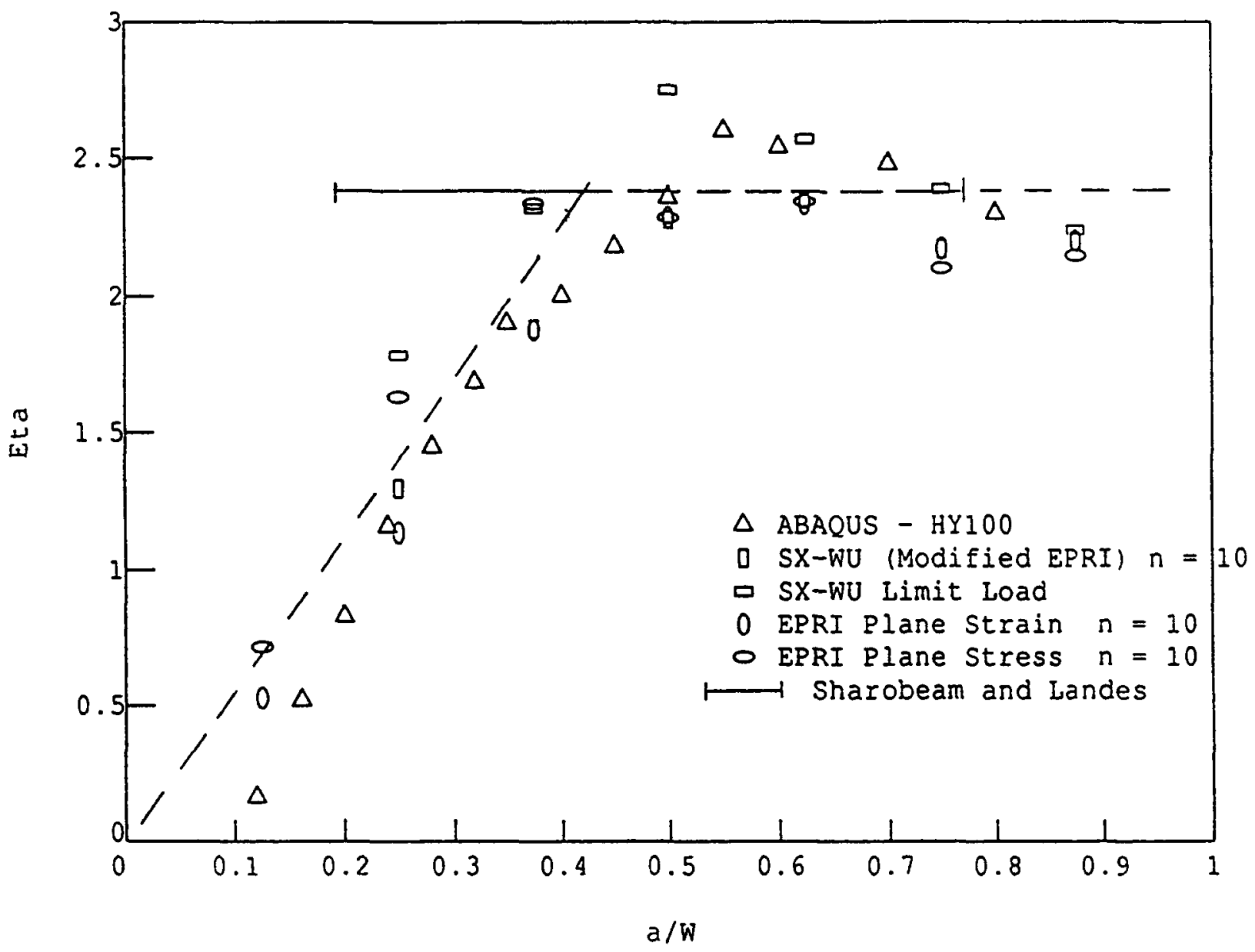

Figure 4 Predicted plastic $\eta$ factors for the SE(T) geometry 
In the experimental work that follows the dashed bi-linear relationship shown in Figure 4 was used to evaluate $\eta_{i}$ at each crack length $a_{i}$. This form also allowed calculating $\gamma_{i}$, from Eq. (3) which is necessary to calculate $J_{p l}$ using Eq. (2). The equations used to evaluate $\eta_{i}$ and $\gamma_{i}$ for the $S E(T)$ specimen are thus:

$$
\begin{array}{cc}
\eta_{i}=5.71\left(a_{i} / W\right) & 0 \leq a_{i} / W \leq 0.417 \\
\eta_{i}=2.38 & 0.417<a_{i} / W \leq 1.0 \\
\gamma_{i}=\eta_{i}-1-\left(b_{i} / W\right)\left(\frac{5.71}{\eta_{i}}\right) & 0<a_{j} / W \leq 0.417 \\
\gamma_{i}=1.38 & 0.417<a_{j} / W \leq 1.0
\end{array}
$$

\subsubsection{SE(T) Crack Length Estimation}

Since the $S E(T)$ specimen is of a rather short length and has the load applied through the centered pin holes, the compliance equations in standard fracture mechanics handbooks like The Handbook are not necessarily applicable. The standard forms available assume uniform stresses at the loading edges and the $\mathrm{SE}(\mathrm{T})$ configuration used here was not thought to be long enough to allow the direct use of equations based on the uniform stress assumption. A finite element analysis was used in Joyce, et al. (1992) to develop a polynomial equation giving the crack length as a function of the COD compliance for the $\operatorname{SE}(T)$ specimen geometry used here. This equation has the form:

$$
\begin{array}{r}
a / W=1.012525-2.95323(u)^{1}+6.68(u)^{2}-17.7954(u\}^{3} \\
+25.3517(u)^{4}-12.9747(u)^{5}
\end{array}
$$

with:

$$
u^{\prime}=\frac{1}{1+\sqrt{\frac{E^{\prime} B \delta}{P}}}
$$


For side grooved specimens the thickness $B$ is replaced by $B_{e}$ where:

$$
B_{e}=B-\frac{\left(B-B_{n}\right)^{2}}{B}
$$

where $B_{n}$ is the net specimen thickness at the side groove roots. This effective thickness formulation is consistent with ASTM E813 and E1152. 


\subsubsection{SE(T) Rotation Correction}

A rotation correction can be developed for the $S E(T)$ specimen using the notation of Figure 5. Two separate corrections are needed, one to correct the knife edge COD displacement for the effect of rotation, the second to correct the load for the effect of rotation.

The objective of the first correction is to correct the measured displacement $\mathrm{d}_{\mathrm{m} / 2}$ to obtain the correct displacement $d_{c / 2}$, as shown in Figure 5a. Using the geometry of Figure 5a gives:

$$
\frac{d_{c / 2}+D}{R_{G}}=\tan \left(\theta+\tan ^{-1} \frac{D}{R_{G}}\right)
$$

and using the standard trigonometry identity for $\tan (x+y)$ and eliminating small terms gives:

$$
d_{c / 2}=R_{G} \tan \theta
$$

where:

$$
\theta=\sin ^{-1}\left[\frac{\left(d_{m / 2}+D\right)}{\left(D^{2}+R_{G}^{2}\right)^{1 / 2}}\right]-\tan ^{-1} \frac{D}{R_{G}}
$$

Similarly from Figure 5a:

$$
\frac{d_{m p}+D}{\sqrt{\left(D^{2}+R_{G}^{2}\right)}}=\sin \left(\theta+\tan ^{-1} \frac{D}{R_{G}}\right)
$$

and again using the standard identity for $\sin (x+y)$ and eliminating small terms gives:

$$
d_{m / 2}=R_{G} \sin \theta+D \cos \theta-D
$$

and the desired displacement correction factor can then be written as:

$$
\frac{d_{c / 2}}{d_{m / 2}}=\frac{R_{G} \tan \theta}{R_{G} \sin \theta+D \cos \theta-D}
$$

or as:

$$
\frac{d_{c / 2}}{d_{m / 2}}=\frac{1}{\left(\cos \theta-\frac{D \tan \theta}{2 R_{G}}\right)}
$$



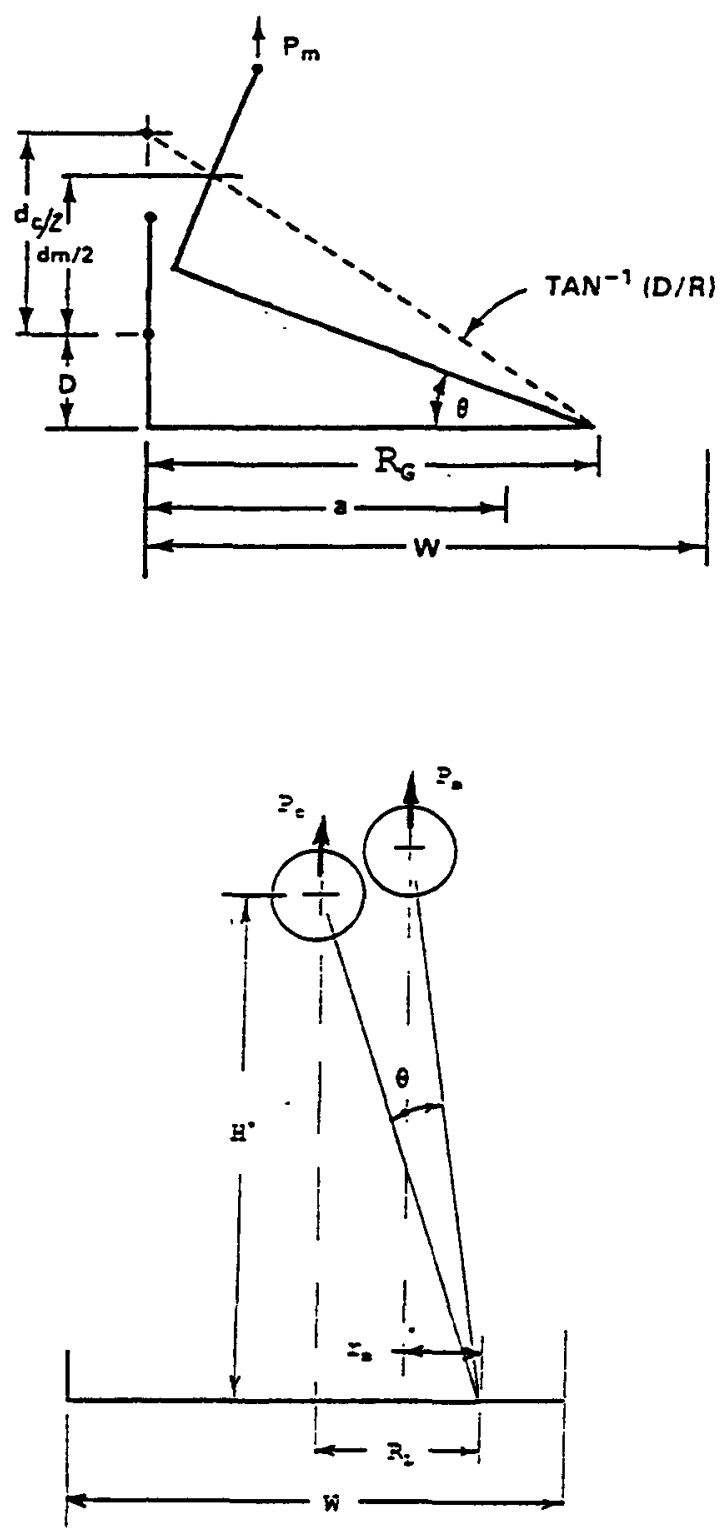

Figure 5 Geometric relationship of variables used in rotation correction development. 
The load rotation correction is obtained by requiring:

$$
P_{c} R_{L}=P_{m} R_{m}
$$

where $P_{m}$ is the measured load and $P_{c}$ is the corrected load. From Figure 5b,

$$
\boldsymbol{R}_{m}=R_{L} \cos \theta-H^{*} \sin \theta
$$

Substituting and reducing gives:

$$
\frac{P_{c}}{P_{m}}=\left(\cos \theta-\frac{H^{*} \sin \theta}{R_{L}}\right)
$$

Combining these correction factors gives:

$$
C_{c}=\frac{C_{m}}{\left(\cos \theta-\frac{D \tan \theta}{2 R_{G}}\right)\left(\cos \theta-\frac{H^{*} \sin \theta}{R_{L}}\right)}
$$

This equation was used to correct the measured compliance $C_{m}$ to obtain the corrected compliance $\mathrm{C}_{\mathrm{c}}$ before calculation of the estimated crack length for the partial unloading.

It was also necessary to apply a rotation correction to the load line compliance so that accurate separation of the measured $\mathrm{J}$ into elastic and plastic components was possible. This correction is effectively just the load component of the COD correction of Eq. 29 giving:

$$
C_{L L D c}=\frac{C_{L L D m}}{\left(\cos \theta-\frac{H^{*} \sin \theta}{R_{L}}\right)}
$$

This equation was used to correct the measured load line compliance $C_{L L D m}$ to obtain the corrected load line compliance, $\mathrm{C}_{\mathrm{LD}}$, before calculating the elastic and plastic area components used to calculated the elastic and plastic $\mathrm{J}$ components.

To use this analysis it is necessary to assume a position for the center of rotation for the $\mathrm{SE}(\mathrm{T})$ specimen. In the standard C(T) analysis of ASTM E1152 the center of rotation is assumed to be at the center of the remaining ligament, and that assumption was also used here, i.e. $R_{G}=$ $(a+W) / 2$ and $R_{L}=R_{G}-W / 2$. 


\subsection{DE(T) Analysis}

For unloading compliance testing of the $\mathrm{DE}(\mathrm{T})$ specimens, equations are required for calculation of $\mathrm{K}, \eta$, and $\gamma$ as functions of $\mathrm{a} / \mathrm{W}$ and for $\mathrm{a} / \mathrm{W}$ as a function of the COD compliance, $\delta / P$. The equations used for this project are presented in the following sections.

\subsubsection{DE(T) K Expression}

The $\mathrm{K}$ equation for the $\mathrm{DE}(\mathrm{T})$ specimen with a deeply cracked geometry can be taken directly from The Handbook. The equation used has the form:

$$
K=\sqrt{\pi a}\left[\frac{P}{2 W B}\right] F(a / W)
$$

with:

$$
F(a / W)=\frac{1.122-0.561\left(\frac{a}{W}\right)+0.205\left(\frac{a}{W}\right)^{2}+0.471\left(\frac{a}{W}\right)^{3}-0.19\left(\frac{a}{W}\right)^{4}}{\sqrt{1-a / W}}
$$

This equation should be accurate to $\pm 0.5 \%$ for any $\mathrm{a} / \mathrm{W}$, but is limited to $\mathrm{a} / \mathrm{W}>0.6$ by the pin hole loading. Three finite element computations by Joyce et al.(1992) showed that this equation is accurate within $\pm 2 \%$ for deeply cracked $D E(T)$ specimens including the center pin holes.

\subsubsection{DE(T) $n$ and $\gamma$ Factors}

The $\eta$ factor for the $\mathrm{DE}(\mathrm{T})$ specimen geometry was obtained from both elastic-plastic finite element analysis using ABAQUS and from the EPRI Handbook. The $\eta$ factor used here is taken to relate the $\mathrm{J}$ integral at each crack to the total plastic work applied to the specimen, i.e.:

$$
J_{p l}=\frac{\eta A_{p l}}{B b}
$$

where:

$\mathrm{A}_{\mathrm{pl}}=$ plastic area under the specimen load versus plastic load line displacement plot

$\mathrm{b}=$ specimen half remaining ligament

$\mathrm{B}=$ specimen thickness

$\eta=$ plastic $\eta$ factor.

Analytical work by $\mathrm{Wu}$, et al. (1990) based on limit load theory, shows that $\eta$ should be 
nearly constant for the $\mathrm{DE}(\mathrm{T})$ specimen over the $\mathrm{a} / \mathrm{W}$ range of interest here. A value of approximately 0.27 , instead of the usual 2.0 , is also predicted in Wu, et al. (1990) with only a very slight dependence on strain hardening. These predictions are confirmed here by both the finite element analysis and the EPRI analysis.

Deeply notched $\mathrm{DE}(\mathrm{T})$ specimens with three different crack sizes were analyzed using finite elements and the results shown in Figure 6, compared to the results of Wu, et al. (1990) Other results shown on Figure 6 include calculations from the EPRI Handbook. The agreement is excellent.

For the experimental work described below a constant value of $\eta$ was used for all tests. $\mathrm{DE}(\mathrm{T})$ specimens were restricted to $0.6 \leq \mathrm{a} / \mathrm{W} \leq 0.9$ and for all tests $\eta$ was set equal to 0.27 while $\gamma$ was taken as $(\eta-1)$ or -0.73 . The negative $\gamma$ did not have a strong effect on these tests because of the small amount of crack extension investigated using the $D E(T)$ specimens.

\subsubsection{DE(T) Crack Length Estimation}

The $\mathrm{DE}(\mathrm{T})$ specimen is tested with a small remaining ligament, generally in the range of $0.6 \leq \mathrm{a} / \mathrm{W} \leq 0.9$. In this range The Handbook compliance equation would be very accurate even for the pin loaded specimen used here. The compliance equation used has the form:

$$
\delta / P=\frac{24 a}{E^{\prime}} \frac{V(a / W)}{W B}
$$

with:

$$
V(a / W)=\frac{1}{u^{*}}\left\{0.454 \sin u^{*}-0.065 \sin ^{3} u^{*}-0.007 \sin ^{5} u^{*}+\cosh ^{-1}\left[\sec \left(u^{*}\right)\right]\right\}
$$

where:

$$
u^{*}=\frac{\pi a}{2 W}
$$

This equation must be inverted to be used for unloading compliance. This inversion can be performed in a standard fashion to give a polynomial compliance equation of the form:

$$
\begin{aligned}
a / W=0.0955026-0.097503 v^{\prime} & +0.245981(v)^{2}-0.115274(v)^{3} \\
& +0.0205763(v)^{4}-0.0013593(v)^{5}
\end{aligned}
$$

with:

$$
v^{\prime}=\frac{E^{\prime} B \boldsymbol{\delta}}{P}
$$




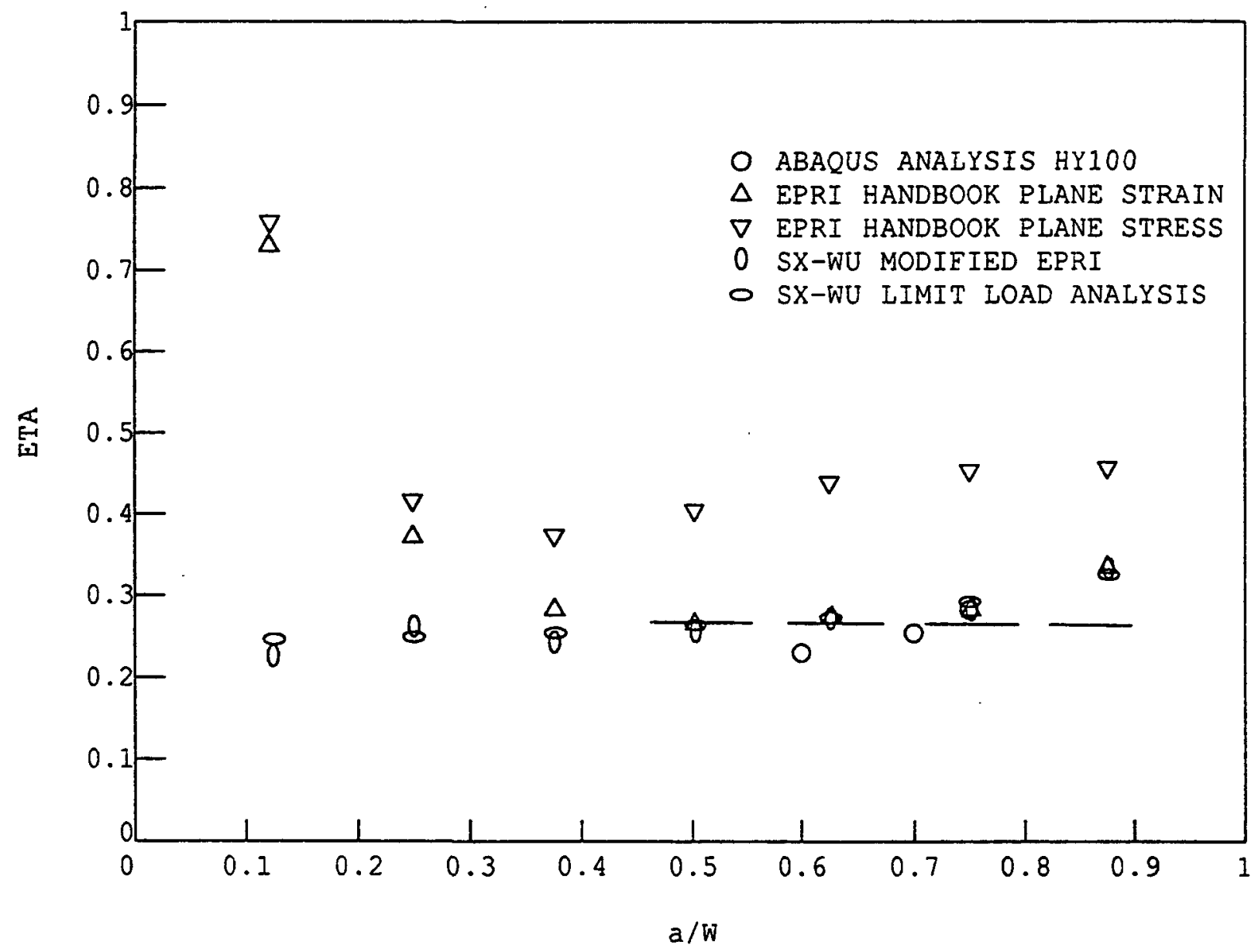

Figure 6 Predicted plastic $\eta$ factors for the $D E(T)$ specimen. 


\subsection{Constraint Correlations}

Recently two quantities have been proposed to quantify the "constraint" present for a given combination of crack geometry, mode of loading, and material toughness. These are the "T-stress" approach (Betégon and Hancock 1992, Al-Ani and Hancock 1991) and the Q parameter of O'Dowd and Shih $(1991,1992)$. These two quantities are described and utilized separately in the next two subsections.

\subsubsection{T Stress Indexing Parameter}

The linear elastic crack tip stress field for a crack along the negative $\mathrm{x}$-axis, with its tip at the origin, has the form:

$$
\begin{gathered}
\sigma_{x x}=\frac{K}{\sqrt{2 \pi r}} f_{x x}(\theta)+T_{\sigma} \\
\sigma_{y y}=\frac{K}{\sqrt{2 \pi r}} f_{y y}(\theta) \\
\sigma_{x y}=\frac{K}{\sqrt{2 \pi r}} f_{x y}(\theta)
\end{gathered}
$$

where the $\mathrm{T}_{\sigma}$ term is the only term of order $\mathrm{r}^{0}$ that exists, and it only affects $\sigma_{\mathrm{xx}}$. Larsson and Carlsson (1973) showed that the sign and magnitude of this term does alter the size and shape of the plastic zone, and recently Betegón and Hancock (1992) and Al-Ani and Hancock (1991) have suggested that the amplitude of the $T_{v}$ term may be an effective constraint indexing parameter, even in the elastic-plastic regime. They show that low constraint geometries like short crack or tensilely loaded geometries have different $T_{\sigma}$ values than deep cracked bend geometries, and they suggest that the $T_{\sigma}$ difference causes higher apparent toughnesses to be found in such cases.

To assess the effect of $T_{\sigma}$, a biaxiality parameter is used having the form

$$
\beta=T_{0} \frac{\sqrt{\pi a}}{K}
$$

This quantity has been evaluated for various test geometries using finite element and other methods and is available in the literature (Leevers and Radon 1982, Kfouri 1986, Sham 1991). Results for $\mathrm{SE}(\mathrm{B}), \mathrm{SE}(\mathrm{T})$, and $\mathrm{DE}(\mathrm{T})$ specimens are shown in Figure 7. For convenience, this data has been used to develop polynomial relationships giving $\beta$ in terms of $a / W$ : 


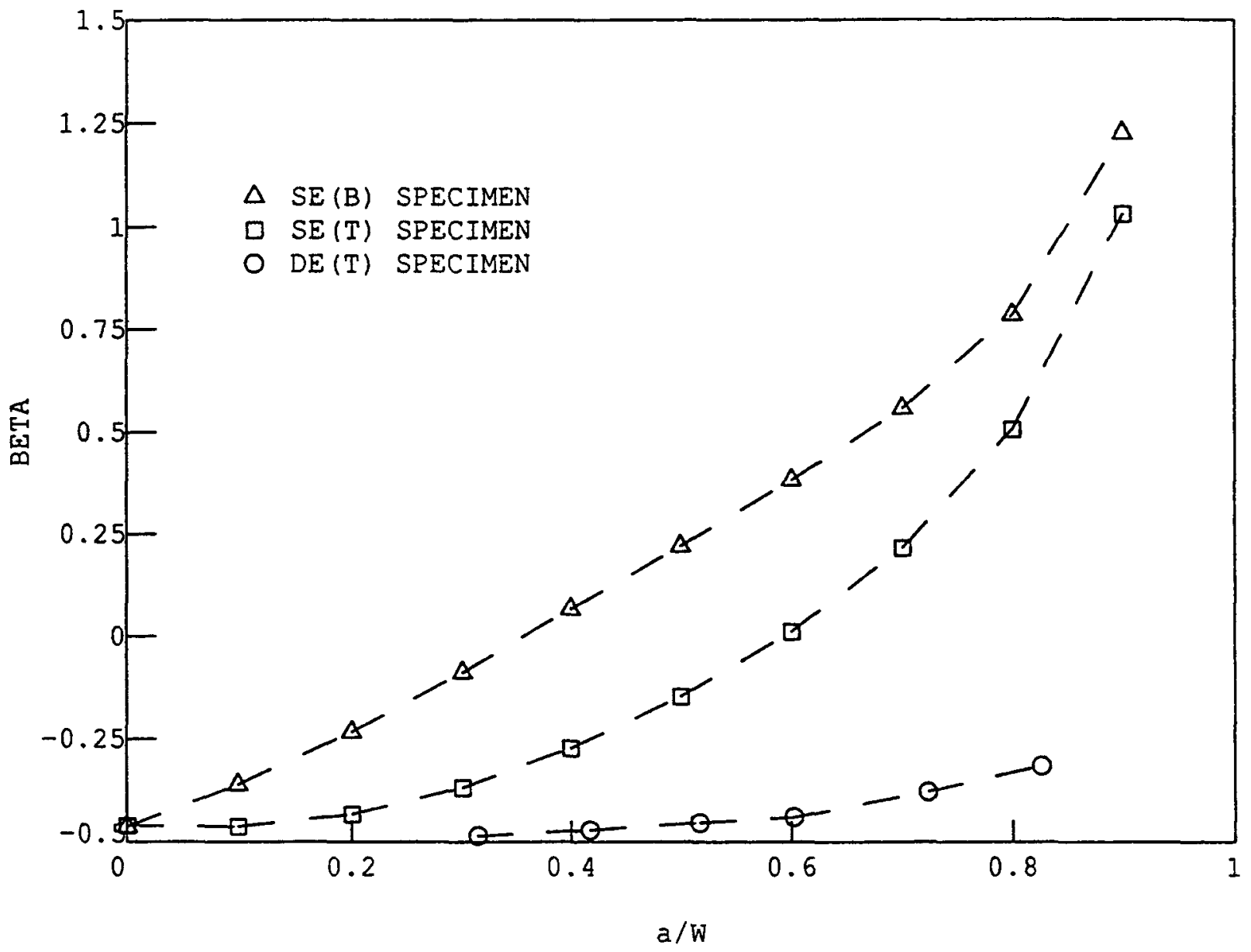

Figure 7 Biaxiality factor, $\beta$, for three specimen geometries. 
SE(B):

$$
\begin{aligned}
\beta=-0.463+1.1207\left(\frac{a}{W}\right) & -1.4441\left(\frac{a}{W}\right)^{2}+11.264\left(\frac{a}{W}\right)^{3} \\
& -20.950\left(\frac{a}{W}\right)^{4}+12.5\left(\frac{a}{W}\right)^{5}
\end{aligned}
$$

SE(T):

$$
\begin{aligned}
\beta=-0.463+0.1012\left(\frac{a}{W}\right) & -1.6844\left(\frac{a}{W}\right)^{2}+13.344\left(\frac{a}{W}\right)^{3} \\
& -21.926\left(\frac{a}{W}\right)^{4}+12.5641\left(\frac{a}{W}\right)^{5}
\end{aligned}
$$

$\mathrm{DE}(\mathrm{T})$ :

$$
\beta=-0.5844+0.6249\left(\frac{a}{W}\right)-1.3527\left(\frac{a}{W}\right)^{2}+1.2031\left(\frac{a}{W}\right)^{3}
$$

Using these relationships the value of $\beta$ for each test geometry in this study has been calculated as shown below. Using the relationships for $\mathrm{K}$ as a function of load and a/W the $T_{\sigma}$ value at the crack initiation $\left(\mathrm{J}_{\mathrm{Ic}}\right)$ point, has also been evaluated for each specimen tested. These results will be discussed in subsequent sections.

\subsubsection{The $Q$ Indexing Parameter}

The Q parameter has been proposed by O'Dowd and Shih $(1991,1992)$ as an extension of the $T_{\sigma}$ concept to deformation plasticity. They take the second term of the stress fields around the crack tip in a power law hardening material and propose that its intensity can be represented by a $Q$ parameter, and that this parameter can be used to index the relative constraint of a test geometry. The authors basically relate the "true" finite body stress components in front of the crack to those of the small scale yielding (SSY), infinite body case in the form:

$$
\begin{gathered}
\sigma_{x x}=\sigma_{x x} l_{s S Y}+Q \sigma_{0} \\
\sigma_{y y}=\sigma_{y y} l_{s S Y}+Q \sigma_{0} \\
\sigma_{x y}=\sigma_{x y} l_{s S Y}
\end{gathered}
$$

where $\sigma_{0}$ is the power law material yield stress and $Q$ is a dimensionless parameter found by O'Dowd and Shih to be between 0.2 and -2 , in front of the crack. Q must be evaluated using precise finite element techniques so that the differences between the true stress field and the SSY stress field can be accurately determined. Results for $Q$ for the SE(B) geometry from O'Dowd and Shih (1992) for the case of $n=10$ are shown in Figure 8, and used to estimate $Q$ values for 

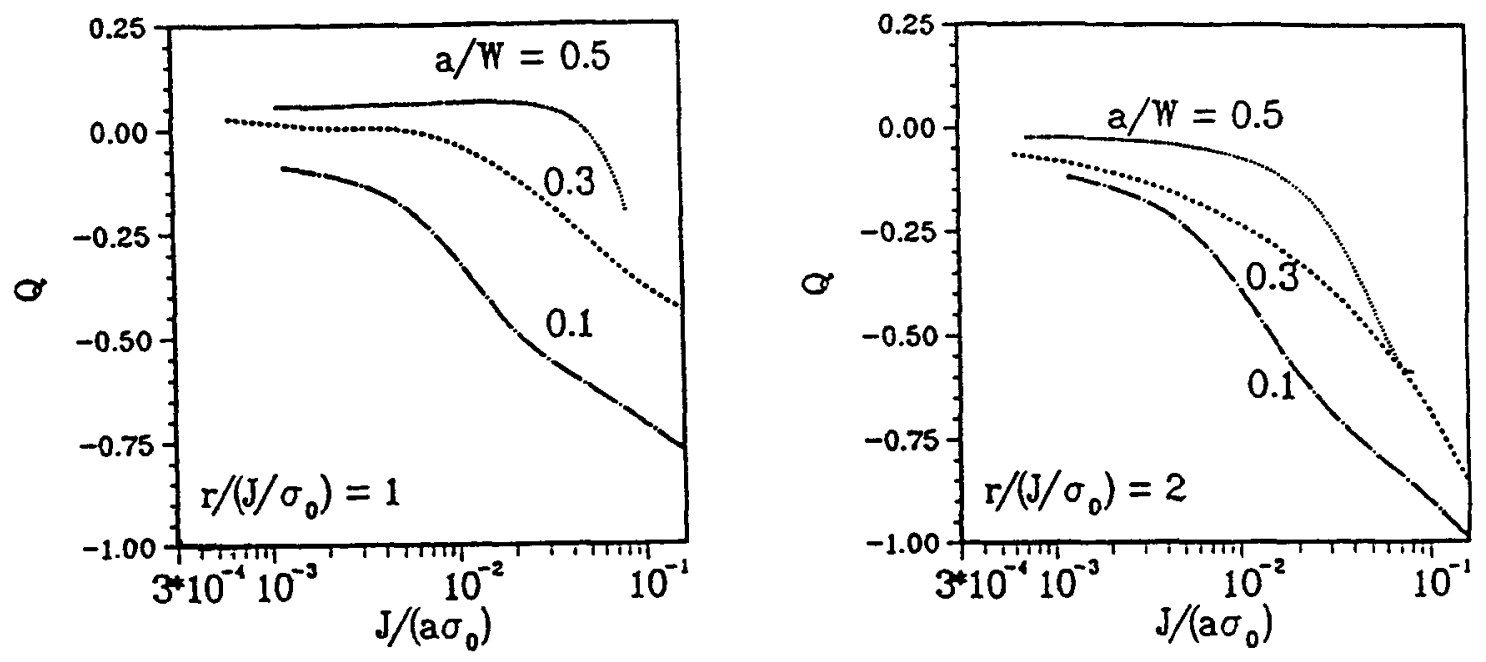

Figure 8 The $Q$ constraint factor for $S E(B)$ specimens with short and deep cracks, $n=10$ (O'Dowd and Shih, 1992). 
the $S E(B)$ specimens tested in this program. $Q$ values for the $S E(T)$ and $D E(T)$ specimens have been obtained from analysis provided by Dodds ${ }^{1}$ as shown in Figure 9-11 for two SE(T) and one $\mathrm{DE}(\mathrm{T})$ geometry.

\subsection{Calculation of $\mathrm{J}_{\mathrm{Tc}}$}

In order to compare $\mathrm{J}_{\mathrm{Ic}}$ across a range of specimen types, special care had to be taken in its evaluation. The $J_{I c}$ value calculated is dramatically affected by the initial crack length, $a_{0}$, used to calculate the crack extension, $\Delta \mathrm{a}$, during the test. The ASTM Task Group E8.08.03 has proposed a method to utilize the initial test data to determine a best $\mathrm{a}_{0}$ for use in calculating $\Delta \mathrm{a}$ and hence in $\mathrm{J}_{\mathrm{Ic}}$ calculations ${ }^{2}$. The proposed method involves fitting a straight line of slope $2 \sigma_{\mathrm{Y}}$ to the initial $\mathrm{J}-\Delta \mathrm{a}$ data, and choosing the best fit line to the data in the interval $0.2 \mathrm{~J}_{\mathrm{Q}} \leq \mathrm{J} \leq$ $0.6 \mathrm{~J}_{Q}$. Since the choice of $\mathrm{a}_{\mathrm{o}}$ affects the subsequent $\mathrm{J}_{\mathrm{Q}}$ value, an iterative process is necessary to obtain the final best fit $a_{o}, J_{Q}$, and hence a $J_{I c}$ value from a particular experimental data set. The proposed method also adds the requirement that at least three data pairs exist in the region $0.2 \mathrm{~J}_{\mathrm{Q}} \leq \mathrm{J} \leq 0.6 \mathrm{~J}_{\mathrm{Q}}$ so relatively dense data is required for $\mathrm{a}_{\mathrm{o}}$ and $\mathrm{J}_{\mathrm{Ic}}$ evaluation.

This method was initially used in this program, but it was found that the method disqualified some specimens due to a lack of data in the region $0.2 \mathrm{~J}_{\mathrm{Q}} \leq \mathrm{J} \leq 0.6 \mathrm{~J} \mathrm{~J}_{\mathrm{Q}}$. In place of the above ASTM method an alternative method was developed that was not so dependent on the early data on the J-R curve. In this method the relationship:

$$
a_{i}=a_{0}+A J_{i}^{2}+B J_{i}^{3}
$$

was fit to the $a_{i}-J_{i}$ data of each set from the minimum $a_{i}$ to $a_{i}+2.5 \mathrm{~mm}$ of crack growth, as shown in Figure 12. A least squares procedure was used to evaluate the coefficients $a_{0}, A$, and $B$, and the $a_{0}$ parameter was the desired, best-fit, initial crack length which was then used to calculate the $\Delta \mathrm{a}_{\mathrm{i}}$ quantities for the J-R curve. This method worked well on all specimens analyzed here and in all cases adequate data was available for the fit, no iteration was needed, and the least squares technique gave a unique and fully defined average crack length for each specimen, while the proposed ASTM method gives only a range from which each investigator could chose a somewhat different result based on the details of his iteration procedure.

${ }^{1}$ Private communication, R.H. Dodds, Jr. 1993.

2 "New Standard Method for J-Integral Characterization of Fracture Toughness," Draft Standard of ASTM Subcommittee E08.08, March 1993, American Society for Testing and Materials, Philadelphia, PA. 


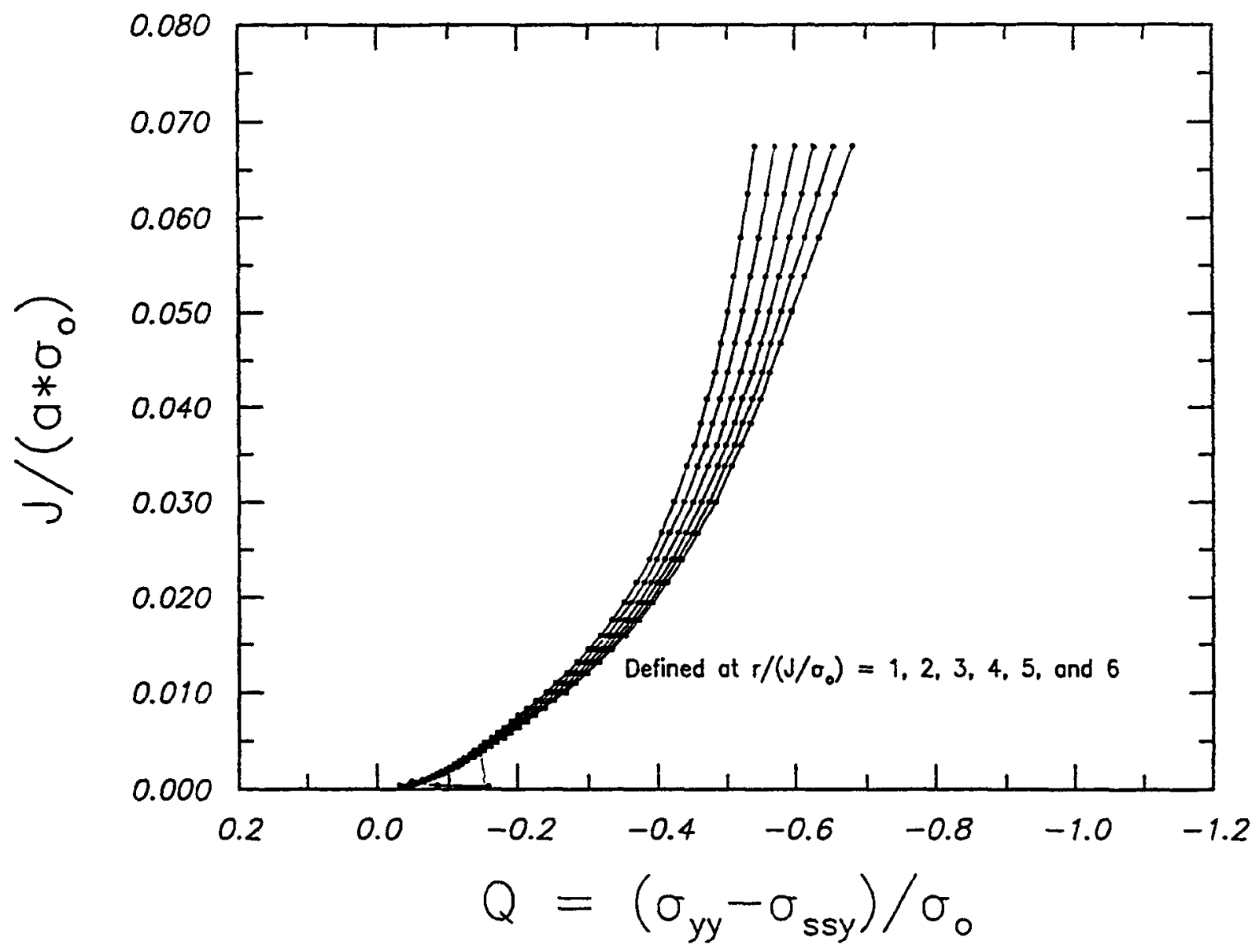

Figure 9 The $Q$ constraint parameter for the $S E(T)$ specimen with $a / W=0.4, n=10$ (R.H. Dodds, Private Communication). 


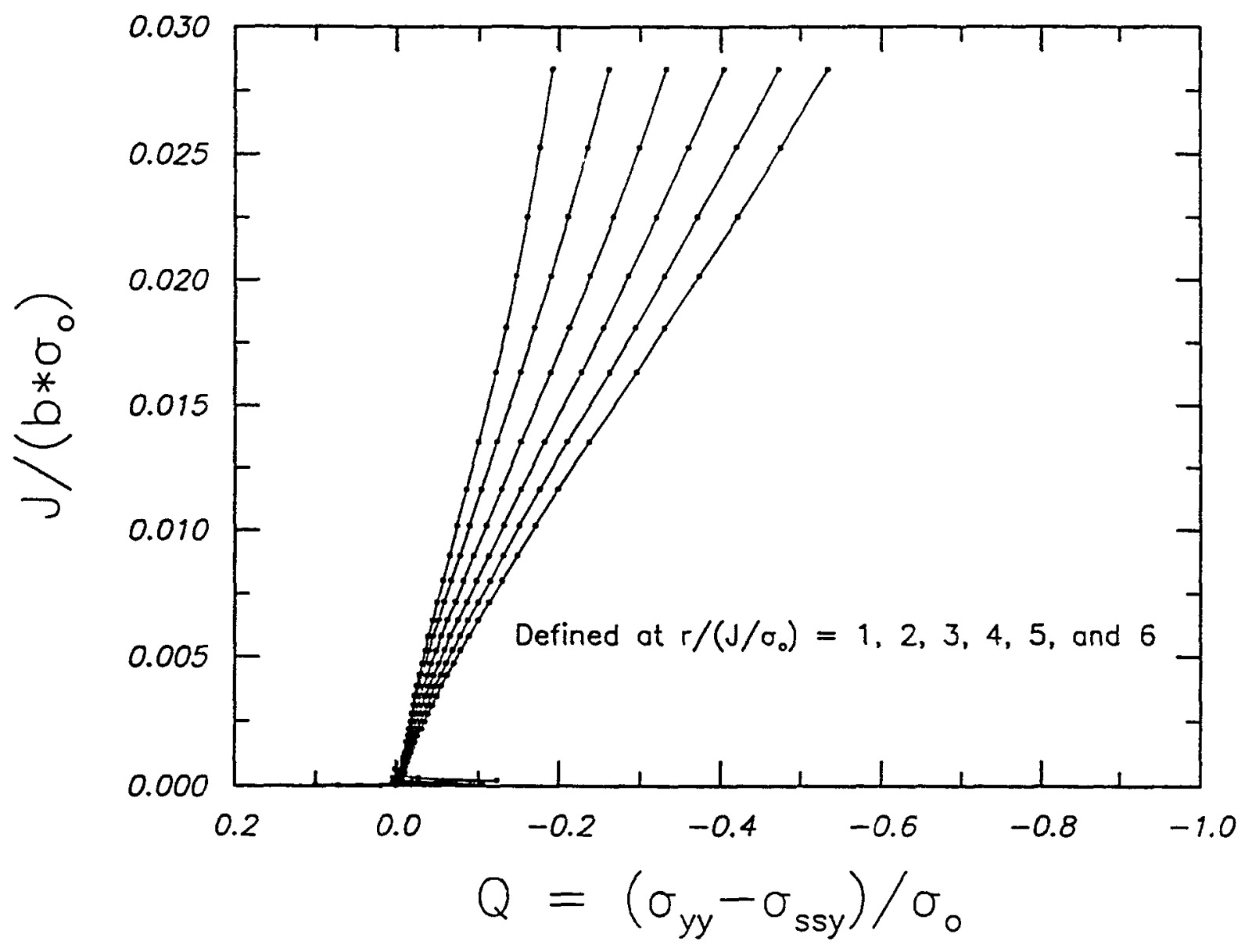

Figure 10 The $Q$ constraint parameter for the $S E(T)$ specimen, a/ $W=0.6, n=10$ (R.H. Dodds, Private communication). 


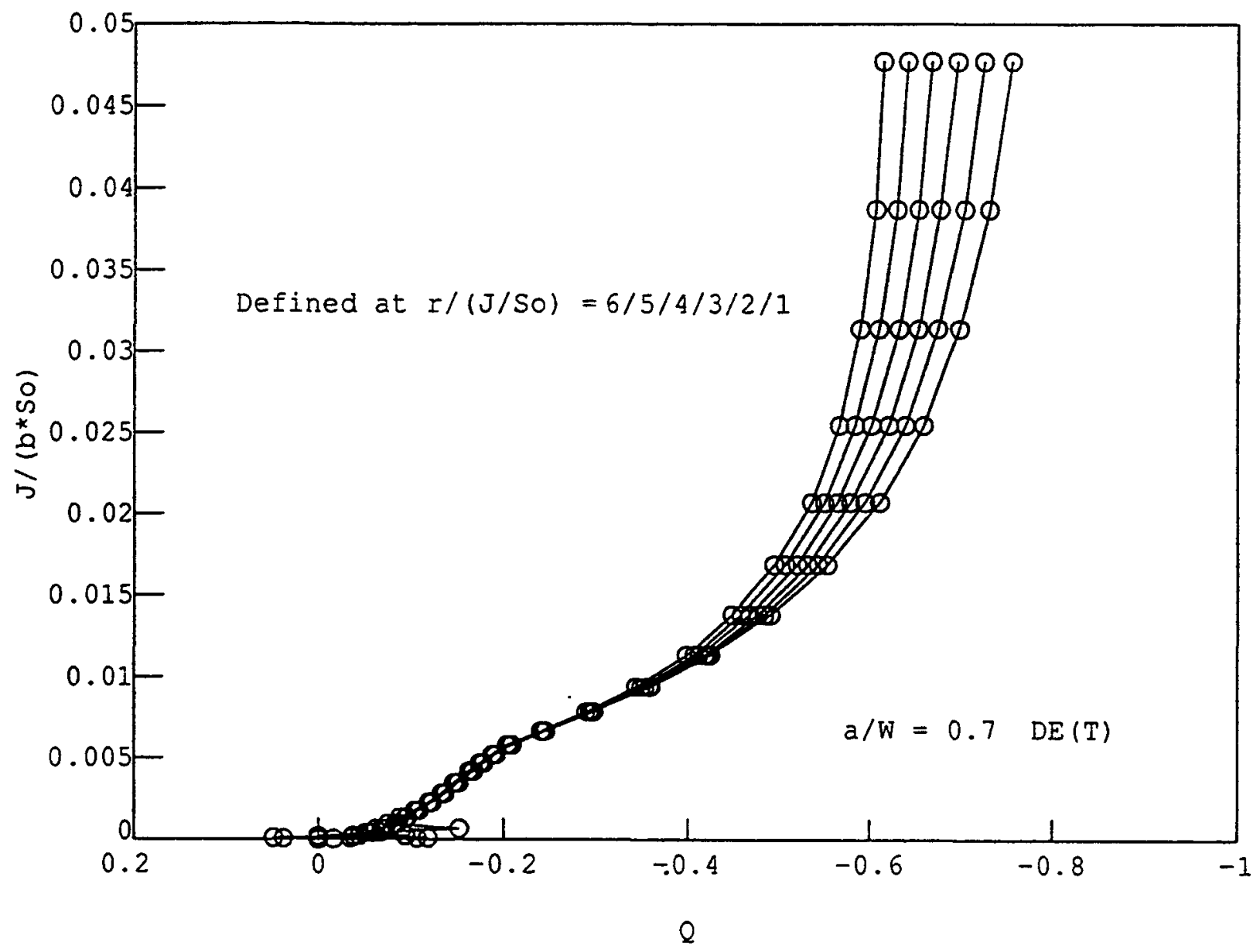

Figure 11 The $Q$ constraint parameter for the $D E(T)$ specimen with $a / W=0.7, n=10$ (R.H. Dodds, Private communication). 


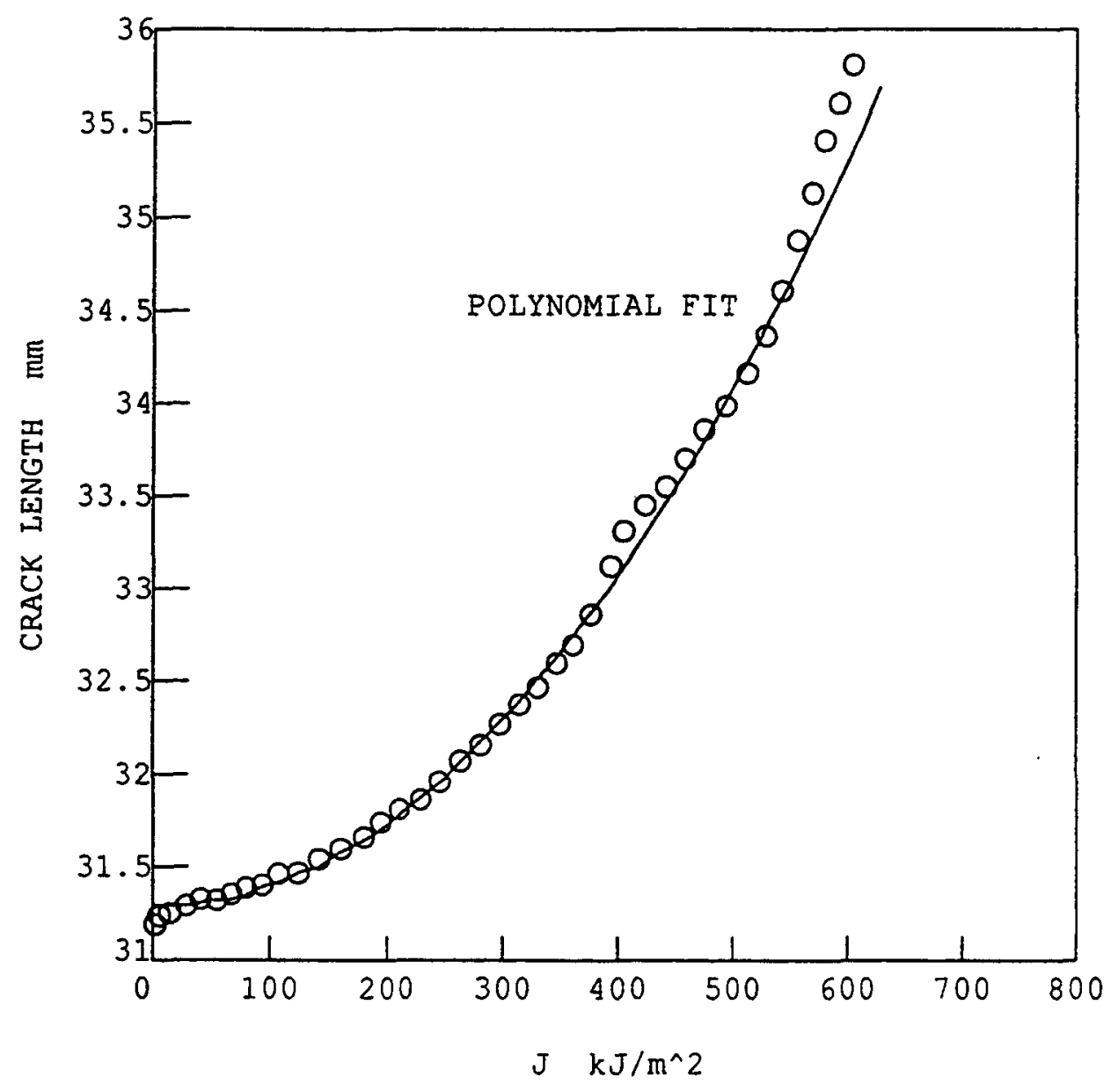

Figure 12 Polynomial fit of crack length versus $J$ for determining the best-fit initial crack length, $a_{0}$. 


\subsection{DISCUSSION}

\subsection{The Rotation Correction}

The SE(T) specimens were a new geometry and problems were encountered in developing test procedures for this geometry. One obstinate problem encountered in testing this geometry was the initial hook, or "crack backup" observed in the J-R curve obtained from these specimens as shown in Figure 13. The unloading compliance measurements show a clear increase in specimen stiffness as one brings up the load on these specimens, both in the elastic and the elastic-plastic regimes. This problem was initially assumed to result from the round hole clevises that were used for the first tests of HY-100 (FYO). New clevises were machined with flat bottomed holes and hardened to allow a free rotation of the specimen halves during the test. This change did not improve the results; however, and it was then that a rotation correction was proposed as a possible solution. The rotation correction was developed, as detailed in Section 2.3.4, in a fashion similar to that used in ASTM E1152 for the C(T) specimen.

The effect of the rotation correction was to remove the initial crack backup without making much of a change in the remainder of the J-R curve, as shown in two examples in Figure 14 and Figure 15 The most dramatic effect is at the start of the J-R curve where the apparent initial stiffening of the specimen is corrected to show an improved resistance curve, especially in the initial portion, which improved the consistency of the calculated $\mathrm{J}_{\mathrm{Ic}}$ results.

The resistance curve slope, $T_{\text {mat }}$ measured at $1 \mathrm{~mm}$ of crack growth, was not found to be changed markedly by the application of the rotation correction, being beyond where most of the effects of the rotation correction was felt.

\section{$\underline{3.2 \mathrm{~J}_{\mathrm{Ic}} \text { and } \mathrm{T}_{\mathrm{mac}} \text { Effects }}$}

$\mathrm{J}_{\mathrm{yc}}$ was calculated for all specimens included in this study using the polynomial relationship - least squares fit approach described above to determine the initial crack length, $a_{0}$. The results for both materials are shown in Table 4 and Table 5, and plotted as a function of specimen type in Figure 16 and Figure 17. $\mathrm{J}_{\mathrm{Ic}}$ does not appear, from these plots, to be very sensitive to the specimen type, at least compared to the large variability demonstrated by each specimen type taken individually.

The material tearing resistance, $T_{\text {mat, }}$ introduced by Paris, et al. (1979), was also evaluated for these specimens:

$$
T_{\operatorname{mat}}=\frac{\sigma_{y}^{2}}{E} \frac{d J}{d a}
$$

where $\sigma_{\mathrm{y}}$ is the material yield stress and $\mathrm{d} J / \mathrm{da}$ is evaluated by fitting a two parameter power law, as used to evaluated $\mathrm{J}_{\mathrm{Ic}}$, to the J-R curve data in the standard ASTM E813 exclusion zone, and 


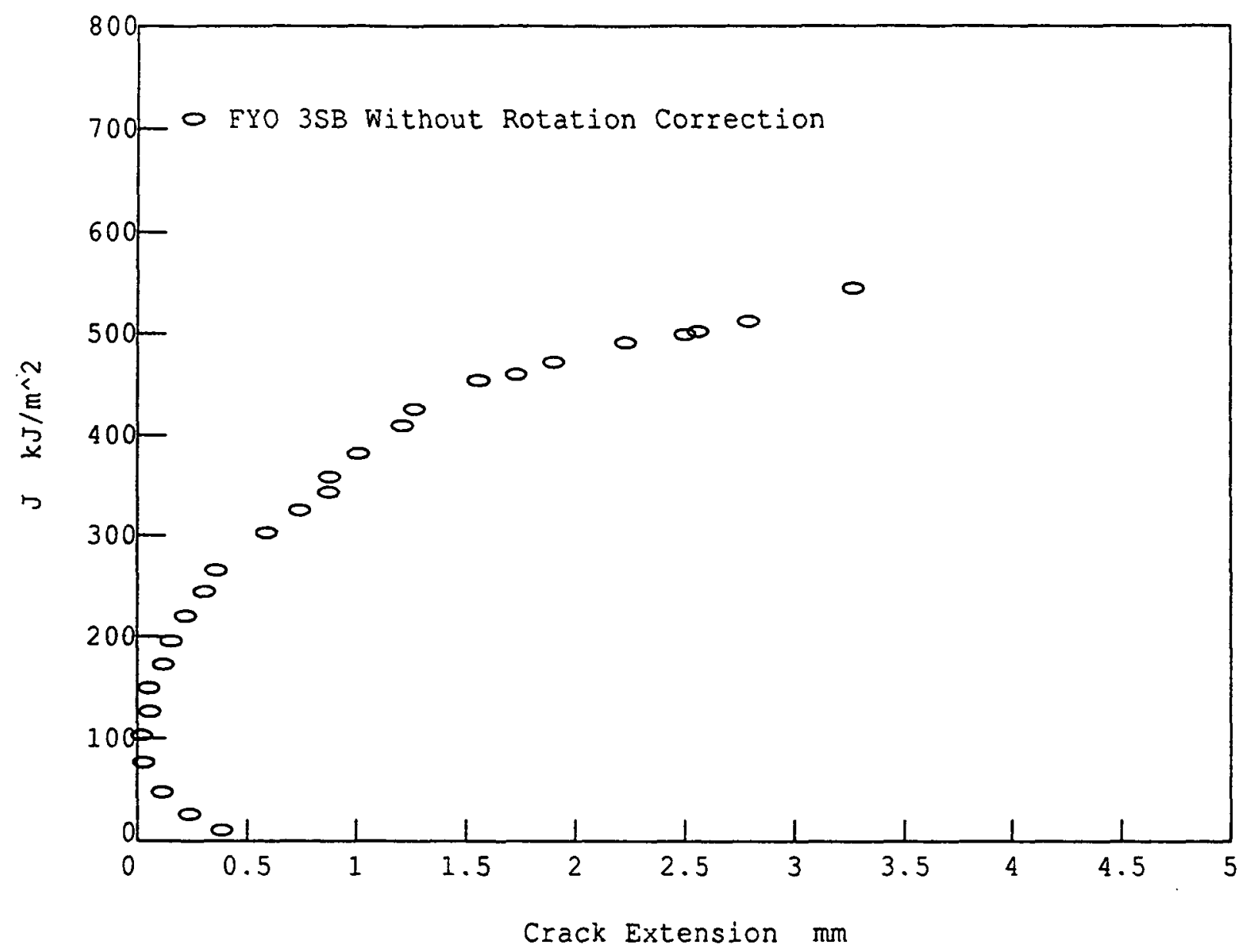

Figure 13 J-Resistance curve from an SE(T) specimen exhibiting "crack backup" in the early portion of the test. 


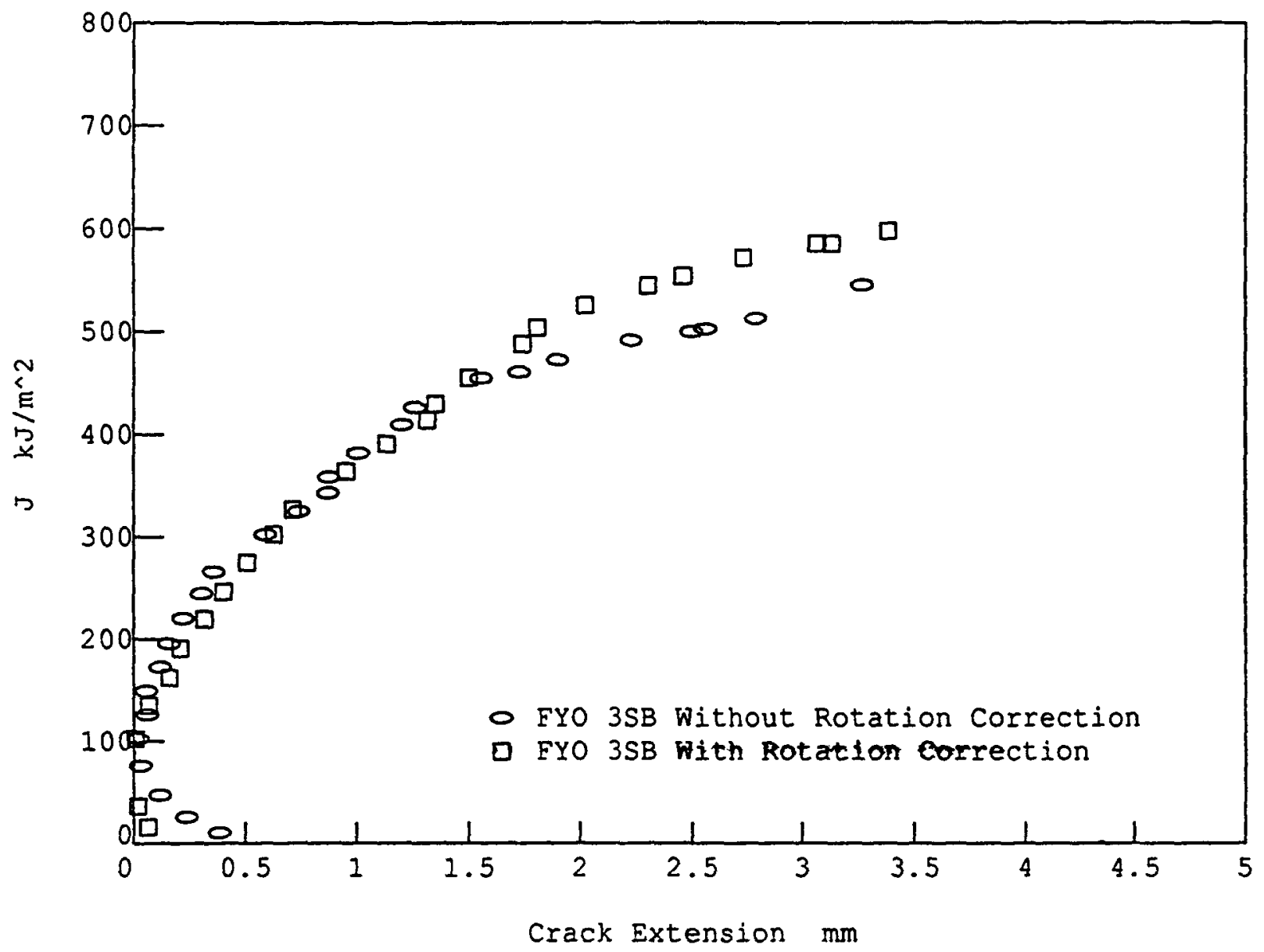

Figure 14 Comparison of J-R curves for an HY-100 SE(T) specimen with and without rotation correction. 


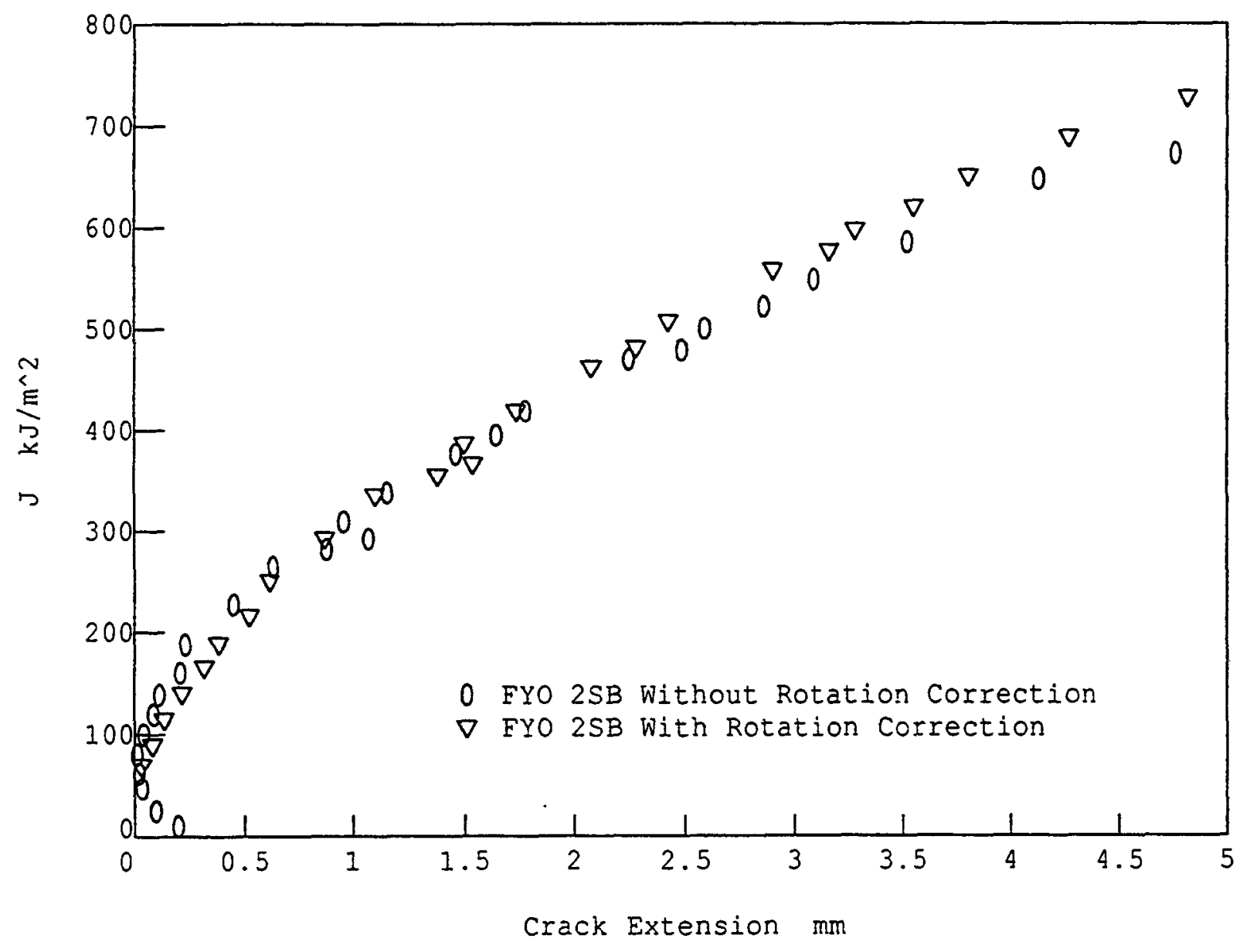

Figure 15 J-R curve for an HY-100 SE(T) specimen with and without rotation correction. 
Table 4 Fracture toughness and tearing modulus for HY-100 specimens.

\begin{tabular}{||c|c|c|c|c|c||}
\hline $\begin{array}{c}\text { Specimen } \\
\text { ID }\end{array}$ & Type & a/W & $\begin{array}{c}\text { B } \\
(\mathrm{mm})\end{array}$ & $\begin{array}{c}\mathrm{J}_{\text {Ic }} \\
\left(\mathrm{kJ} / \mathrm{mm}^{2}\right)\end{array}$ & $\begin{array}{c}\mathrm{T}_{\text {mat }} \\
(1 \mathrm{~mm})\end{array}$ \\
\hline \hline FYO 1 & SE(B) & 0.66 & 50. & 111.7 & 25.2 \\
\hline FYO 3 & SE(B) & 0.66 & 50. & 137.8 & 31.2 \\
\hline FYO 21 & SE(B) & 0.14 & 50. & 177.2 & 49.9 \\
\hline FYO 26 & SE(B) & 0.13 & 25. & 163.7 & 35.6 \\
\hline FYO 27 & SE(B) & 0.14 & 25. & 173.7 & 48.0 \\
\hline FYO 150 & SE(B) & 0.61 & 25. & 145.1 & 21.3 \\
\hline FYO 151 & SE(B) & 0.61 & 25. & 129.7 & 26.6 \\
\hline \hline FYO 158 & SE(B) & 0.60 & 12.5 & 140.5 & 23.8 \\
\hline FYO 159 & SE(B) & 0.62 & 12.5 & 179.9 & 24.2 \\
\hline FYO 160 & SE(B) & 0.11 & 12.5 & 120.1 & 38.2 \\
\hline FYO 161 & SE(B) & 0.11 & 12.5 & 113.9 & 40.9 \\
\hline \hline FYO 2SB & SE(T) & 0.40 & 25. & 166.7 & 47.9 \\
\hline FYO 3SB & SE(T) & 0.47 & 25. & 245.0 & 50.1 \\
\hline FYO 4SA & $\mathrm{SE}(\mathrm{T})$ & 0.65 & 25. & 254.1 & 31.5 \\
\hline FYO 10SA & $\mathrm{SE}(\mathrm{T})$ & 0.35 & 25. & 201.8 & 57.6 \\
\hline \hline FYO 11SB & $\mathrm{DE}(\mathrm{T})$ & 0.68 & 25. & 88.4 & 31.0 \\
\hline FYO 12SA & $\mathrm{DE}(\mathrm{T})$ & 0.61 & 25. & 107.1 & 39.2 \\
\hline \hline
\end{tabular}


Table 5 Fracture toughness and tearing modulus for A533B specimens.

\begin{tabular}{|c|c|c|c|c|}
\hline Specimen ID & Type & a/W & $\begin{array}{c}\mathrm{J}_{\mathrm{Ic}} \\
\mathrm{kJ} / \mathrm{m}^{2}\end{array}$ & $\begin{array}{c}\mathrm{T}_{\mathrm{mal}} \\
\mathrm{mm})\end{array}$ \\
\hline \hline CT3 & $\mathrm{C}(\mathrm{T})$ & 0.6 & 244.4 & 122.4 \\
\hline CT9 & $\mathrm{C}(\mathrm{T})$ & 0.6 & 265.0 & 125.3 \\
\hline CT10 & $\mathrm{C}(\mathrm{T})$ & 0.6 & 239.2 & 112.1. \\
\hline \hline DB1 & SE(B) & 0.62 & 240.3 & 149.9 \\
\hline DB2 & $\mathrm{SE}(\mathrm{B})$ & 0.62 & 308.5 & 142.9 \\
\hline DB3 & $\mathrm{SE}(\mathrm{B})$ & 0.62 & 323.8 & 160.5 \\
\hline \hline SB1 & $\mathrm{SE}(\mathrm{B})$ & 0.15 & 306.3 & 238.2 \\
\hline SB2 & $\mathrm{SE}(\mathrm{B})$ & 0.15 & 228.7 & 260.8 \\
\hline SB3 & $\mathrm{SE}(\mathrm{B})$ & 0.15 & 333.0 & 239.2 \\
\hline \hline SEN1 & $\mathrm{SE}(\mathrm{T})$ & 0.40 & 145.5 & 228.7 \\
\hline SEN2 & $\mathrm{SE}(\mathrm{T})$ & 0.36 & 159.5 & 289.8 \\
\hline SEN4 & $\mathrm{SE}(\mathrm{T})$ & 0.60 & 305.2 & 229.1 \\
\hline SEN9 & $\mathrm{SE}(\mathrm{T})$ & 0.40 & 598.6 & 288.4 \\
\hline SEN10 & $\mathrm{SE}(\mathrm{T})$ & 0.60 & 231.8 & 178.6 \\
\hline \hline SE5D & $\mathrm{DE}(\mathrm{T})$ & 0.7 & 164.6 & 301.1 \\
\hline SE6D & $\mathrm{DE}(\mathrm{T})$ & 0.7 & 182.1 & 257.3 \\
\hline SE7D & $\mathrm{DE}(\mathrm{T})$ & 0.68 & 189.8 & 253.3 \\
\hline SE8D & $\mathrm{DE}(\mathrm{T})$ & 0.71 & 226.6 & 255.0 \\
\hline
\end{tabular}




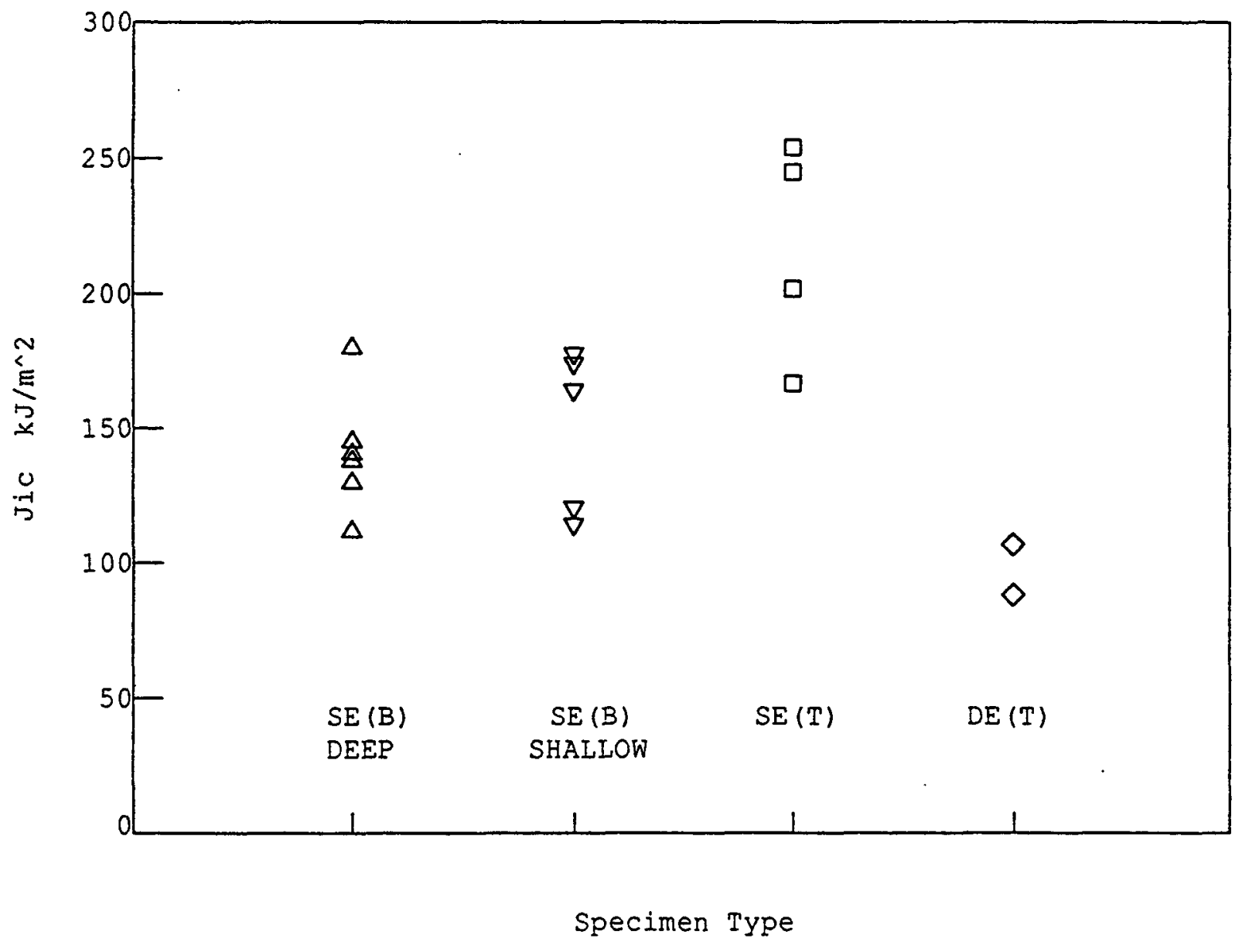

Figure 16 Fracture toughness of HY-100 as a function of specimen type. 


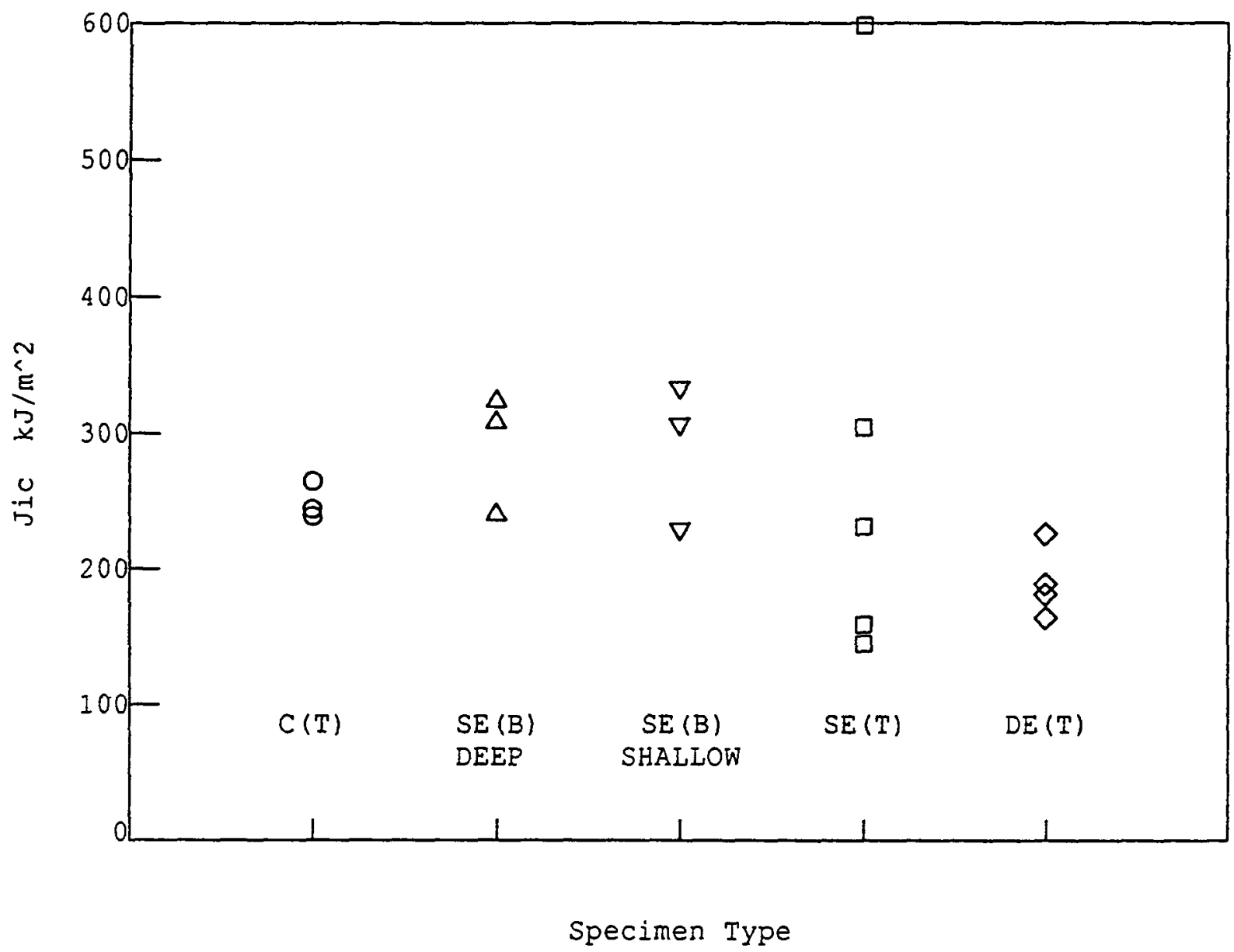

Figure 17 Fracture toughness of A533B as a function of specimen type. 
then evaluating $\mathrm{dJ} / \mathrm{da}$ at a crack extension of $1 \mathrm{~mm}(0.04 \mathrm{in})$. The measured $\mathrm{T}_{\mathrm{mat}}$ values obtained from this set of specimens are shown in Table 4 and Table 5 and plotted as a function of specimen type in Figure 18 and Figure 19. The tearing resistance varies for each material by a factor of about 2.5 and appears to be dependent on the specimen type.

In the following sections these results for $\mathrm{J}_{\mathrm{Ic}}$ and $\mathrm{T}_{\text {mat }}$ will be correlated with the $\mathrm{T}_{\sigma}$ and $Q$ constraint parameters introduced in Section 2.

\subsection{J-R Curves}

Figure 20 and Figure 21 show the measured J-R curves for the baseline, deep notched SE(B) and C(T) specimens of each material. The variability shown in these figures is assumed to be due to material variability, and is typical of what is usually found for structural steels. The dashed bounding lines shown in the figures will be used on later plots for comparison of the baseline results and results from the non-standard specimens. Comparisons of these baseline J-R curves with the J-R curves of the short cracked $S E(B), S E(T)$, and $D E(T)$ specimens for both materials are shown in Figures 22-27. The most immediate observation that can be made from these figures is that short cracks and tensile loading seem to have little effect on the $J_{1 c}$ value, but a measurable effect on the slope of the J-R curve, or $T_{\max }$ values, with higher slopes being found for all of the short crack and tensilely loaded specimens in comparison with the standard, deeply notched geometries.

The SE(T) specimen, SEN9, appears to be an outlier, with crack initiation being delayed for some unknown reason. This specimen has been explored extensively, but no reason has been found for its elevated toughness behavior. The pre-crack was straight, the initial and final crack lengths were estimated accurately by the compliance technique, and the load displacement curves seem correct in every respect. Figure 28 shows a plot of the load versus COD record for specimen SEN9 and also specimen SEN1, which had a nearly identical crack length. Specimen SEN9 is clearly much tougher, showing a continually rising load displacement record throughout the test, while specimen SEN1 rises to a maximum load and falls. The compliance method predicted crack initiation as shown on Figure 28, with the crack initiation of specimen SEN1 occurring at about the separation point of the two curves, while the crack initiation point for specimen SEN9 was much later. In both cases the extent of ductile crack growth agreed well with the post test optical measurement.

\section{$\underline{3.4 \text { Constraint Correlations }}$}

\subsection{1 $\mathrm{T}_{\alpha}$ Correlation}

The $T_{\sigma}$ quantity was calculated for each specimen from the applicable $K, a / W$, and $\beta$ at $\mathrm{J}_{\mathrm{Ic}}$ and is tabulated in Table 6 and Table 7. Figure 29 and Figure 30 show plots of $\mathrm{J}_{\mathrm{Ic}}$ versus $\mathrm{T}_{\sigma}$ for each material. The short and deep SE(B) specimens, and the C(T) specimens for the A533B alloy, appear to be insensitive to the applied $T_{\sigma}$ for both materials. The tensiley loaded SE(T) and $\mathrm{DE}(\mathrm{T})$ specimens are in general agreement, with the exception of specimen SEN9 for the A533B material, which was discussed previously as an apparent outlier. The HY100 tensilely 


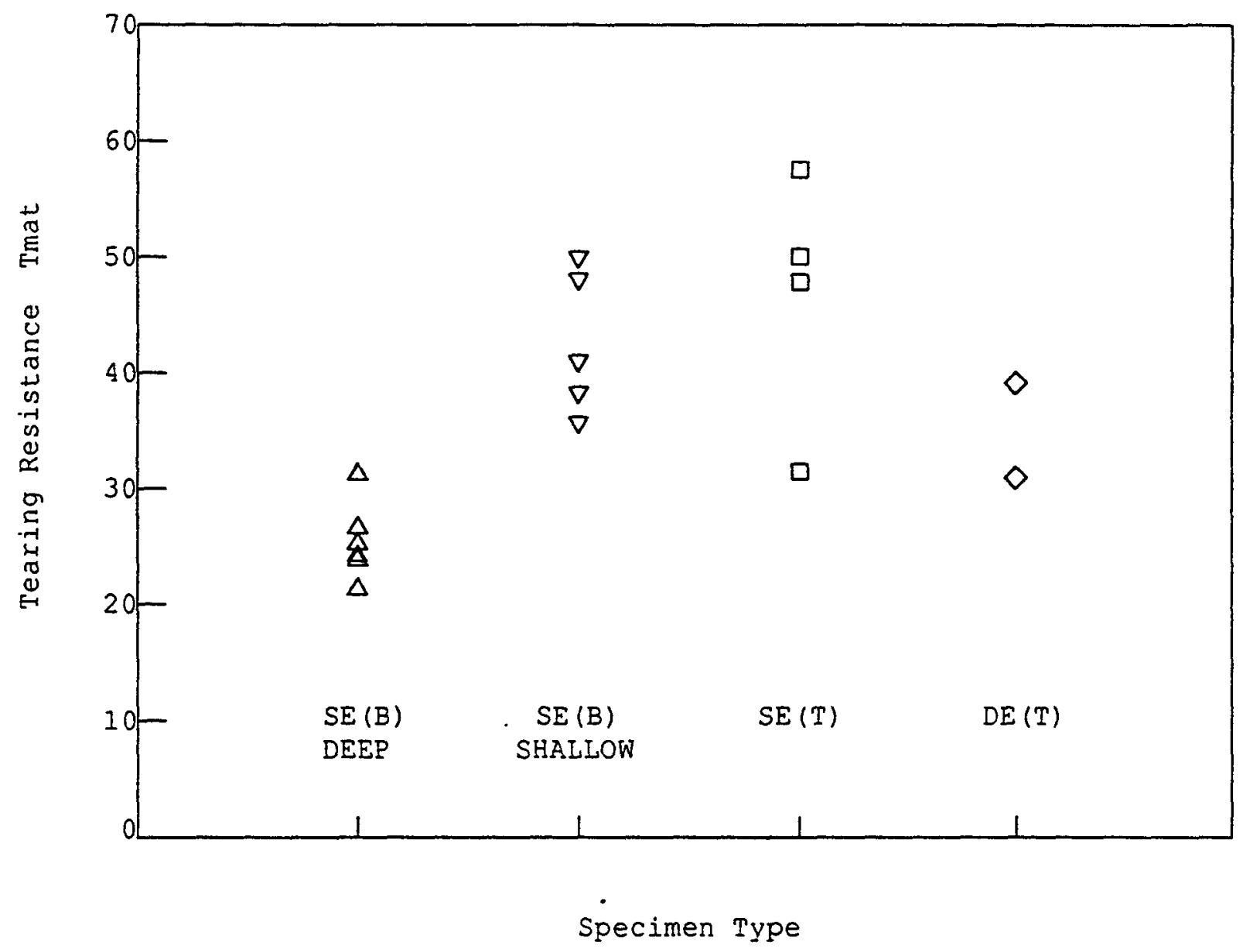

Figure 18 Tearing modulus of HY-100 as a function of specimen type. 


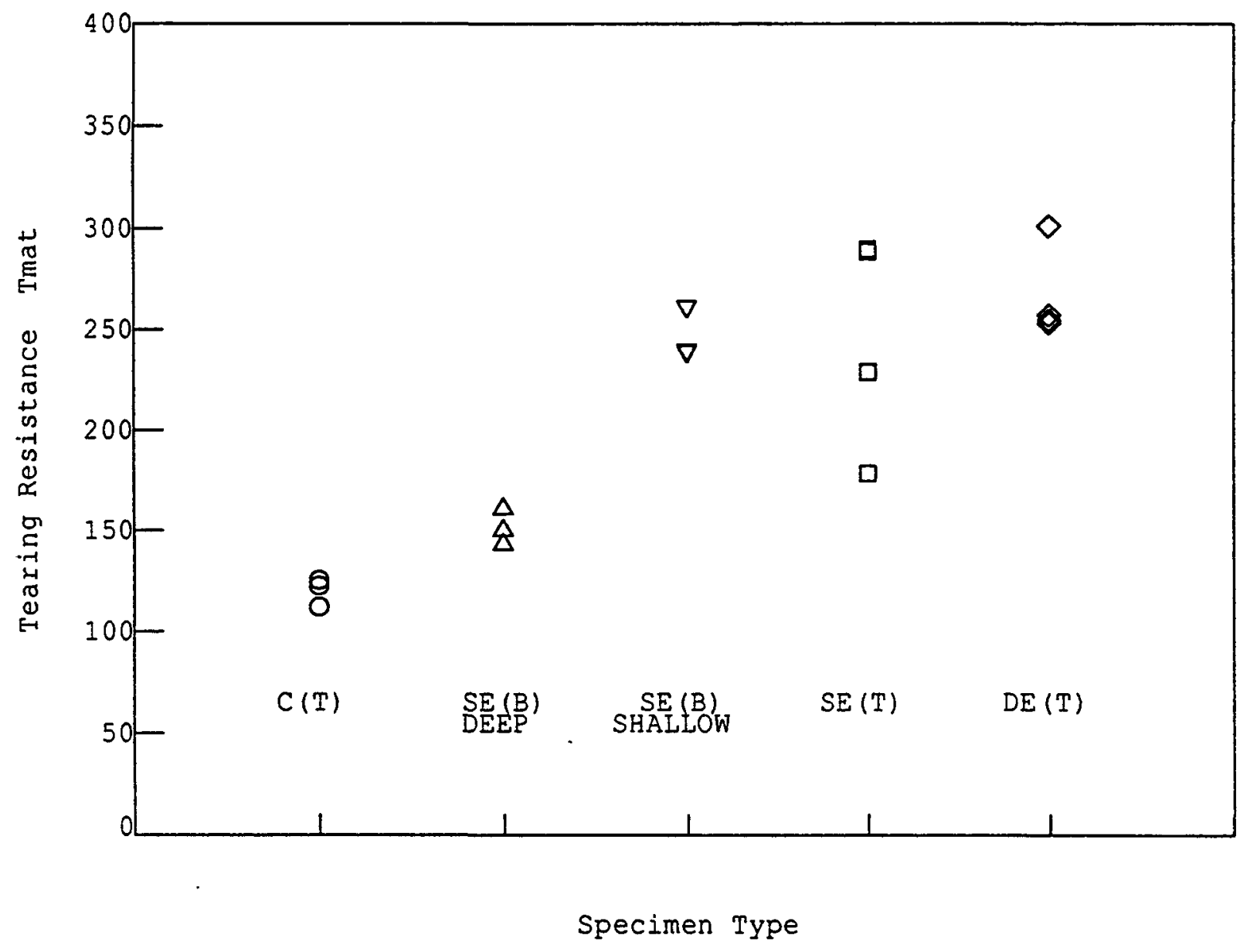

Figure 19 Tearing modulus of A533B as a function of specimen type. 


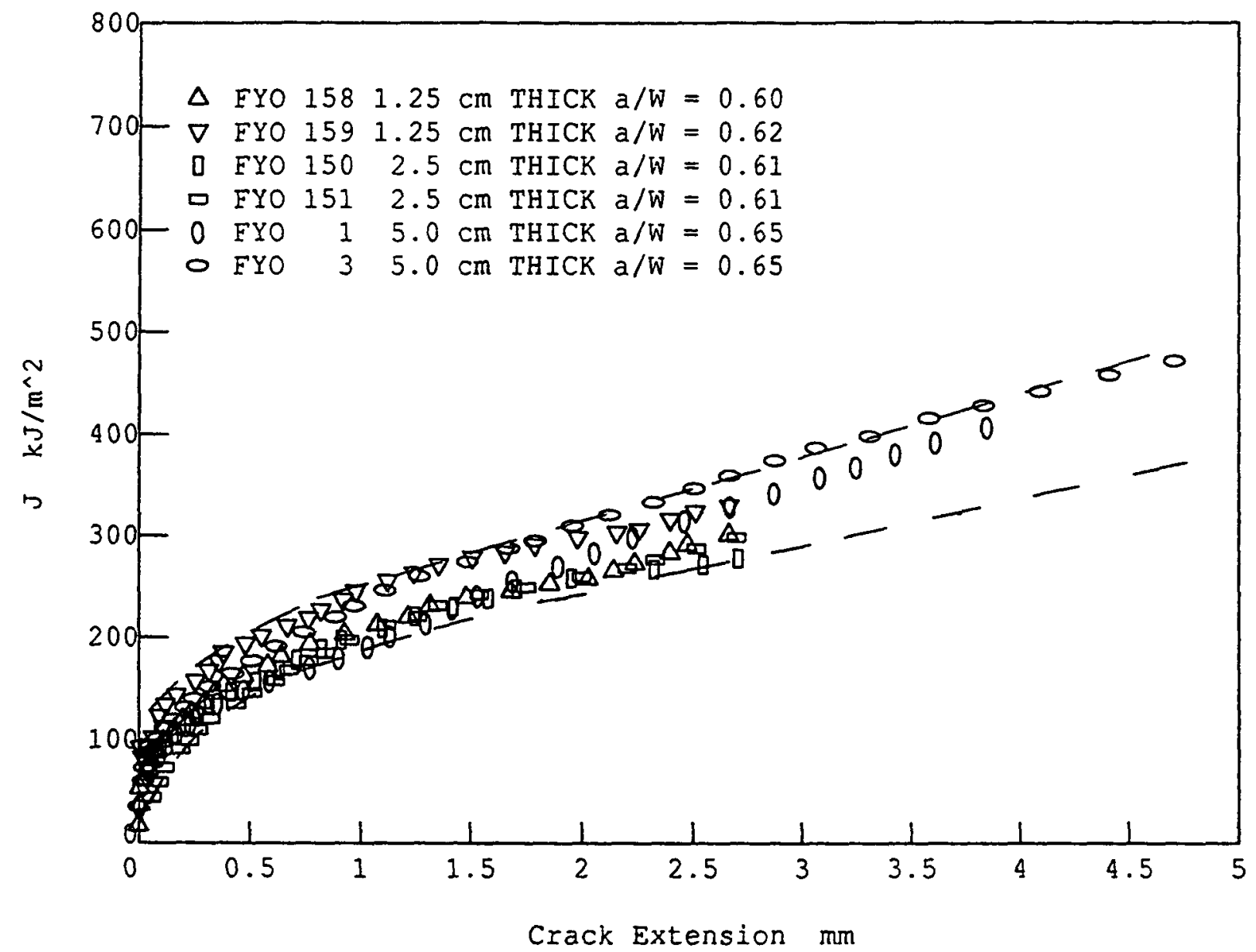

Figure 20 Baseline J-R curves for HY-100 from deep-cracked SE(B) specimens. 


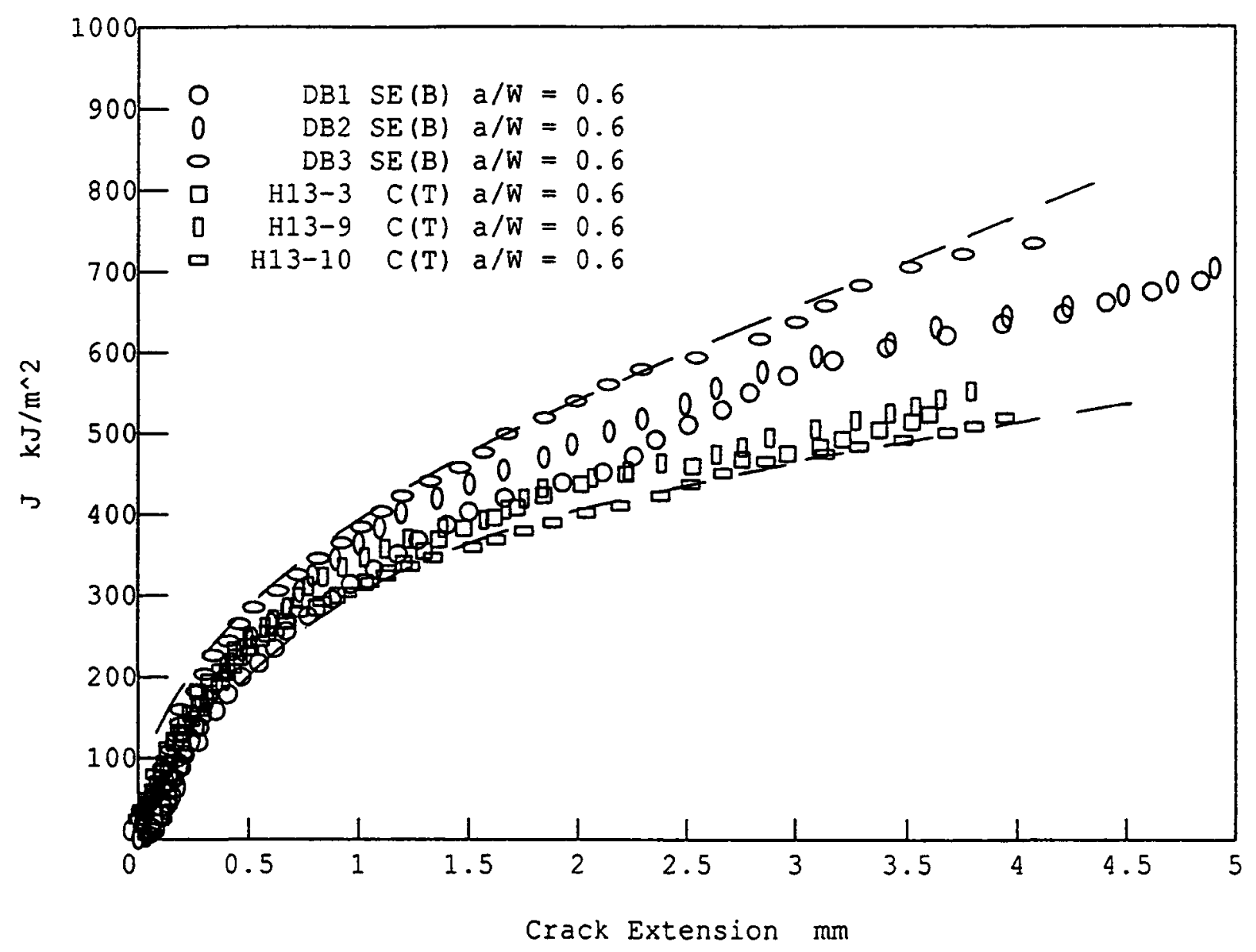

Figure 21 Baseline J-R curves for A533B from deep-cracked $S E(B)$ and $C(T)$ specimens. 


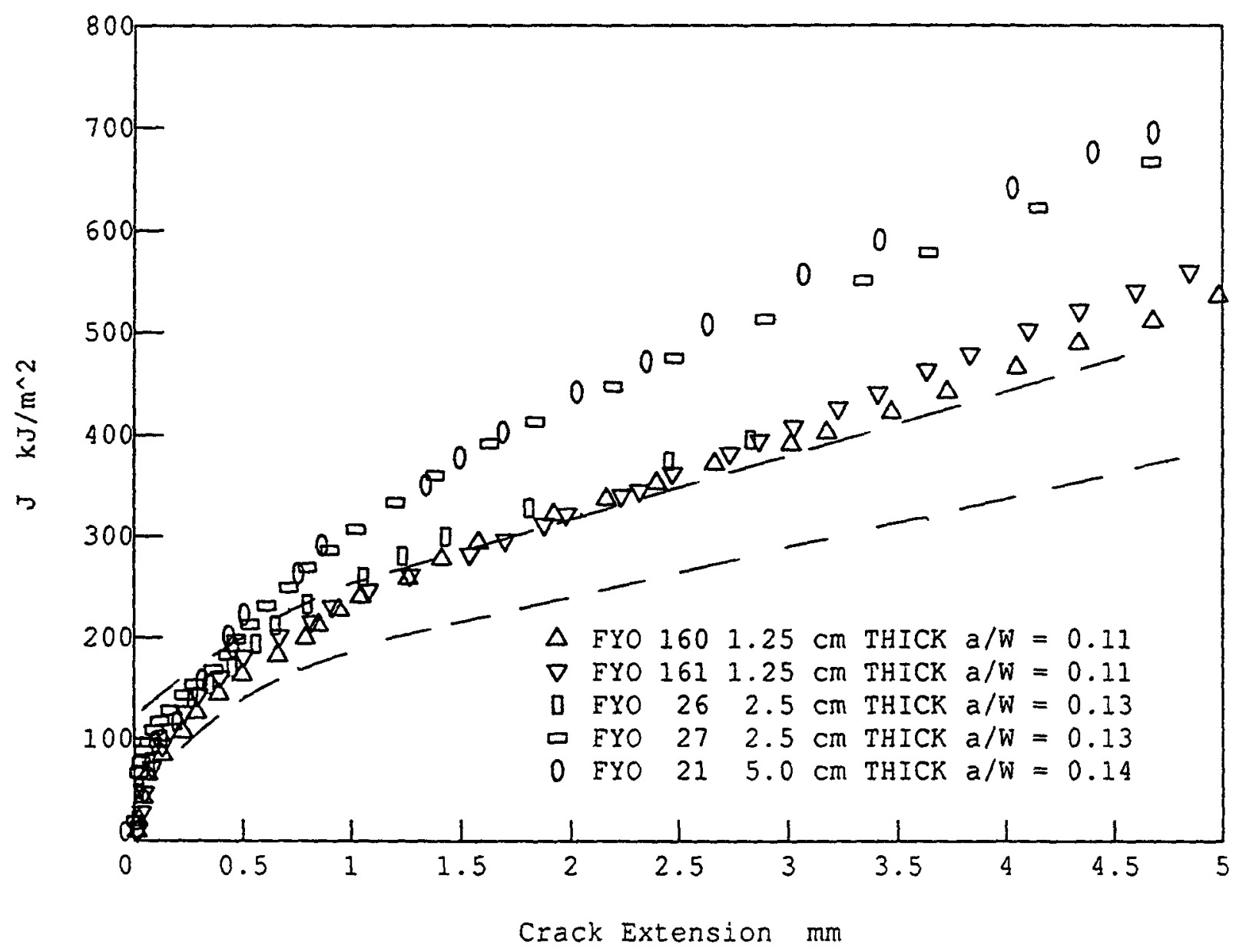

Figure 22 J-R curves for HY-100 from short-cracked $S E(B)$ specimens. 


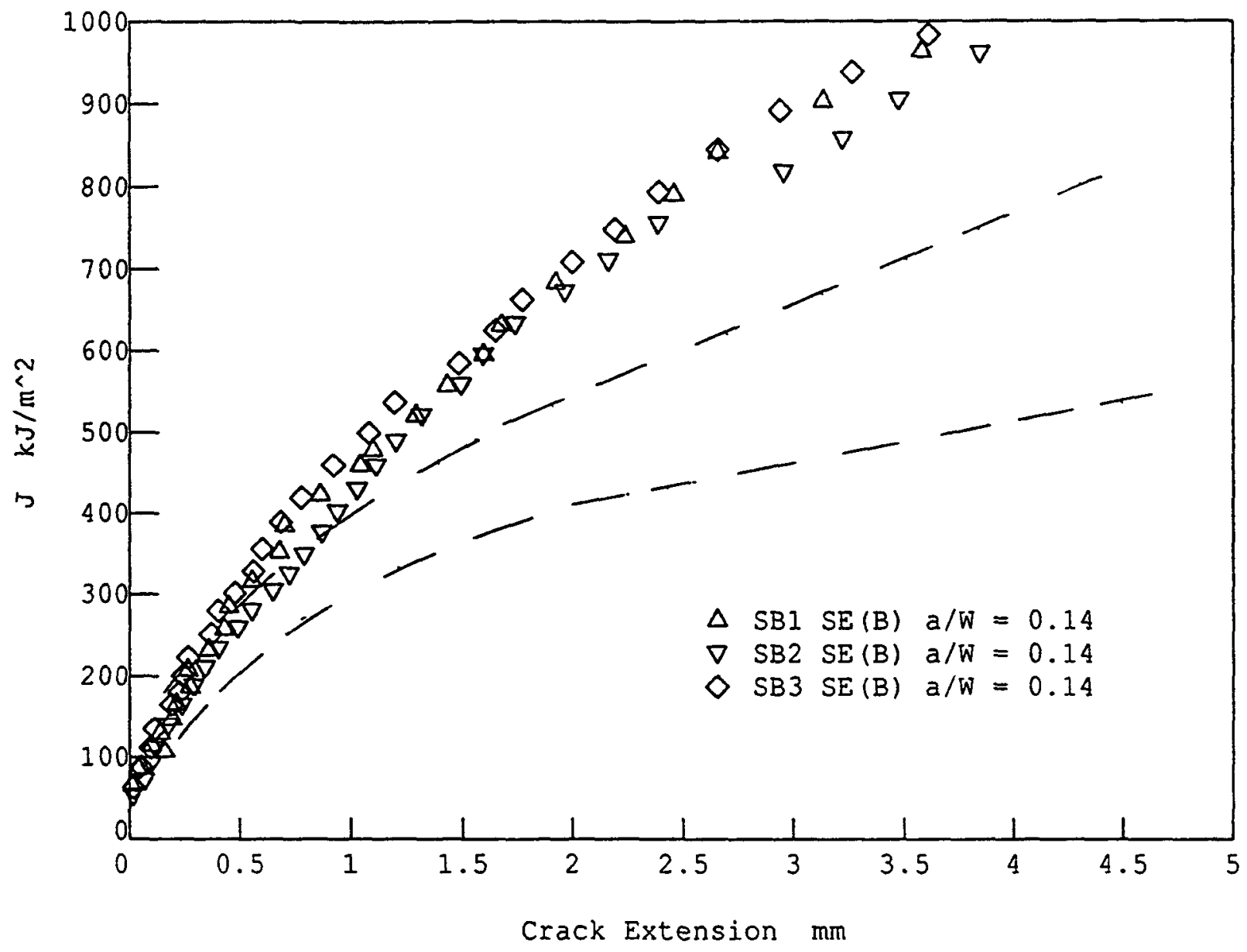

Figure 23 J-R curves for A533B from short-cracked SE(B) specimens. 


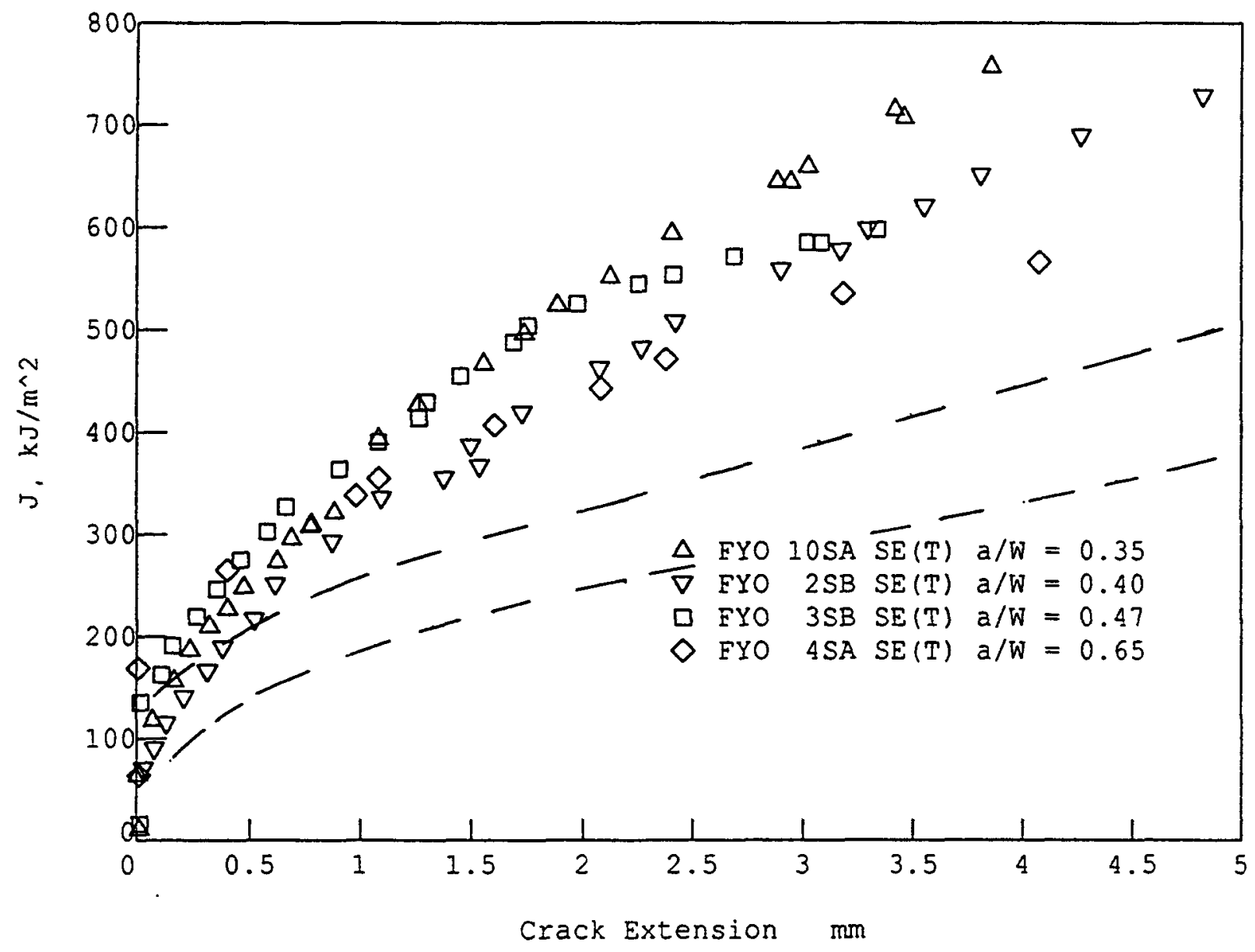

Figure 24 J-R curves for HY-100 from SE(T) specimens (with rotation correction). 


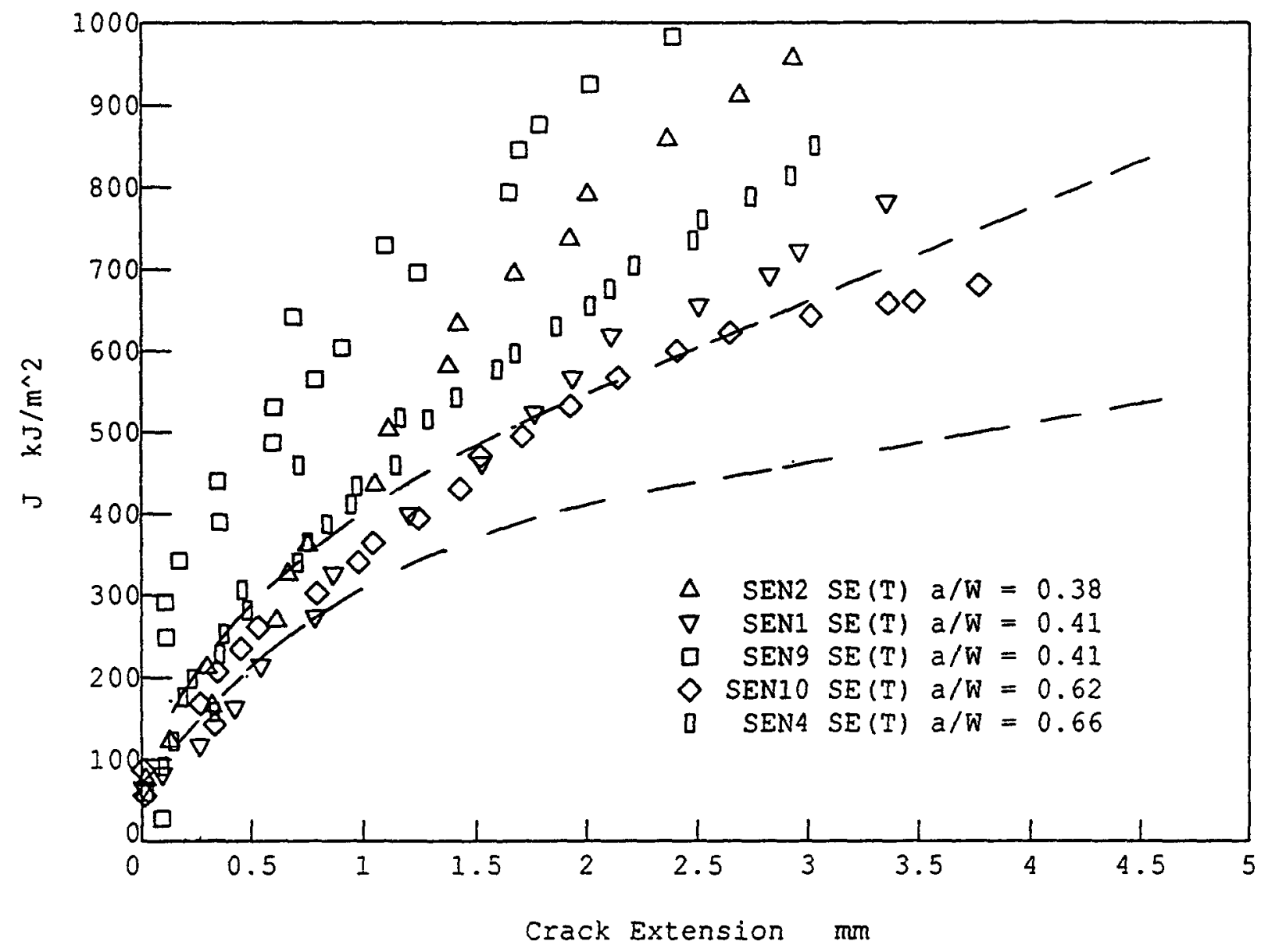

Figure $25 J-R$ curves for A533B from $S E(T)$ specimens (with rotation correction). 


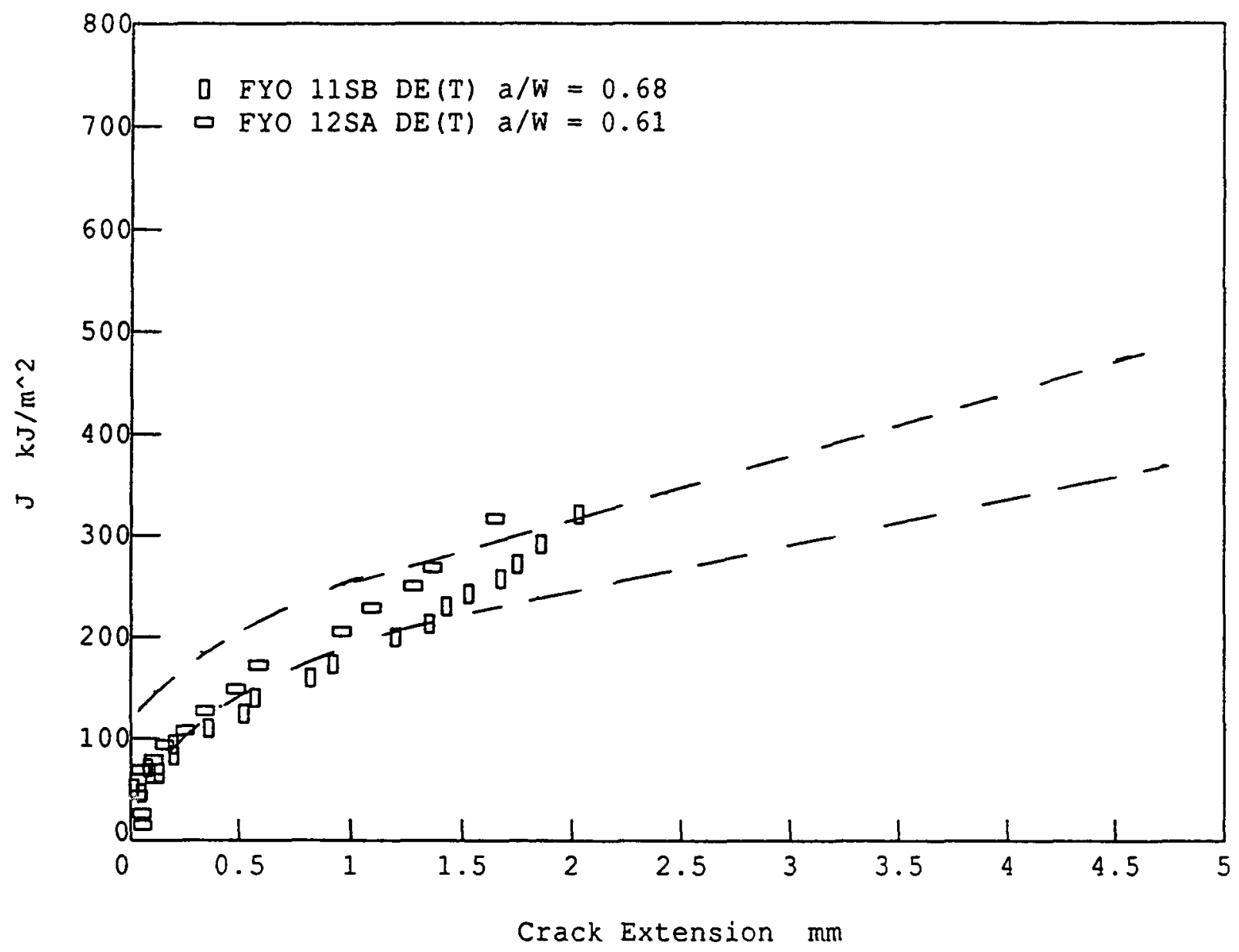

Figure 26 J-R curves for HY-100 from DE(T) specimens. 


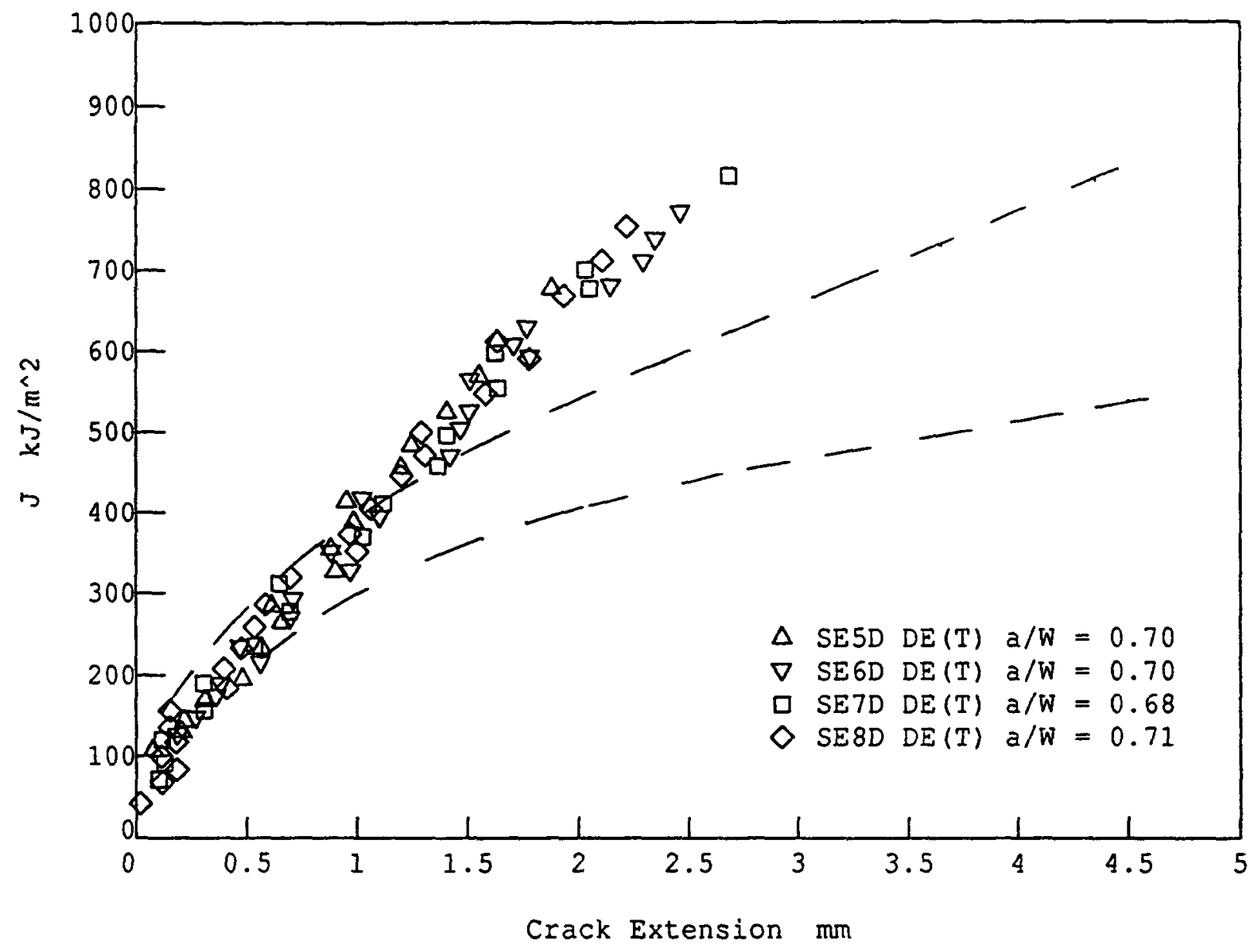

Figure $27 \quad J-R$ curves for A533B from $D E(T)$ specimens. 


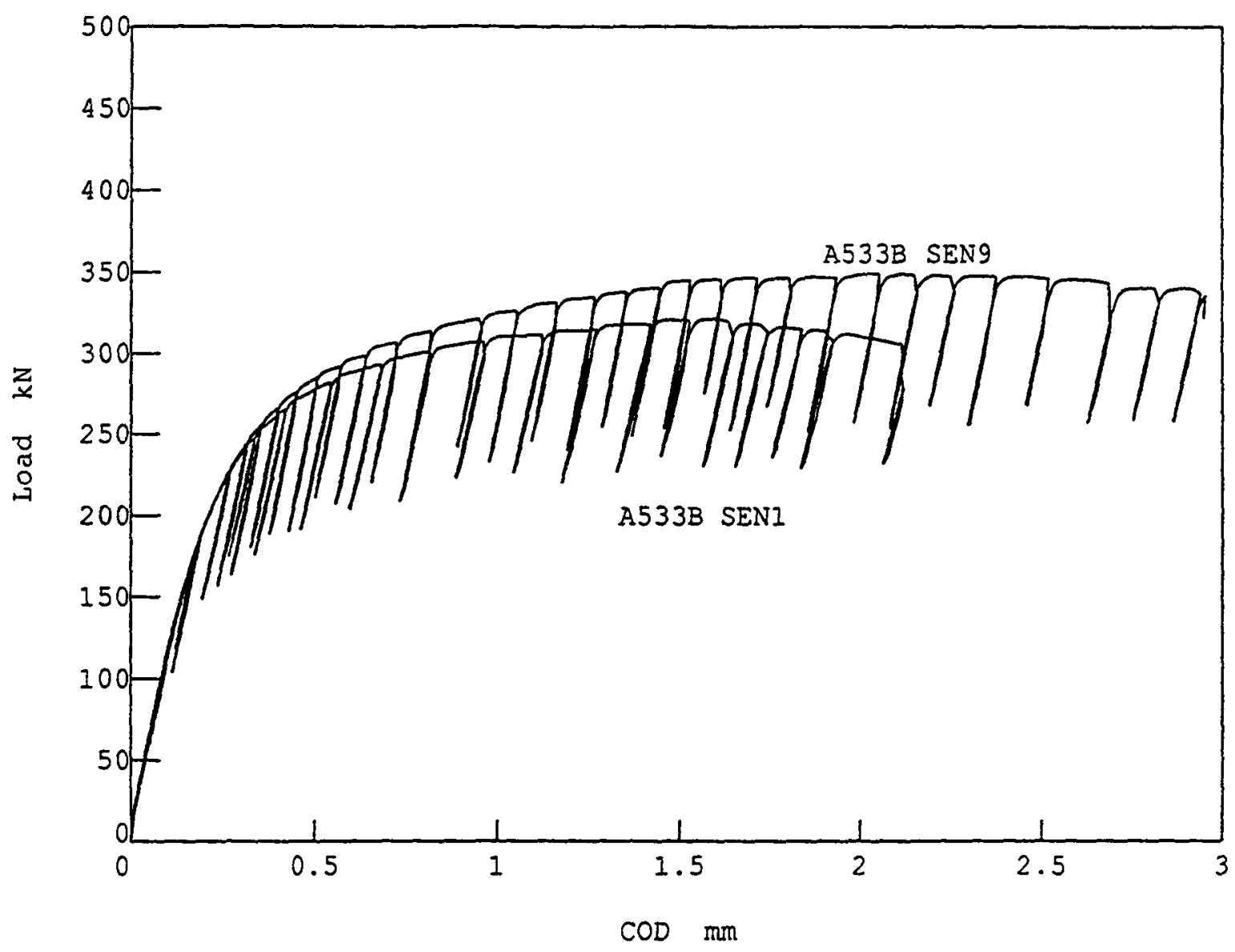

Figure 28 Load versus COD curves for specimens SEN9 and SEN1 of A533B. 
Table 6 Constraint parameters $\beta, T_{\sigma}$, and $Q$ at crack initiation in the HY-100 specimens.

\begin{tabular}{||c|c|c|c|c|c|c||}
\hline $\begin{array}{c}\text { Specimen } \\
\text { ID }\end{array}$ & Type & a/W & $\begin{array}{c}\text { B } \\
\mathrm{mm}\end{array}$ & $\beta$ & $\begin{array}{c}\mathrm{T}_{\sigma} @ \mathrm{~J}_{\mathrm{Ic}} \\
\mathrm{MPa}\end{array}$ & $\mathrm{Q} @ \mathrm{~J}_{\mathrm{Ic}}$ \\
\hline FYO 1 & SE(B) & 0.66 & 50. & 0.476 & 229. & -0.1 \\
\hline FYO 3 & SE(B) & 0.66 & 50. & 0.476 & 255. & -0.1 \\
\hline FYO 21 & SE(B) & 0.14 & 50. & -0.311 & -410. & -0.8 \\
\hline \hline FYO 26 & SE(B) & 0.13 & 25. & -0.322 & -425. & -0.8 \\
\hline FYO 27 & SE(B) & 0.14 & 25. & -0.311 & -406. & -0.8 \\
\hline FYO 150 & SE(B) & 0.61 & 25. & 0.395 & 226. & -0.1 \\
\hline FYO 151 & SE(B) & 0.61 & 25. & 0.395 & 213. & -0.1 \\
\hline \hline FYO 158 & SE(B) & 0.60 & 12.5 & 0.381 & 216. & -0.1 \\
\hline FYO 159 & SE(B) & 0.62 & 12.5 & 0.411 & 259. & -0.1 \\
\hline FYO 160 & SE(B) & 0.11 & 12.5 & -0.345 & -423. & -0.8 \\
\hline FYO 161 & SE(B) & 0.11 & 12.5 & -0.345 & -412. & -0.8 \\
\hline \hline FYO 2SB & SE(T) & 0.40 & 25. & -0.270 & -182. & -0.25 \\
\hline FYO 3SB & SE(T) & 0.47 & 25. & -0.183 & -138 & -0.30 \\
\hline FYO 4SA & SE(T) & 0.65 & 25. & -0.101 & -65.9 & -0.11 \\
\hline FYO 10SA & SE(T) & 0.35 & 25. & -0.325 & -259. & -0.31 \\
\hline \hline FYO 11SB & DE(T) & 0.68 & 25. & -0.407 & -217. & -0.43 \\
\hline FYO 12SA & DE(T) & 0.61 & 25. & -0.433 & -268. & -0.40 \\
\hline \hline
\end{tabular}


Table 7 Constraint parameters $\beta, T_{\sigma}$, and $Q$ at crack initiation for the A533B specimens.

\begin{tabular}{|c|c|c|c|c|c||}
\hline Specimen ID & Type & a/W & $\beta$ & $\begin{array}{c}\mathrm{T}_{\sigma} @ \mathrm{~J}_{\mathrm{Ic}} \\
\mathrm{MPa}\end{array}$ & $\mathrm{Q} @ \mathrm{~J}_{\mathrm{Ic}}$ \\
\hline \hline CT3 & $\mathrm{C}(\mathrm{T})$ & 0.6 & 0.573 & 428. & -0.1 \\
\hline CT9 & $\mathrm{C}(\mathrm{T})$ & 0.6 & 0.573 & 446. & -0.1 \\
\hline CT10 & $\mathrm{C}(\mathrm{T})$ & 0.6 & 0.573 & 423. & -0.1 \\
\hline DB1 & SE(B) & 0.62 & 0.411 & 300. & -0.1 \\
\hline DB2 & SE(B) & 0.62 & 0.411 & 339. & -0.1 \\
\hline DB3 & SE(B) & 0.62 & 0.411 & 348. & -0.1 \\
\hline \hline SB1 & SE(B) & 0.15 & -0.299 & -498. & -0.8 \\
\hline SB2 & SE(B) & 0.15 & -0.299 & -431. & -0.8 \\
\hline SB3 & SE(B) & 0.15 & -0.299 & -520. & -0.8 \\
\hline \hline SEN1 & SE(T) & 0.40 & -0.271 & -172. & -0.30 \\
\hline SEN2 & SE(T) & 0.36 & -0.315 & -220. & -0.30 \\
\hline SEN4 & SE(T) & 0.60 & 0.009 & 6.7 & -0.22 \\
\hline SEN9 & SE(T) & 0.40 & -0.271 & -348. & -0.60 \\
\hline SEN10 & SE(T) & 0.60 & 0.009 & 5.8 & -0.20 \\
\hline \hline SE5D & DE(T) & 0.7 & -.0397 & -285. & -0.70 \\
\hline SE6D & DE(T) & 0.7 & -0.397 & -300. & -0.71 \\
\hline SE7D & DE(T) & 0.68 & -0.407 & -311. & -0.72 \\
\hline SE8D & DE(T) & 0.71 & -0.392 & -335. & -0.76 \\
\hline
\end{tabular}




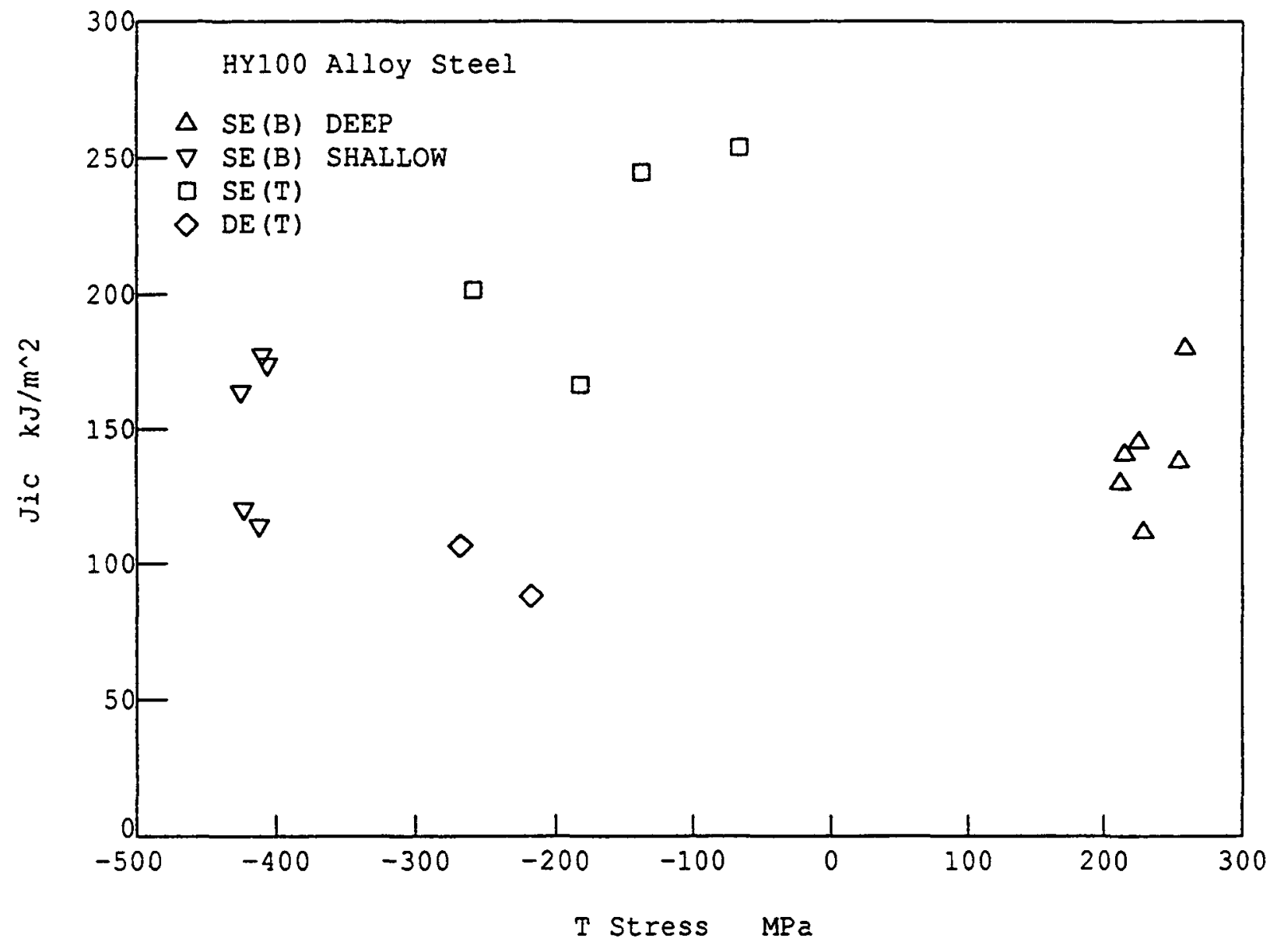

Figure 29 Fracture toughness, $\mathrm{J}_{\mathrm{lc}}$, as a function of $\mathrm{T}_{\sigma}$ for the HY-100 specimens. 


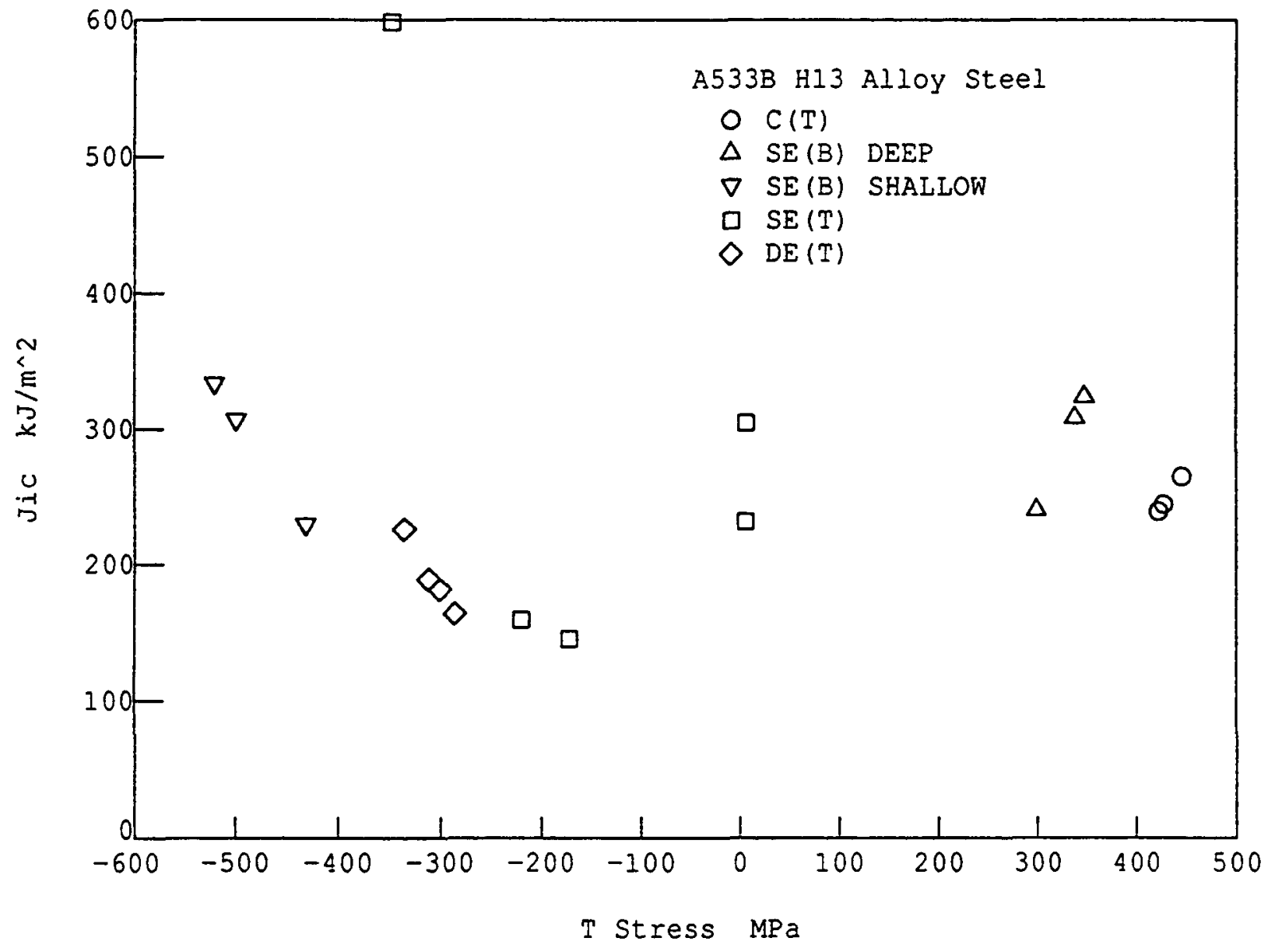

Figure 30 The fracture toughness, $J_{I E}$, as a function of $T_{\sigma}$ for the A533B specimens. 
loaded specimens show considerable scatter, with the $\mathrm{SE}(\mathrm{T})$ specimens being high relative to the $S E(B)$ results and the $D E(T)$ specimens being low. It is quite possible that improvements in test technique that have been incorporated in the more recent A533B tests in part explain the reduction in scatter shown by the A533B tensile results, in comparison with the earlier HY100 results.

Figure 31 and Figure 32 show plots of $T_{\text {mat }}$ versus $T_{\sigma}$ for each material, and now a clear trend of material tearing resistance versus constraint is apparent in the data, with the tearing resistance being more than doubled when measured with the low constraint short crack SE(B) specimen, in comparison to the standard, high constraint, deeply notched bend or compact specimens. The HY100 again shows much more scatter in $\mathrm{T}_{\text {mat }}$ values than does the A533B material. This might be due, in part, to the much smaller $T_{\text {mat }}$ values obtained from the HY100 material, as well as from basic improvements in the $S E(T)$ and $D E(T)$ test methods between the HY100 tests and the A533B tests. The appearance of these results is improved by the lower scatter for each specimen type demonstrated by the $T_{\text {mat }}$ parameter, in comparison with the $J_{I c}$ parameter.

\subsubsection{Q Correlation}

The $\mathrm{Q}$ quantity was evaluated for each specimen from the applicable analysis using Figs. 8-10, and the $\mathrm{J}_{\mathrm{Ic}}$ and $\mathrm{a} / \mathrm{W}$ and is tabulated in Table 6 and Table 7 for each specimen tested. Figure 33 and Figure 34 show plots of $\mathrm{J}_{\mathrm{Ic}}$ versus $\mathrm{Q}$ at $\mathrm{J}_{\mathrm{Ic}}$ for all specimens of each material. As above, neither material shows dependence of $J_{I c}$ on $Q$, at least, any that can be separated from the material and test variability. The HY100 shows much more scatter than is shown by the A533B material. Overall it seems that $\mathrm{J}_{\mathrm{Ic}}$ is not strongly affected by constraint, as measured by $Q$, in these specimen geometries.

Figure 35 and Figure 36 show plots of $T_{\text {mat }}$ versus $Q$ (at $J_{\mathrm{Ic}}$ ) for each material. A clear trend is now shown, with higher constraint resulting in lower tearing resistance in these materials. For both materials there appears to be a rapid increase in $T_{m a t}$ with decreasing $Q$, then a leveling off at lower Q's. 


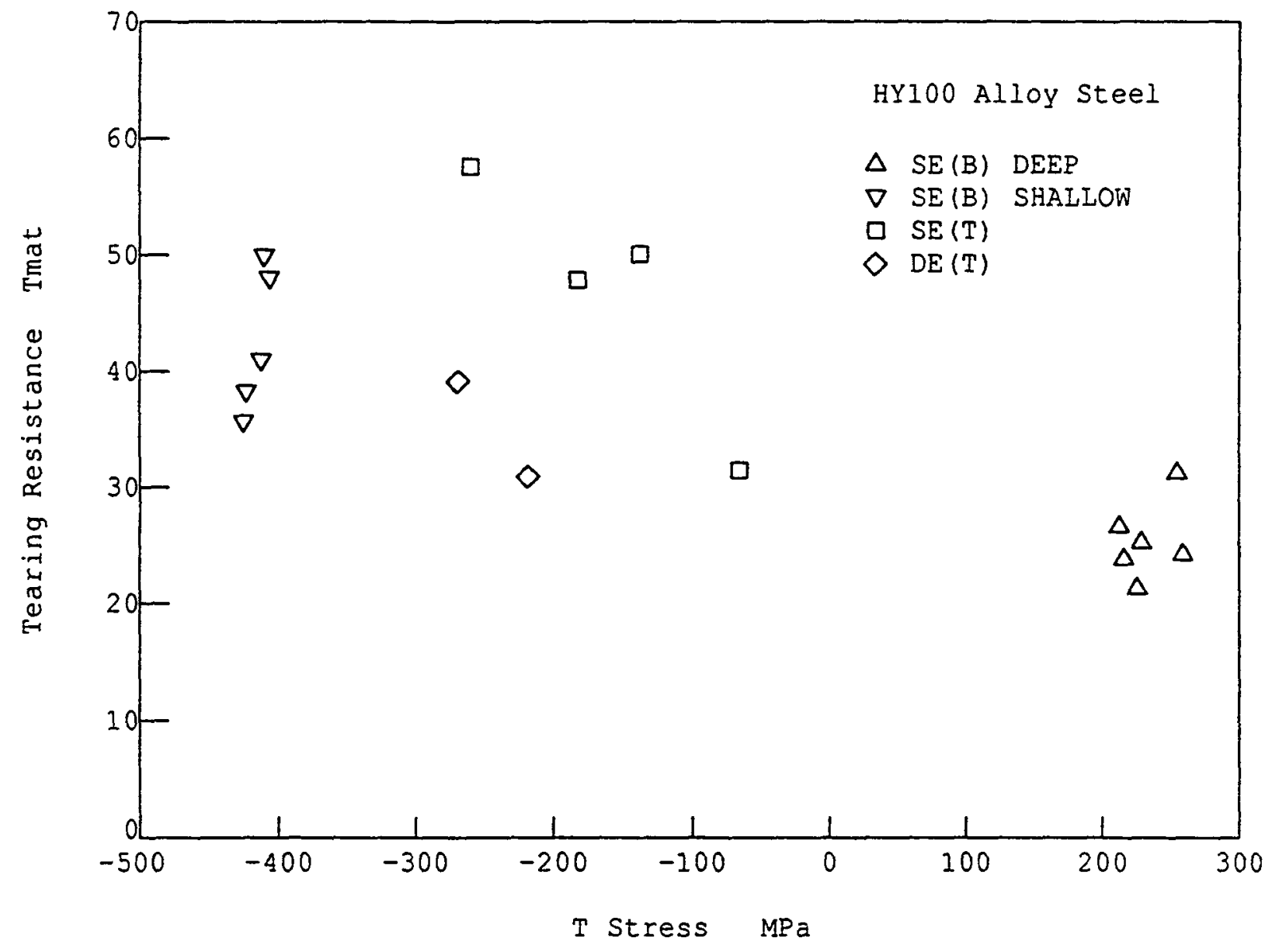

Figure 31 Tearing modulus, $T_{\operatorname{mas}}$, as a function of $T_{\sigma}$ for the HY-100 specimens. 


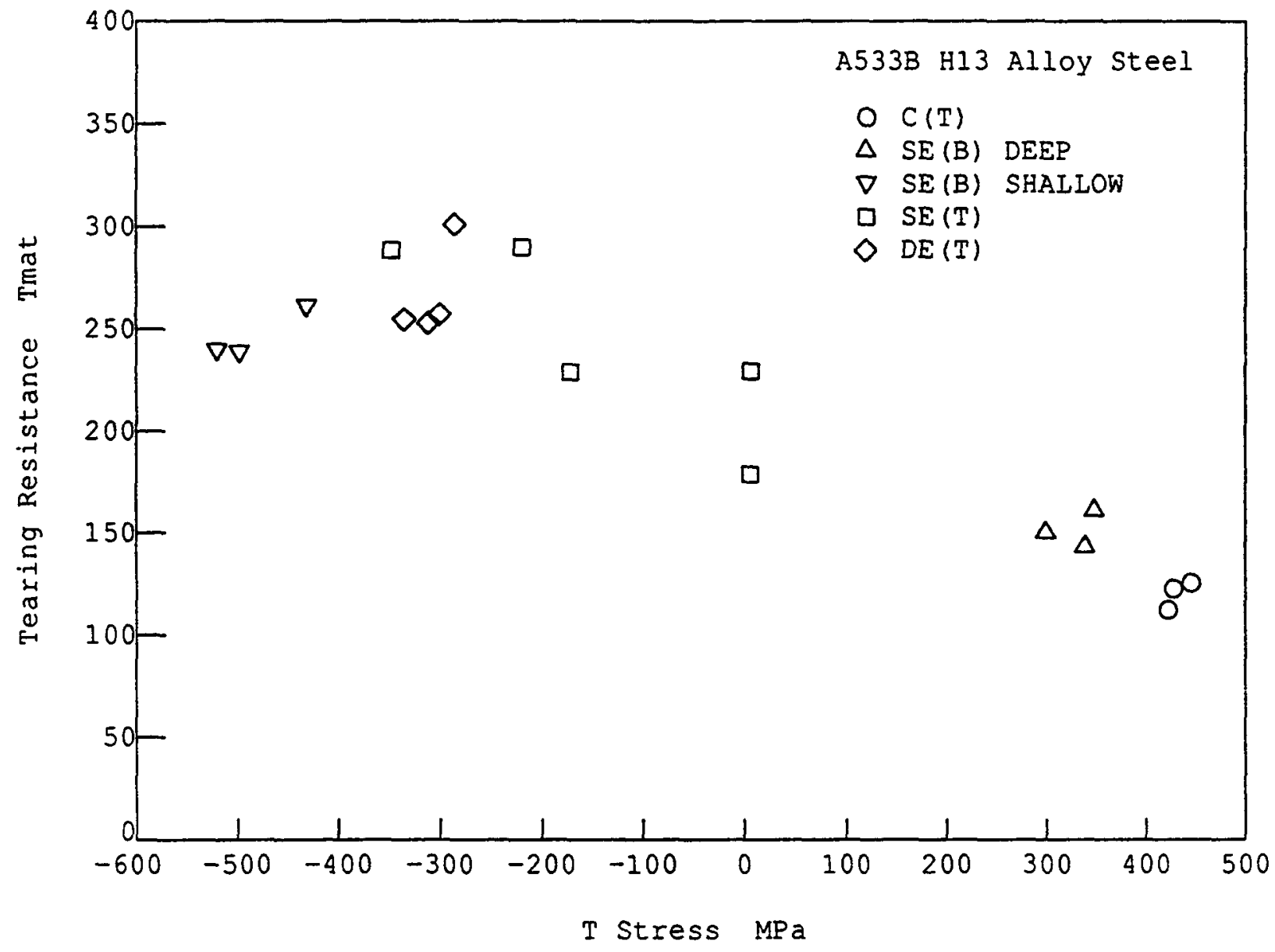

Figure 32 Tearing modulus, $T_{\text {mar }}$, as a function of $T_{\sigma}$ for the A533B specimens. 


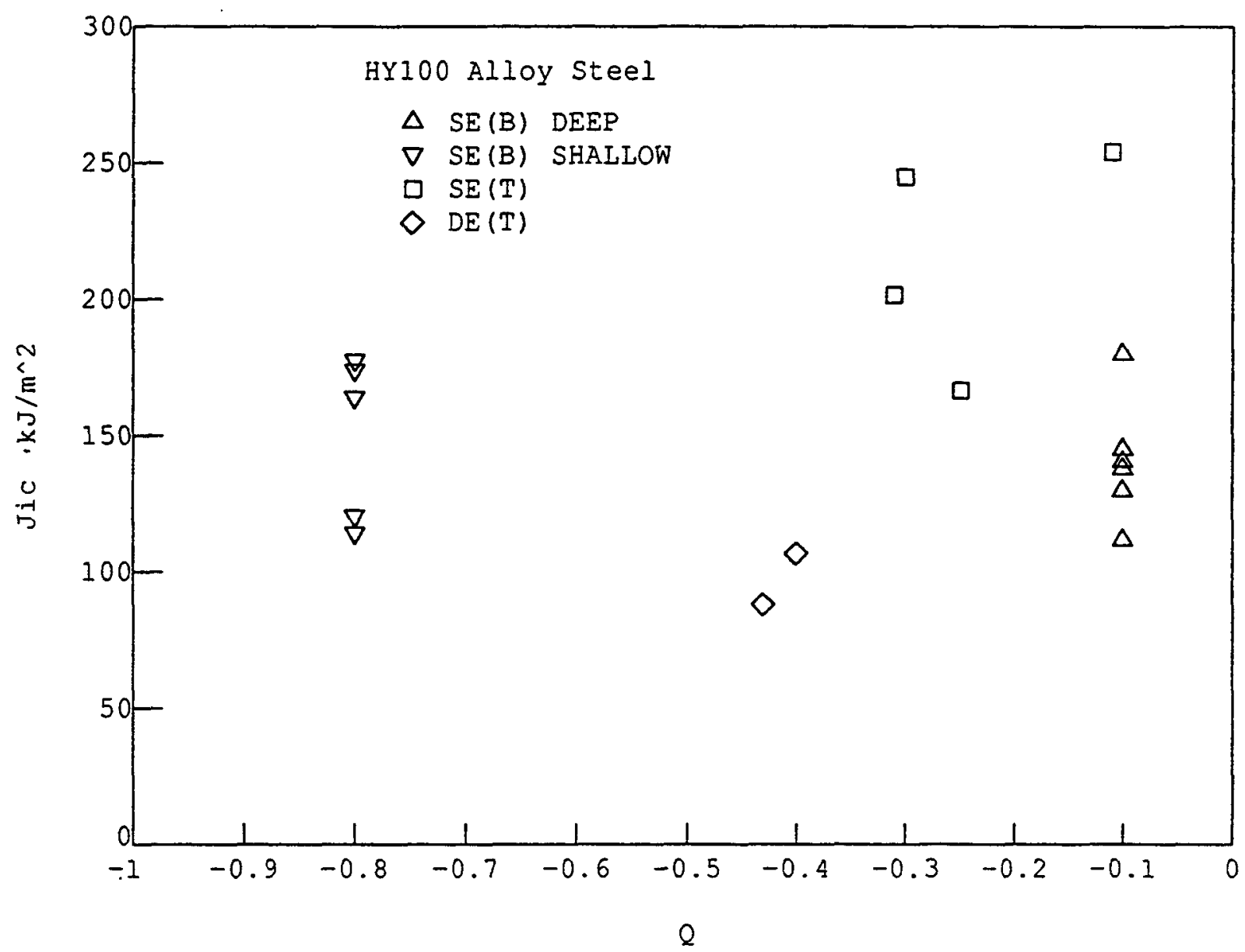

Figure 33 Fracture toughness, $\mathrm{J}_{\mathrm{Ic}}$, as a function of $\mathrm{Q}$ for the HY-100 specimens. 


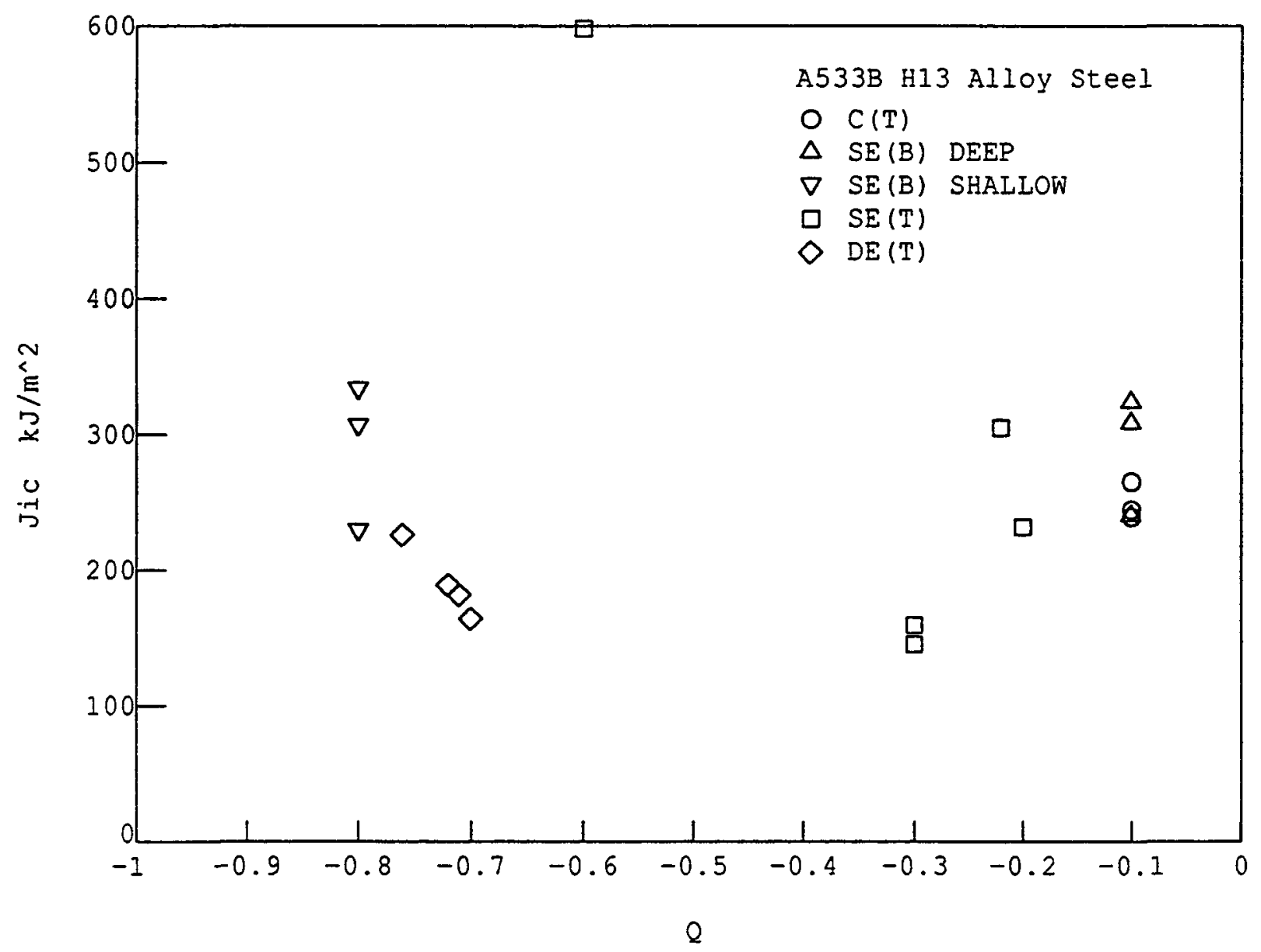

Figure 34 Fracture toughness, $\mathrm{J}_{\mathrm{lc}}$, as a function of $\mathrm{Q}$ for the A533B specimens. 


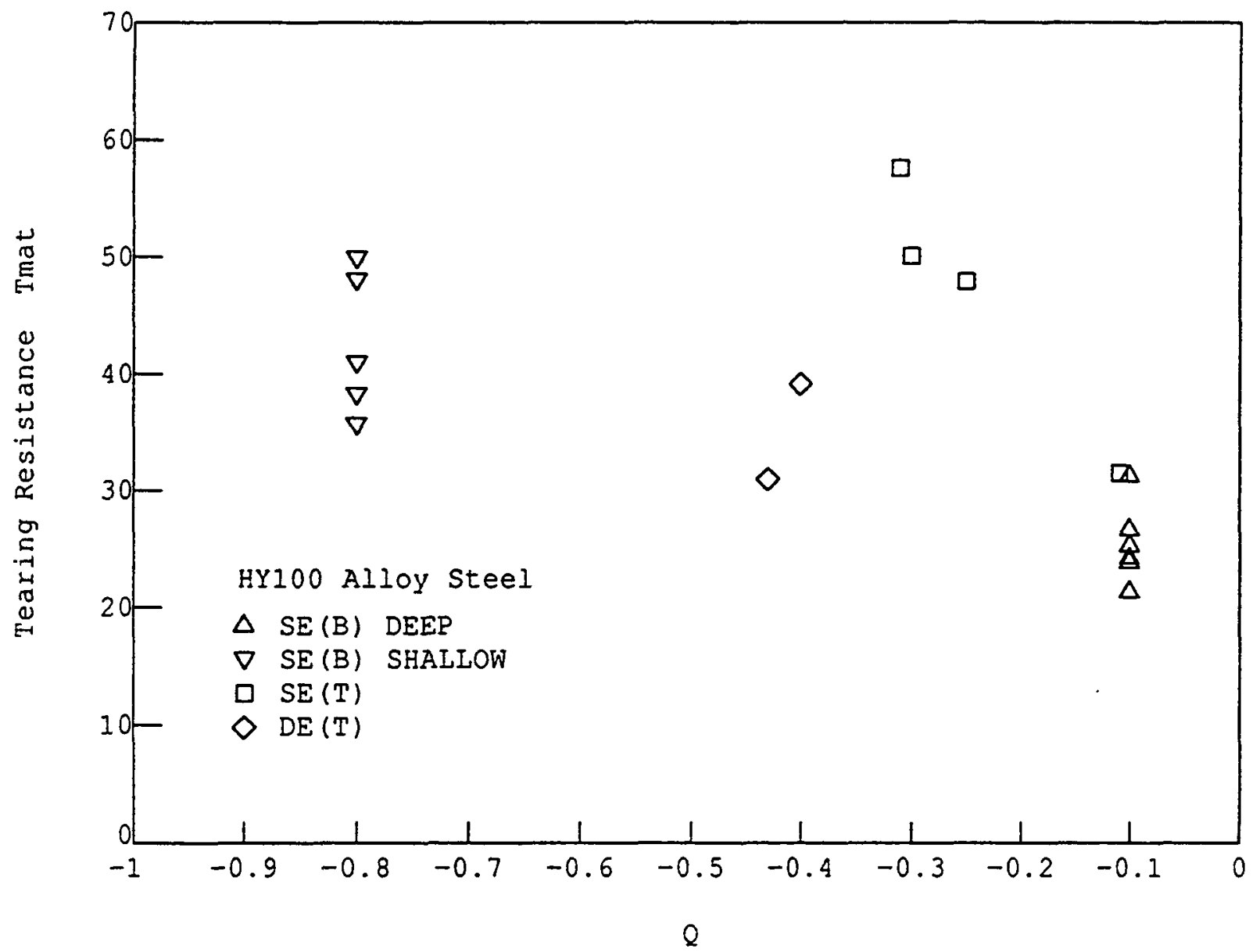

Figure 35 Tearing modulus, $T_{\text {mat }}$, as a function of $Q$ for the HY-100 specimens. 


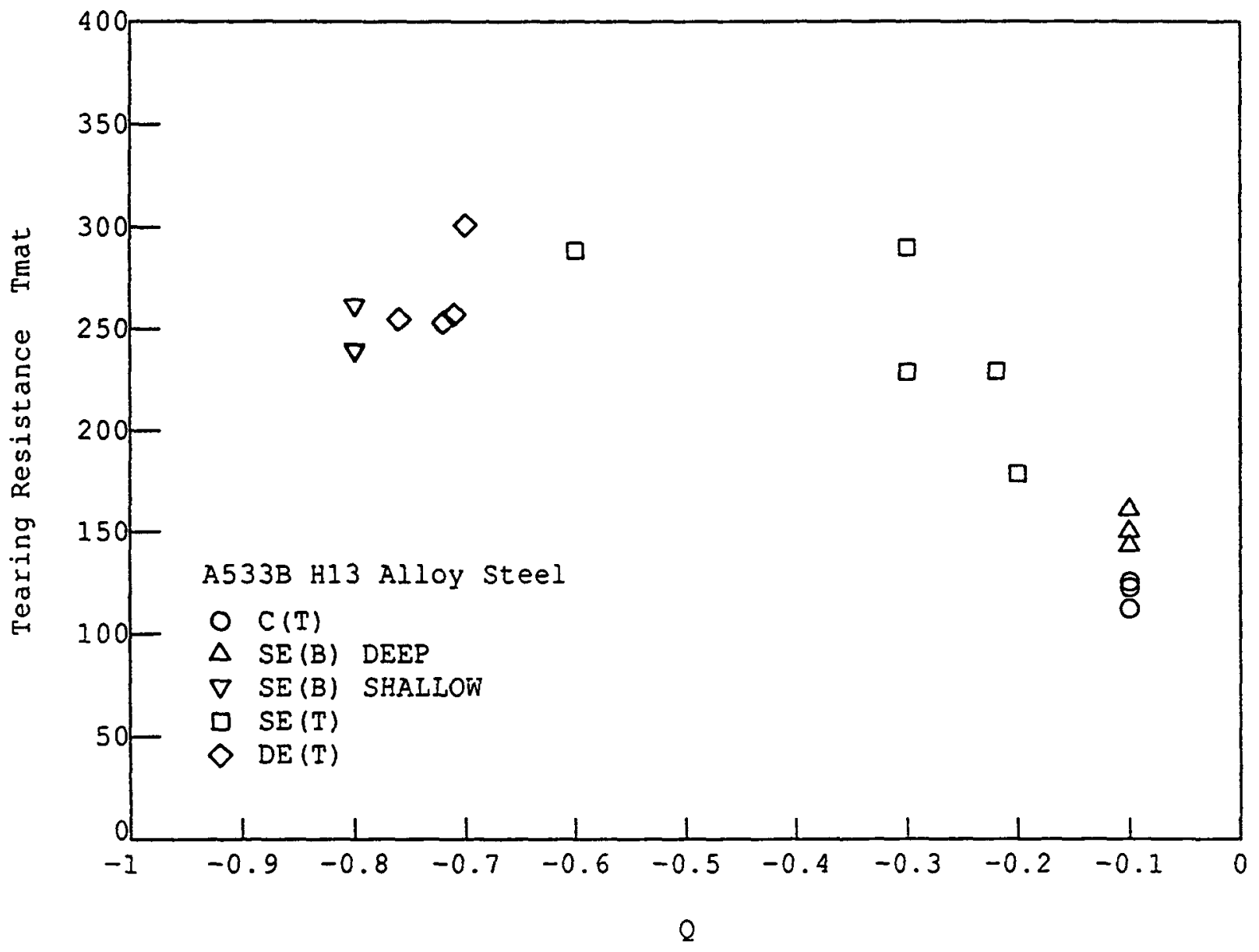

Figure 36 Tearing modulus, $\mathrm{T}_{\max }$, as a function of $\mathrm{Q}$ for the $\mathrm{A} 533 \mathrm{~B}$ specimens. 


\subsection{SUMMARY}

For these materials, at least, the $\mathrm{J}_{\mathrm{Ic}}$ toughness parameter is relatively insensitive to constraint as characterized by $T_{\sigma}$ or $Q$, while the tearing resistance is elevated by reduced constraint as measured by either $T_{\sigma}$ or $Q$. Thus the J-Q fracture locus is inconsequential for fully ductile behavior, but the $T_{\text {mat }}-Q$ locus is an important curve to measure the extent of toughness enhancement that would be expected under conditions of low constraint.

The best results for a low constraint specimen geometry are obtained from the short crack bend specimen. This specimen is now relatively easy to test in the laboratory, and has a low constraint by any measure, especially if the $\mathrm{a} / \mathrm{W}$ is less than 0.15 . It has been demonstrated (Kirk and Dodds, 1993) that the plastic $\eta$ for this geometry is dependent on the material strain hardening, and the suggestion has been made in the same work that the $J$ integral should be measured using the crack mouth opening displacement using Eq. (9) presented earlier. This analysis was applied to the specimens of this program, with a typical result shown in Figure 37. Three methods are plotted in Figure 37. The first analysis is the COD J integral calculated using Eq. (9), the second analysis uses the Sumpter $\eta$ analysis (1987), but does not apply the crack growth correction, and the third analysis uses the Sumpter $\eta$ and applies the crack growth correction, the method used in the work presented above. In the initiation area there is essentially no difference between the three methods. Beyond the early region, the COD J integral is elevated above the load-line $\mathrm{J}$ calculations. In the later part of the resistance curve the two non-crack growth corrected methods cross over, staying above the crack growth corrected analysis. The maximum difference in $\mathrm{J}$ values at any given crack extension is on the order of $10 \%$. It is not clear that there is any overriding reason to prefer any one of the three methods, though the use of a crack growth correction has strong analytical support, and has been used throughout this report. 


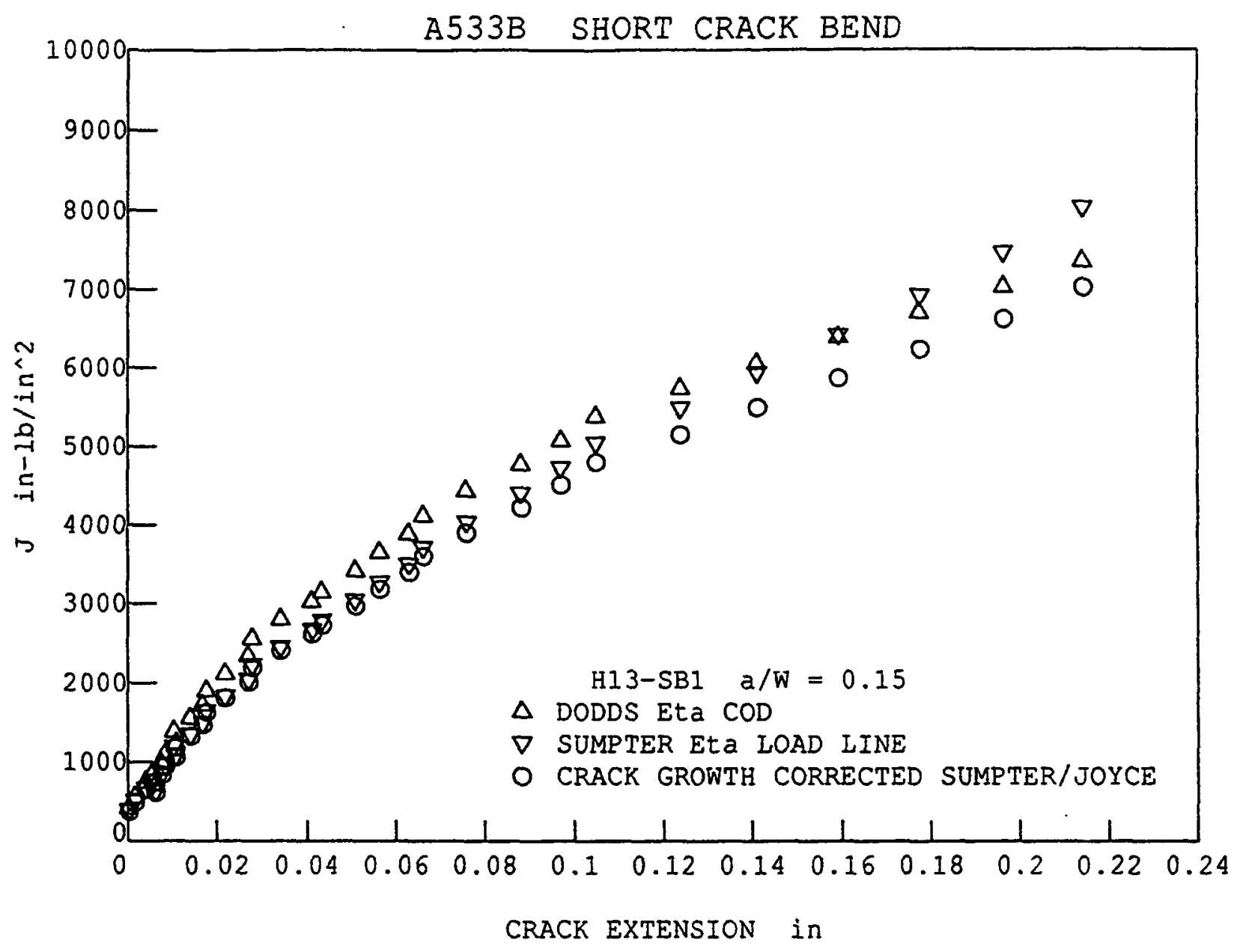

Figure 37 Comparison of J-Resistance curves calculated using three different $\mathrm{J}$ formulations. 


\subsection{CONCLUSIONS}

The following conclusions are drawn from this work:

1) A rotation correction is essential for obtaining an accurate $J_{I c}$ or J-R curve from a $S E(T)$ specimen of the type used in this work. The rotation correction developed here seems to greatly improve the appearance J-R curve.

2) $J_{\mathfrak{I}}$ does not seem to be dependent on constraint, as applied in this study, at least as characterized by $\mathrm{T}_{\sigma}$ or $\mathrm{Q}$.

3) The material tearing resistance, as characterized by $T_{\text {mal }}$, is strongly affected by constraint, with $T_{\text {mat }}$ increasing rapidly with decreasing constraint. This is true whether constraint is measured with $T_{\sigma}$ or $Q$.

4) The best low constraint test specimen geometry is the short crack bend specimen. Techniques have been developed which make it relatively easy to prepare and to test. 


\section{REFERENCES}

Al-Ani, A. M. and Hancock, J. W. (1991) "J-Dominance in Short Cracks in Tension and Bending", Journal of Mechanics and Physics of Solids, Vol. 39, pp. 23-43.

Anderson, T.L. and Dodds, R.H., Jr. (1991) "Specimen Size Requirements for Fracture Toughness Testing in the Transition Region," Journal of Testing and Evaluation, JTEVA, Vol. 19, No. 2, March 1991, pp. 123-134.

Betegón, C. and Hancock, J. W. (1991) "Two-Parameter Characterization of Elastic-Plastic Crack-Tip Fields", Journal of Applied Mechanics, Vol. 58, pp. 104-110.

Dodds, R.H., Jr., Anderson, T.L., and Kirk, M.T. (1991) "A Framework to Correlate a/W Ratio Effects on Elastic-plastic Fracture Toughness $\left(\mathrm{J}_{\mathrm{c}}\right)$," International Journal of Fracture, Vol. 48, pp. 1-22.

Hackett, E.M and Joyce, J.A. (1986) "Dynamic J-R Curve Testing of a High Strength Steel Using the Key Curve and Multi-Specimen Techniques," Fracture Mechanics, ASTM STP 905, American Society for Testing and Materials, Philadelphia, pp. 741-774.

Haigh, J.R. and Richards, C.E. (1974) "Yield Point Loads and Compliance Functions of Fracture Mechanics Specimens," CEGB Report RD/L/M461, Central Electricity Generating Board, UK.

Hutchinson, J. W. (1968) "Singular Behavior at the End of a Tensile Crack in a Hardening Material", Journal of Mechanics and Physics of Solids, Vol. 16, pp. 13-31.

Joyce, J.A., Hackett, E.M. and Roe, C. (1992) "Comparison of J $\mathrm{I}_{\mathrm{Ic}}$ and J-R Curves for Short Crack and Tensilely Loaded Specimen Geometries of a High Strength Structural Steel," NUREG/CR-5879, U.S. Nuclear Regulatory Commission, Washington D.C.

Joyce, J.A. (1992) "J-Resistance Curve Testing of Short Crack Bend Specimens Using Unloading Compliance," Fracture Mechanics: Twenty-Second Symposium (Volume I), ASTM STP 1131 , H.A. Ernst, A. Saxena, and D.L. McDowell, Eds., American Society for Testing and Materials, Philadelphia, pp. 904-924.

Kfouri, A.P. (1986) "Some Evaluations of the Elastic T-term using Eshelby's Method in International Journal of Fracture, Vol. 30, pp. 301-315.

Kirk, M.T. and Dodds, R.H., Jr. (1993) "J and CTOD Estimation Equations for Shallow Cracks in Single Edge Notch Bend Specimens," NUREG/CR-5969, U.S. Nuclear Regulatory Commission, Washington D.C. 
Kirk, M.T., and Dodds, R.H. (1991) "An Analytical and Experimental Comparison of Jo Values for Shallow Through and Part Through Surface Cracks," Engineering Fracture Mechanics, Vol. 39, No. 3, pp. 535-551.

Kirk, M. T., Koppenhoefer, K. C., and Shih, C. F. (1993) "Effect of Constraint on Specimen Dimensions Needed to Obtain Structurally Relevant Toughness Measures." Constraint Effects in Fracture, ASTM STP 1171, E. M. Hackett, et al., Eds., American Society for Testing and Materials, Philadelphia, pp. 79-103.

Kumar, V., German, M.D. and Shih, C.F. (1981) An Engineering Approach for Elastic-Plastic Fracture, EPRI NP-1931, Electric Power Research Institute, Palo Alto.

Larrson, S.G. and Carlsson, A.J. (1973) "Influence of Non-Singular Stress Terms and Specimen Geometry on Small-Scale Yielding at Crack tips in an Elastic-Plastic Material," Journal of Mechanics and Physics of Solids, Vol. 21, pp. 263-278.

Leevers, P. S. and Radon, J. C. (1982) "Inherent Stress Biaxiality in Various Fracture Specimen Geometries", International Journal of Fracture, Vol. 19, pp. 311-325.

O'Dowd, N.P., and Shih, C.F. (1992) "Family of Crack-Tip Fields Characterized by a Triaxiality Parameter: Part II - Fracture Applications," Journal of the Mechanics and Physics of Solids, Vol. 40, pp. 939-963.

O’Dowd, N.P. and Shih, C.F. (1991) "Family of Crack-Tip Fields Characterized by a Triaxiality Parameter - I. Structure of Fields," Journal of Mechanics and Physics of Solids, Vol. 39, pp. 989-1015.

Paris, P.C., Tada, H., Zahoor, A. and Ernst, H. (1979) "The Theory of Instability of the Tearing Mode of Elastic-Plastic Crack Growth," Elastic-Plastic Fracture, ASTM STP 668, J.D. Landes, et al., Eds., American Society for Testing and Materials, Philadelphia, pp. 5-36.

Rice, J. R. and Rosengren, G. F. (1968) "Plane Strain Deformation Near a Crack Tip in a Power-Law Hardening Material", Journal of Mechanics and Physics of Solids, Vol. 16, pp. 1-12.

Ritchie, R.O., Knott, J.F. and Rice, J.R. (1973) "On the Relationship Between Critical Fracture Stress and Fracture Toughness in Mild Steel', Journal of Mechanics and Physics of Solids, Vol. 21, pp. 395-410.

Sham, T. L. (1991) "The Determination of the Elastic T-Term Using Higher Order Weight Functions", International Journal of Fracture, Vol. 48, pp. 81-102. 
Sharobeam, M.H., Landes, J.D. and Herrera, R. (1991) "Development of $\eta F$ Factors in ElasticPlastic Testing Using a Load Separation Technique," Elastic-Plastic Fracture Test Methods - The User's Experience, ASTM STP 1114, J.A. Joyce, Ed., American Society for Testing and Materials, Philadelphia, pp. 114-132.

Sorem, W.A., Dodds, R H., and Rolfe, S.T. (1991) "Effects of Crack Depth on Elastic Plastic Fracture Toughness," International Journal of Fracture, Vol. 47, pp. 105-126.

Sumpter, J.D.G. (1987) "J $\mathrm{J}_{\mathrm{c}}$ Determination for Shallow Notch Welded Bend Specimens," Fatigue and Fracture of Engineering Materials and Structures, Vol. 10, No. 6, pp. 479-493.

Sumpter, J. D. G. and Forbes, A.T. (1992) "Constraint Based Analysis of Shallow Cracks in Mild Steel", Proceedings of TWI/EWI International. Conference on Shallow) Crack Fracture Mechanics, Toughness Tests and Applications, Cambridge, UK.

Tada, H., Paris, P.C. and Irwin, G.R. (1985) The Stress Analysis of Cracks Handbook, Paris Productions, Inc., St. Louis.

Williams, M. L. (1957) "On the Stress Distribution at the Base of a Stationary Crack", Journal of Applied Mechanics, Vol. 24, pp. 109-114.

Wu, S-X, Mai, Y-W and Cotterell, B. (1990) "Plastic $\eta$ Factors for Specimens With Deep and Shallow Cracks," International Journal of Fracture, Vol. 45, pp. 1-18. 


\section{APPENDIX A}

Data Tables for all Specimens 


\begin{tabular}{|c|c|c|c|c|c|c|c|c|c|c|c|}
\hline Specimen & & FYO-1 & & & & & & & & & \\
\hline $\begin{array}{c}\text { Unload } \\
\text { No. }\end{array}$ & $\begin{array}{c}\text { No. } \\
\text { Data } \\
\text { Points } \\
\end{array}$ & $\begin{array}{c}\text { Loadline } \\
\text { Slope } \\
\text { (lb/in) } \\
\end{array}$ & $\begin{array}{l}\text { COD } \\
\text { Slope } \\
\text { (lb/in) }\end{array}$ & Corr. & $\begin{array}{c}\text { Plastic } \\
\text { Area } \\
\text { (in-lb) }\end{array}$ & $\begin{array}{l}\text { Load } \\
\text { (ib.) }\end{array}$ & $\begin{array}{l}\text { Loadline } \\
\text { (in.) }\end{array}$ & $\begin{array}{l}\text { COD } \\
\text { (in.) }\end{array}$ & $\begin{array}{c}\text { Delta } \\
\text { a } \\
\text { (in.) }\end{array}$ & $\begin{array}{c}J \\
\left(\mathrm{in}-\mathrm{Ib} / \mathrm{in}^{2}\right)\end{array}$ & $\begin{array}{c}J \\
\text { Plastic } \\
\left(\mathrm{in}-\mathrm{lb} / \mathrm{in}^{2}\right)\end{array}$ \\
\hline 1 & 57 & 444087 & 565500 & 0.9997 & 0.2 & 5113.7 & 0.0091 & 0.0117 & -0.0008 & 50 & 0 \\
\hline 2 & 61 & 446769 & 565021 & 0.9998 & 2 & 7261.8 & 0.0133 & 0.0166 & -0.0006 & 104 & 3 \\
\hline 3 & 65 & 444157 & 563943 & 0.9998 & 8.6 & 9956.3 & 0.0191 & 0.0231 & 0 & 203 & 15 \\
\hline 4 & 66 & 444645 & 562307 & 0.9998 & 23 & 11986.3 & 0.0244 & 0.0291 & 0.0008 & 316 & 42 \\
\hline 5 & 63 & 443463 & 560680 & 0.9998 & 41.1 & 13017.5 & 0.0278 & 0.0329 & 0.0016 & 400 & 75 \\
\hline 6 & 67 & 443651 & 556389 & 0.9997 & 62.9 & 13718.8 & 0.0307 & 0.036 & 0.0037 & 477 & 115 \\
\hline 7 & 66 & 439995 & 553763 & 0.9997 & 86.7 & 14069 & 0.033 & 0.0386 & 0.0051 & 543 & 159 \\
\hline 8 & 71 & 438509 & 550207 & 0.9997 & 107 & 14355.9 & 0.0351 & 0.0408 & 0.0069 & 599 & 197 \\
\hline 9 & 72 & 434981 & 545380 & 0.9997 & 132.1 & 14508.5 & 0.0372 & 0.0431 & 0.0093 & 658 & 243 \\
\hline 10 & 72 & 430684 & 542519 & 0.9997 & 154.3 & 14599.5 & 0.0391 & 0.0451 & 0.0107 & 707 & 284 \\
\hline 11 & 69 & 428959 & 536099 & 0.9997 & 184.1 & 14607.2 & 0.0413 & 0.0474 & 0.014 & 769 & 339 \\
\hline 12 & 74 & 422901 & 527254 & 0.9997 & 218.1 & 14643.4 & 0.0436 & 0.05 & 0.0186 & 841 & 401 \\
\hline 13 & 73 & 415610 & 518697 & 0.9996 & 249.2 & 14490.1 & 0.0457 & 0.0522 & 0.0231 & 896 & 457 \\
\hline 14 & 75 & 404803 & 504889 & 0.9997 & 287.2 & 14364.6 & 0.0484 & 0.0551 & 0.0304 & 970 & 525 \\
\hline 15 & 75 & 400354 & 495443 & 0.9997 & 315.4 & 14252.3 & 0.0508 & 0.0576 & 0.0355 & 1024 & 575 \\
\hline 16 & 78 & 394360 & 486071 & 0.9996 & 348.2 & 14142.2 & 0.0531 & 0.0601 & 0.0406 & 1088 & 634 \\
\hline 17 & 75 & 389232 & 478931 & 0.9997 & 380 & 14039 & 0.0555 & 0.0625 & 0.0445 & 1147 & 693 \\
\hline 18 & 73 & 380141 & 467573 & 0.9996 & 417.8 & 13845.8 & 0.0581 & 0.0653 & 0.0509 & 1217 & 761 \\
\hline 19 & 68 & 374372 & 458804 & 0.9996 & 462.2 & 13662.2 & 0.0614 & 0.0688 & 0.0558 & 1300 & 843 \\
\hline 20 & 69 & 369337 & 450882 & 0.9996 & 497.6 & 13611 & 0.0642 & 0.0718 & 0.0604 & 1371 & 909 \\
\hline 21 & 73 & 360018 & 440192 & 0.9996 & 543.1 & 13408.1 & 0.0673 & 0.0752 & 0.0666 & 1453 & 992 \\
\hline 22 & 71 & 351862 & 426851 & 0.9995 & 590 & 13132.5 & 0.0707 & 0.0788 & 0.0745 & 1536 & 1075 \\
\hline 23 & 74 & 343831 & 415952 & 0.9996 & 632.1 & 12909 & 0.074 & 0.0822 & 0.081 & 1612 & 1151 \\
\hline 24 & 64 & 335094 & 404764 & 0.9994 & 680.7 & 12660.2 & 0.0777 & 0.0863 & 0.0879 & 1701 & 1239 \\
\hline 25 & 64 & 327012 & 390486 & 0.9993 & 735.7 & 12332.2 & 0.0818 & 0.0906 & 0.0969 & 1792 & 1337 \\
\hline 26 & 61 & 316169 & 377488 & 0.9994 & 781.5 & 11992.1 & 0.0853 & 0.0943 & 0.1052 & 1870 & 1416 \\
\hline 27 & 62 & 307834 & 365461 & 0.9994 & 827.6 & 11701.2 & 0.0893 & 0.0983 & 0.1131 & 1946 & 1497 \\
\hline 28 & 71 & 297717 & 352996 & 0.9994 & 877.1 & 11499.2 & 0.0936 & 0.103 & 0.1214 & 2037 & 1585 \\
\hline 29 & 66 & 291365 & 343519 & 0.9993 & 913.7 & 11179.6 & 0.097 & 0.1064 & 0.1279 & 2094 & 1649 \\
\hline 30 & 69 & 284592 & 333126 & 0.9993 & 955.2 & 10938.4 & 0.1006 & 0.1101 & 0.1351 & 2167 & 1721 \\
\hline 31 & 71 & 276681 & 323079 & 0.9993 & 996.3 & 10673.4 & 0.1042 & 0.1137 & 0.1422 & 2233 & 1793 \\
\hline 32 & 74 & 266852 & 310320 & 0.9993 & 1045.9 & 10412.6 & 0.1088 & 0.118 .5 & 0.1515 & 2318 & 1878 \\
\hline
\end{tabular}




\begin{tabular}{|c|c|c|c|c|c|c|c|c|c|c|c|}
\hline $\begin{array}{c}\text { Unload } \\
\text { No. }\end{array}$ & $\begin{array}{c}\text { No. } \\
\text { Data } \\
\text { Points }\end{array}$ & $\begin{array}{c}\text { Loadline } \\
\text { Slope } \\
\text { (lb/in) }\end{array}$ & $\begin{array}{l}\text { COD } \\
\text { Slope } \\
\text { (lb/in) }\end{array}$ & Corr. & $\begin{array}{c}\text { Plastic } \\
\text { Area } \\
(\text { in-lb) }\end{array}$ & $\begin{array}{l}\text { Load } \\
\text { (lb.) }\end{array}$ & Loadline & COD & $\begin{array}{c}\text { Delta } \\
\text { a } \\
\text { (in.) }\end{array}$ & $\begin{array}{c}J \\
\left(i n-l b / i n^{2}\right)\end{array}$ & $\begin{array}{c}J \\
\text { Plastic } \\
\left(\mathrm{in}-\mathrm{lb} / \mathbf{i n}^{2}\right) \\
\end{array}$ \\
\hline 1 & 77 & 454949 & 567618 & 0.9999 & 0.5 & 5011.3 & 0.0085 & 0.0106 & -0.0004 & 47 & 0 \\
\hline 2 & 67 & 461483 & 568609 & 0.9999 & 2.5 & 7410.6 & 0.013 & 0.0162 & -0.0009 & 107 & 3 \\
\hline 3 & 97 & 459290 & 566837 & 0.9999 & 11.7 & 9880.8 & 0.0182 & 0.0224 & 0 & 204 & 20 \\
\hline 4 & 102 & 461647 & 565221 & 0.9999 & 34.4 & 12235 & 0.0243 & 0.0295 & 0.0008 & 344 & 62 \\
\hline 5 & 75 & 460135 & 564787 & 0.9998 & 53.3 & 13012.3 & 0.0268 & 0.0326 & 0.001 & 416 & 96 \\
\hline 6 & 76 & 460169 & 562497 & 0.9998 & 76.6 & 13815.9 & 0.0298 & 0.0362 & 0.0021 & 502 & 139 \\
\hline 7 & 74 & 459611 & 562099 & 0.9998 & 88.1 & 14089 & 0.0311 & 0.0376 & 0.0023 & 536 & 161 \\
\hline 8 & 75 & 458699 & 559824 & 0.9998 & 102.7 & 14337.8 & 0.0325 & 0.0392 & 0.0035 & 578 & 187 \\
\hline 9 & 72 & 457490 & 557583 & 0.9998 & 124.5 & 14600.3 & 0.0343 & 0.0413 & 0.0046 & 636 & 227 \\
\hline 10 & 73 & 454562 & 554541 & 0.9998 & 144.3 & 14832.7 & 0.036 & 0.0432 & 0.0061 & 687 & 264 \\
\hline 11 & 76 & 450524 & 549823 & 0.9998 & 172.8 & 15028.3 & 0.0383 & 0.0457 & 0.0085 & 753 & 316 \\
\hline 12 & 75 & 447639 & 546654 & 0.9997 & 196.7 & 15029.3 & 0.0399 & 0.0476 & 0.0101 & 802 & 359 \\
\hline 13 & 79 & 444623 & 541300 & 0.9997 & 227.2 & 15169.2 & 0.0422 & 0.0502 & 0.0128 & 870 & 415 \\
\hline 14 & 84 & 438252 & 533768 & 0.9998 & 264.4 & 15068.3 & 0.0445 & 0.0527 & 0.0167 & 941 & 482 \\
\hline 15 & 76 & 436064 & 527170 & 0.9997 & 298.6 & 15122.2 & 0.047 & 0.0555 & 0.0201 & 1012 & 545 \\
\hline 16 & 77 & 427877 & 518799 & 0.9997 & 341.8 & 15015.7 & 0.0496 & 0.0582 & 0.0244 & 1093 & 623 \\
\hline 17 & 78 & 421652 & 509486 & 0.9997 & 383.4 & 14888.8 & 0.0526 & 0.0614 & 0.0294 & 1171 & 698 \\
\hline 18 & 82 & 416640 & 498962 & 0.9997 & 427.4 & 14806.2 & 0.0556 & 0.0646 & 0.035 & 1257 & 776 \\
\hline 19 & 77 & 411182 & 492954 & 0.9997 & 462.5 & 14656.5 & 0.0579 & 0.0671 & 0.0382 & 1320 & 841 \\
\hline 20 & 75 & 404632 & 483026 & 0.9997 & 508.2 & 14522 & 0.0609 & 0.0703 & 0.0437 & 1406 & 923 \\
\hline 21 & 79 & 395310 & 471938 & 0.9997 & 551.6 & 14405 & 0.0639 & 0.0735 & 0.0498 & 1485 & 999 \\
\hline 22 & 81 & 384127 & 456363 & 0.9996 & 601.1 & 14023.4 & 0.0672 & 0.0769 & 0.0586 & 1566 & 1083 \\
\hline 23 & 78 & 374807 & 443503 & 0.9996 & 644.2 & 13798.5 & 0.0705 & 0.0804 & 0.066 & 1641 & 1157 \\
\hline 24 & 80 & 369581 & 435772 & 0.9996 & 670.1 & 13584.5 & 0.0727 & 0.0826 & 0.0706 & 1682 & 1201 \\
\hline 25 & 84 & 361607 & 424851 & 0.9996 & 717.6 & 13398.8 & 0.076 & 0.0861 & 0.0771 & 1768 & 1286 \\
\hline 26 & 83 & 352066 & 413833 & 0.9995 & 756.8 & 13059.7 & 0.0788 & 0.0889 & 0.0837 & 1828 & 1353 \\
\hline 27 & 84 & 342993 & 401200 & 0.9996 & 798.8 & 12793.7 & 0.0821 & 0.0923 & 0.0915 & 1899 & 1423 \\
\hline 28 & 87 & 334721 & 389698 & 0.9996 & 843.5 & 12564.5 & 0.0857 & 0.0961 & 0.0987 & 1976 & 1501 \\
\hline 29 & 91 & 326310 & 379650 & 0.9995 & 885.8 & 12342.6 & 0.0892 & 0.0997 & 0.1051 & 2049 & 1575 \\
\hline 30 & 91 & 317061 & 367090 & 0.9995 & 936.7 & 12078.3 & 0.0933 & 0.1039 & 0.1133 & 2135 & 1663 \\
\hline 31 & 91 & 307986 & 356040 & 0.9995 & 980.5 & 11784.6 & 0.097 & 0.1078 & 0.1207 & 2206 & 1738 \\
\hline 32 & 92 & 297146 & 341815 & 0.9994 & 1028.6 & 11317.6 & 0.1008 & 0.1114 & 0.1304 & 2272 & 1815 \\
\hline 33 & 92 & 285027 & 326534 & 0.9993 & 1089.6 & 10948.5 & 0.1062 & 0.117 & 0.1411 & 2372 & 1918 \\
\hline
\end{tabular}




\begin{tabular}{|c|c|c|c|c|c|c|c|c|c|c|c|}
\hline Specimen & & FYO-3 & & & & & & & & & \\
\hline $\begin{array}{c}\text { Unload } \\
\text { No. }\end{array}$ & $\begin{array}{c}\text { No. } \\
\text { Data } \\
\text { Points } \\
\end{array}$ & $\begin{array}{c}\text { Loadline } \\
\text { Slope } \\
\text { (lb/in) }\end{array}$ & $\begin{array}{l}\text { COD } \\
\text { Slope } \\
\text { (lb/in) }\end{array}$ & Corr. & $\begin{array}{c}\text { Plastic } \\
\text { Area } \\
(\text { in-lb) } \\
\end{array}$ & $\begin{array}{l}\text { Load } \\
\text { (lb.) }\end{array}$ & Loadline & $\begin{array}{l}\text { COD } \\
\text { (in.) }\end{array}$ & $\begin{array}{c}\text { Delta } \\
\text { a } \\
\text { (in.) }\end{array}$ & $\begin{array}{c}J \\
\left(\mathrm{in}-\mathrm{lb} / \mathrm{in}^{2}\right) \\
\end{array}$ & $\begin{array}{c}\text { J } \\
\text { Plastic } \\
\left(\text { in-lb/in }{ }^{2}\right)\end{array}$ \\
\hline 34 & 96 & 274768 & 312869 & 0.9994 & 1137.4 & 10609.1 & 0.1108 & 0.1217 & 0.1509 & 2444 & 1993 \\
\hline 35 & 102 & 264175 & 298838 & 0.9993 & 1187.6 & 10271.6 & 0.1157 & 0.1267 & 0.1613 & 2521 & 2072 \\
\hline 36 & 105 & 250078 & 282489 & 0.9993 & 1249.9 & 9821.7 & 0.1216 & 0.1327 & 0.1738 & 2614 & 2171 \\
\hline 37 & 109 & 237851 & 267536 & 0.9993 & 1305.6 & 9423.5 & 0.1278 & 0.1389 & 0.1857 & 2692 & 2256 \\
\hline
\end{tabular}




\begin{tabular}{|c|c|c|c|c|c|c|c|c|c|c|c|}
\hline pecimen & & FYO & & & & & & & & & \\
\hline $\begin{array}{l}\text { Unload } \\
\text { No. }\end{array}$ & $\begin{array}{c}\text { No. } \\
\text { Data } \\
\text { Points }\end{array}$ & $\begin{array}{c}\text { Loadline } \\
\text { Slope } \\
\text { (Ib/in) }\end{array}$ & $\begin{array}{l}\text { COD } \\
\text { Slope } \\
(\text { lb/in) }\end{array}$ & Corr. & $\begin{array}{c}\text { Plastic } \\
\text { Area } \\
(\text { in-lb) }\end{array}$ & $\begin{array}{l}\text { Load } \\
\text { (lb.) }\end{array}$ & $\begin{array}{l}\text { Loadline } \\
\text { (iin.) }\end{array}$ & $\begin{array}{l}\text { COD } \\
\text { (in.) }\end{array}$ & $\begin{array}{c}\text { Delta } \\
\text { a } \\
\text { (in.) }\end{array}$ & $\begin{array}{c}J \\
\left(\mathrm{in}-\mathrm{lb} / \mathrm{in}^{2}\right)\end{array}$ & $\begin{array}{c}\text { J } \\
\text { Plastic } \\
\left(\mathrm{in}-\mathrm{lb} / \mathbf{i n}^{2}\right)\end{array}$ \\
\hline 1 & 62 & 2600303.8 & 11908627.4 & 0.99999 & -14.1 & 40343.4 & 0.0034 & 0.01206 & -0.0005 & 116.7 & -6.7 \\
\hline 2 & 43 & 2598908.9 & 11843644.1 & 0.99996 & 35.5 & 60575.6 & 0.00562 & 0.02192 & 0.00093 & 292.9 & 16.9 \\
\hline 3 & 55 & 2598962.2 & 11710230.8 & 0.99996 & 220.9 & 77163 & 0.0084 & 0.03029 & 0.00389 & 555.9 & 105.7 \\
\hline 4 & 55 & 2577295.1 & 11344671.4 & 0.99989 & 629.4 & 88180.6 & 0.01165 & 0.03987 & 0.01233 & 903.2 & 308.5 \\
\hline 5 & 120 & 2552456.6 & 11113895.5 & 0.99986 & 875.6 & 91672.6 & 0.01337 & 0.03893 & 0.0179 & 1090 & 433.7 \\
\hline 6 & 54 & 2553651.4 & 11148821.4 & 0.99992 & 939.8 & 91938 & 0.01448 & 0.03898 & 0.01704 & 1151.2 & 464.3 \\
\hline 7 & 66 & 2548377.8 & 11036296.3 & 0.99994 & 1121.2 & 92701.8 & 0.01547 & 0.04102 & 0.01981 & 1270.5 & 556.5 \\
\hline 8 & 83 & 2521481.7 & 10652450.6 & 0.99975 & 1464.2 & 96779.8 & 0.01696 & 0.04572 & 0.02963 & 1503.6 & 742.3 \\
\hline 9 & 74 & 2505045.2 & 10488722.1 & 0.99992 & 1705.7 & 96011 & 0.01886 & 0.0484 & 0.034 & 1661.4 & 871.6 \\
\hline 10 & 78 & 2457043.6 & 9832096.4 & 0.99961 & 2189.7 & 98767.4 & 0.02091 & 0.05364 & 0.05269 & 2004.6 & 1164.8 \\
\hline 11 & 76 & 2430679.5 & 9632467.5 & 0.9998 & 2422 & 98703 & 0.0225 & 0.06228 & 0.05877 & 2157.6 & 1302.7 \\
\hline 12 & 66 & 2415080.5 & 9387499.5 & 0.99978 & 2622.2 & 98006.4 & 0.02398 & 0.05908 & 0.0665 & 2301.1 & 1430.8 \\
\hline 13 & 88 & 2372732.6 & 8990594.4 & 0.99939 & 2920.1 & 98419.6 & 0.02554 & 0.06846 & 0.07972 & 2525.5 & 1634.2 \\
\hline 14 & 66 & 2334989.7 & 8628172.6 & 0.99957 & 3096.3 & 97423.8 & 0.02728 & 0.06445 & 0.09257 & 2694.6 & 1775 \\
\hline 15 & 66 & 2310595.3 & 8334677.1 & 0.99976 & 3400 & 97035.8 & 0.02883 & 0.07539 & 0.10359 & 2902.3 & 1990.4 \\
\hline 16 & 79 & 2251070.2 & 7902822.4 & 0.99969 & 3691.5 & 95766 & 0.03069 & 0.07661 & 0.12086 & 3180.4 & 2234.6 \\
\hline 17 & 65 & 2213380.3 & 7581352.8 & 0.99962 & 3881.6 & 94332.2 & 0.03232 & 0.07845 & 0.13461 & 3372.9 & 2412.5 \\
\hline 18 & 83 & 2197824.7 & 7056580.4 & 0.99946 & 4104.5 & 92980.6 & 0.03405 & 0.07778 & 0.15889 & 3665.6 & 2677.2 \\
\hline 19 & 52 & 2147274.6 & 6765973.7 & 0.99962 & 4269.8 & 91138.2 & 0.03514 & 0.07988 & 0.1734 & 3862.9 & 2867.8 \\
\hline 20 & 76 & 2118415.4 & 6553691.6 & 0.9997 & 4349.4 & 89855.6 & 0.03615 & 0.08494 & 0.18454 & 3971.5 & 2988 \\
\hline 21 & 65 & 2077551.6 & 6155706.7 & 0.99947 & 4509.6 & 88436.4 & 0.03745 & 0.08068 & 0.20673 & 4268.5 & 3248.1 \\
\hline
\end{tabular}




\begin{tabular}{|c|c|c|c|c|c|c|c|c|c|c|c|}
\hline Specimen & & -26 & & & & & & & & & \\
\hline $\begin{array}{l}\text { Unload } \\
\text { No. }\end{array}$ & $\begin{array}{c}\text { No. } \\
\text { Data } \\
\text { Points }\end{array}$ & $\begin{array}{l}\text { Loadline } \\
\text { Slope } \\
\text { (lb/in) }\end{array}$ & $\begin{array}{l}\text { COD } \\
\text { Slope } \\
\text { (lb/in) }\end{array}$ & Corr. & $\begin{array}{c}\text { Plastic } \\
\text { Area } \\
(\text { in-lb) }\end{array}$ & $\begin{array}{l}\text { Load } \\
\text { (lb.) }\end{array}$ & $\begin{array}{l}\text { Loadline } \\
\text { (in.) }\end{array}$ & $\begin{array}{l}\text { COD } \\
\text { (in.) }\end{array}$ & $\begin{array}{c}\text { Delta } \\
\text { a } \\
\text { (in.) }\end{array}$ & $\begin{array}{c}J \\
\left(\mathrm{in}-\mathrm{lb} / \mathrm{in}^{2}\right)\end{array}$ & $\begin{array}{c}\text { J } \\
\text { Plastic } \\
\left(\mathrm{in}-\mathrm{lb} / \mathrm{in}^{2}\right)\end{array}$ \\
\hline 1 & 91 & 1341080 & 6239362.4 & 0.99985 & -1.3 & 19646.2 & 0.00316 & 0.01465 & 0.00056 & 115.6 & -1.2 \\
\hline 2 & 102 & 1351762.7 & 6230853.6 & 0.99987 & 18.8 & 29200.1 & 0.00515 & 0.02231 & 0.0009 & 264.2 & 17.3 \\
\hline 3 & 99 & 1332551.3 & 6182362.9 & 0.99985 & 72.7 & 35418.9 & 0.00702 & 0.02852 & 0.00287 & 439.5 & 67.4 \\
\hline 4 & 99 & 1317869.1 & 6127514.2 & 0.99981 & 125.1 & 38907.6 & 0.00846 & 0.03288 & 0.00513 & 567.7 & 116.5 \\
\hline 5 & 94 & 1318290.8 & 6062193.5 & 0.99976 & 182.6 & 41242.5 & 0.00979 & 0.0364 & 0.00787 & 670.5 & 171.1 \\
\hline 6 & 96 & 1315963.6 & 5997058.7 & 0.99975 & 257.3 & 42901 & 0.01094 & 0.03931 & 0.01065 & 798.3 & 242.6 \\
\hline 7 & 96 & 1309412 & 5929210.5 & 0.9997 & 316.3 & 44043.9 & 0.01188 & 0.04168 & 0.0136 & 876.5 & 300.1 \\
\hline 8 & 96 & 1303162.2 & 5837405.9 & 0.99969 & 383.3 & 44957.5 & 0.01293 & 0.0441 & 0.01769 & 975.3 & 367 \\
\hline 9 & 96 & 1299696.7 & 5744028 & 0.99971 & 479.6 & 45945.4 & 0.01426 & 0.04713 & 0.02197 & 1107.2 & 463.5 \\
\hline 10 & 93 & 1295487.4 & 5670929.8 & 0.99966 & 559.8 & 46386.6 & 0.01533 & 0.04922 & 0.0254 & 1211 & 544.9 \\
\hline 11 & 93 & 1286007.2 & 5548891.3 & 0.9996 & 647.8 & 47010.7 & 0.0165 & 0.0518 & 0.03129 & 1331.2 & 638.4 \\
\hline 12 & 93 & 1275984.1 & 5349942.2 & 0.99953 & 757 & 47112.5 & 0.01797 & 0.05445 & 0.04139 & 1484.1 & 762.2 \\
\hline 13 & 92 & 1270185.3 & 5219969.9 & 0.99957 & 832.1 & 47325 & 0.01906 & 0.05645 & 0.04832 & 1603.3 & 849.4 \\
\hline 14 & 93 & 1256704.7 & 5077040.1 & 0.99962 & 916.9 & 47317.9 & 0.02019 & 0.0584 & 0.05628 & 1712.8 & 950.8 \\
\hline 15 & 94 & 1242517.6 & 4824389.3 & .0 .99957 & 1015.2 & 47115 & 0.02169 & 0.0607 & 0.07126 & 1873.4 & 1084.4 \\
\hline 16 & 86 & 1216405.9 & 4438143.7 & 0.99951 & 1160.6 & 46175.8 & 0.02384 & 0.06349 & 0.09669 & 2136 & 1304.6 \\
\hline 17 & 88 & 1202108 & 4236000.4 & 0.99955 & 1230 & 45900.9 & 0.02529 & 0.06556 & 0.11137 & 2257.5 & 1421.4 \\
\hline
\end{tabular}




\begin{tabular}{|c|c|c|c|c|c|c|c|c|c|c|c|}
\hline $\begin{array}{c}\text { Unload } \\
\text { No. }\end{array}$ & $\begin{array}{c}\text { No. } \\
\text { Data } \\
\text { Points } \\
\end{array}$ & $\begin{array}{c}\text { Loadline } \\
\text { Slope } \\
\text { (lb/in) }\end{array}$ & $\begin{array}{l}\text { COD } \\
\text { Slope } \\
(\mathrm{lb} / \mathrm{in}) \\
\end{array}$ & Corr. & $\begin{array}{c}\text { Plastic } \\
\text { Area } \\
(\text { in-lb) }\end{array}$ & Load & Loadline & COD & $\begin{array}{c}\text { Delta } \\
\text { a } \\
\text { (in.) }\end{array}$ & $\left(\mathrm{in}-\mathrm{lb} / \mathrm{in}^{2}\right)$ & $\begin{array}{c}J \\
\text { Plastic } \\
\left(\mathrm{in}-\mathrm{lb} / \mathrm{in}^{2}\right)\end{array}$ \\
\hline 1 & 94 & 1319160.6 & 6219615.4 & 0.99983 & -2.5 & 19631.7 & 0.0032 & 0.01508 & 0.00036 & 110.3 & -2.3 \\
\hline 2 & 102 & 1349910.6 & 6228824.4 & 0.99983 & 10.8 & 29256.9 & 0.00523 & 0.02261 & -0.00001 & 256.2 & 9.9 \\
\hline 3 & 99 & 1328226.4 & 6206841.7 & 0.99987 & 52.1 & 33307.9 & 0.00637 & 0.02638 & 0.00087 & 378.3 & 48 \\
\hline 4 & 99 & 1327370.6 & 6195222.1 & 0.99982 & 62.5 & 35819.5 & 0.00723 & 0.02906 & 0.00135 & 439.3 & 57.7 \\
\hline 5 & 97 & 1330019.6 & 6185832.1 & 0.99982 & 89.4 & 37642.1 & 0.00793 & 0.03105 & 0.00173 & 502.8 & 82.6 \\
\hline 6 & 96 & 1325862.1 & 6161016.5 & 0.99975 & 120.5 & 39030.6 & 0.00857 & 0.03289 & 0.00275 & 553.6 & 111.6 \\
\hline 7 & 96 & 1329412.1 & 6139346.4 & 0.99973 & 147.7 & 40228.7 & 0.0092 & 0.03463 & 0.00364 & 619.9 & 137 \\
\hline 8 & 96 & 1323237.2 & 6112482.9 & 0.99973 & 187.1 & 41229.4 & 0.00983 & 0.03623 & 0.00475 & 669.7 & 174.1 \\
\hline 9 & 96 & 1320801 & 6068088 & 0.99973 & 220.7 & 42335.7 & 0.01053 & 0.03805 & 0.00662 & 731.5 & 206.1 \\
\hline 10 & 96 & 1315273.8 & 6011221.3 & 0.9997 & 268.6 & 43313.5 & 0.01131 & 0.03993 & 0.00904 & 817.5 & 252.3 \\
\hline 11 & 96 & 1312844.5 & 5966994.1 & 0.99968 & 320.2 & 44028.3 & 0.01214 & 0.04174 & 0.01095 & 879.5 & 302.1 \\
\hline 12 & 95 & 1303893.6 & 5889593.7 & 0.99969 & 378.2 & 44902.6 & 0.01297 & 0.04384 & 0.01435 & 962.7 & 359.5 \\
\hline 13 & 95 & 1307925 & 5831290.5 & 0.99966 & 434.2 & 45634.6 & 0.01385 & 0.04586 & 0.01697 & 1042.2 & 415.1 \\
\hline 14 & 95 & 1298678.1 & 5799731.3 & 0.99964 & 507.9 & 46155.7 & 0.01476 & 0.04776 & 0.0184 & 1132.6 & 487 \\
\hline 15 & 91 & 1296438.4 & 5745705.4 & 0.99959 & 569.8 & 46567 & 0.01566 & 0.04966 & 0.02089 & 1215.4 & 549.2 \\
\hline 16 & 93 & 1290539.3 & 5681632.2 & 0.99955 & 652 & 47224.8 & 0.01669 & 0.05202 & 0.02389 & 1319.7 & 632.5 \\
\hline 17 & 94 & 1287767.9 & 5598529 & 0.999 .56 & 734 & 47461.5 & 0.01774 & 0.05411 & 0.02787 & 1423.3 & 718.1 \\
\hline 18 & 95 & 1277990 & 5528805.7 & 0.99957 & 823.7 & 47888.3 & 0.01886 & 0.05632 & 0.03129 & 1534.9 & 811.5 \\
\hline 19 & 94 & 1277798.4 & 5445077.9 & 0.99959 & 902.3 & 48095 & 0.01989 & 0.05842 & 0.03548 & 1633.8 & 896.6 \\
\hline 20 & 94 & 1274700.4 & 5356337.6 & 0.99953 & 995.2 & 48345.4 & 0.02099 & 0.0606 & 0.04005 & 1752.3 & 998.2 \\
\hline 21 & 93 & 1266187.7 & 5225851.4 & 0.9994 & 1112.8 & 48264.8 & 0.02238 & 0.06304 & 0.047 & 1904.1 & 1132.2 \\
\hline 22 & 91 & 1253507.6 & 5093526.6 & 0.99942 & 1224.7 & 48253 & 0.0238 & 0.06559 & 0.05435 & 2055.1 & 1264.5 \\
\hline 23 & 90 & 1244213.1 & 4926743.8 & 0.99946 & 1339.7 & 48158.2 & 0.02536 & 0.06825 & 0.06405 & 2235.2 & 1410.2 \\
\hline 24 & 91 & 1238065.4 & 4790891.8 & 0.99941 & 1432.6 & 48071.3 & 0.02662 & 0.07039 & 0.07234 & 2358.3 & 1532.3 \\
\hline 25 & 90 & 1218301.4 & 4573471.2 & 0.99938 & 1559.6 & 47544.9 & 0.02825 & 0.07277 & 0.08641 & 2555.7 & 1714.5 \\
\hline 26 & 88 & 1208249.2 & 4410676.7 & 0.99945 & 1641.6 & 47161.8 & 0.02965 & 0.07483 & 0.09762 & 2713.3 & 1843.3 \\
\hline 27 & 90 & 1191990.8 & 4188342.5 & 0.99938 & 1765.7 & 46517.4 & 0.03139 & 0.07724 & 0.11398 & 2931.7 & 2046.4 \\
\hline 28 & 92 & 1170423.7 & 3965836.2 & 0.99939 & 1884.1 & 45946.6 & 0.0333 & 0.07991 & 0.13167 & 3145.7 & 2259.8 \\
\hline 29 & 93 & 1155780.1 & 3825107 & 0.99939 & 1960.1 & 45521.9 & 0.03473 & 0.08188 & 0.1436 & 3302.1 & 2405.5 \\
\hline 30 & 88 & 1139695.4 & 3605203.9 & 0.99933 & 2077.7 & 44361 & 0.03654 & 0.08389 & 0.16352 & 3554.7 & 2653.2 \\
\hline 31 & 86 & 1116530.2 & 3395362.3 & 0.99938 & 2173 & 43454.2 & 0.03823 & 0.08583 & 0.18414 & 3806.3 & 2893.5 \\
\hline
\end{tabular}




\begin{tabular}{|c|c|c|c|c|c|c|c|c|c|c|c|}
\hline Specimen & & FYO- 150 & & & & & & & & & \\
\hline $\begin{array}{c}\text { Unload } \\
\text { No. }\end{array}$ & $\begin{array}{c}\text { No. } \\
\text { Data } \\
\text { Points } \\
\end{array}$ & $\begin{array}{c}\text { Loadline } \\
\text { Slope } \\
\text { (lb/in) } \\
\end{array}$ & $\begin{array}{l}\text { COD } \\
\text { Slope } \\
\text { (lb/in) } \\
\end{array}$ & Corr. & $\begin{array}{c}\text { Plastic } \\
\text { Area } \\
(i n-l b)\end{array}$ & $\begin{array}{l}\text { Load } \\
\text { (lb.) }\end{array}$ & $\begin{array}{l}\text { Loadline } \\
\text { (in.) }\end{array}$ & $\begin{array}{l}\text { COD } \\
\text { (in.) }\end{array}$ & $\begin{array}{c}\text { Delta } \\
\text { a } \\
\text { (in.) }\end{array}$ & $\begin{array}{c}J \\
\left(\mathrm{in}-\mathrm{lb} / \mathrm{in}^{2}\right) \\
\end{array}$ & $\begin{array}{c}J \\
\text { Plastic } \\
\left(\text { in- } \mid \mathrm{lb}_{\mathrm{in}}{ }^{2}\right)\end{array}$ \\
\hline 1 & 65 & 299916 & 405092 & 0.9998 & 0 & 4380.4 & 0.0105 & 0.014 & -0.0012 & 94 & 0 \\
\hline 2 & 59 & 299320 & 404.585 & 0.9998 & 1.7 & 6262.2 & 0.0158 & 0.0207 & -0.0008 & 198 & 5 \\
\hline 3 & 57 & 297795 & 404145 & 0.9998 & 9 & 7530.1 & 0.0201 & 0.0261 & -0.0005 & 308 & 29 \\
\hline 4 & 63 & 297799 & 401300 & 0.9997 & 25 & 8568.7 & 0.0247 & 0.0318 & 0.0017 & 444 & 80 \\
\hline 5 & 64 & 297172 & 398216 & 0.9997 & 38.5 & 8973.9 & 0.0272 & 0.0345 & 0.0041 & 521 & 123 \\
\hline 6 & 63 & 294835 & 395412 & 0.9997 & 51 & 9278 & 0.0293 & 0.0371 & 0.0063 & 595 & 163 \\
\hline 7 & 63 & 292424 & 393654 & 0.9997 & 61.9 & 9529.7 & 0.0313 & 0.0394 & 0.0076 & 656 & 198 \\
\hline 8 & 63 & 291889 & 390527 & 0.9997 & 74 & 9721.7 & 0.0331 & 0.0414 & 0.0101 & 716 & 237 \\
\hline 9 & 61 & 289685 & 387094 & 0.9997 & 88.2 & 9775.3 & 0.0347 & 0.0433 & 0.0128 & 775 & 282 \\
\hline 10 & 62 & 287085 & 382539 & 0.9996 & 102.7 & 9883.5 & 0.0366 & 0.0453 & 0.0165 & 836 & 329 \\
\hline 11 & 61 & 282226 & 377412 & 0.9996 & 118.7 & 9908.2 & 0.0384 & 0.0472 & 0.0206 & 895 & 379 \\
\hline 12 & 63 & 278833 & 371893 & 0.9996 & 133.5 & 9929.2 & 0.0403 & 0.0496 & 0.0251 & 958 & 426 \\
\hline 13 & 62 & 276834 & 368195 & 0.9996 & 149 & 9951.9 & 0.0421 & 0.0516 & 0.0281 & 1017 & 475 \\
\hline 14 & 64 & 273208 & 362804 & 0.9995 & 167.4 & 9936.4 & 0.0439 & 0.0535 & 0.0326 & 1080 & 534 \\
\hline 15 & 62 & 270137 & 358629 & 0.9995 & 181.1 & 9924.4 & 0.0455 & 0.0553 & 0.036 & 1129 & 577 \\
\hline 16 & 65 & 264937 & 350119 & 0.9995 & 202.1 & 9806.6 & 0.0475 & 0.0573 & 0.0432 & 1195 & 642 \\
\hline 17 & 62 & 261287 & 343416 & 0.9994 & 221.7 & 9700.2 & 0.0496 & 0.0597 & 0.049 & 1260 & 704 \\
\hline 18 & 61 & 254975 & 335304 & 0.9993 & 239.4 & 9521.7 & 0.0512 & 0.0615 & 0.0561 & 1313 & 758 \\
\hline 19 & 64 & 251290 & 328154 & 0.9993 & 255.1 & 9420 & 0.0532 & 0.0635 & 0.0624 & 1361 & 805 \\
\hline 20 & 66 & 248169 & 322622 & 0.9993 & 270.6 & 9350 & 0.055 & 0.0655 & 0.0674 & 1414 & 854 \\
\hline 21 & 64 & 239876 & 312117 & 0.9991 & 294.2 & 9092.9 & 0.057 & 0.0672 & 0.077 & 1473 & 925 \\
\hline 22 & 63 & 231153 & 296624 & 0.9988 & 313.5 & 8786.8 & 0.0591 & 0.0695 & 0.0916 & 1520 & 975 \\
\hline 23 & 63 & 224515 & 287561 & 0.9989 & 324.7 & 8603.3 & 0.061 & 0.0713 & 0.1003 & 1549 & 1003 \\
\hline 24 & 65 & 219473 & 281136 & 0.9992 & 337.7 & 8432.1 & 0.0628 & 0.0734 & 0.1067 & 1584 & 1041 \\
\hline
\end{tabular}




\begin{tabular}{|c|c|c|c|c|c|c|c|c|c|c|c|}
\hline Specimen & & FYO-151 & & & & & & & & & \\
\hline $\begin{array}{c}\text { Unload } \\
\text { No. }\end{array}$ & $\begin{array}{c}\text { No. } \\
\text { Data } \\
\text { Points } \\
\end{array}$ & $\begin{array}{c}\text { Loadline } \\
\text { Slope } \\
\text { (Ib/in) } \\
\end{array}$ & $\begin{array}{l}\text { COD } \\
\text { Slope } \\
\text { (lb/in) } \\
\end{array}$ & Corr. & $\begin{array}{c}\text { Plastic } \\
\text { Area } \\
\text { (in-lb) }\end{array}$ & $\begin{array}{l}\text { Load } \\
\text { (lb.) }\end{array}$ & $\begin{array}{l}\text { Loadline } \\
\text { (in.) }\end{array}$ & $\begin{array}{l}\text { COD } \\
\text { (in.) } \\
\end{array}$ & $\begin{array}{l}\text { Delta } \\
\text { a } \\
\text { (in.) }\end{array}$ & $\begin{array}{c}J \\
\left(\mathrm{in}-\mathrm{Ib} / \mathrm{in}^{2}\right)\end{array}$ & $\begin{array}{c}J \\
\text { Plastic } \\
\left(\text { in-lb/in }{ }^{2}\right) \\
\end{array}$ \\
\hline 1 & 44 & 286300 & 395188 & 0.9997 & 0 & 4416.6 & 0.0109 & 0.0144 & -0.0002 & 100 & 0 \\
\hline 2 & 65 & 295888 & 391920 & 0.9997 & 3.2 & 6863.9 & 0.0185 & 0.0237 & 0.0023 & 252 & 10 \\
\hline 3 & 68 & 295699 & 390155 & 0.9998 & 14.1 & 7538.7 & 0.0212 & 0.0269 & 0.0037 & 338 & 46 \\
\hline 4 & 72 & 296954 & 388932 & 0.9998 & 24.2 & 8166.6 & 0.0241 & 0.0301 & 0.0047 & 418 & 78 \\
\hline 5 & 76 & 292840 & 385286 & 0.9997 & 41.1 & 8660 & 0.0271 & 0.0337 & 0.0076 & 520 & 133 \\
\hline 6 & 73 & 290727 & 383195 & 0.9997 & 46.9 & 8915.1 & 0.0288 & 0.0358 & 0.0092 & 567 & 152 \\
\hline 7 & 75 & 288122 & 381211 & 0.9997 & 57.6 & 9157 & 0.0308 & 0.038 & 0.0108 & 626 & 187 \\
\hline 8 & 75 & 286140 & 378635 & 0.9997 & 70.7 & 9345.6 & 0.0329 & 0.0404 & 0.0129 & 690 & 229 \\
\hline 9 & 75 & 282334 & 373122 & 0.9997 & 88.8 & 9492.4 & 0.0352 & 0.0431 & 0.0174 & 773 & 288 \\
\hline 10 & 71 & 278756 & 369776 & 0.9997 & 102.7 & 9600.6 & 0.0372 & 0.0455 & 0.0201 & 834 & 333 \\
\hline 11 & 70 & 276200 & 364734 & 0.9996 & 119.9 & 9665.4 & 0.0394 & 0.0478 & 0.0243 & 903 & 388 \\
\hline 12 & 67 & 273382 & 361850 & 0.9996 & 135.5 & 9687.7 & 0.0412 & 0.0499 & 0.0267 & 963 & 439 \\
\hline 13 & 68 & 270252 & 357461 & 0.9996 & 149.2 & 9689.8 & 0.0428 & 0.0516 & 0.0303 & 1013 & 483 \\
\hline 14 & 69 & 269147 & 354060 & 0.9996 & 162.1 & 9685.1 & 0.0444 & 0.0532 & 0.0332 & 1056 & 525 \\
\hline 15 & 71 & 264757 & 349172 & 0.9996 & 181.3 & 9703.5 & 0.0463 & 0.0554 & 0.0374 & 1129 & 587 \\
\hline 16 & 71 & 259551 & 341453 & 0.9995 & 205.7 & 9579.9 & 0.0487 & 0.058 & 0.044 & 1209 & 664 \\
\hline 17 & 74 & 256707 & 335206 & 0.9995 & 220.4 & 9498.3 & 0.0505 & 0.06 & 0.0495 & 1258 & 710 \\
\hline 18 & 75 & 253093 & 331126 & 0.9995 & 238.2 & 9438.1 & 0.0524 & 0.0623 & 0.0531 & 1322 & 768 \\
\hline 19 & 73 & 247297 & 322581 & 0.9995 & 258.1 & 9307 & 0.0543 & 0.0643 & 0.0607 & 1383 & 829 \\
\hline 20 & 71 & 240608 & 313427 & 0.9994 & 275.2 & 9047.1 & 0.056 & 0.0658 & 0.0691 & 1419 & 879 \\
\hline 21 & 72 & 234196 & 303133 & 0.9993 & 293.3 & 8902.2 & 0.0583 & 0.0684 & 0.0787 & 1479 & 931 \\
\hline 22 & 75 & 228781 & 294561 & 0.9993 & 310.5 & 8752.2 & 0.0604 & 0.0705 & 0.0869 & 1528 & 982 \\
\hline 23 & 73 & 224827 & 289436 & 0.9993 & 324.9 & 8639.5 & 0.0623 & 0.0728 & 0.0918 & 1575 & 1028 \\
\hline 24 & 76 & 219955 & 281934 & 0.9992 & 345.6 & 8519.8 & 0.0647 & 0.075 & 0.0992 & 1638 & 1093 \\
\hline 25 & 76 & 215986 & 274735 & 0.9992 & 364.5 & 8406.3 & 0.0671 & 0.0778 & 0.1064 & 1701 & 1151 \\
\hline
\end{tabular}




\begin{tabular}{|c|c|c|c|c|c|c|c|c|c|c|c|}
\hline Specimen & & FYO- 158 & & & & & & & & & \\
\hline $\begin{array}{c}\text { Unload } \\
\text { No. }\end{array}$ & $\begin{array}{c}\text { No. } \\
\text { Data } \\
\text { Points } \\
\end{array}$ & $\begin{array}{c}\text { Loadline } \\
\text { Slope } \\
\text { (lb/in) }\end{array}$ & $\begin{array}{l}\text { COD } \\
\text { Slope } \\
\text { (llb/in) } \\
\end{array}$ & Corr. & $\begin{array}{c}\text { Plastic } \\
\text { Area } \\
(\text { in-lb) }\end{array}$ & $\begin{array}{l}\text { Load } \\
\text { (lb.) }\end{array}$ & $\begin{array}{l}\text { Loadline } \\
\text { (iin.) } \\
\end{array}$ & $\begin{array}{l}\text { COD } \\
\text { (in.) }\end{array}$ & $\begin{array}{c}\text { Delta } \\
\text { a } \\
\text { (in.) }\end{array}$ & $\begin{array}{c}J \\
\left(\mathrm{in}-\mathrm{lb} / \mathrm{in}^{2}\right) \\
\end{array}$ & $\begin{array}{c}J \\
\text { Plastic } \\
\left(\mathrm{in}-\mathrm{lb} / \mathrm{in}^{2}\right)\end{array}$ \\
\hline 1 & 94 & 160034 & 207768 & 0.9999 & 0 & 2258.8 & 0.0105 & 0.0136 & 0 & 96 & 0 \\
\hline 2 & 77 & 160201 & 207548 & 0.9998 & 2 & 3223.8 & 0.016 & 0.0206 & 0.0003 & 211 & 12 \\
\hline 3 & 80 & 159322 & 207568 & 0.9998 & 6.2 & 3734.4 & 0.0196 & 0.0249 & 0.0003 & 303 & 39 \\
\hline 4 & 78 & 159398 & 207214 & 0.9998 & 8.6 & 3947.4 & 0.0214 & 0.0271 & 0.0008 & 350 & 54 \\
\hline 5 & 87 & 158990 & 206548 & 0.9998 & 12.8 & 4136.4 & 0.0233 & 0.0293 & 0.0018 & 407 & 81 \\
\hline 6 & 87 & 157716 & 206251 & 0.9998 & 17.1 & 4288.6 & 0.025 & 0.0314 & 0.0023 & 458 & 108 \\
\hline 7 & 86 & 157226 & 205760 & 0.9998 & 21.5 & 4423.4 & 0.0267 & 0.0333 & 0.003 & 507 & 136 \\
\hline 8 & 90 & 156686 & 204801 & 0.9998 & 26.9 & 4537 & 0.0284 & 0.0354 & 0.0045 & 564 & 170 \\
\hline 9 & 95 & 156200 & 203566 & 0.9997 & 33.4 & 4649.7 & 0.0304 & 0.0377 & 0.0064 & 628 & 211 \\
\hline 10 & 98 & 155509 & 202417 & 0.9997 & 39.9 & 4729.1 & 0.0321 & 0.0396 & 0.0081 & 683 & 252 \\
\hline 11 & 95 & 154551 & 201477 & 0.9997 & 44.4 & 4756.6 & 0.0332 & 0.0409 & 0.0096 & 721 & 281 \\
\hline 12 & 94 & 153152 & 199906 & 0.9997 & 51.7 & 4804.1 & 0.035 & 0.0429 & 0.012 & 779 & 327 \\
\hline 13 & 92 & 151721 & 198826 & 0.9996 & 58 & 4837.6 & 0.0366 & 0.0446 & 0.0137 & 828 & 367 \\
\hline 14 & 88 & 151127 & 197759 & 0.9997 & 64.1 & 4852.5 & 0.0381 & 0.0463 & 0.0153 & 873 & 405 \\
\hline 15 & 81 & 149747 & 195614 & 0.9996 & 71.6 & 4847.3 & 0.0395 & 0.0479 & 0.0187 & 925 & 452 \\
\hline 16 & 73 & 147974 & 192903 & 0.9996 & 79.6 & 4840.8 & 0.0412 & 0.0499 & 0.023 & 982 & 502 \\
\hline 17 & 71 & 146327 & 191412 & 0.9996 & 87.4 & 4858 & 0.0431 & 0.052 & 0.0254 & 1039 & 552 \\
\hline 18 & 76 & 144242 & 188199 & 0.9995 & 97.4 & 4823.4 & 0.0451 & 0.0542 & 0.0306 & 1103 & 613 \\
\hline 19 & 76 & 141688 & 184455 & 0.9993 & 107.4 & 4739.4 & 0.0469 & 0.0562 & 0.0367 & 1160 & 674 \\
\hline 20 & 78 & 139271 & 181004 & 0.9994 & 115.9 & 4695.9 & 0.0488 & 0.0581 & 0.0424 & 1212 & 726 \\
\hline 21 & 79 & 137264 & 177688 & 0.9994 & 123.2 & 4634.7 & 0.0504 & 0.0599 & 0.0479 & 1257 & 769 \\
\hline 22 & 82 & 135716 & 175396 & 0.9995 & 132.7 & 4624.3 & 0.0526 & 0.0622 & 0.0518 & 1318 & 830 \\
\hline 23 & 77 & 132899 & 171480 & 0.9994 & 141.6 & 4524.6 & 0.0541 & 0.0639 & 0.0585 & 1365 & 882 \\
\hline 24 & 76 & 129897 & 166921 & 0.9993 & 148.6 & 4416.7 & 0.0556 & 0.0655 & 0.0665 & 1398 & 920 \\
\hline 25 & 76 & 127111 & 163183 & 0.9994 & 156.1 & 4351.4 & 0.0574 & 0.0673 & 0.0732 & 1439 & 964 \\
\hline 26 & 79 & 124987 & 159396 & 0.9993 & 161.4 & 4313.6 & 0.059 & 0.0689 & 0.08 & 1470 & 992 \\
\hline 27 & 80 & 123175 & 156872 & 0.9992 & 168.8 & 4245.6 & 0.0606 & 0.0708 & 0.0846 & 1514 & 1037 \\
\hline 28 & 82 & 122272 & 154879 & 0.9994 & 175.2 & 4228.8 & 0.0623 & 0.0726 & 0.0883 & 1555 & 1078 \\
\hline 29 & 84 & 120056 & 151590 & 0.9992 & 184.8 & 4161.9 & 0.0642 & 0.0746 & 0.0945 & 1613 & 1137 \\
\hline 30 & 87 & 119488 & 149955 & 0.9993 & 191.9 & 4134.9 & 0.0662 & 0.0767 & 0.0976 & 1660 & 1183 \\
\hline 31 & 92 & 117463 & 146042 & 0.9992 & 202.4 & 4059 & 0.0681 & 0.0786 & 0.1051 & 1717 & 1246 \\
\hline
\end{tabular}




\begin{tabular}{|c|c|c|c|c|c|c|c|c|c|c|c|}
\hline $\begin{array}{c}\text { Unload } \\
\text { No. }\end{array}$ & $\begin{array}{c}\text { No. } \\
\text { Data } \\
\text { Points } \\
\end{array}$ & $\begin{array}{c}\text { Loadline } \\
\text { Slope } \\
\text { (lb/in) }\end{array}$ & $\begin{array}{l}\text { COD } \\
\text { Slope } \\
(\mathrm{lb} / \mathrm{in}) \\
\end{array}$ & Corr. & $\begin{array}{c}\text { Plastic } \\
\text { Area } \\
(\text { in-lb) }\end{array}$ & Load & Loadline & COD & $\begin{array}{c}\text { Delta } \\
\text { a } \\
\text { (in.) }\end{array}$ & $\begin{array}{c}J \\
\left(\mathrm{in}-\mathrm{lb} / \mathrm{in}^{2}\right)\end{array}$ & $\begin{array}{c}\mathrm{J} \\
\text { Plastic } \\
\left(\mathrm{in}-\mathrm{b} / \mathrm{in}^{2}\right) \\
\end{array}$ \\
\hline 1 & 56 & 143763 & 192616 & 0.9996 & 0 & 2169.1 & 0.0111 & 0.0144 & -0.0017 & 99 & 0 \\
\hline 2 & 54 & 142988 & 193574 & 0.9996 & 0.7 & 2990.2 & 0.0162 & 0.0206 & -0.0032 & 189 & 5 \\
\hline 3 & 54 & 142204 & 192462 & 0.9996 & 2 & 3337.9 & 0.0188 & 0.0237 & -0.0014 & 245 & 13 \\
\hline 4 & 53 & 142373 & 192634 & 0.9996 & 4.2 & 3582.7 & 0.0209 & 0.0262 & -0.0017 & 296 & 28 \\
\hline 5 & 53 & 142199 & 192484 & 0.9997 & 8 & 3822.7 & 0.0233 & 0.029 & -0.0014 & 358 & 53 \\
\hline 6 & 52 & 141117 & 191887 & 0.9996 & 12.5 & 3993.3 & 0.0254 & 0.0313 & -0.0005 & 414 & 81 \\
\hline 7 & 51 & 141454 & 191185 & 0.9996 & 16.4 & 4145.3 & 0.0273 & 0.0336 & 0.0006 & 467 & 107 \\
\hline 8 & 51 & 140802 & 191338 & 0.9997 & 22.2 & 4248.5 & 0.0292 & 0.0357 & 0.0004 & 523 & 145 \\
\hline 9 & 51 & 141169 & 189944 & 0.9996 & 27.1 & 4348.1 & 0.0309 & 0.0376 & 0.0026 & 576 & 177 \\
\hline 10 & 51 & 140870 & 188859 & 0.9996 & 33.7 & 4425 & 0.0327 & 0.0396 & 0.0044 & 636 & 220 \\
\hline 11 & 51 & 141226 & 189245 & 0.9993 & 41 & 4502.2 & 0.0347 & 0.0418 & 0.0037 & 697 & 269 \\
\hline 12 & 51 & 139430 & 188540 & 0.9994 & 48.8 & 4545.8 & 0.0366 & 0.0439 & 0.0049 & 760 & 320 \\
\hline 13 & 51 & 139542 & 187304 & 0.9995 & $\cdot 55$ & 4607.4 & 0.0385 & 0.0459 & 0.0069 & 814 & 360 \\
\hline 14 & 51 & 138595 & 18524.5 & 0.9993 & 65.5 & 4647.1 & 0.0408 & 0.0485 & 0.0103 & 895 & 428 \\
\hline 15 & 51 & 137144 & 183753 & 0.9992 & 72.7 & 4660.8 & 0.0426 & 0.0504 & 0.0127 & 950 & 474 \\
\hline 16 & 51 & 137672 & 182645 & 0.9992 & 79.4 & 4674.3 & 0.0443 & 0.0523 & 0.0145 & 1000 & 518 \\
\hline 17 & 51 & 136384 & 182236 & 0.9991 & 87.2 & 4669.5 & 0.0458 & 0.0537 & 0.0152 & 1051 & 569 \\
\hline 18 & 53 & 134662 & 179966 & 0.9992 & 94.7 & 4636.9 & 0.0474 & 0.0555 & 0.019 & 1101 & 617 \\
\hline 19 & 53 & 134069 & 178271 & 0.9995 & 101.9 & 4603.4 & 0.0491 & 0.057 & 0.0218 & 1142 & 663 \\
\hline 20 & 53 & 132422 & 175503 & 0.9994 & 110.3 & 4589.3 & 0.0508 & 0.059 & 0.0265 & 1200 & 715 \\
\hline 21 & 53 & 130951 & 173294 & 0.9994 & 116.7 & 4552.6 & 0.0524 & 0.0605 & 0.0303 & 1242 & 755 \\
\hline 22 & 55 & 129753 & 172019 & 0.9995 & 124.1 & 4529.3 & 0.0541 & 0.0624 & 0.0325 & 1290 & 803 \\
\hline 23 & 55 & 129004 & 169833 & 0.9994 & 133 & 4483.7 & 0.056 & 0.0644 & 0.0363 & 1347 & 860 \\
\hline 24 & 55 & 127986 & 168522 & 0.9991 & 139.9 & 4495.7 & 0.0577 & 0.0661 & 0.0386 & 1395 & 905 \\
\hline 25 & 56 & 125961 & 165333 & 0.9991 & 149.8 & 4417.6 & 0.0596 & 0.0681 & 0.0442 & 1453 & 966 \\
\hline 26 & 56 & 124286 & 162687 & 0.9991 & 158 & 4358.9 & 0.0615 & 0.0699 & 0.0489 & 1497 & 1017 \\
\hline 27 & 55 & 122650 & 160199 & 0.999 & 166 & 4291.7 & 0.0632 & 0.0716 & 0.0534 & 1543 & 1066 \\
\hline 28 & 55 & 120013 & 156805 & 0.999 & 172.9 & 4252.6 & 0.065 & 0.0733 & 0.0596 & 1584 & 1106 \\
\hline 29 & 54 & 117471 & 153682 & 0.9989 & 178.6 & 4171.6 & 0.0664 & 0.0749 & 0.0654 & 1612 & 1137 \\
\hline 30 & 56 & 115677 & 150955 & 0.999 & 185.4 & 4136.6 & 0.0684 & 0.0769 & 0.0706 & 1652 & 1177 \\
\hline 31 & 58 & 113014 & 147002 & 0.9989 & 193.7 & 4050.8 & 0.0703 & 0.0787 & 0.0781 & 1694 & 1224 \\
\hline 32 & 57 & 110133 & 143418 & 0.999 & 199.3 & 3983 & 0.0719 & 0.0804 & 0.0851 & 1723 & 1253 \\
\hline 33 & 57 & 108943 & 141421 & 0.9992 & 203.5 & 3919.5 & 0.0733 & 0.0816 & 0.089 & 1739 & 1276 \\
\hline
\end{tabular}




\begin{tabular}{|c|c|c|c|c|c|c|c|c|c|c|c|}
\hline Specimen & & FYO-159 & & & & & & & & & \\
\hline $\begin{array}{l}\text { Unload } \\
\text { No. }\end{array}$ & $\begin{array}{c}\text { No. } \\
\text { Data } \\
\text { Points }\end{array}$ & $\begin{array}{l}\text { Loadline } \\
\text { Slope } \\
\text { (bb/in) }\end{array}$ & $\begin{array}{l}\text { COD } \\
\text { Slope } \\
(\text { lb/in) } \\
\end{array}$ & Corr. & $\begin{array}{c}\text { Plastic } \\
\text { Area } \\
(\text { in-lb) }\end{array}$ & $\begin{array}{l}\text { Load } \\
\text { (lb.) }\end{array}$ & $\begin{array}{l}\text { Loadline } \\
\text { (in.) } \\
\end{array}$ & $\begin{array}{l}\text { COD } \\
\text { (in.) } \\
\end{array}$ & $\begin{array}{c}\text { Delta } \\
\text { a } \\
\text { (in.) }\end{array}$ & $\begin{array}{c}J \\
\left(\mathrm{in}-\mathrm{lb} / \mathrm{in}^{2}\right) \\
\end{array}$ & $\begin{array}{c}\text { J } \\
\text { Plastic } \\
\left(\text { in-lb/in }{ }^{2}\right)\end{array}$ \\
\hline 34 & 60 & 107717 & 138685 & 0.999 & 211.9 & 3890.2 & 0.0755 & 0.0841 & 0.0945 & 1797 & 1329 \\
\hline 35 & 61 & 106268 & 136457 & 0.9989 & 218.8 & 3863 & 0.0774 & 0.0858 & 0.099 & 1839 & 1371 \\
\hline 36 & 63 & 104614 & 133395 & 0.9989 & 225.3 & 3802.1 & 0.079 & 0.0875 & 0.1052 & 1874 & 1407 \\
\hline
\end{tabular}




\begin{tabular}{|c|c|c|c|c|c|c|c|c|c|c|c|}
\hline Specimen & & FYO- 160 & & & & & & & & & \\
\hline $\begin{array}{l}\text { Unload } \\
\text { No. }\end{array}$ & $\begin{array}{c}\text { No. } \\
\text { Data } \\
\text { Points }\end{array}$ & $\begin{array}{l}\text { Loadline } \\
\text { Slope } \\
\text { (lb/in) }\end{array}$ & $\begin{array}{l}\text { COD } \\
\text { Slope } \\
\text { (b/in) }\end{array}$ & Corr. & $\begin{array}{l}\text { Plastic } \\
\text { Area } \\
(\text { in-lb) }\end{array}$ & $\begin{array}{l}\text { Load } \\
\text { (lb.) }\end{array}$ & $\begin{array}{l}\text { Loadline } \\
\text { (in.) }\end{array}$ & $\begin{array}{l}\text { COD } \\
\text { (in.) }\end{array}$ & $\begin{array}{l}\text { Delta } \\
\text { a } \\
\text { (in.) }\end{array}$ & $\begin{array}{c}J \\
\left(\mathrm{in}-\mathrm{lb} / \mathrm{in}^{2}\right)\end{array}$ & $\begin{array}{c}\mathbf{J} \\
\text { Plastic } \\
\left(\text { in-lb/in }{ }^{2}\right)\end{array}$ \\
\hline 1 & 92 & 708246.6 & 3733138.2 & 0.99942 & 0.6 & 7198.3 & 0.00183 & 0.00977 & 0.00071 & 54.2 & 1 \\
\hline 2 & 55 & 703380.5 & 3728577.5 & 0.99845 & 3.5 & 10454.3 & 0.00283 & 0.01451 & 0.00098 & 116.7 & 5.9 \\
\hline 3 & 56 & 707201.3 & 3713487.5 & 0.99886 & 11 & 14819.4 & 0.00451 & 0.02137 & 0.00185 & 240.5 & 18.4 \\
\hline 4 & 55 & 707706.3 & 3700816.5 & 0.99907 & 33.9 & 17621 & 0.00607 & 0.0266 & 0.00259 & 370.6 & 56.8 \\
\hline 5 & 71 & 713371.2 & 3654276.2 & 0.99923 & 62.7 & 19247.6 & 0.00741 & 0.03045 & 0.00536 & 481.2 & 106.1 \\
\hline 6 & 84 & 713881.8 & 3595747.7 & 0.9994 & 103 & 20521.3 & 0.00882 & 0.03402 & 0.00893 & 608.5 & 175.9 \\
\hline 7 & 89 & 711043.7 & 3556632.1 & 0.99939 & 141.4 & 21312.5 & 0.01006 & 0.03686 & 0.01137 & 719.4 & 243 \\
\hline 8 & 71 & 709746.3 & 3493864.5 & 0.99913 & 182.4 & 21878.7 & 0.01136 & 0.03967 & 0.01541 & 822.3 & 316.8 \\
\hline 9 & 78 & 704187.9 & 3430653.8 & 0.99915 & 225.7 & 22435.1 & 0.01267 & 0.04245 & 0.01962 & 931.6 & 395.9 \\
\hline 10 & 80 & 700753.4 & 3339309.4 & 0.99931 & 265.8 & 22839.5 & 0.01399 & 0.04513 & 0.02595 & 1041.7 & 473.6 \\
\hline 11 & 83 & 699631.9 & 3269552.4 & 0.99936 & 302.3 & 23113.1 & 0.01508 & 0.04706 & 0.03101 & 1140.3 & 544.9 \\
\hline 12 & 78 & 695774.2 & 3236614.4 & 0.99933 & 336 & 23288.8 & 0.01601 & 0.04885 & 0.03346 & 1211.7 & 608.9 \\
\hline 13 & 77 & 693018.1 & 3188252.1 & 0.99943 & 367 & 23448.4 & 0.01696 & 0.0506 & 0.03715 & 1297.2 & 670.3 \\
\hline 14 & 69 & 688339.1 & 3139332.8 & 0.99927 & 400.8 & 23420.7 & 0.01792 & 0.05211 & 0.04099 & 1370.4 & 738.1 \\
\hline 15 & 70 & 684017.1 & 3035732 & 0.99944 & 440.3 & 23446 & 0.01918 & 0.05408 & 0.04947 & 1475.1 & 826.2 \\
\hline 16 & 68 & 679616.9 & 2964077 & 0.99928 & 482.7 & 23523.6 & 0.02046 & 0.05623 & 0.05565 & 1582.5 & 917.8 \\
\hline 17 & 72 & 677817.5 & 2891162.4 & 0.99935 & 518.3 & 23503.6 & 0.021 .56 & 0.05784 & 0.0622 & 1676 & 999 \\
\hline 18 & 59 & 670387.8 & 2749831.1 & 0.99906 & 578.9 & 23154.4 & 0.02324 & 0.05996 & 0.07574 & 1834.6 & 1147.9 \\
\hline 19 & 57 & 662956.5 & 2658458.3 & 0.99915 & 604.2 & 23048 & 0.02427 & 0.06123 & 0.08512 & 1921.4 & 1220.1 \\
\hline 20 & 68 & 663222.1 & 2571594.1 & 0.99932 & 628.9 & 23001.4 & 0.02528 & 0.06268 & 0.09455 & 2011.1 & 1293.3 \\
\hline 21 & 69 & 659743.2 & 2480611.8 & 0.9991 & 666.5 & 22688.5 & 0.02628 & 0.06373 & 0.105 & 2122 & 1398.8 \\
\hline 22 & 76 & 652328.2 & 2368346.9 & 0.99913 & 696.2 & 22388 & 0.02734 & 0.06489 & 0.11875 & 2229.7 & 1499.5 \\
\hline 23 & 65 & 642731.3 & 2319000.5 & 0.99927 & 716.7 & 22236.7 & 0.02826 & 0.06595 & 0.12513 & 2296.9 & 1562.2 \\
\hline 24 & 63 & 637879.4 & 2231760.6 & 0.99935 & 747.4 & 22017.9 & 0.02956 & 0.06752 & 0.13691 & 2411.8 & 1665.4 \\
\hline 25 & 69 & 632216.8 & 2160709.3 & 0.99924 & 777.4 & 21844.5 & 0.03064 & 0.06878 & 0.14704 & 2521 & 1765.8 \\
\hline 26 & 75 & 629253.3 & 2076642.8 & 0.99916 & 811.7 & 21700.8 & 0.03196 & 0.07052 & 0.15967 & 2657.2 & 1888.2 \\
\hline 27 & 66 & 615587 & 2005531.6 & 0.99922 & 851.3 & 21391.8 & 0.03322 & 0.07192 & 0.17096 & 2795.6 & 2023.6 \\
\hline 28 & 66 & 610159.8 & 1923977.6 & م 19903 & 878.9 & 20978.4 & 0.034 .56 & 0.0733 & 0.18462 & 2916.6 & 2144.4 \\
\hline 29 & 71 & 603065.5 & 1857028.1 & 0.9991 & 912.8 & 20770.5 & 0.03583 & 0.07483 & 0.19646 & 3056 & 2278.9 \\
\hline
\end{tabular}




\begin{tabular}{|c|c|c|c|c|c|c|c|c|c|c|c|}
\hline Specimen & & FYO-161 & & & & & & & & & \\
\hline $\begin{array}{c}\text { Unload } \\
\text { No. }\end{array}$ & $\begin{array}{c}\text { No. } \\
\text { Data } \\
\text { Points } \\
\end{array}$ & $\begin{array}{c}\text { Loadline } \\
\text { Slope } \\
\text { (lb/in) }\end{array}$ & $\begin{array}{l}\text { COD } \\
\text { Slope } \\
(\mathrm{lb} / \mathrm{in}) \\
\end{array}$ & Corr. & $\begin{array}{c}\text { Plastic } \\
\text { Area } \\
(\text { in-lb) }\end{array}$ & $\begin{array}{l}\text { Load } \\
\text { (lb.) }\end{array}$ & $\begin{array}{c}\text { Loadline } \\
\text { (in.) }\end{array}$ & $\begin{array}{l}\text { COD } \\
\text { (in.) }\end{array}$ & $\begin{array}{c}\text { Delta } \\
\text { a } \\
\text { (in.) } \\
\end{array}$ & $\begin{array}{c}J \\
\left(i n-l b / i n^{2}\right)\end{array}$ & $\begin{array}{c}\text { J } \\
\text { Plastic } \\
\left(i n-l b / i^{2}\right)\end{array}$ \\
\hline 1 & 71 & 712201.5 & 3933531.9 & 0.99909 & 0.4 & 6771.8 & 0.00158 & 0.00904 & 0.00073 & 46.5 & 0.6 \\
\hline 2 & 67 & 707102.5 & 3919505.4 & 0.99893 & 5.8 & 11982 & 0.00314 & 0.01675 & 0.00146 & 153 & 9.4 \\
\hline 3 & 65 & 705386.2 & 3908991.6 & 0.99906 & 17.3 & 15566.2 & 0.0046 & 0.02276 & 0.00201 & 261.1 & 28.1 \\
\hline 4 & 64 & 704093.9 & 3883441.2 & 0.99916 & 45.6 & 18321.3 & 0.00626 & 0.02832 & 0.00337 & 399.7 & 74.5 \\
\hline 5 & 77 & 702833.5 & 3849570.3 & 0.99935 & 82.2 & 20046.7 & 0.00779 & 0.03261 & 0.0052 & 523.9 & 135 \\
\hline 6 & 78 & 704405 & 3823921.3 & 0.99939 & 113.7 & 21037.3 & 0.00897 & 0.03573 & 0.0066 & 614.9 & 187.4 \\
\hline 7 & 77 & 703687.4 & 3775795.4 & 0.9993 & 153.6 & 21658.3 & 0.01009 & 0.03831 & 0.00928 & 714.7 & 255.1 \\
\hline 8 & 74 & 701874.9 & 3733718.9 & 0.99933 & 192.6 & 22337 & 0.01127 & 0.04106 & 0.01168 & 812.5 & 321.9 \\
\hline 9 & 72 & 700123.5 & 3666672.2 & 0.99929 & 233.4 & 22757.2 & 0.01249 & 0.04362 & 0.01561 & 912.9 & 394.3 \\
\hline 10 & 75 & 693750.6 & 3598238.8 & 0.99926 & 284.8 & 23109.4 & 0.01382 & 0.0463 & 0.01977 & 1031.2 & 486.4 \\
\hline 11 & 76 & 690067.4 & 3496566.8 & 0.99926 & 328.9 & 23312.5 & 0.01518 & 0.04881 & 0.02623 & 1146 & 571 \\
\hline 12 & 74 & 685741 & 3408872.5 & 0.99942 & 361.7 & 23474.5 & 0.01621 & 0.05073 & 0.0321 & 1223.8 & 636.6 \\
\hline 13 & 71 & 683855.8 & 3353745.2 & 0.99936 & 394.2 & 23556.9 & 0.01714 & 0.05224 & 0.03593 & 1308.2 & 700 \\
\hline 14 & 72 & 681018.1 & 3265409 & 0.99932 & 431.1 & 23668.9 & 0.01821 & 0.05413 & 0.04231 & 1402.2 & 776.9 \\
\hline 15 & 67 & 675726.8 & 3166443.6 & 0.9993 & 467 & 23506.6 & 0.0192 & 0.05545 & 0.04985 & 1485 & 855.8 \\
\hline 16 & 71 & 669318.1 & 3033813.1 & 0.99923 & 506.4 & 23371.2 & 0.02047 & 0.05722 & 0.06064 & 1604.1 & 950.3 \\
\hline 17 & 76 & 666198.1 & 2960632.4 & 0.9993 & 534.6 & 23430.2 & 0.02152 & 0.05884 & 0.06695 & 1684.7 & 1016.5 \\
\hline 18 & 69 & 662358.7 & 2882689.3, & 0.99931 & 565.8 & 23371.9 & 0.02241 & 0.06021 & 0.07398 & 1774.1 & 1091.5 \\
\hline 19 & 69 & 657390.8 & 2840456 & 0.99936 & 590.2 & 23374.7 & 0.0232 & 0.06145 & 0.07792 & 1829.1 & 1147.7 \\
\hline 20 & 70 & 649758.4 & 2737474.7 & 0.9994 & 624 & 23227.6 & 0.02427 & 0.06295 & 0.08797 & 1934.4 & 1238.2 \\
\hline 21 & 73 & 652924 & 2704574.4 & 0.99942 & 632.7 & 23156.4 & 0.02478 & 0.06372 & 0.09132 & 1964.3 & 1263.6 \\
\hline 22 & 69 & 649082.9 & 2647260 & 0.99935 & 671.5 & 23058.2 & 0.02568 & 0.06505 & 0.09731 & 2060.7 & 1357.1 \\
\hline 23 & 75 & 641123.1 & 2552820.4 & 0.99939 & 706.8 & 22852.7 & 0.02682 & 0.06642 & 0.10766 & 2172.8 & 1457.5 \\
\hline 24 & 70 & 633651.8 & 2506153.7 & 0.99932 & 731.8 & 22763.7 & 0.02779 & 0.0677 & 0.11301 & 2246.4 & 1524.5 \\
\hline 25 & 73 & 633396.9 & 2453589.9 & 0.9993 & 752.9 & 22672.1 & 0.02867 & 0.06904 & 0.11922 & 2323.8 & 1587 \\
\hline 26 & 77 & 627060.8 & 2389561 & 0.9993 & 789.2 & 22579 & 0.02967 & 0.0705 & 0.12708 & 2426.2 & 1688.6 \\
\hline 27 & 74 & 623521.6 & 2332441.9 & 0.99931 & 815.8 & 22426.4 & 0.03062 & 0.07166 & 0.13437 & 2511.2 & 1769.6 \\
\hline 28 & 70 & 619148.6 & 2265397.3 & 0.99935 & 855.2 & 22207.8 & 0.03184 & 0.07324 & 0.14329 & 2637.1 & 1886.8 \\
\hline 29 & 67 & 614317.7 & 2209155.1 & 0.99935 & 882.5 & 22042.9 & 0.03283 & 0.07455 & 0.15108 & 2726.5 & 1975.7 \\
\hline 30 & 64 & 607549.6 & 2135032.4 & 0.99927 & 921.5 & 21749.6 & 0.0341 & 0.07608 & 0.16182 & 2863.5 & 2105.3 \\
\hline 31 & 70 & 601415.2 & 2074612.1 & 0.9995 & 949.9 & 21676 & 0.03523 & 0.07765 & 0.17099 & 2971.6 & 2207.9 \\
\hline 32 & 67 & 595803.1 & 2008664.6 & 0.99929 & 977.5 & 21294.1 & 0.03625 & 0.07873 & 0.18145 & 3080.3 & 2317.3 \\
\hline 33 & 61 & 588695 & 1950406.1 & 0.99934 & 998.5 & 21108.8 & 0.03708 & 0.07967 & 0.1911 & 3186.9 & 2410.8 \\
\hline
\end{tabular}




\begin{tabular}{|c|c|c|c|c|c|c|c|c|c|c|c|c|c|c|c|c|}
\hline $\begin{array}{c}\text { Unload } \\
\text { No. }\end{array}$ & $\begin{array}{c}\text { No. of } \\
\text { Data } \\
\text { Points }\end{array}$ & $\begin{array}{l}\text { COD } \\
\text { (in.) }\end{array}$ & $\begin{array}{l}\text { COD } \\
\text { Slope } \\
\text { (lb/in) }\end{array}$ & $\begin{array}{l}\text { COD } \\
\text { Corr. }\end{array}$ & $\begin{array}{c}\text { Loadline } \\
\text { Disp. } \\
\text { (in.) }\end{array}$ & $\begin{array}{c}\text { Loadline } \\
\text { Slope } \\
\text { (lb/in) }\end{array}$ & $\begin{array}{c}\text { Loadline } \\
\text { Corr. }\end{array}$ & $\begin{array}{l}\text { Load } \\
\text { (lb.) }\end{array}$ & $\begin{array}{l}\text { COD } \\
\text { Area } \\
(\text { in-lb) }\end{array}$ & $\begin{array}{c}\mathrm{LL} \\
\text { Area } \\
(\text { in }-\mathrm{lb})\end{array}$ & $\begin{array}{c}\text { Crack } \\
\text { Length } \\
\text { (iin.) }\end{array}$ & $\begin{array}{c}\text { Crack } \\
\text { Extension } \\
\text { (in.) }\end{array}$ & $\begin{array}{c}J \\
\left(\mathrm{in}-\mathrm{l} \mathrm{b} / \mathrm{in}^{2}\right)\end{array}$ & $\begin{array}{c}\mathrm{J} \\
\text { Plastic } \\
\left(\mathrm{in}-\mathrm{lb} / \mathrm{in}^{2}\right)\end{array}$ & $\begin{array}{l}\text { CTOD } \\
\text { (in.) }\end{array}$ & $\begin{array}{c}\text { CTOD } \\
\text { Plastic } \\
\text { (in.) }\end{array}$ \\
\hline 1 & 82 & 0.0053 & 5616064 & 1.0000 & 0.0029 & 8019924 & 0.9991 & 30430 & 2 & -3 & 1.0596 & -0.0006 & 100 & 0 & 0.0000 & 0.0000 \\
\hline 2 & 200 & 0.0081 & 5616085 & 1.0000 & 0.0048 & 8136351 & 0.9995 & 45890 & -2 & -7 & 1.0596 & -0.0006 & 219 & -9 & 0.0000 & 0.0000 \\
\hline 3 & 85 & 0.0109 & 5587539 & 1.0000 & 0.0065 & 8090098 & 0.9999 & 59385 & 21 & 4 & 1.0614 & 0.0012 & 398 & 14 & 0.0000 & 0.0000 \\
\hline 4 & 107 & 0.0126 & 5557910 & 1.0000 & 0.0074 & 8124071 & 0.9999 & 66411 & 47 & 10 & 1.0633 & 0.0031 & 509 & 25 & 0.0000 & 0.0000 \\
\hline 5 & 133 & 0.0144 & 5525846 & 1.0000 & 0.0085 & 8167988 & 0.9999 & 73127 & 86 & 26 & 1.0654 & 0.0052 & 650 & 60 & 0.0000 & 0.0000 \\
\hline 6 & 169 & 0.0162 & 5476552 & 1.0000 & 0.0093 & 8168976 & 1.0000 & 78591 & 137 & 49 & 1.0686 & 0.0084 & 795 & 106 & 0.0000 & 0.0000 \\
\hline 7 & 112 & 0.0179 & 5415084 & 1.0000 & 0.0103 & 8151694 & 1.0000 & 83470 & 193 & 73 & 1.0727 & 0.0125 & 943 & 156 & 0.0000 & 0.0000 \\
\hline 8 & 150 & 0.0194 & 5376731 & 1.0000 & 0.0108 & 8152035 & 1.0000 & 869.56 & 257 & 100 & 1.0753 & 0.0151 & 1074 & 213 & 0.0000 & 0.0000 \\
\hline 9 & 198 & 0.0211 & 5293345 & 0.9999 & 0.0116 & 8113760 & 1.0000 & 90476 & 337 & 133 & 1.0809 & 0.0207 & 1229 & 280 & 0.0000 & 0.0000 \\
\hline 10 & 67 & 0.0233 & 5240089 & 1.0000 & 0.0129 & 8099657 & 1.0000 & 94234 & 452 & 184 & 1.0845 & 0.0243 & 1426 & 385 & 0.0000 & 0.0000 \\
\hline 11 & 70 & 0.0256 & 5095065 & 0.9999 & 0.0136 & 8021584 & 1.0000 & 96306 & 619 & 261 & 1.0947 & 0.0345 & 1666 & 542 & 0.0000 & 0.0000 \\
\hline 12 & 112 & 0.0282 & 4970982 & 0.9999 & 0.0147 & 7923607 & 1.0000 & 98757 & 776 & 334 & 1.1036 & 0.0434 & 1908 & 692 & 0.0000 & 0.0000 \\
\hline 13 & 179 & 0.0300 & 4738143 & 0.9997 & 0.0155 & 7706599 & 0.9999 & 99765 & 884 & 378 & 1.1209 & 0.0607 & 2085 & 774 & 0.0000 & 0.0000 \\
\hline 14 & 153 & 0.0306 & 4820617 & 0.9999 & 0.0162 & 7833191 & 0.9999 & 99403 & 855 & 362 & 1.1147 & 0.0545 & 2019 & 743 & 0.0000 & 0.0000 \\
\hline 15 & 181 & 0.0319 & 4758198 & 0.9999 & 0.0166 & 7796316 & 1.0000 & 100134 & 1006 & 429 & 1.1194 & 0.0592 & 2200 & 885 & 0.0000 & 0.0000 \\
\hline 16 & 94 & 0.0337 & 4638729 & 0.9999 & 0.0173 & 7674749 & 0.9999 & 101062 & 1133 & 490 & 1.1285 & 0.0683 & 2385 & 1006 & 0.0000 & 0.0000 \\
\hline 17 & 95 & 0.0363 & 4468136 & 0.9998 & 0.0184 & 7515667 & 0.9999 & 101550 & 1331 & 577 & 1.1421 & 0.0819 & 2635 & 1181 & 0.0000 & 0.0000 \\
\hline 18 & 101 & 0.0380 & 4373510 & 0.9998 & 0.0193 & 7426796 & 0.9999 & 101247 & 1425 & 619 & 1.1498 & 0.0896 & 2745 & 1265 & 0.0000 & 0.0000 \\
\hline 19 & 101 & 0.0398 & 4301155 & 0.9998 & 0.0199 & 7364667 & 0.9999 & 101052 & 1564 & 680 & 1.1558 & 0.0956 & 2894 & 1391 & 0.0000 & 0.0000 \\
\hline 20 & 155 & 0.0434 & 3964939 & 0.9991 & 0.0209 & 7044305 & 0.9996 & 100374 & 1899 & 824 & 1.1851 & 0.1249 & 3291 & 1663 & 0.0000 & 0.0000 \\
\hline 21 & 103 & 0.0443 & 4083137 & 0.9999 & 0.0212 & 7184853 & 0.9999 & 98436 & 1848 & 818 & 1.1745 & 0.1143 & 3181 & 1667 & 0.0000 & 0.0000 \\
\hline 22 & 107 & 0.0456 & 3913218 & 0.9998 & 0.0223 & 7012878 & 0.9999 & 98501 & 2046 & 896 & 1.1898 & 0.1296 & 3408 & 1816 & 0.0000 & 0.0000 \\
\hline 23 & 107 & 0.0477 & 3800780 & 0.9997 & 0.0228 & 6914778 & 0.9998 & 97922 & 2158 & 947 & 1.2002 & 0.1401 & 3537 & 1911 & 0.0000 & 0.0000 \\
\hline 24 & 98 & 0.0499 & 3696868 & 0.9996 & 0.0236 & 6805105 & 0.9996 & 97059 & 2319 & 1022 & 1.2102 & 0.1500 & 3711 & 2062 & 0.0000 & 0.0000 \\
\hline 25 & 98 & 0.0524 & 3515297 & 0.9993 & 0.0243 & 6609103 & 0.9997 & 95589 & 2530 & 1115 & 1.2282 & 0.1680 & 3929 & 2235 & 0.0000 & 0.0000 \\
\hline 26 & 84 & 0.0560 & 3303412 & 0.9998 & 0.0254 & 6364645 & 0.9999 & 88823 & 2919 & 1289 & 1.2503 & 0.1901 & 4153 & 2583 & 0.0000 & 0.0000 \\
\hline 27 & 80 & 0.0594 & 3082933 & 0.9997 & 0.0268 & 6055154 & 0.9998 & 86846 & 3134 & 1393 & 1.2747 & 0.2145 & 4380 & 2757 & 0.0000 & 0.0000 \\
\hline
\end{tabular}




\begin{tabular}{|c|c|c|c|c|c|c|c|c|c|c|c|c|c|c|c|c|}
\hline $\begin{array}{c}\text { Unload } \\
\text { No. }\end{array}$ & $\begin{array}{c}\text { No. of } \\
\text { Data } \\
\text { Points }\end{array}$ & $\begin{array}{l}\text { COD } \\
\text { (iil.) }\end{array}$ & $\begin{array}{l}\text { COD } \\
\text { Slope } \\
\text { (lb/in) } \\
\end{array}$ & $\begin{array}{l}\text { COD } \\
\text { Corr. }\end{array}$ & $\begin{array}{c}\text { Loadline } \\
\text { Disp. } \\
\text { (in.) }\end{array}$ & $\begin{array}{c}\text { Loadline } \\
\text { Slope } \\
\text { (lb/in) }\end{array}$ & $\begin{array}{c}\text { Loadline } \\
\text { Corr. }\end{array}$ & $\begin{array}{l}\text { Load } \\
\text { (lb.) }\end{array}$ & $\begin{array}{c}\text { COD } \\
\text { Areal } \\
(\text { in-lb) }\end{array}$ & $\begin{array}{c}\text { LL } \\
\text { Area } \\
(\text { in }- \text { lb })\end{array}$ & $\begin{array}{c}\text { Crack } \\
\text { Length } \\
\text { (in.) }\end{array}$ & $\begin{array}{c}\text { Crack } \\
\text { Extension } \\
\text { (in.) }\end{array}$ & $\begin{array}{c}\mathrm{J} \\
\left(\mathrm{in}-\mathrm{lb} / \mathrm{in}^{2}\right)\end{array}$ & $\begin{array}{c}\mathrm{J} \\
\text { Plastic } \\
\left(\mathrm{in}-\mathrm{lb} / \mathrm{in}^{2}\right)\end{array}$ & $\begin{array}{c}\text { CIOD } \\
\text { (in.) }\end{array}$ & $\begin{array}{c}\text { C'TOD } \\
\text { Plastic } \\
\text { (in.) }\end{array}$ \\
\hline 1 & 69 & 0.0059 & 3556527 & 1.0000 & 0.0033 & 6124949 & 0.9999 & 22387 & 2 & -2 & 1.2240 & 0.0005 & 93 & 1 & 0.0000 & 0.0000 \\
\hline 2 & 70 & 0.0095 & 3573553 & 1.0000 & 0.0053 & 6173353 & 0.9999 & 34412 & 3 & -4 & 1.2223 & -0.0012 & 212 & -3 & 0.0000 & 0.0000 \\
\hline 3 & 101 & 0.0129 & 3582663 & 1.0000 & 0.0071 & 6193687 & 1.0000 & 44686 & 26 & 4 & 1.2214 & -0.0021 & 377 & 15 & 0.0000 & 0.0000 \\
\hline 4 & 108 & 0.0165 & 3577314 & 1.0000 & 0.0089 & 6254355 & 1.0000 & 53982 & 77 & 23 & 1.2219 & -0.0016 & 587 & 58 & 0.0000 & 0.0000 \\
\hline 5 & 136 & 0.0191 & 3554404 & 1.0000 & 0.0102 & 6248385 & 1.0000 & 59642 & 134 & 50 & 1.2242 & 0.0007 & 772 & 121 & 0.0000 & 0.0000 \\
\hline 6 & 180 & 0.0213 & 3518105 & 1.0000 & 0.0111 & 6268865 & 1.0000 & 63691 & 197 & 75 & 1.2279 & 0.0044 & 930 & 178 & 0.0000 & 0.0000 \\
\hline 7 & 134 & 0.0234 & 3499517 & 1.0000 & 0.0121 & 6276275 & 1.0000 & 67204 & 252 & 106 & 1.2298 & 0.0063 & 1093 & 252 & 0.0000 & 0.0000 \\
\hline 8 & 153 & 0.0253 & 3457579 & 1.0000 & 0.0130 & 6238168 & 1.0000 & 70009 & 325 & 139 & 1.2341 & 0.0106 & 1253 & 327 & 0.0000 & 0.0000 \\
\hline 9 & 124 & 0.0273 & 3424606 & 1.0000 & 0.0141 & 6231073 & 1.0000 & 72483 & 399 & 172 & 1.2375 & 0.0140 & 1407 & 404 & 0.0000 & 0.0000 \\
\hline 10 & 142 & 0.0293 & 3385166 & 1.0000 & 0.0149 & 6207208 & 1.0000 & 74431 & 489 & 213 & 1.2416 & 0.0181 & 1571 & 499 & 0.0000 & 0.0000 \\
\hline 11 & 165 & 0.0313 & 3340204 & 1.0000 & 0.0155 & 6166284 & 1.0000 & 75995 & 583 & 255 & 1.2464 & 0.0229 & 1729 & 595 & 0.0000 & 0.0000 \\
\hline 12 & 95 & 0.0330 & 3308659 & 1.0000 & 0.0163 & 6142547 & 1.0000 & 77363 & 662 & 291 & 1.2497 & 0.0262 & 1868 & 679 & 0.0000 & 0.0000 \\
\hline 13 & 93 & 0.0355 & 3221129 & 1.0000 & 0.0173 & 6059114 & 1.0000 & 77799 & 831 & 362 & 1.2592 & 0.0357 & 2078 & 839 & 0.0000 & 0.0000 \\
\hline 14 & 130 & 0.0375 & 3158764 & 0.9999 & 0.0182 & 5985819 & 1.0000 & 78378 & 925 & 409 & 1.2662 & 0.0427 & 2231 & 945 & 0.0000 & 0.0000 \\
\hline 15 & 185 & 0.0392 & 3094926 & 0.9998 & 0.0189 & 5914497 & 1.0000 & 79014 & 1007 & 446 & 1.2734 & 0.0499 & 2364 & 1026 & 0.0000 & 0.0000 \\
\hline 16 & 172 & 0.0406 & 3082644 & 0.9999 & 0.0196 & 5898638 & 1.0000 & 79041 & 1074 & 481 & 1.2748 & 0.0513 & 2454 & 1109 & 0.0000 & 0.0000 \\
\hline 17 & 118 & 0.0423 & 3030951 & 0.9999 & 0.0201 & 5851293 & 1.0000 & 79394 & 1193 & 528 & 1.2807 & 0.0572 & 2599 & 1216 & 0.0000 & 0.0000 \\
\hline 18 & 99 & 0.0445 & 2950660 & 0.9998 & 0.0211 & 5810027 & 0.9999 & 79911 & 1316 & 585 & 1.2902 & 0.0667 & 2787 & 1343 & 0.0000 & 0.0000 \\
\hline 19 & 82 & 0.0459 & 2929489 & 0.9999 & 0.0217 & 5791555 & 0.9994 & 79464 & 1382 & 626 & 1.2927 & 0.0692 & 2880 & 1440 & 0.0000 & 0.0000 \\
\hline 20 & 81 & 0.0477 & 2858580 & 0.9999 & 0.0221 & 5645739 & 1.0000 & 77645 & 1558 & 693 & 1.3013 & 0.0778 & 3002 & 1588 & 0.0000 & 0.0000 \\
\hline 21 & 146 & 0.0494 & 2768588 & 0.9997 & 0.0231 & 5563459 & 0.9999 & 78336 & 1618 & 713 & 1.3125 & 0.0890 & 3111 & 1619 & 0.0000 & 0.0000 \\
\hline 22 & 156 & 0.0505 & 2719929 & 0.9998 & 0.0235 & 5511474 & 0.9999 & 77476 & 1660 & 740 & 1.3187 & 0.0952 & 3164 & 1675 & 0.0000 & 0.0000 \\
\hline 23 & 171 & 0.0522 & 2638091 & 0.9997 & 0.0238 & 5391929 & 0.9999 & 76086 & 1789 & 789 & 1.3293 & 0.1058 & 3265 & 1777 & 0.0000 & 0.0000 \\
\hline 24 & 168 & 0.0539 & 2540203 & 0.9994 & 0.0245 & 5284984 & 0.9999 & 74894 & 1885 & 825 & 1.3424 & 0.1189 & 3344 & 1839 & 0.0000 & 0.0000 \\
\hline 25 & 185 & 0.0552 & 2522549 & 0.9998 & 0.0249 & 5244165 & 0.9999 & 73985 & 1927 & 835 & 1.3448 & 0.1213 & 3341 & 1860 & 0.0000 & 0.0000 \\
\hline 26 & 100 & 0.0565 & 2450115 & 0.9997 & 0.0256 & 5289226 & 0.9989 & 73497 & 2022 & 861 & 1.3548 & 0.1313 & 3414 & 1903 & 0.0000 & 0.0000 \\
\hline
\end{tabular}




\begin{tabular}{|c|c|c|c|c|c|c|c|c|c|c|c|c|c|c|c|c|}
\hline $\begin{array}{c}\text { Unload } \\
\text { No. }\end{array}$ & $\begin{array}{l}\text { No. of } \\
\text { Data } \\
\text { Points }\end{array}$ & $\begin{array}{l}\text { COD } \\
\text { (in.) }\end{array}$ & $\begin{array}{l}\text { COD } \\
\text { Slope } \\
\text { (lb/in) }\end{array}$ & $\begin{array}{l}\text { COD } \\
\text { Corr. }\end{array}$ & $\begin{array}{c}\text { Loadline } \\
\text { Disp. } \\
\text { (in.) }\end{array}$ & $\begin{array}{c}\text { Loadline } \\
\text { Slope } \\
\text { (lb/in) }\end{array}$ & $\begin{array}{l}\text { Loadline } \\
\text { Corr. }\end{array}$ & $\begin{array}{c}\text { Load } \\
\text { (lb.) }\end{array}$ & $\begin{array}{c}\text { COD } \\
\text { Area } \\
(\text { in }-l b)\end{array}$ & $\begin{array}{c}\mathbf{L L} \\
\text { Area } \\
(\text { in }-\mathrm{lb})\end{array}$ & $\begin{array}{c}\text { Crack } \\
\text { Length } \\
\text { (in.) }\end{array}$ & $\begin{array}{c}\text { Crack } \\
\text { Extension } \\
\text { (in.) } \\
\end{array}$ & $\begin{array}{c}\mathrm{J} \\
\left(\mathrm{in}-\mathrm{lb} / \mathrm{in}^{2}\right)\end{array}$ & $\begin{array}{c}\mathrm{J} \\
\text { Plastic } \\
\left(\mathrm{in}-\mathrm{lb} / \mathrm{in}^{2}\right)\end{array}$ & $\begin{array}{c}\text { CTOD } \\
\text { (in.) } \\
\end{array}$ & $\begin{array}{l}\text { CIOD } \\
\text { Plastic } \\
\text { (in.) }\end{array}$ \\
\hline 1 & 61 & 0.0086 & 1054072 & 1.0000 & 0.0021 & 2372649 & 0.9998 & 10503 & 3 & -4 & 1.6269 & 0.0081 & 107 & 20 & 0.0000 & 0.0000 \\
\hline 2 & 89 & 0.0192 & 1081139 & 1.0000 & 0.0068 & 2327990 & 1.0000 & 20269 & 17 & 7 & 1.6193 & 0.0005 & 368 & 57 & 0.0000 & 0.0000 \\
\hline 3 & 84 & 0.0262 & 1090958 & 1.0000 & 0.0100 & 2338890 & 1.0000 & 25484 & 76 & 25 & 1.6166 & -0.0022 & 606 & 119 & 0.0000 & 0.0000 \\
\hline 4 & 103 & 0.0342 & 1081912 & 1.0000 & 0.0136 & 2336382 & 1.0000 & 29983 & 190 & 74 & 1.6191 & 0.0003 & 964 & 283 & 0.0000 & 0.0000 \\
\hline 5 & 127 & 0.0448 & 1026974 & 0.9998 & 0.0183 & 2260996 & 0.9998 & 33408 & 421 & 173 & 1.6347 & 0.0158 & 1513 & 608 & 0.0000 & 0.0000 \\
\hline 6 & 123 & 0.0530 & 950256 & 0.9997 & 0.0217 & 2123435 & 0.9997 & 33807 & 629 & 266 & 1.6576 & 0.0387 & 1929 & 901 & 0.0000 & 0.0000 \\
\hline 7 & 77 & 0.0572 & 936854 & 0.9998 & 0.0232 & 2100992 & 0.9998 & 33784 & 685 & 290 & 1.6617 & 0.0429 & 2026 & 981 & 0.0000 & 0.0000 \\
\hline 8 & 69 & 0.0627 & 872685 & 0.9995 & 0.0253 & 1984408 & 0.9996 & 33144 & 872 & 367 & 1.6823 & 0.0634 & 2323 & 1216 & 0.0000 & 0.0000 \\
\hline 9 & 75 & 0.0687 & 817443 & 0.9996 & 0.0275 & 1884248 & 0.9996 & 31624 & 1040 & 437 & 1.7009 & 0.0821 & 2529 & 1429 & 0.0000 & 0.0000 \\
\hline 10 & 77 & 0.0739 & 783706 & 0.9997 & 0.0295 & 1822518 & 0.9997 & 30883 & 1155 & 486 & 1.7128 & 0.0940 & 2690 & 1579 & 0.0000 & 0.0000 \\
\hline 11 & 88 & 0.0830 & 699988 & 0.9996 & 0.0330 & 1652422 & 0.9995 & 28716 & 1461 & 606 & 1.7441 & 0.1253 & 3057 & 1937 & 0.0000 & 0.0000 \\
\hline 12 & 80 & 0.0922 & 614083 & 0.9997 & 0.0363 & 1466157 & 0.9995 & 25625 & 1707 & 700 & 1.7794 & 0.1606 & 3233 & 2166 & 0.0000 & 0.0000 \\
\hline
\end{tabular}




\begin{tabular}{|c|c|c|c|c|c|c|c|c|c|c|c|c|c|c|c|c|c|}
\hline & $\begin{array}{l}\text { Unload } \\
\text { No. }\end{array}$ & $\begin{array}{c}\text { No. of } \\
\text { Data } \\
\text { Points }\end{array}$ & $\begin{array}{l}\text { COD } \\
\text { (in.) }\end{array}$ & $\begin{array}{l}\text { COD } \\
\text { Slope } \\
\text { (lb/in) } \\
\end{array}$ & $\begin{array}{l}\text { COD } \\
\text { Corr. }\end{array}$ & $\begin{array}{c}\text { Loadline } \\
\text { Disp. } \\
\text { (in.) }\end{array}$ & $\begin{array}{c}\text { Loadline } \\
\text { Slope } \\
\text { (lb/in) }\end{array}$ & $\begin{array}{c}\text { Loadline } \\
\text { Corr. }\end{array}$ & $\begin{array}{l}\text { Load } \\
\text { (lb.) }\end{array}$ & $\begin{array}{c}\text { COD } \\
\text { Area } \\
\text { (in-lb) }\end{array}$ & $\begin{array}{c}\text { LL } \\
\text { Area } \\
(\text { in-lb) }\end{array}$ & $\begin{array}{c}\text { Crack } \\
\text { Length } \\
\text { (in.) } \\
\end{array}$ & $\begin{array}{c}\text { Crack } \\
\text { Extension } \\
\text { (in.) } \\
\end{array}$ & $\begin{array}{c}J \\
\left(\text { in-lb/in }{ }^{2}\right) \\
\end{array}$ & $\begin{array}{c}J \\
\text { Plastic } \\
(\text { in-lb/i112) }\end{array}$ & $\begin{array}{c}\text { CTOD } \\
\text { (in.) } \\
\end{array}$ & $\begin{array}{c}\text { CTOD } \\
\text { Plastic } \\
\text { (in.) } \\
\end{array}$ \\
\hline \multirow{27}{*}{$\infty$} & 1 & 95 & 0.0033 & 8167687 & 0.9999 & 0.0022 & 10099430 & 0.9995 & 29986 & 1 & -1 & 0.9267 & 0.0005 & 62 & -1 & 0.0000 & 0.0000 \\
\hline & 2 & 146 & 0.0059 & 8218552 & 1.0000 & 0.0044 & 10153550 & 0.9999 & 50191 & -0 & 1 & 0.9245 & -0.0017 & 177 & 1 & 0.0000 & 0.0000 \\
\hline & 3 & 107 & 0.0087 & 8171849 & 1.0000 & 0.0065 & 10301710 & 1.0000 & 70470 & 25 & 11 & 0.9265 & 0.0003 & 368 & 19 & 0.0000 & 0.0000 \\
\hline & 4 & 87 & 0.0122 & 8110693 & 1.0000 & 0.0088 & 10360230 & 1.0000 & 90673 & 104 & 52 & 0.9291 & 0.0029 & 671 & 88 & 0.0000 & 0.0000 \\
\hline & 5 & 105 & 0.0145 & 8023986 & 1.0000 & 0.0101 & 10432370 & 1.0000 & 100674 & 197 & 98 & 0.9328 & 0.0066 & 895 & 166 & 0.0000 & 0.0000 \\
\hline & 6 & 118 & 0.0161 & 7960724 & 1.0000 & 0.0109 & 10397600 & 1.0000 & 106650 & 279 & 142 & 0.9356 & 0.0094 & 1066 & 242 & 0.0000 & 0.0000 \\
\hline & 7 & 94 & 0.0174 & 7886380 & 1.0000 & 0.0118 & 10377490 & 1.0000 & 110690 & 352 & 176 & 0.9389 & 0.0127 & 1198 & 300 & 0.0000 & 0.0000 \\
\hline & 8 & 90 & 0.0184 & 7812250 & 1.0000 & 0.0120 & 10394250 & 1.0000 & 112818 & 416 & 206 & 0.9422 & 0.0160 & 1296 & 353 & 0.0000 & 0.0000 \\
\hline & 9 & 97 & 0.0195 & 7750983 & 1.0000 & 0.0128 & 10387670 & 1.0000 & 115417 & 487 & 245 & 0.9449 & 0.0187 & 1416 & 420 & 0.0000 & 0.0000 \\
\hline & 10 & 83 & 0.0207 & 7619816 & 1.0000 & 0.0134 & 10380140 & 1.0000 & 117636 & 589 & 293 & 0.9509 & 0.0247 & 1559 & 505 & 0.0000 & 0.0000 \\
\hline & 11 & 53 & 0.0220 & 7566131 & 1.0000 & 0.0140 & 10348160 & 1.0000 & 119560 & 675 & 341 & 0.9534 & 0.0272 & 1688 & 590 & 0.0000 & 0.0000 \\
\hline & 12 & 37 & 0.0226 & 7494444 & 1.0000 & 0.0144 & 10310300 & 1.0000 & 120179 & 728 & 365 & 0.9567 & 0.0305 & 1756 & 634 & 0.0000 & 0.0000 \\
\hline & 13 & 39 & 0.0228 & 7487886 & 1.0000 & 0.0147 & 10319910 & 1.0000 & 120592 & 728 & 368 & 0.9570 & 0.0308 & 1768 & 638 & 0.0000 & 0.0000 \\
\hline & 14 & 61 & 0.0236 & 7401214 & 1.0000 & 0.0142 & 11110930 & 1.0000 & 120936 & 817 & 392 & 0.9611 & 0.0349 & 1833 & 681 & 0.0000 & 0.0000 \\
\hline & 15 & 72 & 0.0252 & 7238051 & 0.9999 & 0.0151 & 10998130 & 0.9999 & 125054 & 921 & 557 & 0.9690 & 0.0428 & 2246 & 983 & 0.0000 & 0.0000 \\
\hline & 16 & 84 & 0.0269 & 7094342 & 0.9998 & 0.0159 & 10882520 & 0.9999 & 126663 & 1064 & 626 & 0.9760 & 0.0498 & 2437 & 1111 & 0.0000 & 0.0000 \\
\hline & 17 & 96 & 0.0291 & 6866687 & 0.9998 & 0.0167 & 10694610 & 0.9999 & 127209 & 1280 & 714 & 0.9876 & 0.0614 & 2665 & 1276 & 0.0000 & 0.0000 \\
\hline & 18 & 99 & 0.0307 & 6728332 & 0.9998 & 0.0174 & 10624000 & 0.9999 & 127914 & 1403 & 776 & 0.9948 & 0.0686 & 2833 & 1395 & 0.0000 & 0.0000 \\
\hline & 19 & 92 & 0.0323 & 6619400 & 0.9998 & 0.0179 & 10519890 & 0.9998 & 127511 & 1562 & 848 & 1.0006 & 0.0744 & 2990 & 1534 & 0.0000 & 0.0000 \\
\hline & 20 & 107 & 0.0340 & 6448162 & 0.9999 & 0.0184 & 10449290 & 0.9999 & 126198 & 1763 & 923 & 1.0100 & 0.0838 & 3151 & 1681 & 0.0000 & 0.0000 \\
\hline & 21 & 86 & 0.0358 & 6251293 & 0.9998 & 0.0193 & 10287270 & 0.9999 & 127217 & 1917 & 1004 & 1.0211 & 0.0949 & 3390 & 1841 & 0.0000 & 0.0000 \\
\hline & 22 & 100 & 0.0379 & 5933263 & 0.9995 & 0.0205 & 10073510 & 0.9998 & 127341 & 2096 & 1099 & 1.0398 & 0.1136 & 3683 & 2035 & 0.0000 & 0.0000 \\
\hline & 23 & 96 & 0.0388 & 5891925 & 0.9998 & 0.0210 & 10081300 & 0.9998 & 125272 & 2121 & 1117 & 1.0423 & 0.1161 & 3679 & 2072 & 0.0000 & 0.0000 \\
\hline & 24 & 97 & 0.0398 & 5842120 & 0.9999 & 0.0207 & 10045260 & 0.9998 & 124543 & 2239 & 1164 & 1.0454 & 0.1192 & 3767 & 2162 & 0.0000 & 0.0000 \\
\hline & 25 & 73 & 0.0415 & 5569795 & 0.9999 & 0.0220 & 9842932 & 0.9998 & 125087 & 2422 & 1263 & 1.0625 & 0.1363 & 4038 & 2327 & 0.0000 & 0.0000 \\
\hline & 26 & 67 & 0.0431 & 5596685 & 0.9999 & 0.0221 & 9801679 & 0.9996 & 123457 & 2518 & 1308 & 1.0608 & 0.1346 & 4083 & 2426 & 0.0000 & 0.0000 \\
\hline & 27 & 45 & 0.0449 & $\mathbf{5 3 3 4 8 7 8}$ & 0.9997 & 0.0227 & 9566421 & 0.9996 & 123711 & 2753 & 1396 & 1.0781 & 0.1519 & 4324 & 2566 & 0.0000 & 0.0000 \\
\hline
\end{tabular}




\begin{tabular}{|c|c|c|c|c|c|c|c|c|c|c|c|}
\hline ecimen & & B B & & & & & & & & & \\
\hline $\begin{array}{c}\text { Unload } \\
\text { No. }\end{array}$ & $\begin{array}{c}\text { No. } \\
\text { Data } \\
\text { Points }\end{array}$ & $\begin{array}{c}\text { Loadline } \\
\text { Slope } \\
\text { (lb/in) }\end{array}$ & $\begin{array}{l}\text { COD } \\
\text { Slope } \\
\text { (lb/in) }\end{array}$ & Corr. & $\begin{array}{l}\text { Plastic } \\
\text { Area } \\
\text { (in-lb) }\end{array}$ & $\begin{array}{l}\text { Load } \\
\text { (b.) }\end{array}$ & $\begin{array}{l}\text { Loadline } \\
\text { (in.) }\end{array}$ & $\begin{array}{l}\text { COD } \\
\text { (in.) }\end{array}$ & $\begin{array}{c}\text { Delta } \\
\text { a } \\
\text { (in.) }\end{array}$ & $\begin{array}{c}J \\
\left(\mathrm{in}-\mathrm{lb} / \mathrm{in}^{2}\right)\end{array}$ & $\begin{array}{c}\text { J } \\
\text { Plastic } \\
\left(\text { in-lb/in }{ }^{2}\right)\end{array}$ \\
\hline 5 & 47 & 11136938.4 & 16135552.9 & 0.99996 & 37.4 & 94120.6 & 0.00667 & 0.00961 & -0.00312 & 233.4 & 26 \\
\hline 6 & 93 & 11025869.4 & 16070599.5 & 0.99998 & 41.5 & 99304.8 & 0.00712 & 0.01012 & 0.00196 & 262.5 & 28.8 \\
\hline 7 & 58 & 11189833.8 & 16084360.8 & 0.99994 & 40.2 & 105495.6 & 0.00772 & 0.01075 & 0.00058 & 290.8 & 27.9 \\
\hline 8 & 42 & 11108950.7 & 16025578.9 & 0.99992 & 71.2 & 111151.8 & 0.00837 & 0.01142 & -0.00078 & 340.2 & 49.2 \\
\hline 9 & 56 & 11010743.4 & 15919502.3 & 0.99995 & 85.3 & 115181.8 & 0.00896 & 0.01197 & 0.00522 & 376 & 59 \\
\hline 10 & 55 & 10977309.9 & 15869206.4 & 0.99996 & 101.5 & 118525.4 & 0.00953 & 0.01251 & 0.00312 & 404.2 & 70.2 \\
\hline 11 & 61 & 10926467.8 & 15797248.7 & 0.99993 & 162.1 & 122899 & 0.01055 & 0.01344 & 0.00794 & 476 & 112.7 \\
\hline 12 & 31 & 10889315.7 & 15688359.2 & 0.99996 & 229.2 & 125732.8 & 0.01149 & 0.01429 & 0.00773 & 539.7 & 159.6 \\
\hline 13 & 50 & 10778931 & 15529039.7 & 0.99984 & 324.6 & 128131 & 0.0126 & 0.0153 & 0.01432 & 628.4 & 227.3 \\
\hline 14 & 49 & 10672189.2 & 15364624.4 & 0.99984 & 415.5 & 129827.6 & 0.01387 & 0.0162 & 0.02055 & 710.9 & 292.6 \\
\hline 15 & 58 & 10608222.2 & 15228652 & 0.99986 & 527.5 & 130666.8 & 0.01506 & 0.01722 & 0.02244 & 799.2 & 373.5 \\
\hline 16 & 72 & 10475059.6 & 15047091.1 & 0.99979 & 661.5 & 131413.4 & 0.01642 & 0.01839 & 0.03216 & 913.5 & 472.3 \\
\hline 17 & 73 & 10448053.9 & 15109717.9 & 0.99988 & 759.8 & 131351.2 & 0.01755 & 0.01921 & 0.03618 & 990.7 & 545.4 \\
\hline 18 & 54 & 10328401.8 & 14902505.5 & 0.99977 & 933.9 & 132176.8 & 0.01901 & 0.02083 & 0.04724 & 1141.9 & 678.1 \\
\hline 19 & 65 & 10258880 & 14753652.6 & 0.99971 & 1023.9 & 131901.8 & 0.01998 & 0.02164 & 0.05311 & 1216.6 & 747.6 \\
\hline 20 & 50 & 10187916.1 & 14632325.2 & 0.99971 & 1141 & 132126.2 & 0.02108 & 0.02264 & 0.05627 & 1313.2 & 838.7 \\
\hline 21 & 69 & 10149913.3 & 14595619.7 & 0.99978 & 1232.9 & 131400.8 & 0.02198 & 0.02335 & 0.06036 & 1385.3 & 910.9 \\
\hline 22 & 48 & 10069604.7 & 14542387.3 & 0.99976 & 1325.6 & 131724 & 0.02291 & 0.02415 & 0.06627 & 1469 & 984.8 \\
\hline 23 & 68 & 10048852.2 & 14272331.5 & 0.99978 & 1429.4 & 131075.8 & 0.02383 & 0.02497 & 0.0692 & 1551.3 & 1068.1 \\
\hline 24 & 40 & 10012989.5 & 14144781 & 0.99965 & 1558.4 & 131198.8 & 0.02494 & 0.026 & 0.07345 & 1662.2 & 1172.5 \\
\hline 25 & 42 & 9832728.4 & 13936210.5 & 0.99982 & 1758.4 & 130547.4 & 0.0265 & 0.02687 & 0.08006 & 1830.8 & 1337.2 \\
\hline
\end{tabular}




\begin{tabular}{|c|c|c|c|c|c|c|c|c|c|c|c|}
\hline Specimen & & FYO-12SA & & & & & & & & & \\
\hline $\begin{array}{c}\text { Unload } \\
\text { No. }\end{array}$ & $\begin{array}{c}\text { No. } \\
\text { Data } \\
\text { Points } \\
\end{array}$ & $\begin{array}{c}\text { Loadline } \\
\text { Slope } \\
\text { (lb/in) } \\
\end{array}$ & $\begin{array}{l}\text { COD } \\
\text { Slope } \\
\text { (lb/in) }\end{array}$ & Corr. & $\begin{array}{c}\text { Plastic } \\
\text { Area } \\
\text { (in-lb) }\end{array}$ & $\begin{array}{l}\text { Load } \\
\text { (lb.) }\end{array}$ & Loadline & $\begin{array}{l}\text { COD } \\
\text { (in.) }\end{array}$ & $\begin{array}{c}\text { Delta } \\
\text { a } \\
\text { (in.) }\end{array}$ & $\begin{array}{c}J \\
\left(i n-l b / i^{2}\right)\end{array}$ & $\begin{array}{c}\text { J } \\
\text { Plastic } \\
\left(\mathrm{in}-\mathrm{lb} / \mathrm{in}^{2}\right)\end{array}$ \\
\hline 4 & 44 & 11707145.2 & 10121711.1 & 0.99959 & 12.1 & 24718.8 & 0.00234 & 0.0026 & -0.00156 & 48 & 20.1 \\
\hline 5 & 47 & 9557465.3 & 10009092.6 & 0.99986 & 19.2 & 30148.2 & 0.00287 & 0.00331 & -0.00659 & 69.4 & 28.8 \\
\hline 6 & 48 & 9471299.4 & 10237968.1 & 0.9999 & 9.2 & 38982.4 & 0.00374 & 0.00448 & 0.00227 & 86.5 & 16.1 \\
\hline 7 & 51 & 9536447.1 & 10059908.8 & 0.99988 & 25.4 & 49927.4 & 0.00487 & 0.00603 & 0.00209 & 152.1 & 36.7 \\
\hline 8 & 54 & 9107879.1 & 9985361.5 & 0.99994 & 67.3 & 59459.4 & 0.006 & 0.00775 & 0.00146 & 253.1 & 89.9 \\
\hline 9 & 67 & 9037268.7 & 9997426.3 & 0.99994 & 109.1 & 66002.4 & 0.00709 & 0.00941 & 0.00445 & 347.2 & 143.7 \\
\hline 10 & 93 & 8736515.8 & 9864483.7 & 0.99996 & 138.3 & 68130.2 & 0.00759 & 0.01013 & 0.0018 & 395.4 & 180.8 \\
\hline 11 & 97 & 8678076.5 & 9829879.2 & 0.99997 & 168.9 & 70400.8 & 0.00823 & 0.01099 & 0.00422 & 451.4 & 220.1 \\
\hline 12 & 80 & 8524456.9 & 9751349.7 & 0.99997 & 221 & 72517.2 & 0.00895 & 0.01194 & 0.00618 & 534.9 & 287.6 \\
\hline 13 & 98 & 8487294.7 & 9693863.1 & 0.99995 & 272.1 & 74321.8 & 0.00988 & 0.01316 & 0.00993 & 618.4 & 354.6 \\
\hline 14 & 95 & 8424739 & 9603447.7 & 0.99996 & 343.4 & 75579.8 & 0.01079 & 0.01429 & 0.01369 & 726.6 & 449.7 \\
\hline 15 & 56 & 8352693 & 9512307.4 & 0.99994 & 422.5 & 76735.6 & 0.01178 & 0.01554 & 0.0192 & 849.4 & 557.3 \\
\hline 16 & 60 & 8214421 & 9439541 & 0.99994 & 512.9 & 77293.2 & 0.01286 & 0.01686 & 0.023 & 983.5 & 682.4 \\
\hline 17 & 59 & 8048762.2 & 9251871.2 & 0.99978 & 626.9 & 77457.8 & 0.01427 & 0.01835 & 0.03768 & 1172.6 & 850.1 \\
\hline 18 & 60 & 7940704.9 & 9104203.9 & 0.99978 & 712 & 77137.8 & 0.01525 & 0.01975 & 0.04316 & 1306.5 & 978.5 \\
\hline 19 & 66 & 7770095.8 & 8996885.6 & 0.9997 & 787.3 & 76341.4 & 0.01615 & 0.02066 & 0.05034 & 1427.9 & 1095.7 \\
\hline 20 & 56 & 7761336.5 & 9055291.9 & 0.99994 & 854.7 & 75433.8 & 0.01693 & 0.02175 & 0.05373 & 1532.1 & 1202.5 \\
\hline 21 & 58 & 7536374.5 & 8811559.3 & 0.99996 & 1017.7 & 73616.4 & 0.01833 & 0.02295 & 0.06511 & 1807.1 & 1475 \\
\hline
\end{tabular}




\begin{tabular}{|c|c|c|c|c|c|c|c|c|c|c|c|c|c|c|c|c|}
\hline $\begin{array}{c}\text { Unload } \\
\text { No. }\end{array}$ & $\begin{array}{c}\text { No. of } \\
\text { Data } \\
\text { Points }\end{array}$ & $\begin{array}{l}\text { COD } \\
\text { (in.) }\end{array}$ & $\begin{array}{l}\text { COD } \\
\text { Slope } \\
\text { (lb/in) }\end{array}$ & $\begin{array}{l}\text { COD } \\
\text { Corr. }\end{array}$ & $\begin{array}{c}\text { Loadline } \\
\text { Disp. } \\
\text { (in.) } \\
\end{array}$ & $\begin{array}{c}\text { Loadline } \\
\text { Slope } \\
\text { (lb/in) }\end{array}$ & $\begin{array}{c}\text { Loadline } \\
\text { Corr. }\end{array}$ & $\begin{array}{l}\text { Load } \\
\text { (lb.) }\end{array}$ & $\begin{array}{c}\text { COD } \\
\text { Area } \\
(i n-l b)\end{array}$ & $\begin{array}{c}\text { LL } \\
\text { Area } \\
(\text { in }-1 \mathrm{lb})\end{array}$ & $\begin{array}{c}\text { Crack } \\
\text { Length } \\
\text { (in.) }\end{array}$ & $\begin{array}{c}\text { Crack } \\
\text { Extension } \\
\text { (in.) }\end{array}$ & $\begin{array}{c}J \\
\left(i n-l b / i n^{2}\right)\end{array}$ & $\begin{array}{c}\text { J } \\
\text { Plastic } \\
\left(\mathrm{in}-\mathrm{lb} / \mathrm{in}^{2}\right)\end{array}$ & $\begin{array}{c}\text { CTOD } \\
\text { (in.) }\end{array}$ & $\begin{array}{c}\text { CTOD } \\
\text { Plastic } \\
\text { (in.) }\end{array}$ \\
\hline 1 & 79 & 0.0038 & 449080 & 0.9997 & 0.0038 & 449080 & 0.9997 & 1974 & -0 & -0 & 1.1927 & -0.0025 & 14 & 0 & -0.0001 & -0.0002 \\
\hline 2 & 68 & 0.0037 & 449493 & 0.9996 & 0.0037 & 449493 & 0.9996 & 1921 & 0 & 0 & 1.1924 & -0.0028 & 14 & 1 & -0.0000 & -0.0001 \\
\hline 3 & 146 & 0.0064 & 448523 & 0.9999 & 0.0064 & 448523 & 0.9999 & 3007 & 1 & 1 & 1.1932 & -0.0021 & 35 & 3 & 0.0002 & -0.0001 \\
\hline 4 & 123 & 0.0093 & 448056 & 0.9998 & 0.0093 & 448056 & 0.9998 & 3968 & 4 & 4 & 1.1935 & -0.0017 & 68 & 12 & 0.0005 & 0.0001 \\
\hline 5 & 99 & 0.0130 & 446203 & 0.9996 & 0.0130 & 446203 & 0.9996 & 4962 & 11 & 11 & 1.1949 & -0.0003 & 125 & 36 & 0.0012 & 0.0006 \\
\hline 6 & 100 & 0.0154 & 445540 & 0.9995 & 0.0154 & 445540 & 0.9995 & 5452 & 17 & 17 & 1.1955 & 0.0002 & 166 & 59 & 0.0017 & 0.0009 \\
\hline 7 & 98 & 0.0185 & 444139 & 0.9996 & 0.0185 & 444139 & 0.9996 & 5934 & 28 & 28 & 1.1965 & 0.0013 & 225 & 98 & 0.0024 & 0.0015 \\
\hline 8 & 104 & 0.0235 & 442661 & 0.9996 & 0.0235 & 442661 & 0.9996 & 6538 & 52 & 52 & 1.1977 & 0.0024 & 332 & 177 & 0.0036 & 0.0025 \\
\hline 9 & 103 & 0.0262 & 441521 & 0.9996 & 0.0262 & 441521 & 0.9996 & 6790 & 66 & 66 & 1.1986 & 0.0033 & 392 & 225 & 0.0042 & 0.0030 \\
\hline 10 & 100 & 0.0293 & 440743 & 0.9996 & 0.0293 & 440743 & 0.9996 & 7023 & 83 & 83 & 1.1992 & 0.0039 & 464 & 285 & 0.0050 & 0.0037 \\
\hline 11 & 98 & 0.0321 & 439995 & 0.9995 & 0.0321 & 439995 & 0.9995 & 7188 & 101 & 101 & 1.1997 & 0.0045 & 533 & 345 & 0.0058 & 0.0044 \\
\hline 12 & 99 & 0.0347 & 439312 & 0.9995 & 0.0347 & 439312 & 0.9995 & 7287 & 118 & 118 & 1.2003 & 0.0050 & 599 & 405 & 0.0065 & 0.0051 \\
\hline 13 & 99 & 0.0379 & 437400 & 0.9995 & 0.0379 & 437400 & 0.9995 & 7423 & 139 & 139 & 1.2017 & 0.0065 & 678 & 475 & 0.0073 & 0.0058 \\
\hline 14 & 100 & 0.0409 & 436055 & 0.9994 & 0.0409 & 436055 & 0.9994 & 7511 & 160 & 160 & 1.2028 & 0.0076 & 756 & 547 & 0.0081 & 0.0066 \\
\hline 15 & 98 & 0.0430 & 434974 & 0.9994 & 0.0430 & 434974 & 0.9994 & 7592 & 174 & 174 & 1.2036 & 0.0084 & 809 & 595 & 0.0087 & 0.0071 \\
\hline 16 & 119 & 0.0458 & 433996 & 0.9996 & 0.0458 & 433996 & 0.9996 & 7680 & 194 & 194 & 1.2044 & 0.0092 & 883 & 663 & 0.0094 & 0.0078 \\
\hline 17 & 154 & 0.0486 & 431960 & 0.9999 & 0.0486 & 431960 & 0.9999 & 7749 & 214 & 214 & 1.2060 & 0.0108 & 956 & 731 & 0.0102 & 0.0086 \\
\hline 18 & 152 & 0.0517 & 432275 & 0.9998 & 0.0517 & 432275 & 0.9998 & 7800 & 237 & 237 & 1.2058 & 0.0105 & 1038 & 811 & 0.0110 & 0.0094 \\
\hline 19 & 155 & 0.0542 & 429701 & 0.9997 & 0.0542 & 429701 & 0.9997 & 7845 & 256 & 256 & 1.2078 & 0.0126 & 1106 & 874 & 0.0117 & 0.0101 \\
\hline 20 & 152 & 0.0570 & 427041 & 0.9998 & 0.0570 & 427041 & 0.9998 & 7864 & 277 & 277 & 1.2099 & 0.0147 & 1180 & 945 & 0.0125 & 0.0108 \\
\hline 21 & 135 & 0.0607 & 423554 & 0.9999 & 0.0607 & 423554 & 0.9999 & 7876 & 305 & 305 & 1.2126 & 0.0174 & 1276 & 1038 & 0.0135 & 0.0118 \\
\hline 22 & 127 & 0.0636 & 420856 & 0.9997 & 0.0636 & 420856 & 0.9997 & 7910 & 326 & 326 & 1.2148 & 0.0196 & 1352 & 1109 & 0.0143 & 0.0126 \\
\hline 23 & 131 & 0.0671 & 416491 & 0.9997 & 0.0671 & 416491 & 0.9997 & 7894 & 354 & 354 & 1.2183 & 0.0231 & 1444 & 1199 & 0.0154 & 0.0136 \\
\hline 24 & 135 & 0.0705 & 412247 & 0.9998 & 0.0705 & 412247 & 0.9998 & 7887 & 379 & 379 & 1.2217 & 0.0265 & 1529 & 1281 & 0.0163 & 0.0145 \\
\hline 25 & 135 & 0.0745 & 405722 & 0.9998 & 0.0745 & 405722 & 0.9998 & 7846 & 410 & 410 & 1.2270 & 0.0318 & 1630 & 1379 & 0.0175 & 0.0157 \\
\hline 26 & 136 & 0.0779 & 401150 & 0.9997 & 0.0779 & 401150 & 0.9997 & 7804 & 436 & 436 & 1.2308 & 0.0355 & 1713 & 1461 & 0.0184 & 0.0166 \\
\hline 27 & 133 & 0.0817 & 394812 & 0.9996 & 0.0817 & 394812 & 0.9996 & 7744 & 465 & 465 & 1.2360 & 0.0408 & 1806 & 1553 & 0.0196 & 0.0178 \\
\hline 28 & 136 & 0.0844 & 390005 & 0.9997 & 0.0844 & 390005 & 0.9997 & 7741 & 484 & 484 & 1.2400 & 0.0448 & 1870 & 1612 & 0.0204 & 0.0185 \\
\hline 29 & 141 & 0.0873 & 386649 & 0.9997 & 0.0873 & 386649 & 0.9997 & 7747 & 505 & 505 & 1.2428 & 0.0476 & 1939 & 1678 & 0.0212 & 0.0193 \\
\hline 30 & 134 & 0.0909 & 382407 & 0.9997 & 0.0909 & 382407 & 0.9997 & 7714 & 532 & 532 & 1.2464 & 0.0512 & 2029 & 1766 & 0.0222 & 0.0203 \\
\hline 31 & 130 & 0.0942 & 379360 & 0.9997 & 0.0942 & 379360 & 0.9997 & 7691 & 556 & 556 & 1.2490 & 0.0538 & 2111 & 1847 & 0.0232 & 0.0213 \\
\hline 32 & 128 & 0.0973 & 374065 & 0.9996 & 0.0973 & 374065 & 0.9996 & 7619 & 581 & 581 & 1.2535 & 0.0583 & 2187 & 1923 & 0.0241 & 0.0222 \\
\hline 33 & 128 & 0.1007 & 367684 & 0.9996 & 0.1007 & 367684 & 0.9996 & 7553 & 606 & 606 & 1.2591 & 0.0638 & 2263 & 1997 & 0.0252 & 0.0233 \\
\hline 34 & 126 & 0.1040 & 363020 & 0.9996 & 0.1040 & 363020 & 0.9996 & 7516 & 629 & 629 & 1.2631 & 0.0679 & 2336 & 2069 & 0.0261 & 0.0242 \\
\hline 35 & 125 & 0.1077 & 357628 & 0.9995 & 0.1077 & 357628 & 0.9995 & 7427 & 657 & 657 & 1.2679 & 0.0727 & 2420 & 2153 & 0.0273 & 0.0253 \\
\hline 36 & 127 & 0.1115 & 34996.5 & 0.9995 & 0.1115 & 349965 & 0.9995 & 7257 & 686 & 686 & 1.2747 & 0.0795 & 2499 & 2237 & 0.0285 & 0.0266 \\
\hline 37 & 127 & 0.1153 & 340965 & 0.9993 & 0.1153 & 340965 & 0.9993 & 7068 & 715 & 715 & 1.2829 & 0.0876 & 2570 & 2312 & 0.0297 & 0.0279 \\
\hline 38 & 127 & 0.1191 & 327950 & 0.9993 & 0.1191 & 327950 & 0.9993 & 6867 & 742 & 742 & 1.2949 & 0.0996 & 2623 & 2366 & 0.0311 & 0.0292 \\
\hline 39 & 136 & 0.1228 & 318374 & 0.9992 & 0.1228 & 318374 & 0.9992 & 6727 & 765 & 765 & 1.3039 & 0.1087 & 2672 & 2415 & 0.0322 & 0.0304 \\
\hline
\end{tabular}




\begin{tabular}{|c|c|c|c|c|c|c|c|c|c|c|c|c|c|c|c|c|}
\hline $\begin{array}{l}\text { Unload } \\
\text { No. }\end{array}$ & $\begin{array}{c}\text { No. of } \\
\text { Data } \\
\text { Points }\end{array}$ & $\begin{array}{l}\text { COD } \\
\text { (in.) }\end{array}$ & $\begin{array}{l}\text { COD } \\
\text { Slope } \\
\text { (lb/in) }\end{array}$ & $\begin{array}{l}\text { COD } \\
\text { Corr. }\end{array}$ & $\begin{array}{l}\text { Loadline } \\
\text { Disp. } \\
\text { (in.) }\end{array}$ & $\begin{array}{c}\text { Loadline } \\
\text { Slope } \\
\text { (lb/in) }\end{array}$ & $\begin{array}{c}\text { Loadline } \\
\text { Corr. }\end{array}$ & $\begin{array}{l}\text { Load } \\
\text { (lb.) }\end{array}$ & $\begin{array}{c}\text { COD } \\
\text { Area } \\
(\text { in-lb) }\end{array}$ & $\begin{array}{c}\mathrm{LL} \\
\text { Area } \\
\text { (in-lb) }\end{array}$ & $\begin{array}{c}\text { Crack } \\
\text { Length } \\
\text { (in.) }\end{array}$ & $\begin{array}{c}\text { Crack } \\
\text { Extension } \\
\text { (in.) }\end{array}$ & $\begin{array}{c}\mathrm{J} \\
\left(\mathrm{in}-\mathrm{lb} / \mathrm{in}^{2}\right)\end{array}$ & $\begin{array}{c}\mathrm{J} \\
\text { Plastic } \\
\left(\mathrm{in}-\mathrm{lb} / \mathrm{in}^{2}\right)\end{array}$ & $\begin{array}{l}\text { CIOD } \\
\text { (in.) }\end{array}$ & $\begin{array}{c}\text { CTOD } \\
\text { Plastic } \\
\text { (in.) }\end{array}$ \\
\hline 40 & 131 & 0.1259 & 309780 & 0.9993 & 0.1259 & 309780 & 0.9993 & 6604 & 785 & 785 & 1.3121 & 0.1169 & 2712 & 2455 & 0.0333 & 0.0314 \\
\hline 41 & 139 & 0.1291 & 303800 & 0.9993 & 0.1291 & 303800 & 0.9993 & 6562 & 803 & 803 & 1.3179 & 0.1227 & 2760 & 2499 & 0.0342 & 0.0323 \\
\hline 42 & 137 & 0.1320 & 299832 & 0.9993 & 0.1320 & 299832 & 0.9993 & 6491 & 821 & 821 & 1.3218 & 0.1266 & 2814 & 2554 & 0.0351 & 0.0332 \\
\hline 43 & 140 & 0.1357 & 293224 & 0.9994 & 0.1357 & 293224 & 0.9994 & 6409 & 845 & 845 & 1.3284 & 0.1332 & 2880 & 2618 & 0.0363 & 0.0345 \\
\hline 44 & 144 & 0.1393 & 287417 & 0.9993 & 0.1393 & 287417 & 0.9993 & 6292 & 867 & 867 & 1.3342 & 0.1390 & 2939 & 2680 & 0.0375 & 0.0356 \\
\hline 45 & 143 & 0.1422 & 284406 & 0.9993 & 0.1422 & 284406 & 0.9993 & 6252 & 884 & 884 & 1.3373 & 0.1421 & 2991 & 2731 & 0.0383 & 0.0365 \\
\hline
\end{tabular}




\begin{tabular}{|c|c|c|c|c|c|c|c|c|c|c|c|c|c|c|c|c|}
\hline $\begin{array}{l}\text { Unload } \\
\text { No. }\end{array}$ & $\begin{array}{c}\text { No. of } \\
\text { Data } \\
\text { Points }\end{array}$ & $\begin{array}{l}\text { COD } \\
\text { (in.) }\end{array}$ & $\begin{array}{l}\text { COD } \\
\text { Slope } \\
\text { (lb/in) }\end{array}$ & $\begin{array}{l}\text { COD } \\
\text { Corr. }\end{array}$ & $\begin{array}{c}\text { Loadline } \\
\text { Disp. } \\
\text { (in.) } \\
\end{array}$ & $\begin{array}{c}\text { Loadline } \\
\text { Slope } \\
\text { (lb/in) } \\
\end{array}$ & $\begin{array}{l}\text { Loadline } \\
\text { Corr. }\end{array}$ & $\begin{array}{l}\text { Load } \\
\text { (lb.) }\end{array}$ & $\begin{array}{c}\text { COD } \\
\text { Area } \\
(\mathrm{in}-1 \mathrm{~b})\end{array}$ & $\begin{array}{c}\text { LL } \\
\text { Area } \\
(\text { in-lb) }\end{array}$ & $\begin{array}{c}\text { Crack } \\
\text { Length } \\
\text { (in.) } \\
\end{array}$ & $\begin{array}{c}\text { Crack } \\
\text { Extension } \\
\text { (in.) }\end{array}$ & $\begin{array}{c}J \\
\left(\mathrm{in}-\mathrm{lb} / \mathrm{in}^{2}\right)\end{array}$ & $\begin{array}{c}\text { J } \\
\text { Plastic } \\
\left(\text { in-lb/in }{ }^{2}\right)\end{array}$ & $\begin{array}{l}\text { CTOD } \\
\text { (in.) }\end{array}$ & $\begin{array}{l}\text { CTOD } \\
\text { Plastic } \\
\text { (in.) }\end{array}$ \\
\hline 1 & 156 & 0.0041 & 450967 & 0.9999 & 0.0041 & 450967 & 0.9999 & 1982 & $\mathbf{0}$ & 0 & 1.1913 & -0.0018 & 14 & -0 & 0.0000 & -0.0001 \\
\hline 2 & 155 & 0.0054 & 451842 & 0.9999 & 0.0054 & 451842 & 0.9999 & 2504 & 0 & 0 & 1.1906 & -0.0025 & 23 & 1 & 0.0001 & -0.0001 \\
\hline 3 & 167 & 0.0065 & 452000 & 0.9998 & 0.0065 & 452000 & 0.9998 & 2983 & 1 & 1 & 1.1905 & -0.0026 & 33 & 2 & 0.0002 & -0.0000 \\
\hline 4 & 171 & 0.0074 & 451689 & 0.9999 & 0.0074 & 451689 & 0.9999 & 3297 & 1 & 1 & 1.1907 & -0.0024 & 42 & 3 & 0.0003 & 0.0000 \\
\hline 5 & 162 & 0.0085 & 450532 & 0.9999 & 0.0085 & 450532 & 0.9999 & 3689 & 2 & 2 & 1.1916 & -0.0015 & 54 & 6 & 0.0004 & 0.0001 \\
\hline 6 & 138 & 0.0100 & 450603 & 0.9999 & 0.0100 & 450603 & 0.9999 & 4188 & 3 & 3 & 1.1916 & -0.0016 & 73 & 11 & 0.0006 & 0.0002 \\
\hline 7 & 124 & 0.0112 & 449362 & 0.9998 & 0.0112 & 449362 & 0.9998 & 4529 & 5 & 5 & 1.1925 & -0.0006 & 91 & 18 & 0.0009 & 0.0003 \\
\hline 8 & 122 & 0.0129 & 448262 & 0.9997 & 0.0129 & 448262 & 0.9997 & 4970 & 9 & 9 & 1.1934 & 0.0002 & 117 & 29 & 0.0012 & 0.0005 \\
\hline 9 & 122 & 0.0142 & 447845 & 0.9998 & 0.0142 & 447845 & 0.9998 & 5280 & 12 & 12 & 1.1937 & 0.0006 & 139 & 40 & 0.0014 & 0.0007 \\
\hline 10 & 122 & 0.0157 & 447221 & 0.9998 & 0.0157 & 447221 & 0.9998 & 5570 & 16 & 16 & 1.1942 & 0.0010 & 165 & 55 & 0.0017 & 0.0009 \\
\hline 11 & 117 & 0.0173 & 446732 & 0.9997 & 0.0173 & 446732 & 0.9997 & 5847 & 22 & 22 & 1.1945 & 0.0014 & 197 & 74 & 0.0021 & 0.0012 \\
\hline 12 & 124 & 0.0185 & 447014 & 0.9997 & 0.0185 & 447014 & 0.9997 & 6065 & 26 & 26 & 1.1943 & 0.0012 & 220 & 88 & 0.0023 & 0.0014 \\
\hline 13 & 121 & 0.0196 & 446163 & 0.9997 & 0.0196 & 446163 & 0.9997 & 6235 & 31 & 31 & 1.1950 & 0.0018 & 244 & 105 & 0.0026 & 0.0016 \\
\hline 14 & 126 & 0.0210 & 445653 & 0.9997 & 0.0210 & 445653 & 0.9997 & 6393 & 37 & 37 & 1.1954 & 0.0022 & 273 & 126 & 0.0029 & 0.0019 \\
\hline 15 & 125 & 0.0225 & 444586 & 0.9997 & 0.0225 & 444586 & 0.9997 & 6598 & 43 & 43 & 1.1962 & 0.0031 & 305 & 148 & 0.0033 & 0.0021 \\
\hline 16 & 129 & 0.0242 & 444148 & 0.9997 & 0.0242 & 444148 & 0.9997 & 6767 & 52 & 52 & 1.1965 & 0.0034 & 344 & 179 & 0.0037 & 0.0025 \\
\hline 17 & 130 & 0.0259 & 443878 & 0.9997 & 0.0259 & 443878 & 0.9997 & 6918 & 62 & 62 & 1.1967 & 0.0036 & 383 & 210 & 0.0041 & 0.0029 \\
\hline 18 & 126 & 0.0277 & 443644 & 0.9997 & 0.0277 & 443644 & 0.9997 & 7049 & 72 & 72 & 1.1969 & 0.0038 & 425 & 246 & 0.0046 & 0.0033 \\
\hline 19 & 127 & 0.0296 & 442570 & 0.9997 & 0.0296 & 442570 & 0.9997 & 7190 & 84 & 84 & 1.1977 & 0.0046 & 474 & 287 & 0.0051 & 0.0038 \\
\hline 20 & 128 & 0.0313 & 441745 & 0.9997 & 0.0313 & 441745 & 0.9997 & 7328 & 93 & 93 & 1.1984 & 0.0052 & 514 & 319 & 0.0055 & 0.0041 \\
\hline 21 & 124 & 0.0338 & 440755 & 0.9997 & 0.0338 & 440755 & 0.9997 & 7426 & 111 & 111 & 1.1991 & 0.0060 & 579 & 378 & 0.0062 & 0.0048 \\
\hline 22 & 127 & 0.0355 & 442776 & 0.9993 & 0.0355 & 442776 & 0.9993 & 7558 & 120 & 120 & 1.1976 & 0.0045 & 620 & 413 & 0.0066 & 0.0051 \\
\hline 23 & 125 & 0.0379 & 441223 & 0.9996 & 0.0379 & 441223 & 0.9996 & 7635 & 138 & 138 & 1.1988 & 0.0057 & 686 & 473 & 0.0073 & 0.0058 \\
\hline 24 & 126 & 0.0403 & 438583 & 0.9995 & 0.0403 & 438583 & 0.9995 & 7733 & 154 & 154 & 1.2008 & 0.0077 & 746 & 526 & 0.0079 & 0.0064 \\
\hline 25 & 125 & 0.0425 & 436811 & 0.9996 & 0.0425 & 436811 & 0.9996 & 7789 & 170 & 170 & 1.2022 & 0.0091 & 804 & 581 & 0.0086 & 0.0069 \\
\hline 26 & 124 & 0.0447 & 435462 & 0.9996 & 0.0447 & 435462 & 0.9996 & 7880 & 185 & 185 & 1.2033 & 0.0101 & 860 & 630 & 0.0091 & 0.0075 \\
\hline 27 & 146 & 0.0473 & 433312 & 0.9997 & 0.0473 & 433312 & 0.9997 & 7923 & 204 & 204 & 1.2049 & 0.0118 & 930 & 696 & 0.0098 & 0.0082 \\
\hline 28 & 162 & 0.0506 & 431654 & 0.9999 & 0.0506 & 431654 & 0.9999 & 7989 & 229 & 229 & 1.2062 & 0.0131 & 1019 & 780 & 0.0107 & 0.0090 \\
\hline 29 & 170 & 0.0562 & 428343 & 0.9998 & 0.0562 & 428343 & 0.9998 & 8065 & 273 & 273 & 1.2088 & 0.0157 & 1176 & 929 & 0.0123 & 0.0106 \\
\hline 30 & 160 & 0.0588 & 427422 & 0.9998 & 0.0588 & 427422 & 0.9998 & 8136 & 291 & 291 & 1.2096 & 0.0164 & 1244 & 992 & 0.0130 & 0.0112 \\
\hline 31 & 165 & 0.0615 & 426853 & 0.9998 & 0.0615 & 426853 & 0.9998 & 8167 & 313 & 313 & 1.2100 & 0.0169 & 1320 & 1067 & 0.0138 & 0.0119 \\
\hline 32 & 161 & 0.0645 & 423365 & 0.9997 & 0.0645 & 423365 & 0.9997 & 8191 & 336 & 336 & 1.2128 & 0.0197 & 1401 & 1143 & 0.0146 & 0.0128 \\
\hline 33 & 163 & 0.0677 & 419478 & 0.9998 & 0.0677 & 419478 & 0.9998 & 8212 & 361 & 361 & 1.2159 & 0.0228 & 1488 & 1225 & 0.0155 & 0.0136 \\
\hline 34 & 167 & 0.0698 & 417768 & 0.9998 & 0.0698 & 417768 & 0.9998 & 8240 & 377 & 377 & 1.2173 & 0.0241 & 1542 & 1277 & 0.0161 & 0.0142 \\
\hline 35 & 164 & 0.0729 & 414684 & 0.9998 & 0.0729 & 414684 & 0.9998 & 8227 & 402 & 402 & 1.2197 & 0.0266 & 1628 & 1361 & 0.0170 & 0.0151 \\
\hline 36 & 164 & 0.0756 & 412417 & 0.9998 & 0.0756 & 412417 & 0.9998 & 8248 & 423 & 423 & 1.2216 & 0.0284 & 1700 & 1429 & 0.0177 & 0.0158 \\
\hline 37 & 163 & 0.0784 & 410008 & 0.9998 & 0.0784 & 410008 & 0.9998 & 8235 & 445 & 445 & 1.2235 & 0.0304 & 1777 & 1504 & 0.0185 & 0.0166 \\
\hline 38 & 167 & 0.0808 & 406843 & 0.9998 & 0.0808 & 406843 & 0.9998 & 8200 & 465 & 465 & 1.2261 & 0.0330 & 1842 & 1569 & 0.0193 & 0.0173 \\
\hline 39 & 175 & 0.0836 & 402562 & 0.9998 & 0.0836 & 402562 & 0.9998 & 81.57 & 488 & 488 & 1.2296 & 0.0365 & 1912 & 1638 & 0.0201 & 0.0181 \\
\hline
\end{tabular}




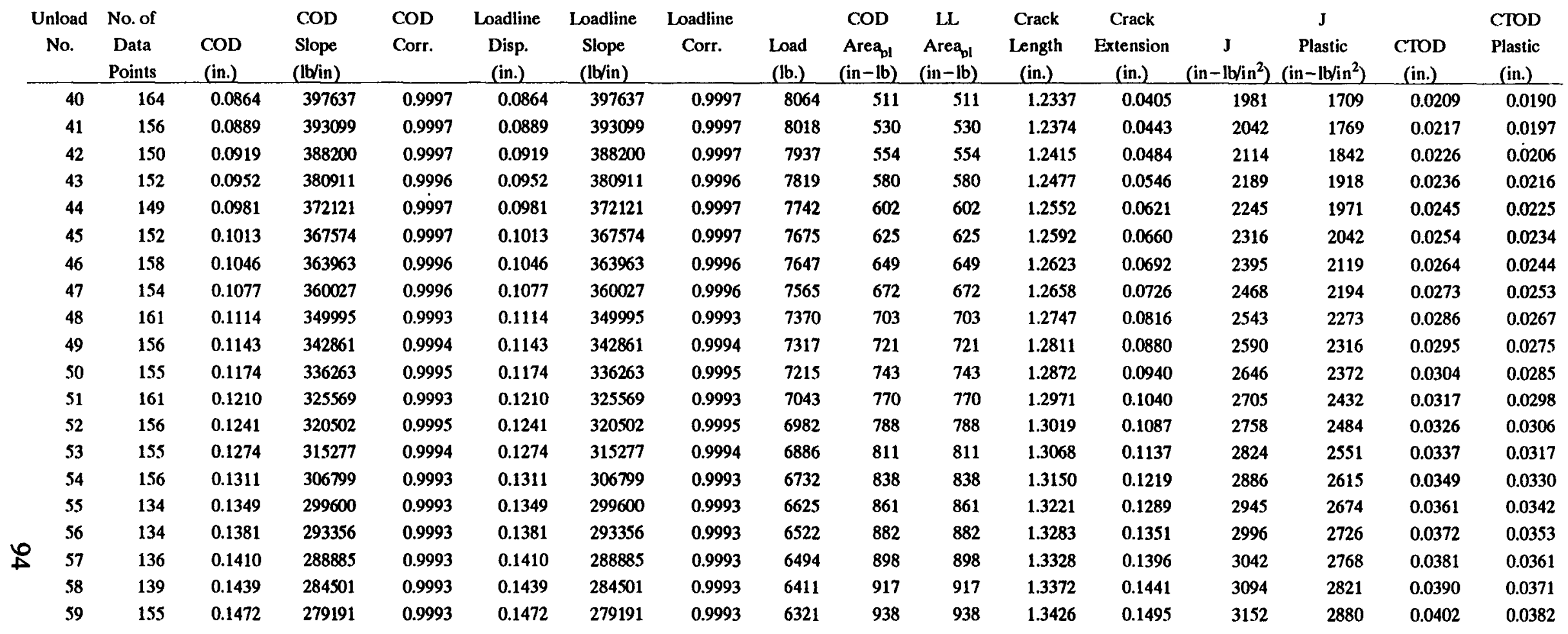




\begin{tabular}{|c|c|c|c|c|c|c|c|c|c|c|c|c|c|c|c|c|}
\hline $\begin{array}{c}\text { Unload } \\
\text { No. }\end{array}$ & $\begin{array}{c}\text { No. of } \\
\text { Data } \\
\text { Points }\end{array}$ & $\begin{array}{l}\text { COD } \\
\text { (in.) }\end{array}$ & $\begin{array}{l}\text { COD } \\
\text { Slope } \\
\text { (lb/in) }\end{array}$ & $\begin{array}{l}\text { COD } \\
\text { Corr. }\end{array}$ & $\begin{array}{c}\text { Loadline } \\
\text { Disp. } \\
\text { (in.) }\end{array}$ & $\begin{array}{c}\text { Loadline } \\
\text { Slope } \\
\text { (lb/in) }\end{array}$ & $\begin{array}{c}\text { Loadline } \\
\text { Corr. }\end{array}$ & $\begin{array}{l}\text { Load } \\
\text { (lb.) }\end{array}$ & $\begin{array}{c}\text { COD } \\
\text { Area } \\
(\text { in }-1 b) \\
\end{array}$ & $\begin{array}{c}L L \\
\text { Area } \\
\text { (in-lb) }\end{array}$ & $\begin{array}{c}\text { Crack } \\
\text { Length } \\
\text { (in.) }\end{array}$ & $\begin{array}{c}\text { Crack } \\
\text { Extension } \\
\text { (in.) } \\
\end{array}$ & $\begin{array}{c}J \\
\left(\mathrm{in}-\mathrm{lb} / \mathrm{in}^{2}\right)\end{array}$ & $\begin{array}{c}\mathrm{J} \\
\text { Plastic } \\
\left(\mathrm{in}-\mathrm{lb} / \mathrm{in}^{2}\right)\end{array}$ & $\begin{array}{c}\text { CTOD } \\
\text { (in.) }\end{array}$ & $\begin{array}{c}\text { CTOD } \\
\text { Plastic } \\
\text { (in.) }\end{array}$ \\
\hline 1 & 1.52 & 0.0042 & 452812 & 0.9996 & 0.0042 & 452812 & 0.9996 & 1994 & 0 & 0 & 1.1899 & -0.0039 & 14 & -0 & 0.0000 & -0.0001 \\
\hline 2 & 156 & 0.0056 & 451119 & 0.9998 & 0.0056 & 451119 & 0.9998 & 2640 & 0 & 0 & 1.1912 & -0.0026 & 25 & 1 & 0.0001 & -0.0001 \\
\hline 3 & 172 & 0.0070 & 451380 & 0.9999 & 0.0070 & 451380 & 0.9999 & 3152 & 1 & 1 & 1.1910 & -0.0028 & 38 & 2 & 0.0003 & 0.0000 \\
\hline 4 & 169 & 0.0080 & 451178 & 0.9998 & 0.0080 & 451178 & 0.9998 & 3521 & 1 & 1 & 1.1911 & -0.0026 & 48 & 5 & 0.0004 & 0.0001 \\
\hline 5 & 147 & 0.0094 & 449826 & 0.9998 & 0.0094 & 449826 & 0.9998 & 3995 & 3 & 3 & 1.1922 & -0.0016 & 66 & 9 & 0.0006 & 0.0001 \\
\hline 6 & 129 & 0.0108 & 449003 & 0.9998 & 0.0108 & 449003 & 0.9998 & 4417 & 5 & 5 & 1.1928 & -0.0010 & 85 & 16 & 0.0008 & 0.0003 \\
\hline 7 & 127 & 0.0119 & 448261 & 0.9998 & 0.0119 & 448261 & 0.9998 & 4723 & 7 & 7 & 1.1934 & -0.0004 & 103 & 23 & 0.0010 & 0.0004 \\
\hline 8 & 125 & 0.0132 & 447919 & 0.9998 & 0.0132 & 447919 & 0.9998 & 5029 & 9 & 9 & 1.1936 & -0.0001 & 122 & 32 & 0.0012 & 0.0006 \\
\hline 9 & 124 & 0.0144 & 447707 & 0.9997 & 0.0144 & 447707 & 0.9997 & 5306 & 13 & 13 & 1.1938 & 0.0000 & 143 & 43 & 0.0014 & 0.0007 \\
\hline 10 & 129 & 0.0158 & 446274 & 0.9997 & 0.0158 & 446274 & 0.9997 & 5588 & 17 & 17 & 1.1949 & 0.0011 & 169 & 58 & 0.0018 & 0.0009 \\
\hline 11 & 129 & 0.0170 & 446332 & 0.9997 & 0.0170 & 446332 & 0.9997 & 5801 & 20 & 20 & 1.1948 & 0.0011 & 191 & 70 & 0.0020 & 0.0011 \\
\hline 12 & 129 & 0.0180 & 446852 & 0.9997 & 0.0180 & 446852 & 0.9997 & 5966 & 25 & 25 & 1.1944 & 0.0007 & 211 & 84 & 0.0022 & 0.0013 \\
\hline 13 & 132 & 0.0194 & 445643 & 0.9997 & 0.0194 & 445643 & 0.9997 & 6180 & 30 & 30 & 1.1954 & 0.0016 & 239 & 102 & 0.0025 & 0.0015 \\
\hline 14 & 132 & 0.0209 & 445217 & 0.9997 & 0.0209 & 445217 & 0.9997 & 6371 & 36 & 36 & 1.1957 & 0.0019 & 271 & 125 & 0.0029 & 0.0018 \\
\hline 15 & 133 & 0.0220 & 445678 & 0.9997 & 0.0220 & 445678 & 0.9997 & 6516 & 41 & 41 & 1.1953 & 0.0016 & 294 & 142 & 0.0032 & 0.0021 \\
\hline 16 & 135 & 0.0231 & 443560 & 0.9998 & 0.0231 & 443560 & 0.9998 & 6642 & 47 & 47 & 1.1970 & 0.0032 & 320 & 161 & 0.0034 & 0.0023 \\
\hline 17 & 134 & 0.0248 & 443715 & 0.9997 & 0.0248 & 443715 & 0.9997 & 6794 & 56 & 56 & 1.1969 & 0.0031 & 357 & 190 & 0.0039 & 0.0027 \\
\hline 18 & 133 & 0.0258 & 440944 & 0.9999 & 0.0258 & 440944 & 0.9999 & 6881 & 61 & 61 & 1.1990 & 0.0052 & 380 & 208 & 0.0041 & 0.0029 \\
\hline 19 & 132 & 0.0273 & 441849 & 0.9998 & 0.0273 & 441849 & 0.9998 & 7004 & 69 & 69 & 1.1983 & 0.0045 & 415 & 236 & 0.0045 & 0.0032 \\
\hline 20 & 132 & 0.0291 & 443827 & 0.9993 & 0.0291 & 443827 & 0.9993 & 7099 & 81 & 81 & 1.1968 & 0.0030 & 458 & 276 & 0.0050 & 0.0036 \\
\hline 21 & 115 & 0.0307 & 441910 & 0.9995 & 0.0307 & 441910 & 0.9995 & 7219 & 91 & 91 & 1.1982 & 0.0045 & 500 & 310 & 0.0054 & 0.0040 \\
\hline 22 & 110 & 0.0326 & 440662 & 0.9996 & 0.0326 & 440662 & 0.9996 & 7312 & 102 & 102 & 1.1992 & 0.0054 & 545 & 350 & 0.0059 & 0.0045 \\
\hline 23 & 111 & 0.0348 & 437249 & 0.9998 & 0.0348 & 437249 & 0.9998 & 7415 & 117 & 117 & 1.2019 & 0.0081 & 602 & 400 & 0.0065 & 0.0051 \\
\hline 24 & 116 & 0.0370 & 437775 & 0.9997 & 0.0370 & 437775 & 0.9997 & 7510 & 131 & 131 & 1.2015 & 0.0077 & 655 & 448 & 0.0071 & 0.0056 \\
\hline 25 & 114 & 0.0392 & 437682 & 0.9996 & 0.0392 & 437682 & 0.9996 & 7592 & 146 & 146 & 1.2015 & 0.0078 & 712 & 500 & 0.0076 & 0.0061 \\
\hline 26 & 109 & 0.0414 & 438203 & 0.9993 & 0.0414 & 438203 & 0.9993 & 7689 & 161 & 161 & 1.2011 & 0.0074 & 770 & 553 & 0.0082 & 0.0067 \\
\hline 27 & 112 & 0.0435 & 436542 & 0.9993 & 0.0435 & 436542 & 0.9993 & 7721 & 178 & 178 & 1.2024 & 0.0086 & 828 & 608 & 0.0088 & 0.0073 \\
\hline 28 & 128 & 0.0461 & 434733 & 0.9996 & 0.0461 & 434733 & 0.9996 & 7802 & 196 & 196 & 1.2038 & 0.0101 & 897 & 671 & 0.0095 & 0.0079 \\
\hline 29 & 174 & 0.0485 & 432705 & 0.9999 & 0.0485 & 432705 & 0.9999 & 7875 & 213 & 213 & 1.2054 & 0.0116 & 959 & 727 & 0.0102 & 0.0085 \\
\hline 30 & 173 & 0.0508 & 431059 & 0.9999 & 0.0508 & 431059 & 0.9999 & 7902 & 231 & 231 & 1.2067 & 0.0129 & 1021 & 786 & 0.0108 & 0.0091 \\
\hline 31 & 178 & 0.0531 & 428941 & 0.9999 & 0.0531 & 428941 & 0.9999 & 7948 & 247 & 247 & 1.2084 & 0.0146 & 1081 & 843 & 0.0115 & 0.0097 \\
\hline 32 & 174 & 0.0556 & 427440 & 0.9998 & 0.0556 & 427440 & 0.9998 & 7979 & 266 & 266 & 1.2096 & 0.0158 & 1147 & 905 & 0.0121 & 0.0104 \\
\hline 33 & 168 & 0.0575 & 426196 & 0.9998 & 0.0575 & 426196 & 0.9998 & 8024 & 280 & 280 & 1.2105 & 0.0168 & 1199 & 954 & 0.0127 & 0.0109 \\
\hline 34 & 174 & 0.0596 & 424686 & 0.9998 & 0.0596 & 424686 & 0.9998 & 8054 & 295 & 295 & 1.2117 & 0.0180 & 1253 & 1005 & 0.0132 & 0.0114 \\
\hline 35 & 171 & 0.0621 & 422198 & 0.9998 & 0.0621 & 422198 & 0.9998 & 8054 & 316 & 316 & 1.2137 & 0.0199 & 1323 & 1073 & 0.0140 & 0.0122 \\
\hline 36 & 170 & 0.0646 & 419783 & 0.9998 & 0.0646 & 419783 & 0.9998 & 8056 & 335 & 335 & 1.2156 & 0.0219 & 1388 & 1136 & 0.0147 & 0.0128 \\
\hline 37 & 171 & 0.0671 & 416595 & 0.9998 & 0.0671 & 416595 & 0.9998 & 8046 & 355 & 355 & 1.2182 & 0.0244 & 1456 & 1201 & 0.0154 & 0.0136 \\
\hline 38 & 168 & 0.0696 & 413927 & 0.9998 & 0.0696 & 413927 & 0.9998 & 8078 & 372 & 372 & 1.2203 & 0.0266 & 1519 & 1260 & 0.0161 & 0.0142 \\
\hline 39 & 167 & 0.0723 & 411483 & 0.9998 & 0.0723 & 411483 & 0.9998 & 8039 & 395 & 395 & 1.2223 & 0.0286 & 1593 & 1335 & 0.0169 & 0.0150 \\
\hline
\end{tabular}




\begin{tabular}{|c|c|c|c|c|c|c|c|c|c|c|c|c|c|c|c|c|}
\hline $\begin{array}{l}\text { Unload } \\
\text { No. }\end{array}$ & $\begin{array}{c}\text { No. of } \\
\text { Data } \\
\text { Points }\end{array}$ & $\begin{array}{l}\text { COD } \\
\text { (in.) }\end{array}$ & $\begin{array}{l}\text { COD } \\
\text { Slope } \\
\text { (lb/in) }\end{array}$ & $\begin{array}{l}\text { COD } \\
\text { Corr. }\end{array}$ & $\begin{array}{c}\text { Loadline } \\
\text { Disp. } \\
\text { (in.) }\end{array}$ & $\begin{array}{c}\text { Loadline } \\
\text { Slope } \\
\text { (lb/in) }\end{array}$ & $\begin{array}{c}\text { Loadline } \\
\text { Corr. }\end{array}$ & $\begin{array}{l}\text { Load } \\
\text { (lb.) }\end{array}$ & $\begin{array}{c}\text { COD } \\
\text { Area }_{\text {bl }} \\
\text { (in-lb) }\end{array}$ & $\begin{array}{c}L L \\
\text { Area } \\
\text { (in-lb) }\end{array}$ & $\begin{array}{c}\text { Crack } \\
\text { Length } \\
\text { (in.) } \\
\end{array}$ & $\begin{array}{c}\text { Crack } \\
\text { Extension } \\
\text { (in.) }\end{array}$ & $\begin{array}{c}J \\
\left(\mathrm{in}-\mathrm{lb} / \mathrm{in}^{2}\right)\end{array}$ & $\begin{array}{c}J \\
\text { Plastic } \\
\left(\text { in-lb/in }{ }^{2}\right)\end{array}$ & $\begin{array}{l}\text { CTOD } \\
\text { (in.) }\end{array}$ & $\begin{array}{c}\text { CTOD } \\
\text { Plastic } \\
\text { (in.) }\end{array}$ \\
\hline 40 & 169 & 0.0753 & 406198 & 0.9998 & 0.0753 & 406198 & 0.9998 & 7999 & 419 & 419 & 1.2266 & 0.0328 & 1669 & 1409 & 0.0177 & 0.0159 \\
\hline 41 & 163 & 0.0781 & 400615 & 0.9997 & 0.0781 & 400615 & 0.9997 & 7947 & 440 & 440 & 1.2312 & 0.0374 & 1735 & 1474 & 0.0186 & 0.0167 \\
\hline 42 & 162 & 0.0809 & 395526 & 0.9998 & 0.0809 & 395526 & 0.9998 & 7916 & 461 & 461 & 1.2354 & 0.0416 & 1802 & 1538 & 0.0194 & 0.0175 \\
\hline 43 & 162 & 0.0832 & 392133 & 0.9997 & 0.0832 & 392133 & 0.9997 & 7895 & 477 & 477 & 1.2382 & 0.0445 & 1856 & 1590 & 0.0200 & 0.0181 \\
\hline 44 & 167 & 0.0858 & 387051 & 0.9997 & 0.0858 & 387051 & 0.9997 & 7821 & 498 & 498 & 1.2425 & 0.0487 & 1919 & 1653 & 0.0208 & 0.0189 \\
\hline 45 & 162 & 0.0884 & 382207 & 0.9996 & 0.0884 & 382207 & 0.9996 & 7720 & 519 & 519 & 1.2466 & 0.0528 & 1982 & 1719 & 0.0216 & 0.0197 \\
\hline 46 & 166 & 0.0917 & 373821 & 0.9997 & 0.0917 & 373821 & 0.9997 & 7644 & 544 & 544 & 1.2538 & 0.0600 & 2051 & 1785 & 0.0226 & 0.0207 \\
\hline 47 & 167 & 0.0943 & 368879 & 0.9997 & 0.0943 & 368879 & 0.9997 & 7569 & 562 & 562 & 1.2580 & 0.0643 & 2107 & 1841 & 0.0234 & 0.0215 \\
\hline 48 & 168 & 0.0972 & 363169 & 0.9996 & 0.0972 & 363169 & 0.9996 & 7521 & 583 & 583 & 1.2630 & 0.0692 & 2167 & 1900 & 0.0243 & 0.0223 \\
\hline 49 & 176 & 0.1000 & 357365 & 0.9996 & 0.1000 & 357365 & 0.9996 & 7473 & 603 & 603 & 1.2681 & 0.0743 & 2227 & 1957 & 0.0251 & 0.0232 \\
\hline 50 & 167 & 0.1031 & 350474 & 0.9995 & 0.1031 & 350474 & 0.9995 & 7342 & 626 & 626 & 1.2743 & 0.0805 & 2291 & 2024 & 0.0261 & 0.0242 \\
\hline 51 & 172 & 0.1059 & 343670 & 0.9995 & 0.1059 & 343670 & 0.9995 & 7250 & 646 & 646 & 1.2804 & 0.0866 & 2344 & 2075 & 0.0270 & 0.0251 \\
\hline 52 & 171 & 0.1095 & 335728 & 0.9995 & 0.1095 & 335728 & 0.9995 & 7180 & 670 & 670 & 1.2876 & 0.0939 & 2413 & 2141 & 0.0281 & 0.0262 \\
\hline 53 & 169 & 0.1134 & 329837 & 0.9996 & 0.1134 & 329837 & 0.9996 & 7079 & 697 & 697 & 1.2931 & 0.0993 & 2494 & 2223 & 0.0293 & 0.0274 \\
\hline 54 & 148 & 0.1172 & 323559 & 0.9995 & 0.1172 & 323559 & 0.9995 & 6979 & 724 & 724 & 1.2990 & 0.1052 & 2572 & 2302 & 0.0305 & 0.0286 \\
\hline 55 & 149 & 0.1217 & 315291 & 0.9992 & 0.1217 & 315291 & 0.9992 & 6782 & 756 & 756 & 1.3068 & 0.1131 & 2659 & 2395 & 0.0320 & 0.0301 \\
\hline 56 & 147 & 0.1253 & 304423 & 0.9992 & 0.1253 & 304423 & 0.9992 & 6584 & 782 & 782 & 1.3173 & 0.1236 & 2710 & 2448 & 0.0333 & 0.0314 \\
\hline 57 & 148 & 0.1287 & 298301 & 0.9993 & 0.1287 & 298301 & 0.9993 & 6474 & 802 & 802 & 1.3234 & 0.1296 & 2760 & 2500 & 0.0343 & 0.0324 \\
\hline 58 & 157 & 0.1321 & 290393 & 0.9991 & 0.1321 & 290393 & 0.9991 & 6380 & 823 & 823 & 1.3312 & 0.1375 & 2810 & 2547 & 0.0355 & 0.0336 \\
\hline 59 & 155 & 0.1357 & 282608 & 0.9991 & 0.1357 & 282608 & 0.9991 & 6260 & 844 & 844 & 1.3391 & 0.1454 & 2859 & 2597 & 0.0367 & 0.0348 \\
\hline 60 & 153 & 0.1387 & 278112 & 0.9993 & 0.1387 & 278112 & 0.9993 & 6215 & 860 & 860 & 1.3438 & 0.1500 & 2904 & 2640 & 0.0375 & 0.0356 \\
\hline 61 & 155 & 0.1422 & 272695 & 0.9991 & 0.1422 & 272695 & 0.9991 & 6091 & 883 & 883 & 1.3494 & 0.1556 & 2964 & 2703 & 0.0387 & 0.0369 \\
\hline
\end{tabular}




\begin{tabular}{|c|c|c|c|c|c|c|c|c|c|c|c|c|c|c|c|c|}
\hline $\begin{array}{c}\text { Unload } \\
\text { No. }\end{array}$ & $\begin{array}{c}\text { No. of } \\
\text { Data } \\
\text { Points }\end{array}$ & $\begin{array}{l}\text { COD } \\
\text { (in.) }\end{array}$ & $\begin{array}{l}\text { COD } \\
\text { Slope } \\
\text { (lb/in) }\end{array}$ & $\begin{array}{l}\text { COD } \\
\text { Corr. }\end{array}$ & $\begin{array}{c}\text { Loadline } \\
\text { Disp. } \\
\text { (in.) }\end{array}$ & $\begin{array}{c}\text { Loadline } \\
\text { Slope } \\
\text { (lb/in) }\end{array}$ & $\begin{array}{c}\text { Loadline } \\
\text { Corr. }\end{array}$ & $\begin{array}{l}\text { Load } \\
\text { (lb.) }\end{array}$ & $\begin{array}{c}\text { COD } \\
\text { Area }_{\text {bl }} \\
\text { (in-lb) }\end{array}$ & $\begin{array}{c}\text { LL } \\
\text { Area }_{\text {bl }} \\
(\text { in-lb) }\end{array}$ & $\begin{array}{c}\text { Crack } \\
\text { Length } \\
\text { (in.) }\end{array}$ & $\begin{array}{c}\text { Crack } \\
\text { Extension } \\
\text { (in.) }\end{array}$ & $\begin{array}{c}J \\
\left(\mathrm{in}-\mathrm{lb} / \mathrm{in}^{2}\right)\end{array}$ & $\begin{array}{c}J \\
\text { Plastic } \\
\left(\mathrm{in}-\mathrm{lb} / \mathrm{in}^{2}\right) \\
\end{array}$ & $\begin{array}{l}\text { CTOD } \\
\text { (in.) }\end{array}$ & $\begin{array}{l}\text { CTOD } \\
\text { Plastic } \\
\text { (in.) }\end{array}$ \\
\hline 1 & 96 & 0.0034 & 394477 & 0.9999 & 0.0044 & 301203 & 0.9993 & 1543 & -0 & -0 & 1.2289 & -0.0000 & 12 & 0 & -0.0000 & -0.0001 \\
\hline 2 & 105 & 0.0060 & 392108 & 0.9999 & 0.0077 & 302088 & 0.9988 & 2493 & 0 & 0 & 1.2308 & 0.0019 & 33 & 1 & 0.0002 & -0.0001 \\
\hline 3 & 54 & 0.0105 & 391435 & 0.9997 & 0.0132 & 306013 & 0.9995 & 3842 & 4 & 4 & 1.2313 & 0.0024 & 89 & 13 & 0.0007 & 0.0002 \\
\hline 4 & 56 & 0.0155 & 389365 & 0.9997 & 0.0193 & 306064 & 0.9994 & 4740 & 16 & 18 & 1.2329 & 0.0040 & 175 & 60 & 0.0016 & 0.0008 \\
\hline 5 & 64 & 0.0196 & 387678 & 0.9998 & 0.0241 & 305911 & 0.9990 & 5161 & 31 & 35 & 1.2343 & 0.0054 & 251 & 116 & 0.0024 & 0.0014 \\
\hline 6 & 69 & 0.0240 & 387920 & 0.9998 & 0.0292 & 305995 & 0.9988 & 5354 & 51 & 59 & 1.2341 & 0.0052 & 340 & 194 & 0.0033 & 0.0022 \\
\hline 7 & 72 & 0.0279 & 386336 & 0.9997 & 0.0338 & 304760 & 0.9985 & 5510 & 71 & 82 & 1.2353 & 0.0064 & 422 & 267 & 0.0041 & 0.0030 \\
\hline 8 & 74 & 0.0318 & 384723 & 0.9998 & 0.0384 & 304547 & 0.9988 & 5615 & 91 & 105 & 1.2366 & 0.0077 & 506 & 344 & 0.0050 & 0.0038 \\
\hline 9 & 72 & 0.0360 & 383938 & 0.9999 & 0.0432 & 302268 & 0.9983 & 5717 & 113 & 131 & 1.2373 & 0.0083 & 595 & 427 & 0.0058 & 0.0046 \\
\hline 10 & 69 & 0.0401 & 380968 & 0.9998 & 0.0481 & 300869 & 0.9977 & 5802 & 135 & 157 & 1.2396 & 0.0107 & 685 & 511 & 0.0068 & 0.0055 \\
\hline 11 & 70 & 0.0449 & 380737 & 0.9999 & 0.0536 & 299984 & 0.9972 & 5883 & 162 & 188 & 1.2398 & 0.0109 & 790 & 612 & 0.0078 & 0.0065 \\
\hline 12 & 75 & 0.0499 & 377087 & 0.9999 & 0.0593 & 299706 & 0.9979 & 5909 & 191 & 221 & 1.2428 & 0.0138 & 903 & 718 & 0.0089 & 0.0076 \\
\hline 13 & 68 & 0.0550 & 374376 & 0.9998 & 0.0654 & 295361 & 0.9968 & 6009 & 219 & 255 & 1.2450 & 0.0160 & 1019 & 828 & 0.0100 & 0.0086 \\
\hline 14 & 72 & 0.0606 & 371361 & 0.9998 & 0.0717 & 290860 & 0.9957 & 6018 & 252 & 292 & 1.2474 & 0.0185 & 1143 & 948 & 0.0113 & 0.0099 \\
\hline 15 & 68 & 0.0650 & 367546 & 0.9999 & 0.0767 & 287113 & 0.9938 & 6052 & 278 & 320 & 1.2506 & 0.0216 & 1236 & 1037 & 0.0123 & 0.0108 \\
\hline 16 & 66 & 0.0698 & 364180 & 0.9998 & 0.0822 & 285244 & 0.9930 & 6072 & 306 & 351 & 1.2533 & 0.0244 & 1341 & 1139 & 0.0134 & 0.0119 \\
\hline 17 & 69 & 0.0751 & 361683 & 0.9999 & 0.0883 & 284317 & 0.9946 & 6083 & 337 & 387 & 1.2554 & 0.0265 & 1462 & 1257 & 0.0145 & 0.0131 \\
\hline 18 & 70 & 0.0799 & 357171 & 0.9998 & 0.0937 & 283178 & 0.9940 & 6067 & 366 & 421 & 1.2592 & 0.0303 & 1569 & 1362 & 0.0157 & 0.0142 \\
\hline 19 & 70 & 0.0850 & 352033 & 0.9999 & 0.0996 & 280022 & 0.9934 & 6072 & 397 & 456 & 1.2635 & 0.0346 & 1685 & 1474 & 0.0169 & 0.0154 \\
\hline 20 & 66 & 0.0899 & 348030 & 0.9999 & 0.1052 & 274448 & 0.9917 & 6048 & 426 & 490 & 1.2669 & 0.0380 & 1793 & 1580 & 0.0180 & 0.0165 \\
\hline 21 & 72 & 0.09 .50 & 342936 & 0.9999 & 0.1109 & 271567 & 0.9926 & 6021 & 456 & 522 & 1.2713 & 0.0424 & 1896 & 1682 & 0.0193 & 0.0177 \\
\hline 22 & 68 & 0.1000 & 338156 & 0.9998 & 0.1165 & 267540 & 0.9910 & 5967 & 486 & 556 & 1.2755 & 0.0466 & 2003 & 1789 & 0.0205 & 0.0189 \\
\hline 23 & 70 & 0.1049 & 334044 & 0.9998 & 0.1219 & 264949 & 0.9913 & 5914 & 515 & 588 & 1.2791 & 0.0502 & 2103 & 1890 & 0.0217 & 0.0201 \\
\hline 24 & 72 & 0.1102 & 328238 & 0.9999 & 0.1277 & 260021 & 0.9910 & 5901 & 545 & 622 & 1.2843 & 0.0553 & 2210 & 1993 & 0.0230 & 0.0214 \\
\hline 25 & 71 & 0.1150 & 323854 & 0.9998 & 0.1330 & 258413 & 0.9904 & 5828 & 573 & 652 & 1.2882 & 0.0593 & 2303 & 2089 & 0.0242 & 0.0226 \\
\hline 26 & 72 & 0.1199 & 316724 & 0.9998 & 0.1384 & 255013 & 0.9924 & 5695 & 603 & 686 & 1.2947 & 0.0657 & 2401 & 2189 & 0.0255 & 0.0240 \\
\hline 27 & 75 & 0.1261 & 305566 & 0.9997 & 0.1452 & 247223 & 0.9934 & 5629 & 637 & 724 & 1.3050 & 0.0761 & 2507 & 2291 & 0.0272 & 0.0257 \\
\hline 28 & 75 & 0.1308 & 297764 & 0.9998 & 0.1503 & 243065 & 0.9920 & 5559 & 661 & 751 & 1.3124 & 0.0835 & 2579 & 2362 & 0.0285 & 0.0269 \\
\hline 29 & 79 & 0.1370 & 291976 & 0.9999 & 0.1570 & 238255 & 0.9923 & 5520 & 694 & 787 & 1.3180 & 0.0890 & 2694 & 2475 & 0.0301 & 0.0285 \\
\hline 30 & 72 & 0.1430 & 287927 & 0.9998 & 0.1635 & 234047 & 0.9901 & 5475 & 726 & 822 & 1.3219 & 0.0930 & 2810 & 2589 & 0.0316 & 0.0300 \\
\hline 31 & 69 & 0.1490 & 281913 & 0.9998 & 0.1702 & 229327 & 0.9916 & 5438 & 758 & 857 & 1.3278 & 0.0989 & 2916 & 2694 & 0.0332 & 0.0316 \\
\hline 32 & 74 & 0.1551 & 275754 & 0.9997 & 0.1767 & 225044 & 0.9922 & 5335 & 792 & 892 & 1.3340 & 0.1051 & 3021 & 2801 & 0.0349 & 0.0333 \\
\hline 33 & 70 & 0.1619 & 270773 & 0.9997 & 0.1840 & 220097 & 0.9895 & 5267 & 827 & 931 & 1.3390 & 0.1101 & 3143 & 2923 & 0.0367 & 0.0351 \\
\hline 34 & 73 & 0.1689 & 264029 & 0.9997 & 0.1915 & 214313 & 0.9879 & 5167 & 864 & 970 & 1.3460 & 0.1171 & 3263 & 3043 & 0.0387 & 0.0372 \\
\hline 35 & 72 & 0.1759 & 256456 & 0.9995 & 0.1989 & 205626 & 0.9873 & 5053 & 900 & 1008 & 1.3539 & 0.1250 & 3367 & 3149 & 0.0407 & 0.0392 \\
\hline 36 & 76 & 0.1831 & 247589 & 0.9994 & 0.2065 & 200744 & 0.9869 & 4919 & 936 & 1045 & 1.3634 & 0.1345 & 3458 & 3243 & 0.0429 & 0.0414 \\
\hline 37 & 75 & 0.1901 & 237880 & 0.9993 & 0.2137 & 195575 & 0.9878 & 4737 & 970 & 1081 & 1.3741 & 0.1452 & 3543 & 3332 & 0.0451 & 0.0436 \\
\hline 38 & 79 & 0.1970 & 229057 & 0.9992 & 0.2209 & 184251 & 0.9857 & 4612 & 1002 & 1115 & 1.3840 & 0.1551 & 3624 & 3415 & 0.0473 & 0.0457 \\
\hline 39 & 70 & 0.2042 & 219633 & 0.9990 & 0.2285 & 179705 & 0.9917 & 4481 & 1034 & 1147 & 1.3949 & 0.1660 & 3691 & 3482 & 0.0496 & 0.0481 \\
\hline
\end{tabular}




\begin{tabular}{|c|c|c|c|c|c|c|c|c|c|c|c|c|c|c|c|c|}
\hline $\begin{array}{l}\text { Unload } \\
\text { No. }\end{array}$ & $\begin{array}{c}\text { No. of } \\
\text { Data } \\
\text { Points } \\
\end{array}$ & $\begin{array}{l}\text { COD } \\
\text { (in.) }\end{array}$ & $\begin{array}{l}\text { COD } \\
\text { Slope } \\
\text { (lb/in) }\end{array}$ & $\begin{array}{l}\text { COD } \\
\text { Corr. }\end{array}$ & $\begin{array}{c}\text { Loadline } \\
\text { Disp. } \\
\text { (in.) }\end{array}$ & $\begin{array}{c}\text { Loadline } \\
\text { Slope } \\
\text { (lb/in) }\end{array}$ & $\begin{array}{l}\text { Loadline } \\
\text { Corr. }\end{array}$ & $\begin{array}{l}\text { Load } \\
\text { (lb.) }\end{array}$ & $\begin{array}{l}\text { COD } \\
\text { Area } \\
(\text { in }-1 b)\end{array}$ & $\begin{array}{c}\mathrm{LL} \\
\text { Area } \\
\text { (in-lb) }\end{array}$ & $\begin{array}{c}\text { Crack } \\
\text { Length } \\
\text { (in.) }\end{array}$ & $\begin{array}{c}\text { Crack } \\
\text { Extension } \\
\text { (in.) }\end{array}$ & $\begin{array}{c}\mathrm{J} \\
\left(\mathrm{in}-\mathrm{lb} / \mathrm{in}^{2}\right)\end{array}$ & $\begin{array}{c}J \\
\text { Plastic } \\
\left(\text { in }-\mathrm{lb} / \mathrm{in}^{2}\right)\end{array}$ & $\begin{array}{c}\text { CTOD } \\
\text { (in.) }\end{array}$ & $\begin{array}{l}\text { CTOD } \\
\text { Plastic } \\
\text { (in.) }\end{array}$ \\
\hline 40 & 73 & 0.2109 & 213055 & 0.9989 & 0.2355 & 171910 & 0.9892 & 4366 & 1063 & 1179 & 1.4027 & 0.1738 & 3773 & 3566 & 0.0516 & 0.0501 \\
\hline 41 & 74 & 0.2180 & 206351 & 0.9991 & 0.2430 & 166640 & 0.9885 & 4287 & 1093 & 1209 & 1.4108 & 0.1819 & 3850 & 3643 & 0.0538 & 0.0523 \\
\hline 42 & 74 & 0.2251 & 199164 & 0.9990 & 0.2504 & 161142 & 0.9894 & 4181 & 1123 & 1240 & 1.4197 & 0.1908 & 3926 & 3719 & 0.0561 & 0.0546 \\
\hline 43 & 78 & 0.2312 & 192718 & 0.9989 & 0.2566 & 155444 & 0.9891 & 4056 & 1147 & 1265 & 1.4279 & 0.1990 & 3978 & 3776 & 0.0580 & 0.0566 \\
\hline
\end{tabular}




\begin{tabular}{|c|c|c|c|c|c|c|c|c|c|c|c|c|c|c|c|c|}
\hline $\begin{array}{c}\text { Unload } \\
\text { No. }\end{array}$ & $\begin{array}{c}\text { No. of } \\
\text { Data } \\
\text { Points }\end{array}$ & $\begin{array}{l}\text { COD } \\
\text { (in.) }\end{array}$ & $\begin{array}{l}\text { COD } \\
\text { Slope } \\
\text { (lb/in) }\end{array}$ & $\begin{array}{l}\text { COD } \\
\text { Corr. }\end{array}$ & $\begin{array}{l}\text { Loadline } \\
\text { Disp. } \\
\text { (iin.) }\end{array}$ & $\begin{array}{c}\text { Loadline } \\
\text { Slope } \\
\text { (lb/in) }\end{array}$ & $\begin{array}{c}\text { Loadline } \\
\text { Corr. }\end{array}$ & $\begin{array}{l}\text { Load } \\
\text { (lb.) }\end{array}$ & $\begin{array}{l}\text { COD } \\
\text { Area } \\
\text { (in-lb) }\end{array}$ & $\begin{array}{c}\text { LL } \\
\text { Area }_{\text {pl }} \\
(\text { in-lb) }\end{array}$ & $\begin{array}{c}\text { Crack } \\
\text { Length } \\
\text { (in.) } \\
\end{array}$ & $\begin{array}{c}\text { Crack } \\
\text { Extension } \\
\text { (in.) }\end{array}$ & $\begin{array}{c}J \\
\left(\mathrm{in}-\mathrm{lb} / \mathrm{in}^{2}\right)\end{array}$ & $\begin{array}{c}\text { J } \\
\text { Plastic } \\
\left(\mathrm{in}-\mathrm{b} / \mathrm{in}^{2}\right)\end{array}$ & $\begin{array}{l}\text { CTOD } \\
\text { (in.) }\end{array}$ & $\begin{array}{c}\text { CTOD } \\
\text { Plastic } \\
\text { (in.) } \\
\end{array}$ \\
\hline 1 & 69 & 0.0033 & 392732 & 0.9999 & 0.0045 & 288761 & 0.9986 & 1562 & -0 & -0 & 1.2303 & 0.0000 & 13 & 0 & -0.0001 & -0.0001 \\
\hline 2 & 135 & 0.0048 & 390897 & 0.9999 & 0.0064 & 290842 & 0.9989 & 2119 & 0 & -0 & 1.2317 & 0.0014 & 24 & 1 & 0.0000 & -0.0001 \\
\hline 3 & 90 & 0.0093 & 389181 & 0.9999 & 0.0121 & 295163 & 0.9994 & 3567 & 2 & 2 & 1.2331 & 0.0028 & 72 & 8 & 0.0005 & 0.0000 \\
\hline 4 & 79 & 0.0153 & 386502 & 0.9998 & 0.0195 & 294333 & 0.9991 & 4762 & 15 & 18 & 1.2352 & 0.0049 & 174 & 58 & 0.0015 & 0.0007 \\
\hline 5 & 76 & 0.0177 & 386624 & 0.9998 & 0.0224 & 293951 & 0.9990 & 5021 & 23 & 27 & 1.2351 & 0.0048 & 219 & 89 & 0.0020 & 0.0010 \\
\hline 6 & 73 & 0.0220 & 384642 & 0.9997 & 0.0276 & 293963 & 0.9990 & 5298 & 42 & 49 & 1.2367 & 0.0064 & 307 & 162 & 0.0029 & 0.0018 \\
\hline 7 & 86 & 0.0251 & 383567 & 0.9998 & 0.0313 & 293336 & 0.9985 & 5443 & 56 & 67 & 1.2376 & 0.0073 & 372 & 219 & 0.0035 & 0.0024 \\
\hline 8 & 88 & 0.0279 & 384585 & 0.9998 & 0.0347 & 291927 & 0.9982 & 5559 & 70 & 83 & 1.2367 & 0.0064 & 430 & 272 & 0.0041 & 0.0029 \\
\hline 9 & 89 & 0.0320 & 382975 & 0.9998 & 0.0395 & 291938 & 0.9983 & 5659 & 92 & 108 & 1.2380 & 0.0077 & 519 & 354 & 0.0050 & 0.0038 \\
\hline 10 & 85 & 0.0362 & 382026 & 0.9998 & 0.0446 & 290488 & 0.9979 & 5767 & 114 & 135 & 1.2388 & 0.0085 & 613 & 442 & 0.0058 & 0.0046 \\
\hline 11 & 85 & 0.0399 & 380267 & 0.9996 & 0.0489 & 289815 & 0.9981 & 5794 & 135 & 160 & 1.2402 & 0.0099 & 697 & 522 & 0.0067 & 0.0054 \\
\hline 12 & 86 & 0.0440 & 379361 & 0.9997 & 0.0537 & 289043 & 0.9980 & 5882 & 157 & 186 & 1.2409 & 0.0106 & 789 & 608 & 0.0075 & 0.0062 \\
\hline 13 & 86 & 0.0482 & 377615 & 0.9996 & 0.0587 & 288034 & 0.9980 & 5953 & 181 & 214 & 1.2423 & 0.0120 & 885 & 700 & 0.0085 & 0.0071 \\
\hline 14 & 90 & 0.0520 & 377046 & 0.9997 & 0.0633 & 287093 & 0.9979 & 6011 & 203 & 240 & 1.2428 & 0.0125 & 975 & 785 & 0.0093 & 0.0079 \\
\hline 15 & 87 & 0.0571 & 375150 & 0.9996 & 0.0693 & 285357 & 0.9978 & 6048 & 233 & 275 & 1.2443 & 0.0140 & 1094 & 899 & 0.0104 & 0.0090 \\
\hline 16 & 82 & 0.0620 & 373274 & 0.9995 & 0.0751 & 284756 & 0.9974 & 6084 & 263 & 309 & 1.2459 & 0.0156 & 1208 & 1011 & 0.0115 & 0.0101 \\
\hline 17 & 79 & 0.0670 & 369578 & 0.9995 & 0.0810 & 281289 & 0.9969 & 6095 & 293 & 346 & 1.2489 & 0.0186 & 1327 & 1127 & 0.0127 & 0.0112 \\
\hline 18 & 79 & 0.0709 & 367414 & 0.9996 & 0.0855 & 280093 & 0.9961 & 6107 & 315 & 371 & 1.2507 & 0.0204 & 1412 & 1210 & 0.0135 & 0.0121 \\
\hline 19 & 80 & 0.0753 & 363341 & 0.9996 & 0.0907 & 277179 & 0.9967 & 6153 & 342 & 402 & 1.2540 & 0.0237 & 1514 & 1307 & 0.0145 & 0.0130 \\
\hline 20 & 82 & 0.0798 & 360031 & 0.9996 & 0.0960 & 275380 & 0.9966 & 6148 & 368 & 434 & 1.2568 & 0.0265 & 1618 & 1408 & 0.0156 & 0.0141 \\
\hline 21 & 84 & 0.0851 & 357352 & 0.9997 & 0.1022 & 271504 & 0.9960 & 6183 & 400 & 470 & 1.2590 & 0.0287 & 1741 & 1527 & 0.0168 & 0.0152 \\
\hline 22 & 82 & 0.0900 & 354604 & 0.9996 & 0.1078 & 270387 & 0.9961 & 6158 & 430 & 504 & 1.2614 & 0.0311 & 1851 & 1636 & 0.0179 & 0.0163 \\
\hline 23 & 88 & 0.0951 & 349706 & 0.9995 & 0.1137 & 269285 & 0.9967 & 6167 & 461 & 540 & 1.2655 & 0.0352 & 1968 & 1749 & 0.0191 & 0.0175 \\
\hline 24 & 87 & 0.1000 & 344679 & 0.9995 & 0.1194 & 265602 & 0.9970 & 6161 & 490 & 575 & 1.2698 & 0.0395 & 2078 & 1857 & 0.0203 & 0.0187 \\
\hline 25 & 88 & 0.1050 & 340266 & 0.9996 & 0.1251 & 259903 & 0.9964 & 6139 & 520 & 609 & 1.2737 & 0.0434 & 2188 & 1964 & 0.0215 & 0.0199 \\
\hline 26 & 81 & 0.1101 & 335893 & 0.9994 & 0.1309 & 257480 & 0.9962 & 6094 & 551 & 643 & 1.2775 & 0.0472 & 2295 & 2070 & 0.0227 & 0.0211 \\
\hline 27 & 79 & 0.1151 & 328676 & 0.9994 & 0.1365 & 254070 & 0.9962 & 6023 & 581 & 678 & 1.2839 & 0.0536 & 2398 & 2172 & 0.0240 & 0.0224 \\
\hline 28 & 82 & 0.1200 & 322186 & 0.9993 & 0.1420 & 249479 & 0.9960 & 5934 & 610 & 712 & 1.2897 & 0.0594 & 2499 & 2273 & 0.0253 & 0.0237 \\
\hline 29 & 84 & 0.1251 & 315410 & 0.9995 & 0.1479 & 244875 & 0.9955 & 5927 & 639 & 744 & 1.2959 & 0.0656 & 2596 & 2367 & 0.0266 & 0.0250 \\
\hline 30 & 86 & 0.1301 & 307588 & 0.9994 & 0.1534 & 239041 & 0.9936 & 5844 & 667 & 776 & 1.3031 & 0.0728 & 2686 & 2456 & 0.0280 & 0.0263 \\
\hline 31 & 88 & 0.1350 & 302272 & 0.9994 & 0.1588 & 235390 & 0.9933 & 5778 & 695 & 807 & 1.3081 & 0.0778 & 2778 & 2547 & 0.0292 & 0.0276 \\
\hline 32 & 84 & 0.1400 & 295173 & 0.9994 & 0.1646 & 230294 & 0.9918 & 5730 & 723 & 838 & 1.3149 & 0.0846 & 2870 & 2637 & 0.0306 & 0.0289 \\
\hline 33 & 85 & 0.1451 & 289019 & 0.9994 & 0.1701 & 225523 & 0.9906 & 5644 & 751 & 869 & 1.3208 & 0.0906 & 2958 & 2727 & 0.0320 & 0.0303 \\
\hline 34 & 86 & 0.1511 & 281146 & 0.9993 & 0.1767 & 220635 & 0.9916 & 5527 & 785 & 907 & 1.3286 & 0.0983 & 3064 & 2832 & 0.0337 & 0.0320 \\
\hline 35 & 87 & 0.1571 & 275519 & 0.9993 & 0.1832 & 216564 & 0.9906 & 5439 & 817 & 943 & 1.3342 & 0.1039 & 3173 & 2943 & 0.0353 & 0.0336 \\
\hline 36 & 85 & 0.1640 & 267148 & 0.9992 & 0.1909 & 210967 & 0.9915 & 5352 & 854 & 984 & 1.3428 & 0.1125 & 3289 & 3059 & 0.0372 & 0.0356 \\
\hline 37 & 90 & 0.1711 & 257909 & 0.9991 & 0.1986 & 205159 & 0.9939 & 5196 & 892 & 1025 & 1.3524 & 0.1221 & 3399 & 3171 & 0.0394 & 0.0377 \\
\hline 38 & 83 & 0.1782 & 245705 & 0.9991 & 0.2063 & 196348 & 0.9937 & 5028 & 929 & 1066 & 1.3655 & 0.1352 & 3489 & 3262 & 0.0416 & 0.0400 \\
\hline 39 & 84 & 0.1859 & 238285 & 0.9991 & 0.2146 & 190557 & 0.9930 & 4894 & 965 & 1105 & 1.3736 & 0.1433 & 3600 & 3376 & 0.0438 & 0.0422 \\
\hline
\end{tabular}




\begin{tabular}{|c|c|c|c|c|c|c|c|c|c|c|c|c|c|c|c|c|}
\hline $\begin{array}{c}\text { Unload } \\
\text { No. }\end{array}$ & $\begin{array}{c}\text { No. of } \\
\text { Data } \\
\text { Points }\end{array}$ & $\begin{array}{l}\text { COD } \\
\text { (in.) }\end{array}$ & $\begin{array}{l}\text { COD } \\
\text { Slope } \\
\text { (lb/in) }\end{array}$ & $\begin{array}{l}\text { COD } \\
\text { Corr. }\end{array}$ & $\begin{array}{c}\text { Loadline } \\
\text { Disp. } \\
\text { (in.) }\end{array}$ & $\begin{array}{c}\text { Loadline } \\
\text { Slope } \\
\text { (lb/in) }\end{array}$ & $\begin{array}{l}\text { Loadline } \\
\text { Corr. }\end{array}$ & $\begin{array}{l}\text { Load } \\
\text { (lb.) }\end{array}$ & $\begin{array}{c}\text { COD } \\
\text { Area } \\
(\text { in }-\mathrm{lb})\end{array}$ & $\begin{array}{c}\text { LL } \\
\text { Area } \\
(\text { in-lb) }\end{array}$ & $\begin{array}{c}\text { Crack } \\
\text { Length } \\
\text { (in.) }\end{array}$ & $\begin{array}{c}\text { Crack } \\
\text { Extension } \\
\text { (in.) }\end{array}$ & $\begin{array}{c}J \\
\left(\mathrm{in}-\mathrm{lb} / \mathrm{in}^{2}\right)\end{array}$ & $\begin{array}{c}\mathrm{J} \\
\text { Plastic } \\
\left(\mathrm{in}-\mathrm{lb} / \mathrm{in}^{2}\right)\end{array}$ & $\begin{array}{l}\text { CTOD } \\
\text { (in.) }\end{array}$ & $\begin{array}{c}\text { CIOD } \\
\text { Plastic } \\
\text { (in.) }\end{array}$ \\
\hline 40 & 88 & 0.1930 & 227126 & 0.9987 & 0.2222 & 182905 & 0.9936 & 4717 & 1000 & 1143 & 1.3862 & 0.1559 & 3678 & 3457 & 0.0462 & 0.0446 \\
\hline 41 & 90 & 0.1997 & 217857 & 0.9988 & 0.2293 & 174912 & 0.9903 & 4587 & 1030 & 1175 & 1.3970 & 0.1667 & 3745 & 3525 & 0.0483 & 0.0467 \\
\hline 42 & 93 & 0.2071 & 209383 & 0.9987 & 0.2372 & 168259 & 0.9883 & 4480 & 1062 & 1209 & 1.4072 & 0.1769 & 3826 & 3604 & 0.0506 & 0.0490 \\
\hline 43 & 96 & 0.2148 & 202308 & 0.9989 & 0.2453 & 162662 & 0.9877 & 4382 & 1095 & 1243 & 1.4158 & 0.1855 & 3916 & 3695 & 0.0529 & 0.0513 \\
\hline 44 & 101 & 0.2227 & 196033 & 0.9987 & 0.2536 & 159577 & 0.9896 & 4257 & 1129 & 1279 & 1.4237 & 0.1934 & 4016 & 3798 & 0.0553 & 0.0538 \\
\hline
\end{tabular}




\begin{tabular}{|c|c|c|c|c|c|c|c|c|c|c|c|c|c|c|c|c|}
\hline $\begin{array}{l}\text { Unload } \\
\text { No. }\end{array}$ & $\begin{array}{c}\text { No. of } \\
\text { Data } \\
\text { Points }\end{array}$ & $\begin{array}{l}\text { COD } \\
\text { (in.) }\end{array}$ & $\begin{array}{l}\text { COD } \\
\text { Slope } \\
(\text { lb/in) }\end{array}$ & $\begin{array}{l}\text { COD } \\
\text { Corr. }\end{array}$ & $\begin{array}{c}\text { Loadline } \\
\text { Disp. } \\
\text { (in.) }\end{array}$ & $\begin{array}{c}\text { Loadline } \\
\text { Slope } \\
\text { (lb/in) }\end{array}$ & $\begin{array}{c}\text { Loadline } \\
\text { Corr. }\end{array}$ & $\begin{array}{l}\text { Load } \\
\text { (lb.) }\end{array}$ & $\begin{array}{c}\text { C.OD } \\
\text { Area } \\
\text { (in-lb) }\end{array}$ & $\begin{array}{c}\text { LL } \\
\text { Areabl } \\
\text { (in-lb) }\end{array}$ & $\begin{array}{l}\text { Crack } \\
\text { Length } \\
\text { (in.) } \\
\end{array}$ & $\begin{array}{c}\text { Crack } \\
\text { Extension } \\
\text { (in.) } \\
\end{array}$ & $\begin{array}{c}J \\
\left(\mathrm{in}-\mathrm{lb} / \mathrm{in}^{2}\right)\end{array}$ & 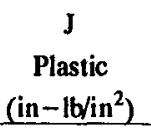 & $\begin{array}{l}\text { CIOD } \\
\text { (in.) }\end{array}$ & $\begin{array}{c}\text { CTOD } \\
\text { Plastic } \\
\text { (in.) } \\
\end{array}$ \\
\hline 1 & 54 & 0.0035 & 386475 & 0.9996 & 0.0048 & 285689 & 0.9985 & 1538 & -0 & -0 & 1.2352 & -0.0000 & 13 & 0 & -0.0000 & -0.0001 \\
\hline 2 & 98 & 0.0050 & 384133 & 0.9999 & 0.0067 & 286057 & 0.9985 & 2091 & 0 & -0 & 1.2371 & 0.0019 & 23 & 0 & 0.0001 & -0.0001 \\
\hline 3 & 108 & 0.0072 & 383317 & 0.9999 & 0.0096 & 284526 & 0.9981 & 2859 & 1 & 0 & 1.2378 & 0.0025 & 45 & 2 & 0.0003 & -0.0000 \\
\hline 4 & 64 & 0.0097 & 383113 & 0.9998 & 0.0127 & 290132 & 0.9988 & 3619 & 2 & 2 & 1.2379 & 0.0027 & 75 & 7 & 0.0006 & 0.0001 \\
\hline 5 & 77 & 0.0136 & 381501 & 0.9998 & 0.0175 & 288783 & 0.9984 & 4470 & 9 & 10 & 1.2392 & 0.0040 & 139 & 35 & 0.0012 & 0.0004 \\
\hline 6 & 72 & 0.0173 & 380884 & 0.9998 & 0.0220 & 288220 & 0.9981 & 5001 & 20 & 23 & 1.2397 & 0.0045 & 207 & 76 & 0.0018 & 0.0009 \\
\hline 7 & 71 & 0.0204 & 380609 & 0.9998 & 0.0258 & 288474 & 0.9981 & 5279 & 32 & 37 & 1.2399 & 0.0047 & 268 & 124 & 0.0025 & 0.0014 \\
\hline 8 & 74 & 0.0248 & 380883 & 0.9998 & 0.0310 & 288735 & 0.9982 & 5492 & 53 & 62 & 1.2397 & 0.0045 & 362 & 205 & 0.0034 & 0.0022 \\
\hline 9 & 59 & 0.0290 & 378904 & 0.9997 & 0.0361 & 287746 & 0.9978 & 5650 & 74 & 87 & 1.2413 & 0.0061 & 454 & 287 & 0.0043 & 0.0031 \\
\hline 10 & 58 & 0.0331 & 378566 & 0.9997 & 0.0409 & 286120 & 0.9978 & 5771 & 96 & 112 & 1.2416 & 0.0063 & 543 & 369 & 0.0051 & 0.0039 \\
\hline 11 & 67 & 0.0370 & 379153 & 0.9997 & 0.0456 & 284365 & 0.9968 & 5864 & 117 & 137 & 1.2411 & 0.0059 & 630 & 451 & 0.0059 & 0.0047 \\
\hline 12 & 68 & 0.0411 & 377685 & 0.9997 & 0.0503 & 284559 & 0.9972 & 5917 & 141 & 163 & 1.2423 & 0.0070 & 722 & 538 & 0.0068 & 0.0055 \\
\hline 13 & 69 & 0.0451 & 377178 & 0.9998 & 0.0551 & 284089 & 0.9971 & 5992 & 164 & 191 & 1.2427 & 0.0075 & 816 & 627 & 0.0077 & 0.0063 \\
\hline 14 & 67 & 0.0492 & 377088 & 0.9997 & 0.0599 & 281485 & 0.9968 & 6070 & 187 & 218 & 1.2428 & 0.0075 & 911 & 718 & 0.0086 & 0.0072 \\
\hline 15 & 71 & 0.0548 & 373573 & 0.9997 & 0.0663 & 281481 & 0.9965 & 6121 & 221 & 256 & 1.2456 & 0.0104 & 1039 & 840 & 0.0098 & 0.0084 \\
\hline 16 & 83 & 0.0599 & 371791 & 0.9996 & 0.0724 & 280454 & 0.9974 & 6193 & 250 & 292 & 1.2471 & 0.0118 & 1162 & 957 & 0.0109 & 0.0094 \\
\hline 17 & 65 & 0.0655 & 369804 & 0.9997 & 0.0789 & 276788 & 0.9955 & 6244 & 284 & 331 & 1.2487 & 0.0135 & 1294 & 1085 & 0.0121 & 0.0106 \\
\hline 18 & 68 & 0.0699 & 366531 & 0.9998 & 0.0841 & 274671 & 0.9957 & 6280 & 311 & 361 & 1.2514 & 0.0162 & 1393 & 1180 & 0.0131 & 0.0116 \\
\hline 19 & 68 & 0.0750 & 364155 & 0.9997 & 0.0899 & 273122 & 0.9952 & 6271 & 342 & 397 & 1.2534 & 0.0181 & 1513 & 1297 & 0.0142 & 0.0127 \\
\hline 20 & 67 & 0.0798 & 361063 & 0.9997 & 0.0955 & 270415 & 0.9954 & 6275 & 372 & 432 & 1.2559 & 0.0207 & 1628 & 1409 & 0.0153 & 0.0138 \\
\hline 21 & 68 & 0.0850 & 356047 & 0.9997 & 0.1014 & 267958 & 0.9948 & 6268 & 404 & 468 & 1.2601 & 0.0249 & 1746 & 1524 & 0.0166 & 0.0150 \\
\hline 22 & 70 & 0.0900 & 351829 & 0.9997 & 0.1071 & 265634 & 0.9947 & 6266 & 434 & 503 & 1.2637 & 0.0285 & 1859 & 1635 & 0.0177 & 0.0161 \\
\hline 23 & 71 & 0.0951 & 347522 & 0.9997 & 0.1130 & 261325 & 0.9944 & 6254 & 465 & 539 & 1.2674 & 0.0321 & 1974 & 1748 & 0.0189 & 0.0172 \\
\hline 24 & 69 & 0.1001 & 342563 & 0.9995 & 0.1186 & 259018 & 0.9938 & 6192 & 497 & 573 & 1.2717 & 0.0364 & 2083 & 1856 & 0.0201 & 0.0185 \\
\hline 25 & 71 & 0.1050 & 338437 & 0.9996 & 0.1243 & 255890 & 0.9937 & 6182 & 526 & 608 & 1.2752 & 0.0400 & 2194 & 1965 & 0.0212 & 0.0196 \\
\hline 26 & 71 & 0.1100 & 334198 & 0.9996 & 0.1299 & 253088 & 0.9943 & 6176 & 556 & 641 & 1.2790 & 0.0437 & 2303 & 2071 & 0.0224 & 0.0208 \\
\hline 27 & 71 & 0.1150 & 330063 & 0.9997 & 0.1357 & 250339 & 0.9933 & 6176 & 586 & 676 & 1.2826 & 0.0474 & 2414 & 2179 & 0.0236 & 0.0219 \\
\hline 28 & 70 & 0.1200 & 324549 & 0.9996 & 0.1411 & 243206 & 0.9909 & 6083 & 617 & 710 & 1.2876 & 0.0523 & 2519 & 2285 & 0.0249 & 0.0232 \\
\hline 29 & 72 & 0.1250 & 318663 & 0.9996 & 0.1468 & 241228 & 0.9900 & 6074 & 646 & 741 & 1.2929 & 0.0577 & 2614 & 2375 & 0.0262 & 0.0244 \\
\hline 30 & 75 & 0.1300 & 313966 & 0.9996 & 0.1524 & 240508 & 0.9922 & 6046 & 675 & 775 & 1.2972 & 0.0620 & 2722 & 2480 & 0.0274 & 0.0257 \\
\hline 31 & 77 & 0.1360 & 309444 & 0.9997 & 0.1591 & 234495 & 0.9915 & 6007 & 710 & 816 & 1.3014 & 0.0662 & 2853 & 2612 & 0.0289 & 0.0271 \\
\hline 32 & 77 & 0.1420 & 302219 & 0.9997 & 0.1658 & 230121 & 0.9891 & 5922 & 747 & 855 & 1.3082 & 0.0729 & 2966 & 2725 & 0.0305 & 0.0288 \\
\hline 33 & 80 & 0.1481 & 296300 & 0.9995 & 0.1725 & 226387 & 0.9892 & 5866 & 781 & 893 & 1.3138 & 0.0786 & 3084 & 2841 & 0.0321 & 0.0303 \\
\hline 34 & 80 & 0.1541 & 290197 & 0.9996 & 0.1792 & 220881 & 0.9867 & 5794 & 816 & 932 & 1.3197 & 0.0845 & 3202 & 2958 & 0.0337 & 0.0319 \\
\hline 35 & 80 & 0.1600 & 284044 & 0.9995 & 0.1857 & 214477 & 0.9819 & 5715 & 849 & 968 & 1.3257 & 0.0905 & 3307 & 3064 & 0.0352 & 0.0335 \\
\hline 36 & 82 & 0.1658 & 274118 & 0.9994 & 0.1919 & 209620 & 0.9852 & 5545 & 883 & 1003 & 1.3356 & 0.1004 & 3389 & 3149 & 0.0370 & 0.0353 \\
\hline 37 & 66 & 0.1739 & 262876 & 0.9992 & 0.2006 & 203602 & 0.9859 & 5386 & 928 & 1053 & 1.3472 & 0.1119 & 3520 & 3279 & 0.0394 & 0.0377 \\
\hline 38 & 61 & 0.1810 & 256585 & 0.9995 & 0.2084 & 195482 & 0.9821 & 5330 & 962 & 1092 & 1.3538 & 0.1185 & 3638 & 3397 & 0.0413 & 0.0395 \\
\hline 39 & 63 & 0.1880 & 251766 & 0.9994 & 0.2160 & 193142 & 0.9822 & 5275 & 999 & 1129 & 1.3589 & 0.1237 & 3754 & 3511 & 0.0432 & 0.0414 \\
\hline
\end{tabular}




\begin{tabular}{|c|c|c|c|c|c|c|c|c|c|c|c|c|c|c|c|c|}
\hline $\begin{array}{c}\text { Unload } \\
\text { No. }\end{array}$ & $\begin{array}{c}\text { No. of } \\
\text { Data } \\
\text { Points }\end{array}$ & $\begin{array}{l}\text { COD } \\
\text { (in.) }\end{array}$ & $\begin{array}{l}\text { COD } \\
\text { Slope } \\
\text { (lb/in) }\end{array}$ & $\begin{array}{l}\text { COD } \\
\text { Corr. }\end{array}$ & $\begin{array}{c}\text { Loadline } \\
\text { Disp. } \\
\text { (in.) }\end{array}$ & $\begin{array}{c}\text { Loadline } \\
\text { Slope } \\
\text { (lb/in) }\end{array}$ & $\begin{array}{c}\text { Loadline } \\
\text { Corr. }\end{array}$ & $\begin{array}{l}\text { Load } \\
\text { (lb.) }\end{array}$ & $\begin{array}{l}\text { COD } \\
\text { Areab! } \\
\text { (in-lb) }\end{array}$ & $\begin{array}{c}\mathrm{LL} \\
\text { Area } \\
\text { (in-lb) }\end{array}$ & $\begin{array}{c}\text { Crack } \\
\text { Length } \\
\text { (in.) }\end{array}$ & $\begin{array}{c}\text { Crack } \\
\text { Extension } \\
\text { (in.) }\end{array}$ & $\begin{array}{c}J \\
\left.\text { (in-lb/in }{ }^{2}\right)\end{array}$ & $\begin{array}{c}\mathrm{J} \\
\text { Plastic } \\
\left(\text { in-lb/in }{ }^{2}\right)\end{array}$ & $\begin{array}{l}\text { CTOD } \\
\text { (in.) }\end{array}$ & $\begin{array}{c}\text { CTOD } \\
\text { Plastic } \\
\text { (in.) }\end{array}$ \\
\hline 40 & 66 & 0.1958 & 246012 & 0.9993 & 0.2245 & 188588 & 0.9818 & 5209 & 1039 & 1174 & 1.3651 & 0.1299 & 3896 & 3652 & 0.0453 & 0.0436 \\
\hline 41 & 64 & 0.2040 & 237944 & 0.9993 & 0.2334 & 182157 & 0.9759 & 5085 & 1082 & 1220 & 1.3740 & 0.1388 & 4026 & 3784 & 0.0478 & 0.0461 \\
\hline 42 & 68 & 0.2111 & 229680 & 0.9992 & 0.2410 & 175404 & 0.9756 & 4945 & 1117 & 1258 & 1.3833 & 0.1481 & 4116 & 3876 & 0.0500 & 0.0483 \\
\hline 43 & 73 & 0.2189 & 218756 & 0.9989 & 0.2490 & 168786 & 0.9784 & 4740 & 1156 & 1298 & 1.3960 & 0.1607 & 4192 & 3957 & 0.0526 & 0.0509 \\
\hline
\end{tabular}




\begin{tabular}{|c|c|c|c|c|c|c|c|c|c|c|c|c|c|c|c|c|}
\hline $\begin{array}{c}\text { Unload } \\
\text { No. }\end{array}$ & $\begin{array}{c}\text { No. of } \\
\text { Data } \\
\text { Points } \\
\end{array}$ & $\begin{array}{l}\text { COD } \\
\text { (iii.) }\end{array}$ & $\begin{array}{l}\text { COD } \\
\text { Slope } \\
\text { (lb/in) }\end{array}$ & $\begin{array}{l}\text { COD } \\
\text { Corr. }\end{array}$ & $\begin{array}{c}\text { Loadline } \\
\text { Disp. } \\
\text { (in.) }\end{array}$ & $\begin{array}{c}\text { Loadline } \\
\text { Slope } \\
\text { (lb/in) }\end{array}$ & $\begin{array}{c}\text { Loadline } \\
\text { Corr. }\end{array}$ & $\begin{array}{l}\text { Load } \\
\text { (lb.) }\end{array}$ & $\begin{array}{l}\text { COD } \\
\text { Area } \\
\text { (in-lb) }\end{array}$ & $\begin{array}{c}\text { LL } \\
\text { Area }_{\text {pl }} \\
\text { (in-lb) }\end{array}$ & $\begin{array}{c}\text { Crack } \\
\text { Length } \\
\text { (in.) }\end{array}$ & $\begin{array}{c}\text { Crack } \\
\text { Extension } \\
\text { (in.) } \\
\end{array}$ & $\begin{array}{c}J \\
\left(\mathrm{in}-\mathrm{lb} / \mathrm{in}^{2}\right)\end{array}$ & $\begin{array}{c}J \\
\text { Plastic } \\
\left(\mathrm{in}-\mathrm{lb} / \mathrm{in}^{2}\right)\end{array}$ & $\begin{array}{l}\text { CTOD } \\
\text { (in.) }\end{array}$ & $\begin{array}{c}\text { CTOD } \\
\text { Plastic } \\
\text { (in.) }\end{array}$ \\
\hline 1 & 78 & 0.0012 & 5601390 & 0.9999 & 0.0050 & 1338824 & 0.9996 & 8318 & -6 & -6 & 0.3057 & -0.0043 & 19 & -5 & -0.0010 & -0.0012 \\
\hline 2 & 116 & 0.0026 & 5589843 & 0.9999 & 0.0101 & 1358625 & 0.9995 & 14818 & 9 & 7 & 0.3062 & -0.0038 & 82 & 9 & 0.0005 & -0.0000 \\
\hline 3 & 124 & 0.0054 & 5528845 & 0.9997 & 0.0181 & 1379006 & 0.9997 & 21790 & 38 & 65 & 0.3093 & -0.0007 & 226 & 67 & 0.0022 & 0.0011 \\
\hline 4 & 100 & 0.0080 & 5509548 & 0.9994 & 0.0242 & 1377008 & 0.9997 & 24239 & 88 & 171 & 0.3103 & 0.0003 & 372 & 174 & 0.0040 & 0.0026 \\
\hline 5 & 101 & 0.0101 & 5485111 & 0.9993 & 0.0288 & 1377228 & 0.9997 & 25423 & 135 & 266 & 0.3116 & 0.0016 & 487 & 271 & 0.0054 & 0.0039 \\
\hline 6 & 120 & 0.0123 & 5397428 & 0.9992 & 0.0334 & 1376004 & 0.9998 & 26185 & 188 & 373 & 0.3162 & 0.0062 & 613 & 382 & 0.0070 & 0.0053 \\
\hline 7 & 117 & 0.0130 & 5437822 & 0.9991 & 0.0350 & 1375451 & 0.9998 & 26508 & 204 & 407 & 0.3140 & 0.0040 & 652 & 416 & 0.0074 & 0.0057 \\
\hline 8 & 115 & 0.0145 & 5409795 & 0.9992 & 0.0382 & 1371343 & 0.9997 & 26916 & 243 & 485 & 0.3155 & 0.0055 & 738 & 496 & 0.0085 & 0.0068 \\
\hline 9 & 114 & 0.0162 & 5370063 & 0.9993 & 0.0416 & 1367841 & 0.9997 & 27090 & 290 & 575 & 0.3176 & 0.0076 & 838 & 589 & 0.0098 & 0.0080 \\
\hline 10 & 105 & 0.0181 & 5356431 & 0.9994 & 0.0453 & 1371469 & 0.9997 & 27447 & 338 & 669 & 0.3183 & 0.0083 & 943 & 686 & 0.0110 & 0.0092 \\
\hline 11 & 107 & 0.0200 & 5310725 & 0.9992 & 0.0493 & 1369624 & 0.9997 & 27800 & 390 & 774 & 0.3208 & 0.0108 & 1062 & 797 & 0.0124 & 0.0105 \\
\hline 12 & 97 & 0.0220 & 5319411 & 0.9993 & 0.0533 & 1370473 & 0.9995 & 27986 & 445 & 883 & 0.3203 & 0.0103 & 1180 & 908 & 0.0138 & 0.0119 \\
\hline 13 & 110 & 0.0244 & 5250658 & 0.9991 & 0.0581 & 1367325 & 0.9996 & 28493 & 511 & 1010 & 0.3241 & 0.0141 & 1325 & 1044 & 0.0155 & 0.0135 \\
\hline 14 & 112 & 0.0267 & 5201608 & 0.9988 & 0.0626 & 1366657 & 0.9996 & 28607 & 574 & 1139 & 0.3268 & 0.0168 & 1469 & 1182 & 0.0171 & 0.0151 \\
\hline 15 & 111 & 0.0292 & 5185969 & 0.9989 & 0.0677 & 1363051 & 0.9996 & 28947 & 644 & 1279 & 0.3277 & 0.0177 & 1623 & 1330 & 0.0189 & 0.0168 \\
\hline 16 & 111 & 0.0320 & 5112188 & 0.9989 & 0.0733 & 1360585 & 0.9995 & 29078 & 726 & 1440 & 0.3319 & 0.0219 & 1806 & 1506 & 0.0209 & 0.0188 \\
\hline 17 & 110 & 0.0350 & 5025476 & 0.9988 & 0.0793 & 1356483 & 0.9996 & 29542 & 810 & 1609 & 0.3370 & 0.0270 & 2006 & 1695 & 0.0230 & 0.0208 \\
\hline 18 & 110 & 0.0380 & 5011216 & 0.9988 & 0.0852 & 1351978 & 0.9995 & 29763 & 895 & 1777 & 0.3379 & 0.0279 & 2195 & 1876 & 0.0251 & 0.0228 \\
\hline 19 & 110 & 0.0411 & 4907296 & 0.9986 & 0.0912 & 1349278 & 0.9996 & 29841 & 988 & 1955 & 0.3442 & 0.0342 & 2408 & 2081 & 0.0273 & 0.0250 \\
\hline 20 & 102 & 0.0440 & 4796400 & 0.9986 & 0.0968 & 1342955 & 0.9995 & 30087 & 1072 & 2121 & 0.3511 & 0.0411 & 2617 & 2280 & 0.0294 & 0.0270 \\
\hline 21 & 98 & 0.0457 & 4760767 & 0.9987 & 0.0999 & 1339309 & 0.9994 & 30073 & 1119 & 2212 & 0.3534 & 0.0434 & 2727 & 2386 & 0.0305 & 0.0281 \\
\hline 22 & 97 & 0.0491 & 4645390 & 0.9985 & 0.1063 & 1330674 & 0.9994 & 30287 & 1219 & 2400 & 0.3610 & 0.0510 & 2968 & 2615 & 0.0330 & 0.0305 \\
\hline 23 & 96 & 0.0521 & 4564401 & 0.9987 & 0.1120 & 1321653 & 0.9992 & 30447 & 1307 & 2568 & 0.3665 & 0.0565 & 3181 & 2821 & 0.0351 & 0.0326 \\
\hline 24 & 107 & 0.0551 & 4471934 & 0.9984 & 0.1174 & 1317674 & 0.9994 & 30500 & 1395 & 2730 & 0.3729 & 0.0629 & 3394 & 3025 & 0.0373 & 0.0346 \\
\hline 25 & 95 & 0.0580 & 4427084 & 0.9986 & 0.1229 & 1312311 & 0.9990 & 30515 & 1483 & 2896 & 0.3761 & 0.0661 & 3601 & 3226 & 0.0394 & 0.0367 \\
\hline 26 & 101 & 0.0619 & 4294268 & 0.9986 & 0.1298 & 1304963 & 0.9993 & 30476 & 1602 & 3110 & 0.3859 & 0.0759 & 3895 & 3512 & 0.0423 & 0.0395 \\
\hline 27 & 117 & 0.0661 & 4135068 & 0.9982 & 0.1370 & 1299022 & 0.9997 & 30340 & 1727 & 3334 & 0.3982 & 0.0882 & 4220 & 3828 & 0.0453 & 0.0425 \\
\hline 28 & 94 & 0.0700 & 4025826 & 0.9988 & 0.1436 & 1283575 & 0.9988 & 30307 & 1839 & 3536 & 0.4070 & 0.0970 & 4511 & 4109 & 0.0481 & 0.0452 \\
\hline 29 & 92 & 0.0740 & 3932694 & 0.9987 & 0.1505 & 1269814 & 0.9986 & 30274 & 1954 & 3736 & 0.4148 & 0.1048 & 4800 & 4392 & 0.0509 & 0.0480 \\
\hline 30 & 92 & 0.0780 & 3718386 & 0.9984 & 0.1566 & 1246125 & 0.9986 & 29676 & 2079 & 3933 & 0.4338 & 0.1238 & 5151 & 4737 & 0.0540 & 0.0511 \\
\hline 31 & 90 & 0.0821 & 3535682 & 0.9984 & 0.1630 & 1226804 & 0.9985 & 29370 & 2189 & 4117 & 0.4511 & 0.1411 & 5498 & 5075 & 0.0569 & 0.0539 \\
\hline 32 & 94 & 0.0862 & 3357620 & 0.9982 & 0.1693 & 1203046 & 0.9986 & 28773 & 2305 & 4307 & 0.4692 & 0.1592 & 5870 & 5444 & 0.0600 & 0.0570 \\
\hline 33 & 95 & 0.0901 & 3189491 & 0.9981 & 0.1752 & 1179053 & 0.9987 & 28528 & 2406 & 4470 & 0.4875 & 0.1775 & 6232 & 5795 & 0.0628 & 0.0597 \\
\hline 34 & 88 & 0.0941 & 3026638 & 0.9978 & 0.1807 & 1150153 & 0.9982 & 27726 & 2516 & 4638 & 0.5064 & 0.1964 & 6619 & 6182 & 0.0658 & 0.0627 \\
\hline 35 & 85 & 0.0980 & 2881543 & 0.9985 & 0.1868 & 1127298 & 0.9975 & 27497 & 2617 & 4795 & 0.5243 & 0.2143 & 7016 & 6567 & 0.0687 & 0.0655 \\
\hline
\end{tabular}




\begin{tabular}{|c|c|c|c|c|c|c|c|c|c|c|c|c|c|c|c|c|}
\hline $\begin{array}{l}\text { Unload } \\
\text { No. }\end{array}$ & $\begin{array}{c}\text { No. of } \\
\text { Data } \\
\text { Points } \\
\end{array}$ & $\begin{array}{l}\text { COD } \\
\text { (in.) }\end{array}$ & $\begin{array}{l}\text { COD } \\
\text { Slope } \\
\text { (lb/in) }\end{array}$ & $\begin{array}{l}\text { COD } \\
\text { Corr. }\end{array}$ & $\begin{array}{c}\text { Loadline } \\
\text { Disp. } \\
\text { (in.) }\end{array}$ & $\begin{array}{c}\text { Loadline } \\
\text { Slope } \\
\text { (lb/in) }\end{array}$ & $\begin{array}{c}\text { Loadline } \\
\text { Corr. }\end{array}$ & $\begin{array}{l}\text { Load } \\
\text { (lb.) }\end{array}$ & $\begin{array}{l}\text { COD } \\
\text { Area } \\
\text { (in-lb) }\end{array}$ & $\begin{array}{c}\text { LL } \\
\text { Area } \\
(\text { in-lb) }\end{array}$ & $\begin{array}{c}\text { Crack } \\
\text { Length } \\
\text { (in.) }\end{array}$ & $\begin{array}{c}\text { Crack } \\
\text { Extension } \\
\text { (in.) }\end{array}$ & $\begin{array}{c}J \\
\left(\mathrm{in}-\mathrm{ib} / \mathrm{in}^{2}\right)\end{array}$ & $\begin{array}{c}\mathbf{J} \\
\text { Plastic } \\
\left(\mathrm{in}-\mathrm{lb} / \mathrm{in}^{2}\right)\end{array}$ & $\begin{array}{l}\text { CTOD } \\
\text { (in.) }\end{array}$ & $\begin{array}{c}\text { CTOD } \\
\text { Plastic } \\
\text { (in.) }\end{array}$ \\
\hline 1 & 76 & 0.0011 & 5668447 & 0.9996 & 0.0045 & 1313515 & 0.9997 & 6208 & -3 & -7 & 0.3043 & -0.0057 & 8 & -5 & -0.0006 & -0.0007 \\
\hline 2 & 92 & 0.0022 & 5614829 & 0.9993 & 0.0091 & 1333018 & 0.9997 & 12246 & 4 & 4 & 0.3069 & -0.0031 & 57 & 6 & 0.0004 & 0.0001 \\
\hline 3 & 109 & 0.0041 & 5580488 & 0.9988 & 0.0153 & 1348620 & 0.9997 & 19023 & 15 & 24 & 0.3087 & -0.0013 & 154 & 25 & 0.0014 & 0.0005 \\
\hline 4 & 98 & 0.0067 & 5541349 & 0.9992 & 0.0223 & 1339572 & 0.9998 & 23689 & 53 & 106 & 0.3106 & 0.0006 & 297 & 109 & 0.0031 & 0.0017 \\
\hline 5 & 109 & 0.0086 & 5500213 & 0.9997 & 0.0269 & 1343905 & 1.0000 & 25309 & 93 & 185 & 0.3128 & 0.0028 & 404 & 190 & 0.0044 & 0.0028 \\
\hline 6 & 112 & 0.0106 & $\mathbf{5 4 7 7 1 5 7}$ & 0.9998 & 0.0313 & 1340213 & 0.9999 & 26362 & 139 & 283 & 0.3140 & 0.0040 & 519 & 289 & 0.0057 & 0.0041 \\
\hline 7 & 106 & 0.0125 & 5461503 & 0.9998 & 0.0353 & 1334666 & 0.9999 & 26970 & 188 & 378 & 0.3148 & 0.0048 & 629 & 386 & 0.0071 & 0.0053 \\
\hline 8 & 100 & 0.0152 & 5419377 & 0.9997 & 0.0409 & 1331716 & 0.9999 & 27583 & 259 & 520 & 0.3170 & 0.0070 & 789 & 533 & 0.0090 & 0.0072 \\
\hline 9 & 103 & 0.0175 & 5375484 & 0.9995 & 0.0457 & 1330490 & 0.9999 & 28120 & 320 & 643 & 0.3193 & 0.0093 & 930 & 661 & 0.0106 & 0.0087 \\
\hline 10 & 98 & 0.0196 & 5334672 & 0.9994 & 0.0502 & 1326036 & 0.9999 & 28435 & 379 & 765 & 0.3215 & 0.0115 & 1066 & 788 & 0.0121 & 0.0101 \\
\hline 11 & 98 & 0.0216 & 5300207 & 0.9993 & 0.0545 & 1316509 & 0.9997 & 28834 & 434 & 878 & 0.3234 & 0.0134 & 1193 & 908 & 0.0135 & 0.0115 \\
\hline 12 & 98 & 0.0237 & 5255326 & 0.9994 & 0.0588 & 1316604 & 0.9999 & 29046 & 493 & 997 & 0.3259 & 0.0159 & 1327 & 1034 & 0.0150 & 0.0129 \\
\hline 13 & 110 & 0.0258 & 5191588 & 0.9994 & 0.0632 & 1310962 & 1.0000 & 29310 & 554 & 1121 & 0.3294 & 0.0194 & 1471 & 1169 & 0.0165 & 0.0143 \\
\hline 14 & 105 & 0.0277 & 5148259 & 0.9995 & 0.0671 & 1306238 & 1.0000 & 29597 & 607 & 1229 & 0.3319 & 0.0219 & 1595 & 1286 & 0.0178 & 0.0156 \\
\hline 15 & 106 & 0.0297 & 5080144 & 0.9995 & 0.0711 & 1299417 & 1.0000 & 29762 & 665 & 1345 & 0.3359 & 0.0259 & 1731 & 1415 & 0.0193 & 0.0170 \\
\hline 16 & 104 & 0.0314 & 5030690 & 0.9996 & 0.0746 & 1293529 & 1.0000 & 29935 & 715 & 1444 & 0.3388 & 0.0288 & 1847 & 1526 & 0.0205 & 0.0182 \\
\hline 17 & 101 & 0.0335 & 4986610 & 0.9996 & 0.0786 & 1288344 & 1.0000 & 30047 & 774 & 1561 & 0.3414 & 0.0314 & 1983 & 1656 & 0.0219 & 0.0195 \\
\hline 18 & 104 & 0.0357 & 4936783 & 0.9996 & 0.0832 & 1282631 & 1.0000 & 30355 & 841 & 1693 & 0.3444 & 0.0344 & 2141 & 1804 & 0.0235 & 0.0211 \\
\hline 19 & 99 & 0.0379 & 4892112 & 0.9996 & 0.0875 & 1277361 & 1.0000 & 30446 & 904 & 1818 & 0.3472 & 0.0372 & 2288 & 1945 & 0.0250 & 0.0226 \\
\hline 20 & 98 & 0.0401 & 4837525 & 0.9997 & 0.0919 & 1269324 & 0.9999 & 30681 & 971 & 1948 & 0.3506 & 0.0406 & 2444 & 2095 & 0.0266 & 0.0241 \\
\hline 21 & 102 & 0.0425 & 4784062 & 0.9995 & 0.0965 & 1261918 & 0.9997 & 30810 & 1042 & 2084 & 0.3540 & 0.0440 & 2609 & 2252 & 0.0283 & 0.0257 \\
\hline 22 & 96 & 0.0450 & 4731295 & 0.9996 & 0.1014 & 1259834 & 1.0000 & 30903 & 1118 & 2230 & 0.3574 & 0.0474 & 2783 & 2422 & 0.0301 & 0.0275 \\
\hline 23 & 90 & 0.0475 & 4663114 & 0.9996 & 0.1061 & 1248657 & 0.9999 & 31006 & 1194 & 2375 & 0.3620 & 0.0520 & 2965 & 2596 & 0.0319 & 0.0292 \\
\hline 24 & 95 & 0.0504 & 4558776 & 0.9996 & 0.1115 & 1245016 & 0.9999 & 31010 & 1282 & 2540 & 0.3690 & 0.0590 & 3180 & 2804 & 0.0340 & 0.0313 \\
\hline 25 & 95 & 0.0532 & 4502587 & 0.9996 & 0.1169 & 1228402 & 0.9998 & 31145 & 1367 & 2705 & 0.3730 & 0.0630 & 3388 & 3004 & 0.0359 & 0.0332 \\
\hline 26 & 94 & 0.0562 & 4422675 & 0.9995 & 0.1225 & 1213864 & 0.9999 & 31205 & 1458 & 2871 & 0.3787 & 0.0687 & 3606 & 3214 & 0.0381 & 0.0353 \\
\hline 27 & 92 & 0.0590 & 4301539 & 0.9993 & 0.1277 & 1200281 & 0.9999 & 31212 & 1545 & 3027 & 0.3876 & 0.0776 & 3830 & 3428 & 0.0402 & 0.0373 \\
\hline 28 & 94 & 0.0618 & 4201367 & 0.9994 & 0.1328 & 1190583 & 0.9999 & 31211 & 1627 & 3178 & 0.3952 & 0.0852 & 4047 & 3636 & 0.0422 & 0.0392 \\
\hline 29 & 92 & 0.0651 & 4087879 & 0.9996 & 0.1386 & 1174613 & 0.9999 & 31062 & 1728 & 3359 & 0.4042 & 0.0942 & 4306 & 3891 & 0.0446 & 0.0416 \\
\hline 30 & 92 & 0.0690 & 3823951 & 0.9992 & 0.1446 & 1154260 & 0.9998 & 30305 & 1846 & 3557 & 0.4266 & 0.1166 & 4659 & 4238 & 0.0475 & 0.0445 \\
\hline 31 & 85 & 0.0717 & 3705759 & 0.9993 & 0.1493 & 1131508 & 0.9996 & 30188 & 1918 & 3691 & 0.4373 & 0.1273 & 4890 & 4460 & 0.0494 & 0.0463 \\
\hline 32 & 86 & 0.0751 & 3600312 & 0.9993 & 0.1549 & 1117661 & 0.9995 & 30094 & 2013 & 3849 & 0.4473 & 0.1373 & 5157 & 4718 & 0.0517 & 0.0486 \\
\hline 33 & 86 & 0.0786 & 3453664 & 0.9993 & 0.1607 & 1098954 & 0.9996 & 29691 & 2116 & 4026 & 0.4617 & 0.1517 & 5481 & 5038 & 0.0544 & 0.0512 \\
\hline 34 & 90 & 0.0822 & 3317182 & 0.9995 & 0.1665 & 1080019 & 0.9998 & 29346 & 2218 & 4198 & 0.4760 & 0.1660 & 5811 & 5362 & 0.0570 & 0.0538 \\
\hline 35 & 88 & 0.0859 & 3166411 & 0.9996 & 0.1722 & 1055883 & 0.9997 & 28835 & 2320 & 4366 & 0.4926 & 0.1826 & 6164 & 5713 & 0.0597 & 0.0565 \\
\hline 36 & 86 & 0.0893 & 3002597 & 0.9996 & 0.1772 & 1031192 & 0.9995 & 28160 & 2413 & 4511 & 0.5118 & 0.2018 & 6520 & 6068 & 0.0623 & 0.0590 \\
\hline
\end{tabular}




\begin{tabular}{|c|c|c|c|c|c|c|c|c|c|c|c|c|c|c|c|c|}
\hline $\begin{array}{c}\text { Unload } \\
\text { No. }\end{array}$ & $\begin{array}{c}\text { No. of } \\
\text { Data } \\
\text { Points }\end{array}$ & $\begin{array}{l}\text { COD } \\
\text { (in.) }\end{array}$ & $\begin{array}{l}\text { COD } \\
\text { Slope } \\
\text { (Ib/in) }\end{array}$ & $\begin{array}{l}\text { COD } \\
\text { Corr. }\end{array}$ & $\begin{array}{l}\text { Loadline } \\
\text { Disp. } \\
\text { (in.) }\end{array}$ & $\begin{array}{l}\text { Loadline } \\
\text { Slope } \\
\text { (lb/in) }\end{array}$ & $\begin{array}{l}\text { Loadline } \\
\text { Corr. }\end{array}$ & $\begin{array}{l}\text { Load } \\
\text { (lb.) }\end{array}$ & $\begin{array}{l}\text { COD } \\
\text { Area } \\
(\text { in }-1 b)\end{array}$ & $\begin{array}{c}\text { LL } \\
\text { Areabl } \\
(\text { in-lb) }\end{array}$ & $\begin{array}{c}\text { Crack } \\
\text { Length } \\
\text { (in.) }\end{array}$ & $\begin{array}{c}\text { Crack } \\
\text { Extension } \\
\text { (in.) }\end{array}$ & $\begin{array}{c}J \\
\left(\mathrm{in}-\mathrm{lb} / \mathrm{in}^{2}\right)\end{array}$ & $\begin{array}{c}\mathbf{J} \\
\text { Plastic } \\
\left(\mathrm{in}-\mathrm{lb} / \mathrm{in}^{2}\right) \\
\end{array}$ & $\begin{array}{l}\text { CTOD } \\
\text { (in.) }\end{array}$ & $\begin{array}{l}\text { CTOD } \\
\text { Plastic } \\
\text { (in.) }\end{array}$ \\
\hline 1 & 90 & 0.0009 & 5809567 & 0.9998 & 0.0037 & 1400462 & 1.0000 & 5460 & -2 & -3 & 0.2928 & -0.0032 & 8 & -2 & -0.0005 & -0.0005 \\
\hline 2 & 104 & 0.0017 & 5793068 & 0.9998 & 0.0070 & 1389553 & 1.0000 & 9973 & 2 & 3 & 0.2936 & -0.0024 & 36 & 4 & 0.0002 & 0.0000 \\
\hline 3 & 119 & 0.0030 & 5779673 & 0.9997 & 0.0118 & 1376350 & 1.0000 & 15806 & 7 & 11 & 0.2942 & -0.0018 & 92 & 11 & 0.0008 & 0.0002 \\
\hline 4 & 108 & 0.0047 & 5766104 & 0.9996 & 0.0171 & 1376462 & 1.0000 & 20721 & 23 & 41 & 0.2948 & -0.0012 & 179 & 41 & 0.0018 & 0.0008 \\
\hline 5 & 93 & 0.0081 & 5726208 & 0.9999 & 0.0255 & 1374582 & 0.9999 & 24623 & 85 & 171 & 0.2967 & 0.0007 & 360 & 168 & 0.0041 & 0.0027 \\
\hline 6 & 100 & 0.0106 & 5696771 & 0.9997 & 0.0312 & 1366025 & 0.9999 & 25903 & 144 & 294 & 0.2981 & 0.0021 & 504 & 290 & 0.0059 & 0.0044 \\
\hline 7 & 105 & 0.0130 & 5664016 & 0.9996 & 0.0364 & 1368479 & 1.0000 & 26666 & 204 & 415 & 0.2997 & 0.0037 & 637 & 410 & 0.0076 & 0.0060 \\
\hline 8 & 94 & 0.0152 & 5646861 & 0.9995 & 0.0412 & 1367369 & 1.0000 & 27199 & 261 & 536 & 0.3006 & 0.0046 & 768 & 530 & 0.0092 & 0.0075 \\
\hline 9 & 103 & 0.0180 & 5587673 & 0.9994 & 0.0472 & 1363706 & 1.0000 & 27615 & 337 & 696 & 0.3035 & 0.0075 & 939 & 692 & 0.0112 & 0.0095 \\
\hline 10 & 112 & 0.0195 & 5558580 & 0.9992 & 0.0503 & 1361972 & 1.0000 & 27994 & 374 & 774 & 0.3049 & 0.0089 & 1027 & 771 & 0.0122 & 0.0104 \\
\hline 11 & 98 & 0.0214 & 5546410 & 0.9994 & 0.0545 & 1360863 & 1.0000 & 28223 & 428 & 888 & 0.3055 & 0.0095 & 1146 & 885 & 0.0136 & 0.0117 \\
\hline 12 & 92 & 0.0234 & 5527983 & 0.9995 & 0.0587 & 1358944 & 0.9999 & 28511 & 485 & 1005 & 0.3065 & 0.0105 & 1270 & 1004 & 0.0151 & 0.0131 \\
\hline 13 & 102 & 0.0259 & 5449813 & 0.9994 & 0.0641 & 1355647 & 0.9999 & 28823 & 556 & 1152 & 0.3105 & 0.0145 & 1433 & 1158 & 0.0169 & 0.0149 \\
\hline 14 & 94 & 0.0285 & 5424896 & 0.9993 & 0.0695 & 1351591 & 0.9999 & 29124 & 629 & 1305 & 0.3118 & 0.0158 & 1596 & 1314 & 0.0187 & 0.0167 \\
\hline 15 & 98 & 0.0304 & 5367021 & 0.9994 & 0.0734 & 1348557 & 0.9999 & 29357 & 682 & 1414 & 0.3148 & 0.0188 & 1720 & 1430 & 0.0201 & 0.0180 \\
\hline 16 & 100 & 0.0327 & 5304456 & 0.9994 & 0.0782 & 1344888 & 0.9999 & 29539 & 749 & 1553 & 0.3182 & 0.0222 & 1876 & 1579 & 0.0217 & 0.0196 \\
\hline 17 & 90 & 0.0351 & 5273148 & 0.9995 & 0.0831 & 1343335 & 1.0000 & 29784 & 817 & 1695 & 0.3199 & 0.0239 & 2031 & 1728 & 0.0234 & 0.0212 \\
\hline 18 & 89 & 0.0379 & 5211639 & 0.9995 & 0.0889 & 1338402 & 1.0000 & 30042 & 900 & 1864 & 0.3233 & 0.0273 & 2220 & 1911 & 0.0254 & 0.0232 \\
\hline 19 & 96 & 0.0403 & 5146864 & 0.9993 & 0.0939 & 1332584 & 0.9999 & 30258 & 973 & 2012 & 0.3269 & 0.0309 & 2391 & 2074 & 0.0272 & 0.0249 \\
\hline 20 & 96 & 0.0436 & 5049776 & 0.9994 & 0.1005 & 1326866 & 0.9999 & 30452 & 1071 & 2209 & 0.3325 & 0.0365 & 2622 & 2295 & 0.0296 & 0.0272 \\
\hline 21 & 101 & 0.0468 & 4946480 & 0.9994 & 0.1069 & 1317317 & 0.9999 & 30652 & 1166 & 2398 & 0.3387 & 0.0427 & 2849 & 2513 & 0.0319 & 0.0295 \\
\hline 22 & 94 & 0.0499 & 4872554 & 0.999 .5 & 0.1128 & 1312413 & 0.9999 & 30684 & 1259 & 2579 & 0.3432 & 0.0472 & 3063 & 2721 & 0.0341 & 0.0316 \\
\hline 23 & 105 & 0.0534 & 4693497 & 0.9993 & 0.1193 & 1299496 & 0.9999 & 30676 & 1366 & 2780 & 0.3546 & 0.0586 & 3332 & 2979 & 0.0367 & 0.0342 \\
\hline 24 & 103 & 0.0567 & 4594844 & 0.9994 & 0.1254 & 1290140 & 0.9999 & 30750 & 1460 & 2962 & 0.3612 & 0.0652 & 3565 & 3203 & 0.0390 & 0.0364 \\
\hline 25 & 100 & 0.0597 & 4526351 & 0.9995 & 0.1312 & 1285971 & 0.9999 & 30982 & 1549 & 3133 & 0.3659 & 0.0699 & 3782 & 3411 & 0.0412 & 0.0385 \\
\hline 26 & 98 & 0.0631 & 4398990 & 0.9994 & 0.1374 & 1276346 & 0.9999 & 30833 & 1655 & 3328 & 0.3749 & 0.0789 & 4044 & 3669 & 0.0437 & 0.0410 \\
\hline 27 & 97 & 0.0661 & 4297059 & 0.9995 & 0.1427 & 1262473 & 1.0000 & 30742 & 1743 & 3492 & 0.3823 & 0.0863 & 4272 & 3889 & 0.0459 & 0.0431 \\
\hline 28 & 95 & 0.0696 & 4192172 & 0.9995 & 0.1488 & 1255776 & 1.0000 & 30668 & 1847 & 3676 & 0.3903 & 0.0943 & 4530 & 4139 & 0.0484 & 0.0456 \\
\hline 29 & 102 & 0.0731 & 4060060 & 0.9993 & 0.1550 & 1238966 & 1.0000 & 30511 & 1955 & 3872 & 0.4008 & 0.1048 & 4818 & 4421 & 0.0511 & 0.0482 \\
\hline 30 & 95 & 0.0765 & 3925128 & 0.9994 & 0.1607 & 1222208 & 1.0000 & 30267 & 2054 & 4042 & 0.4120 & 0.1160 & 5088 & 4684 & 0.0536 & 0.0507 \\
\hline 31 & 90 & 0.0798 & 3775994 & 0.9991 & 0.1658 & 1205498 & 0.9997 & 29820 & 2150 & 4200 & 0.4250 & 0.1290 & 5356 & 4950 & 0.0560 & 0.0531 \\
\hline 32 & 90 & 0.0828 & 3630872 & 0.9995 & 0.1706 & 1181587 & 1.0000 & 29627 & 2233 & 4339 & 0.4384 & 0.1424 & 5616 & 5202 & 0.0582 & 0.0553 \\
\hline 33 & 98 & 0.0864 & 3456406 & 0.9991 & 0.1760 & 1159602 & 0.9998 & 29234 & 2335 & 4496 & 0.4554 & 0.1594 & 5930 & 5511 & 0.0610 & 0.0579 \\
\hline 34 & 101 & 0.0890 & 3344877 & 0.9994 & 0.1799 & 1142027 & 1.0000 & 29088 & 2400 & 4602 & 0.4669 & 0.1709 & 6158 & 5728 & 0.0628 & 0.0597 \\
\hline
\end{tabular}




\begin{tabular}{|c|c|c|c|c|c|c|c|c|c|c|c|c|c|c|c|c|}
\hline $\begin{array}{c}\text { Unload } \\
\text { No. }\end{array}$ & $\begin{array}{c}\text { No. of } \\
\text { Data } \\
\text { Points }\end{array}$ & $\begin{array}{l}\text { COD } \\
\text { (in.) }\end{array}$ & $\begin{array}{l}\text { COD } \\
\text { Slope } \\
\text { (lb/in) }\end{array}$ & $\begin{array}{l}\text { COD } \\
\text { Corr. }\end{array}$ & $\begin{array}{l}\text { Loadline } \\
\text { Disp. } \\
\text { (in.) } \\
\end{array}$ & $\begin{array}{l}\text { Loadline } \\
\text { Slope } \\
\text { (lb/in) }\end{array}$ & $\begin{array}{l}\text { Loadline } \\
\text { Corr. }\end{array}$ & $\begin{array}{l}\text { Load } \\
\text { (lb.) }\end{array}$ & $\begin{array}{c}\text { COD } \\
\text { Area } \\
(\text { in }-1 b)\end{array}$ & $\begin{array}{c}\text { LL } \\
\text { Area } \\
(\text { in-lb) }\end{array}$ & $\begin{array}{c}\text { Crack } \\
\text { Length } \\
\text { (in.) }\end{array}$ & $\begin{array}{c}\text { Crack } \\
\text { Extension } \\
\text { (in.) }\end{array}$ & $\begin{array}{c}J \\
\left(i n-l b / i^{2}\right)\end{array}$ & $\begin{array}{c}\mathbf{J} \\
\text { Plastic } \\
\left(\text { in-lb/inn }{ }^{2}\right)\end{array}$ & $\begin{array}{c}\text { CTOD } \\
\text { (in.) }\end{array}$ & $\begin{array}{l}\text { CTOD } \\
\text { Plastic } \\
\text { (iil.) }\end{array}$ \\
\hline 1 & 68 & 0.0030 & 5965038 & 1.0000 & 0.0015 & 10624600 & 0.9980 & 20353 & -1 & 1 & 1.0379 & -0.0113 & 43 & 2 & 0.0000 & 0.0000 \\
\hline 2 & 93 & 0.0053 & 5850558 & 1.0000 & 0.0028 & 10790690 & 0.9993 & 32315 & 8 & 5 & 1.0448 & -0.0043 & 117 & 9 & 0.0000 & 0.0000 \\
\hline 3 & 70 & 0.0071 & 5818195 & .0000 & 0.0037 & 10826920 & 0.9996 & 39988 & 25 & 14 & 1.0468 & -0.0023 & 195 & 29 & 0.0000 & 0.0000 \\
\hline 4 & 77 & 0.0107 & 5775952 & 0.9999 & 0.0050 & 10464380 & 0.9990 & 50029 & 107 & 49 & 1.0495 & 0.0003 & 362 & 100 & 0.0000 & 0.0000 \\
\hline 5 & 88 & 0.0132 & 5721483 & 1.0000 & 0.0060 & 10363500 & 0.9991 & 53532 & 203 & 78 & 1.0529 & 0.0037 & 463 & 160 & 0.0000 & 0.0000 \\
\hline 6 & 105 & 0.0165 & 5616556 & 0.9999 & 0.0078 & 9968147 & 0.9993 & 58482 & 340 & 142 & 1.0595 & 0.0103 & 659 & 289 & 0.0000 & 0.0000 \\
\hline 7 & 67 & 0.0215 & 5516717 & 0.9999 & 0.0102 & 9903307 & 0.9993 & 62204 & 591 & 243 & 1.0660 & 0.0168 & 925 & 497 & 0.0000 & 0.0000 \\
\hline 8 & 66 & 0.0270 & 5445918 & 0.9999 & 0.0120 & 9701122 & 0.9998 & 63719 & 909 & 372 & 1.0706 & 0.0215 & 1217 & 762 & 0.0000 & 0.0000 \\
\hline 9 & 77 & 0.0323 & 5304970 & 0.9997 & 0.0148 & 9580219 & 0.9995 & 66453 & 1217 & 511 & 1.0801 & 0.0309 & 1554 & 1043 & 0.0000 & 0.0000 \\
\hline 10 & 63 & 0.0380 & 5259057 & 0.9999 & 0.0167 & 9745429 & 0.9995 & 65172 & 1597 & 664 & 1.0832 & 0.0341 & 1855 & 1359 & 0.0000 & 0.0000 \\
\hline 11 & 82 & 0.0444 & 5066077 & 0.9999 & 0.0194 & 9465190 & 0.9992 & 66660 & 2008 & 849 & 1.0967 & 0.0475 & 2272 & 1730 & 0.0000 & 0.0000 \\
\hline 12 & 89 & 0.0501 & 4891848 & 0.9997 & 0.0220 & 9182186 & 0.9995 & 69338 & 2333 & 996 & 1.1094 & 0.0602 & 2628 & 2017 & 0.0000 & 0.0000 \\
\hline 13 & 88 & 0.0559 & 4765410 & 0.9996 & 0.0246 & 8909041 & 0.9993 & 70141 & 2694 & 1153 & 1.1188 & 0.0696 & 2978 & 2334 & 0.0000 & 0.0000 \\
\hline 14 & 84 & 0.0602 & 4675659 & 0.9997 & 0.0265 & 9137088 & 0.9989 & 70603 & 2960 & 1264 & 1.1257 & 0.0765 & 3223 & 2556 & 0.0000 & 0.0000 \\
\hline 15 & 77 & 0.0652 & 4589528 & 0.9999 & 0.0282 & 8843632 & 0.9991 & 67990 & 3333 & 1427 & 1.1324 & 0.0832 & 3523 & 2891 & 0.0000 & 0.0000 \\
\hline 16 & 88 & 0.0689 & 4395055 & 0.9998 & 0.0298 & 8643606 & 0.9993 & 69038 & 3557 & 1519 & 1.1480 & 0.0988 & 3729 & 3044 & 0.0000 & 0.0000 \\
\hline 17 & 89 & 0.0725 & 4245726 & 0.9995 & 0.0315 & 8521231 & 0.9988 & 69464 & 3755 & 1618 & 1.1605 & 0.1113 & 3943 & 3222 & 0.0000 & 0.0000 \\
\hline 18 & 72 & 0.0760 & 4183181 & 0.9998 & 0.0328 & 8135579 & 0.9992 & 67793 & 3981 & 1712 & 1.1658 & 0.1166 & 4111 & 3412 & 0.0000 & 0.0000 \\
\hline 19 & 28 & 0.0835 & 4005280 & 0.9999 & 0.0356 & 8801837 & 0.9976 & 59487 & 4605 & 1949 & 1.1814 & 0.1323 & 4448 & 3882 & 0.0000 & 0.0000 \\
\hline
\end{tabular}




\begin{tabular}{|c|c|c|c|c|c|c|c|c|c|c|c|c|c|c|c|c|}
\hline $\begin{array}{c}\text { Unload } \\
\text { No. }\end{array}$ & $\begin{array}{c}\text { No. of } \\
\text { Data } \\
\text { Points }\end{array}$ & $\begin{array}{l}\text { COD } \\
\text { (in.) }\end{array}$ & $\begin{array}{l}\text { COD } \\
\text { Slope } \\
\text { (lb/in) }\end{array}$ & $\begin{array}{l}\text { COD } \\
\text { Corr. }\end{array}$ & $\begin{array}{l}\text { Loadline } \\
\text { Disp. } \\
\text { (in.) }\end{array}$ & $\begin{array}{c}\text { Loadline } \\
\text { Slope } \\
\text { (lb/in) }\end{array}$ & $\begin{array}{c}\text { Loadline } \\
\text { Corr. }\end{array}$ & $\begin{array}{l}\text { Load } \\
\text { (lb.) }\end{array}$ & $\begin{array}{c}\text { COD } \\
\text { Area } \\
(\text { in }-\mathrm{lb})\end{array}$ & $\begin{array}{c}\mathbf{L L} \\
\text { Area } \\
(\text { in-lb })\end{array}$ & $\begin{array}{c}\text { Crack } \\
\text { Length } \\
\text { (in.) }\end{array}$ & $\begin{array}{c}\text { Crack } \\
\text { Extension } \\
\text { (in.) }\end{array}$ & $\begin{array}{c}\mathrm{J} \\
\left(\mathrm{in}-\mathrm{lb} / \mathrm{in}^{2}\right)\end{array}$ & $\begin{array}{c}\text { J } \\
\text { Plastic } \\
\left(\text { in-lb/in }{ }^{2}\right)\end{array}$ & $\begin{array}{c}\text { CTOD } \\
\text { (in.) }\end{array}$ & $\begin{array}{c}\text { CIOD } \\
\text { Plastic } \\
\text { (in.) }\end{array}$ \\
\hline 1 & 57 & 0.0022 & 7414383 & 0.9998 & 0.0004 & 10757470 & 0.9995 & 19649 & -2 & -1 & 0.9605 & -0.0145 & 29 & -2 & 0.0000 & 0.0000 \\
\hline 2 & 66 & 0.0046 & 7215492 & 0.9998 & 0.0019 & 10243110 & 0.9997 & 35306 & 8 & 3 & 0.9701 & -0.0049 & 107 & 6 & 0.0000 & 0.0000 \\
\hline 3 & 96 & 0.0066 & 7214518 & 0.9998 & 0.0030 & 10864240 & 0.9999 & 45345 & 28 & 6 & 0.9701 & -0.0048 & 177 & 11 & 0.0000 & 0.0000 \\
\hline 4 & 88 & 0.0094 & 7314779 & 0.9999 & 0.0040 & 10247020 & 0.9997 & 54483 & 108 & 43 & 0.9652 & -0.0097 & 315 & 78 & 0.0000 & 0.0000 \\
\hline 5 & 56 & 0.0122 & 7102680 & 0.9999 & 0.0053 & 10736360 & 0.9999 & 60912 & 227 & 70 & 0.9756 & 0.0007 & 434 & 127 & 0.0000 & 0.0000 \\
\hline 6 & 77 & 0.0162 & 7017681 & 0.9997 & 0.0073 & 10282010 & 1.0000 & 66514 & 418 & 179 & 0.9799 & 0.0050 & 697 & 327 & 0.0000 & 0.0000 \\
\hline 7 & 99 & 0.0207 & 6865116 & 0.9996 & 0.0096 & 10313610 & 0.9999 & 69980 & 682 & 285 & 0.9877 & 0.0127 & 946 & 525 & 0.0000 & 0.0000 \\
\hline 8 & 74 & 0.0251 & 6884465 & 0.9999 & 0.0113 & 10282100 & 0.9998 & 71672 & 970 & 417 & 0.9867 & 0.0117 & 1211 & 772 & 0.0000 & 0.0000 \\
\hline 9 & 95 & 0.0295 & 6647964 & 0.9996 & 0.0137 & 10179460 & 1.0000 & 74211 & 1262 & 561 & 0.9991 & 0.0242 & 1537 & 1046 & 0.0000 & 0.0000 \\
\hline 10 & 86 & 0.0343 & 6612480 & 0.9997 & 0.0158 & 10075370 & 0.9999 & 75760 & 1583 & 717 & 1.0010 & 0.0261 & 1859 & 1344 & 0.0000 & 0.0000 \\
\hline 11 & 63 & 0.0379 & 6548157 & 0.9999 & 0.0172 & 9919492 & 0.9999 & 73455 & 1879 & 837 & 1.0045 & 0.0296 & 2064 & 1575 & 0.0000 & 0.0000 \\
\hline 12 & 79 & 0.0432 & 6333004 & 0.9996 & 0.0199 & 9811732 & 0.9997 & 78315 & 2229 & 1006 & 1.0164 & 0.0415 & 2487 & 1909 & 0.0000 & 0.0000 \\
\hline 13 & 85 & 0.0484 & 6292686 & 0.9997 & 0.0228 & 9822737 & 0.9999 & 79402 & 2594 & 1193 & 1.0187 & 0.0438 & 2874 & 2276 & 0.0000 & 0.0000 \\
\hline 14 & 61 & 0.0541 & 6111704 & 0.9996 & 0.0251 & 9527388 & 0.9998 & 80496 & 3025 & 1395 & 1.0292 & 0.0542 & 3316 & 2680 & 0.0000 & 0.0000 \\
\hline 15 & 74 & 0.0588 & 6081534 & 0.9998 & 0.0271 & 9711223 & 0.9999 & 78394 & 3408 & 1555 & 1.0309 & 0.0560 & 3608 & 3001 & 0.0000 & 0.0000 \\
\hline 16 & 73 & 0.0620 & 5914761 & 0.9995 & 0.0293 & 9644562 & 0.9999 & 81467 & 3620 & 1693 & 1.0409 & 0.0660 & 3960 & 3284 & 0.0000 & 0.0000 \\
\hline 17 & 73 & 0.0662 & 5752572 & 0.9999 & 0.0305 & 9334755 & 0.9999 & 79842 & 3954 & 1831 & 1.0509 & 0.0760 & 4205 & 3534 & 0.0000 & 0.0000 \\
\hline 18 & 72 & 0.0708 & 5702922 & 0.9997 & 0.0326 & 9301876 & 0.9999 & 80048 & 4294 & 1983 & 1.0540 & 0.0791 & 4516 & 3834 & 0.0000 & 0.0000 \\
\hline 19 & 87 & 0.0752 & 5485079 & 0.9995 & 0.0352 & 9128878 & 0.9999 & 81876 & 4621 & 2163 & 1.0681 & 0.0931 & 4897 & 4151 & 0.0000 & 0.0000 \\
\hline 20 & 85 & 0.0802 & 5292981 & 0.9995 & 0.0371 & 9001243 & 0.9998 & 81445 & 4985 & 2325 & 1.0809 & 0.1060 & 5203 & 4434 & 0.0000 & 0.0300 \\
\hline 21 & 83 & 0.0835 & 5156575 & 0.9999 & 0.0388 & 9044198 & 0.9998 & 81441 & 5215 & 2456 & 1.0903 & 0.1154 & 5460 & 4667 & 0.0000 & 0.0000 \\
\hline 22 & 49 & 0.0875 & 5074506 & 0.9998 & 0.0407 & 8667668 & 0.9998 & 81369 & 5507 & 2606 & 1.0961 & 0.1212 & 5764 & 4958 & 0.0000 & 0.0000 \\
\hline 23 & 54 & 0.0927 & 4855994 & 0.9995 & 0.0425 & 8661276 & 0.9999 & 79052 & 5937 & 2746 & 1.1120 & 0.1371 & 5975 & 5175 & 0.0000 & 0.0000 \\
\hline 24 & 46 & 0.0955 & 4860986 & 0.9999 & 0.0436 & 8636520 & 0.9999 & 77637 & 6133 & 2847 & 1.1116 & 0.1367 & 6164 & 5393 & 0.0000 & 0.0000 \\
\hline 25 & 51 & 0.1020 & 4657607 & 0.9997 & 0.0463 & 8485046 & 0.9999 & 75908 & 6670 & 3076 & 1.1271 & 0.1521 & 6571 & 5796 & 0.0000 & 0.0000 \\
\hline
\end{tabular}




\begin{tabular}{|c|c|c|c|c|c|c|c|c|c|c|c|c|c|c|c|c|}
\hline $\begin{array}{l}\text { Unload } \\
\text { No. }\end{array}$ & $\begin{array}{c}\text { No. of } \\
\text { Data } \\
\text { Points }\end{array}$ & $\begin{array}{l}\text { COD } \\
\text { (in.) }\end{array}$ & $\begin{array}{l}\text { COD } \\
\text { Slope } \\
\text { (lb/in) }\end{array}$ & $\begin{array}{l}\text { COD } \\
\text { Corr. }\end{array}$ & $\begin{array}{c}\text { Loadline } \\
\text { Disp. } \\
\text { (in.) }\end{array}$ & $\begin{array}{c}\text { Loadline } \\
\text { Slope } \\
\text { (lb/in) }\end{array}$ & $\begin{array}{c}\text { Loadline } \\
\text { Corr. }\end{array}$ & $\begin{array}{l}\text { Load } \\
\text { (lb.) }\end{array}$ & $\begin{array}{c}\text { COD } \\
\text { Areabl } \\
\text { (in-lb) }\end{array}$ & $\begin{array}{c}\text { LL } \\
\text { Area } \\
\text { (in-lb) }\end{array}$ & $\begin{array}{c}\text { Crack } \\
\text { Length } \\
\text { (in.) }\end{array}$ & $\begin{array}{c}\text { Crack } \\
\text { Extension } \\
\text { (in.) }\end{array}$ & $\begin{array}{c}J \\
\left(\mathrm{in}-\mathrm{lb} / \mathrm{in}^{2}\right)\end{array}$ & $\begin{array}{c}J \\
\text { Plastic } \\
\left(\text { in-lb/in }{ }^{2}\right)\end{array}$ & $\begin{array}{l}\text { CTOD } \\
\text { (in.) }\end{array}$ & $\begin{array}{c}\text { CTOD } \\
\text { Plastic } \\
\text { (in.) }\end{array}$ \\
\hline 1 & 32 & 0.0061 & 1427498 & 1.0000 & 0.0015 & 3752655 & 0.998 .5 & 10094 & -3 & -2 & 1.5336 & -0.0095 & 60 & 6 & 0.0000 & 0.0000 \\
\hline 2 & 60 & 0.0147 & 1410446 & 1.0000 & 0.0044 & 3519185 & 0.9998 & 18419 & 43 & 15 & 1.5374 & -0.0057 & 240 & 57 & 0.0000 & 0.0000 \\
\hline 3 & 72 & 0.0205 & 1386163 & 1.0000 & 0.0065 & 3494279 & 0.9999 & 21698 & 112 & 34 & 1.5429 & -0.0003 & 374 & 114 & 0.0000 & 0.0000 \\
\hline 4 & 88 & 0.0258 & 1368060 & 0.9999 & 0.0087 & 3414189 & 0.9999 & 24060 & 191 & 63 & 1.5470 & 0.0039 & 528 & 203 & 0.0000 & 0.0000 \\
\hline 5 & 86 & 0.0319 & 1360647 & 0.9999 & 0.0107 & 3439928 & 0.9997 & 25086 & 318 & 108 & 1.5487 & 0.0056 & 699 & 343 & 0.0000 & 0.0000 \\
\hline 6 & 90 & 0.0380 & 1328448 & 0.9998 & 0.0131 & 3387869 & 0.9995 & 26234 & 450 & 159 & 1.5562 & 0.0131 & 902 & 501 & 0.0000 & 0.0000 \\
\hline 7 & 88 & 0.0418 & 1353081 & 0.9999 & 0.0144 & 3408681 & 0.9994 & 26650 & 532 & 189 & 1.5505 & 0.0073 & 1003 & 599 & 0.0000 & 0.0000 \\
\hline 8 & 85 & 0.0460 & 1346086 & 0.9999 & 0.0157 & 3406492 & 0.9990 & 26590 & 655 & 231 & 1.5521 & 0.0090 & 1135 & 730 & 0.0000 & 0.0000 \\
\hline 9 & 70 & 0.0508 & 1324479 & 0.9998 & 0.0178 & 3431236 & 0.9982 & 27431 & 766 & 277 & 1.5571 & 0.0140 & 1306 & 866 & 0.0000 & 0.0000 \\
\hline 10 & 76 & 0.0552 & 1321325 & 0.9999 & 0.0192 & 3450574 & 0.9983 & 27322 & 882 & 323 & 1.5579 & 0.0148 & 1448 & 1010 & 0.0000 & 0.0000 \\
\hline 11 & 82 & 0.0597 & 1303667 & 0.9998 & 0.0211 & 3347904 & 0.9982 & 27959 & 992 & 367 & 1.5621 & 0.0190 & 1609 & 1143 & 0.0000 & 0.0000 \\
\hline 12 & 65 & 0.0648 & 1307148 & 0.9999 & 0.0228 & 3435686 & 0.9981 & 27814 & 1131 & 413 & 1.5612 & 0.0181 & 1752 & 1292 & 0.0000 & 0.0000 \\
\hline 13 & 89 & 0.0696 & 1267196 & 0.9998 & 0.0248 & 3365415 & 0.9988 & 28346 & 1256 & 468 & 1.5709 & 0.0278 & 1943 & 1447 & 0.0000 & 0.0000 \\
\hline 14 & 89 & 0.0742 & 1260008 & 0.9998 & 0.0264 & 3345582 & 0.9979 & 28545 & 1364 & 510 & 1.5726 & 0.0295 & 2084 & 1577 & 0.0000 & 0.0000 \\
\hline 15 & 94 & 0.0781 & 1246254 & 0.9998 & 0.0282 & 3345445 & 0.9983 & 28665 & 1468 & 549 & 1.5760 & 0.0329 & 2213 & 1694 & 0.0000 & 0.0000 \\
\hline 16 & 102 & 0.0823 & 1229242 & 0.9998 & 0.0298 & 3272721 & 0.9986 & 28705 & 1580 & 592 & 1.5803 & 0.0372 & 2350 & 1820 & 0.0000 & 0.0000 \\
\hline 17 & 87 & 0.0867 & 1224899 & 0.9998 & 0.0309 & 3299973 & 0.9979 & 28511 & 1702 & 633 & 1.5814 & 0.0383 & 2477 & 1952 & 0.0000 & 0.0000 \\
\hline 18 & 83 & 0.0906 & 1198186 & 0.9998 & 0.0326 & 3215180 & 0.9976 & 28790 & 1806 & 677 & 1.5881 & 0.0450 & 2625 & 2075 & 0.0000 & 0.0000 \\
\hline 19 & 24 & 0.0910 & 1266572 & 1.0000 & 0.0324 & 4319342 & 0.9709 & 28087 & 1820 & 680 & 1.5710 & 0.0279 & 2623 & 2135 & 0.0000 & 0.0000 \\
\hline 20 & 51 & 0.0955 & 1194741 & 0.9999 & 0.0341 & 3319325 & 0.9975 & 27404 & 2000 & 800 & 1.5890 & 0.0459 & 2959 & 2459 & 0.0000 & 0.0000 \\
\hline 21 & 60 & 0.1004 & 1175860 & 0.9999 & 0.0359 & 3186526 & 0.9971 & 27625 & 2099 & 796 & 1.5939 & 0.0508 & 2947 & 2427 & 0.0000 & 0.0000 \\
\hline 22 & 60 & 0.1057 & 1156785 & 0.9999 & 0.0379 & 3244890 & 0.9975 & 28049 & 2232 & 839 & 1.5989 & 0.0558 & 3098 & 2551 & 0.0000 & 0.0000 \\
\hline 23 & 63 & 0.1110 & 1130080 & 0.9998 & 0.0399 & 3067891 & 0.9977 & 28501 & 2361 & 896 & 1.6060 & 0.0629 & 3291 & 2709 & 0.0000 & 0.0000 \\
\hline 24 & 60 & 0.1156 & 1118156 & 0.9999 & 0.0416 & 3085430 & 0.9970 & 27511 & 2503 & 945 & 1.6092 & 0.0661 & 3409 & 2859 & 0.0000 & 0.0000 \\
\hline 25 & 61 & 0.1206 & 1091045 & 0.9998 & 0.0442 & 3029391 & 0.9973 & 28574 & 2611 & 993 & 1.6166 & 0.0735 & 3596 & 2984 & 0.0000 & 0.0000 \\
\hline 26 & 66 & 0.1252 & 1069207 & 0.9997 & 0.0458 & 2936597 & 0.9969 & 28599 & 2725 & 1039 & 1.6227 & 0.0795 & 3740 & 3111 & 0.0000 & 0.0000 \\
\hline 27 & 67 & 0.1292 & 1057094 & 0.9998 & 0.0476 & 2859142 & 0.9980 & 28620 & 2821 & 1074 & 1.6261 & 0.0829 & 3855 & 3215 & 0.0000 & 0.0000 \\
\hline 28 & 63 & 0.1347 & 1041935 & 0.9998 & 0.0490 & 2900105 & 0.9977 & 27730 & 2994 & 1137 & 1.6304 & 0.0873 & 4017 & 3405 & 0.0000 & 0.0000 \\
\hline 29 & 67 & 0.1394 & 1005748 & 0.9997 & 0.0516 & 2787984 & 0.9983 & 28165 & 3103 & 1191 & 1.6409 & 0.0978 & 4195 & 3533 & 0.0000 & 0.0000 \\
\hline 30 & 61 & 0.1451 & 999857 & 0.9999 & 0.0529 & 2762932 & 0.9983 & 26819 & 3273 & 1253 & 1.6426 & 0.0995 & 4340 & 3735 & 0.0000 & 0.0000 \\
\hline 31 & 70 & 0.1496 & 971391 & 0.9997 & 0.0555 & 2658105 & 0.9980 & 27961 & 3362 & 1291 & 1.6511 & 0.1080 & 4500 & 3818 & 0.0000 & 0.0000 \\
\hline 32 & 74 & 0.1550 & 948416 & 0.9996 & 0.0576 & 2620783 & 0.9975 & 27661 & 3498 & 1344 & 1.6581 & 0.1150 & 4647 & 3958 & 0.0000 & 0.0000 \\
\hline 33 & 61 & 0.1620 & 934070 & 0.9999 & 0.0598 & 2685481 & 0.9975 & 25631 & 3727 & 1435 & 1.6626 & 0.1195 & 4854 & 4250 & 0.0000 & 0.0000 \\
\hline
\end{tabular}




\begin{tabular}{|c|c|c|c|c|c|c|c|c|c|c|c|c|c|c|c|c|}
\hline $\begin{array}{c}\text { Unload } \\
\text { No. }\end{array}$ & $\begin{array}{c}\text { No. of } \\
\text { Data } \\
\text { Points }\end{array}$ & $\begin{array}{l}\text { COD } \\
\text { (in.) }\end{array}$ & $\begin{array}{l}\text { COD } \\
\text { Slope } \\
\text { (lb/in) }\end{array}$ & $\begin{array}{l}\text { COD } \\
\text { Corr. }\end{array}$ & $\begin{array}{c}\text { Loadline } \\
\text { Disp. } \\
\text { (in.) }\end{array}$ & $\begin{array}{c}\text { Loadline } \\
\text { Slope } \\
\text { (lb/in) }\end{array}$ & $\begin{array}{c}\text { Loadline } \\
\text { Corr. }\end{array}$ & $\begin{array}{l}\text { Load } \\
\text { (lb.) }\end{array}$ & $\begin{array}{l}\text { COD } \\
\text { Area } \\
(\text { in }-1 b)\end{array}$ & $\begin{array}{c}\text { LL } \\
\text { Area } b ! \\
(i n-1 b)\end{array}$ & $\begin{array}{c}\text { Crack } \\
\text { Length } \\
\text { (in.) } \\
\end{array}$ & $\begin{array}{c}\text { Crack } \\
\text { Extension } \\
\text { (ii).) }\end{array}$ & $\begin{array}{c}J \\
\left(i n-l b / i^{2}\right)\end{array}$ & $\begin{array}{c}\mathbf{J} \\
\text { Plastic } \\
\left(\mathrm{in}-\mathrm{lb} / \mathrm{in}^{2}\right)\end{array}$ & $\begin{array}{l}\text { CTOD } \\
\text { (in.) }\end{array}$ & $\begin{array}{c}\text { CTOD } \\
\text { Plastic } \\
\text { (in.) }\end{array}$ \\
\hline 1 & 57 & 0.0041 & 5820876 & 1.0000 & 0.0026 & 8377966 & 0.9999 & 25458 & 1 & -0 & 1.0467 & 0.0134 & 67 & -0 & 0.0000 & 0.0000 \\
\hline 2 & 43 & 0.0042 & 5892000 & 0.9999 & 0.0023 & 8263827 & 0.9995 & 25499 & -2 & -2 & 1.0423 & 0.0090 & 64 & -3 & 0.0000 & 0.0000 \\
\hline 3 & 70 & 0.0074 & 5983493 & 1.0000 & 0.0043 & 8665973 & 1.0000 & 39323 & 31 & 2 & 1.0368 & 0.0035 & 161 & 5 & 0.0000 & 0.0000 \\
\hline 4 & 81 & 0.0105 & 6033523 & 1.0000 & 0.0064 & 8819825 & 0.9999 & 49930 & 97 & 45 & 1.0338 & 0.0005 & 339 & 91 & 0.0000 & 0.0000 \\
\hline 5 & 93 & 0.0123 & 6073684 & 1.0000 & 0.0068 & 8660561 & 0.9999 & 52773 & 173 & 71 & 1.0314 & -0.0019 & 418 & 143 & 0.0000 & 0.0000 \\
\hline 6 & 87 & 0.0139 & 6045995 & 1.0000 & 0.0077 & 8662960 & 0.9999 & 56.502 & 231 & 94 & 1.0330 & -0.0002 & 508 & 190 & 0.0000 & 0.0000 \\
\hline 7 & 82 & 0.0157 & 6175700 & 1.0000 & 0.0084 & 8718228 & 0.9999 & 57322 & 324 & 130 & 1.0254 & -0.0078 & 579 & 260 & 0.0000 & 0.0000 \\
\hline 8 & 75 & 0.0177 & 6140434 & 0.9999 & 0.0101 & 8688816 & 0.9999 & 60857 & 423 & 188 & 1.0275 & -0.0058 & 739 & 377 & 0.0000 & 0.0000 \\
\hline 9 & 90 & 0.0201 & 6052324 & 0.9999 & 0.0109 & 8635654 & 1.0000 & 62882 & 546 & 248 & 1.0327 & -0.0006 & 890 & 497 & 0.0000 & 0.0000 \\
\hline 10 & 84 & 0.0226 & 6072886 & 0.9999 & 0.0125 & 8821430 & 0.9999 & 64414 & 680 & 311 & 1.0315 & -0.0018 & 1035 & 624 & 0.0000 & 0.0000 \\
\hline 11 & 65 & 0.0252 & 6066690 & 0.9999 & 0.0131 & 8765622 & 0.9999 & 65234 & 845 & 379 & 1.0318 & -0.0015 & 1181 & 759 & 0.0000 & 0.0000 \\
\hline 12 & 51 & 0.0286 & 5969952 & 0.9998 & 0.0151 & 8825389 & 0.9998 & 67713 & 1041 & 478 & 1.0376 & 0.0043 & 1422 & 960 & 0.0000 & 0.0000 \\
\hline 13 & 48 & 0.0324 & 5973922 & 0.9999 & 0.0169 & 8735941 & 0.9999 & 69203 & 1270 & 590 & 1.0373 & 0.0041 & 1670 & 1187 & 0.0000 & 0.0000 \\
\hline 14 & 50 & 0.0378 & 5932219 & 0.9999 & 0.0186 & 8706343 & 0.9999 & 69130 & 1650 & 729 & 1.0399 & 0.0066 & 1957 & 1471 & 0.0000 & 0.0000 \\
\hline 15 & 69 & 0.0417 & 5810894 & 0.9997 & 0.0206 & 8541882 & 0.9999 & 71648 & 1892 & 845 & 1.0473 & 0.0140 & 2230 & 1696 & 0.0000 & 0.0000 \\
\hline 16 & 67 & 0.0458 & 5818106 & 0.9998 & 0.0231 & 8399419 & 0.9998 & 73031 & 2158 & 975 & 1.0468 & 0.0136 & 2517 & 1962 & 0.0000 & 0.0000 \\
\hline 17 & 82 & 0.0500 & 5661098 & 0.9997 & 0.0248 & 8536582 & 0.9998 & 73727 & 2456 & 1101 & 1.0567 & 0.0234 & 2784 & 2200 & 0.0000 & 0.0000 \\
\hline 18 & 70 & 0.0534 & 5658561 & 0.9997 & 0.0262 & 8228313 & 0.9999 & 74407 & 2676 & 1217 & 1.0568 & 0.0236 & 3034 & 2439 & 0.0000 & 0.0000 \\
\hline 19 & 84 & 0.0569 & 5545916 & 0.9997 & 0.0282 & 8267812 & 0.9998 & 74950 & 2931 & 1308 & 1.0641 & 0.0308 & 3227 & 2610 & 0.0000 & 0.0000 \\
\hline 20 & 55 & 0.0603 & 5474049 & 0.9995 & 0.0291 & 8286485 & 0.9999 & 75898 & 3153 & 1408 & 1.0688 & 0.0355 & 3448 & 2806 & 0.0000 & 0.0000 \\
\hline 21 & 30 & 0.0638 & 5605029 & 0.9999 & 0.0303 & 8269452 & 0.9999 & 72090 & 3456 & 1538 & 1.0603 & 0.0270 & 3662 & 3098 & 0.0000 & 0.0000 \\
\hline 22 & 61 & 0.0678 & 5273052 & 0.9996 & 0.0325 & 8173204 & 0.9998 & 76284 & 3726 & 1668 & 1.0823 & 0.0490 & 3977 & 3299 & 0.0000 & 0.0000 \\
\hline 23 & 42 & 0.0714 & 5358565 & 0.9999 & 0.0337 & 8320051 & 0.9998 & 73810 & 3970 & 1774 & 1.0765 & 0.0432 & 4165 & 3542 & 0.0000 & 0.0000 \\
\hline 24 & 67 & 0.0763 & 5044710 & 0.9995 & 0.0361 & 7903071 & 0.9996 & 76381 & 4324 & 1945 & 1.0982 & 0.0650 & 4535 & 3820 & 0.0000 & 0.0000 \\
\hline 25 & 60 & 0.0811 & 5019737 & 0.9997 & 0.0384 & 7822509 & 0.9997 & 76828 & 4616 & 2081 & 1.1000 & 0.0668 & 4829 & 4101 & 0.0000 & 0.0000 \\
\hline 26 & 51 & 0.0851 & 4968394 & 0.9998 & 0.0396 & 7931650 & 0.9999 & 73863 & 4960 & 2193 & 1.1038 & 0.0705 & 5005 & 4325 & 0.0000 & 0.0000 \\
\hline 27 & 48 & 0.0891 & 4846393 & 0.9998 & 0.0413 & 7925313 & 0.9998 & 74431 & 5246 & 2329 & 1.1127 & 0.0794 & 5286 & 4575 & 0.0000 & 0.0000 \\
\hline 28 & 63 & 0.0936 & 4655629 & 0.9995 & 0.0435 & 7580592 & 0.9998 & 76309 & 5537 & 2479 & 1.1272 & 0.0939 & 5613 & 4830 & 0.0000 & 0.0000 \\
\hline 29 & 49 & 0.0993 & 4561200 & 0.9998 & 0.0465 & 7604264 & 0.9995 & 76249 & 5921 & 2665 & 1.1346 & 0.1013 & 5996 & 5195 & 0.0000 & 0.0000 \\
\hline 30 & 31 & 0.1059 & 4449850 & 0.9999 & 0.0486 & 7447062 & 0.9998 & 69136 & 6512 & 2900 & 1.1435 & 0.1103 & 6335 & 5658 & 0.0000 & 0.0000 \\
\hline 31 & 44 & 0.1114 & 4241703 & 0.9999 & 0.0511 & 7195850 & 0.9998 & 727.54 & 6833 & 3043 & 1.1608 & 0.1275 & 6662 & 5870 & 0.0000 & 0.0000 \\
\hline 32 & 52 & 0.1159 & 4087774 & 0.9995 & 0.0532 & 7099207 & 0.9996 & 74143 & 7084 & 3164 & 1.1741 & 0.1408 & 6914 & 6056 & 0.0000 & 0.0000 \\
\hline
\end{tabular}




\begin{tabular}{|c|c|c|c|c|c|c|c|c|c|c|c|c|c|c|c|c|}
\hline $\begin{array}{c}\text { Unload } \\
\text { No. }\end{array}$ & $\begin{array}{c}\text { No. of } \\
\text { Data } \\
\text { Points }\end{array}$ & $\begin{array}{l}C O D \\
\text { (in.) }\end{array}$ & $\begin{array}{l}\text { COD } \\
\text { Slope } \\
\text { (lb/in) }\end{array}$ & $\begin{array}{l}\text { COD } \\
\text { Corr. }\end{array}$ & $\begin{array}{c}\text { Loadline } \\
\text { Disp. } \\
\text { (in.) }\end{array}$ & $\begin{array}{c}\text { Loadline } \\
\text { Slope } \\
\text { (lb/in) }\end{array}$ & $\begin{array}{c}\text { Loadline } \\
\text { Corr. }\end{array}$ & $\begin{array}{l}\text { Load } \\
\text { (lb.) }\end{array}$ & $\begin{array}{c}\text { COD } \\
\text { Area } \\
\text { (in-lb) }\end{array}$ & $\begin{array}{c}\text { LL } \\
\text { Area } \\
(\text { in }- \text { lb })\end{array}$ & $\begin{array}{c}\text { Crack } \\
\text { Length } \\
\text { (in.) }\end{array}$ & $\begin{array}{c}\text { Crack } \\
\text { Extension } \\
\text { (in.) }\end{array}$ & $\begin{array}{c}J \\
\left(\mathrm{in}-\mathrm{lb} / \mathrm{in}^{2}\right)\end{array}$ & $\begin{array}{c}\mathbf{J} \\
\text { Plastic } \\
\left(\mathrm{in}-\mathrm{lb} / \mathrm{in}^{2}\right)\end{array}$ & $\begin{array}{l}\text { CTOD } \\
\text { (in.) }\end{array}$ & $\begin{array}{c}\text { CrOD } \\
\text { Plastic } \\
\text { (in.) }\end{array}$ \\
\hline 1 & 35 & 0.0063 & 1426629 & 1.0000 & 0.0031 & 3374840 & 0.9976 & 10188 & -3 & -0 & 1.5338 & -0.0047 & 56 & 1 & 0.0000 & 0.0000 \\
\hline 2 & 67 & 0.0105 & 1439917 & 0.9999 & 0.0047 & 3618585 & 0.9986 & 14983 & 9 & 4 & 1.5308 & -0.0077 & 131 & 13 & 0.0000 & 0.0000 \\
\hline 3 & 42 & 0.0173 & 1403117 & 1.0000 & 0.0073 & 3351691 & 0.9995 & 20183 & 68 & 32 & 1.5390 & 0.0005 & 322 & 100 & 0.0000 & 0.0000 \\
\hline 4 & 55 & 0.0245 & 1404206 & 0.9999 & 0.0103 & 3385078 & 0.9987 & 23169 & 171 & 67 & 1.5388 & 0.0003 & 500 & 209 & 0.0000 & 0.0000 \\
\hline 5 & 86 & 0.0343 & 1347951 & 0.9997 & 0.0141 & 3291286 & 0.9989 & 25052 & 378 & 149 & 1.5516 & 0.0131 & 816 & 457 & 0.0000 & 0.0000 \\
\hline 6 & 79 & 0.0396 & 1358997 & 0.9998 & 0.0159 & 3454909 & 0,9983 & 25621 & 483 & 191 & 1.5491 & 0.0106 & 962 & 590 & 0.0000 & 0.0000 \\
\hline 7 & 74 & 0.0455 & 1345948 & 0.9998 & 0.0182 & 3445719 & 0.9978 & 26148 & 630 & 257 & 1.5521 & 0.0136 & 1186 & 794 & 0.0000 & 0.0000 \\
\hline 8 & 68 & 0.0505 & 1327835 & 0.9998 & 0.0203 & 3270237 & 0.9992 & 26382 & 752 & 304 & 1.5563 & 0.0178 & 1341 & 936 & 0.0000 & 0.0000 \\
\hline 9 & 65 & 0.0569 & 1314433 & 0.9999 & 0.0222 & 3354514 & 0.9985 & 26026 & 920 & 355 & 1.5595 & 0.0210 & 1493 & 1093 & 0.0000 & 0.0000 \\
\hline 10 & 68 & 0.0636 & 1271962 & 0.9998 & 0.0248 & 3415065 & 0.9994 & 26314 & 1087 & 427 & 1.5697 & 0.0312 & 1728 & 1302 & 0.0000 & 0.0000 \\
\hline 11 & 81 & 0.0699 & 1242330 & 0.9998 & 0.0272 & 3158322 & 0.9990 & 26656 & 1233 & 492 & 1.5770 & 0.0385 & 1945 & 1495 & 0.0000 & 0.0000 \\
\hline 12 & 81 & 0.0757 & 1231984 & 0.9998 & 0.0298 & 3103330 & 0.9972 & 26702 & 1371 & 534 & 1.5796 & 0.0411 & 2083 & 1626 & 0.0000 & 0.0000 \\
\hline 13 & 75 & 0.0819 & 1200225 & 0.9997 & 0.0315 & 3059812 & 0.9984 & 26401 & 1540 & 591 & 1.5876 & 0.0491 & 2252 & 1790 & 0.0000 & 0.0000 \\
\hline 14 & 81 & 0.0889 & 1171899 & 0.9998 & 0.0341 & 3066204 & 0.9987 & 26315 & 1712 & 657 & 1.5949 & 0.0564 & 2456 & 1983 & 0.0000 & 0.0000 \\
\hline 15 & 84 & 0.0955 & 1158539 & 0.9997 & 0.0368 & 2955039 & 0.9987 & 26549 & 1870 & 726 & 1.5984 & 0.0599 & 2688 & 2199 & 0.0000 & 0.0000 \\
\hline 16 & 79 & 0.1017 & 1130203 & 0.9999 & 0.0388 & 2961791 & 0.9971 & 25725 & 2045 & 781 & 1.6059 & 0.0674 & 2830 & 2356 & 0.0000 & 0.0000 \\
\hline 17 & 48 & 0.1085 & 1098333 & 0.9997 & 0.0413 & 2923681 & 0.9980 & 25851 & 2205 & 847 & 1.6146 & 0.0761 & 3039 & 2542 & 0.0000 & 0.0000 \\
\hline 18 & 62 & 0.1149 & 1068097 & 0.9998 & 0.0443 & 2786389 & 0.9987 & 26015 & 2351 & 909 & 1.6230 & 0.0844 & 3237 & 2715 & 0.0000 & 0.0000 \\
\hline 19 & 67 & 0.1225 & 1031632 & 0.9996 & 0.0467 & 2775242 & 0.9987 & 25767 & 2538 & 973 & 1.6333 & 0.0948 & 3421 & 2886 & 0.0000 & 0.0000 \\
\hline 20 & 58 & 0.1289 & 999059 & 0.9999 & 0.0486 & 2726544 & 0.9975 & 24419 & 2712 & 1034 & 1.6428 & 0.1043 & 3554 & 3052 & 0.0000 & 0.0000 \\
\hline 21 & 65 & 0.1336 & 951056 & 0.9997 & 0.0510 & 2592549 & 0.9990 & 24732 & 2803 & 1075 & 1.6573 & 0.1188 & 3669 & 3119 & 0.0000 & 0.0000 \\
\hline 22 & 82 & 0.1392 & 907319 & 0.9997 & 0.0526 & 2498056 & 0.9981 & 23842 & 2931 & 1120 & 1.6710 & 0.1325 & 3751 & 3208 & 0.0000 & 0.0000 \\
\hline 23 & 53 & 0.1427 & 892984 & 0.9999 & 0.0534 & 2619626 & 0.9978 & 22507 & 3018 & 1146 & 1.6756 & 0.1371 & 3769 & 3274 & 0.0000 & 0.0000 \\
\hline 24 & 50 & 0.1468 & 857420 & 0.9998 & 0.0549 & 2606002 & 0.9968 & 21691 & 3122 & 1198 & 1.6873 & 0.1488 & 3883 & 3398 & 0.0000 & 0.0000 \\
\hline
\end{tabular}




\begin{tabular}{|c|c|c|c|c|c|c|c|c|c|c|c|c|c|c|c|c|}
\hline $\begin{array}{c}\text { Unload } \\
\text { No. }\end{array}$ & $\begin{array}{c}\text { No. of } \\
\text { Data } \\
\text { Points }\end{array}$ & $\begin{array}{l}\text { COD } \\
\text { (in.) }\end{array}$ & $\begin{array}{c}\text { COD } \\
\text { Slope } \\
\text { (lb/in) }\end{array}$ & $\begin{array}{l}\text { COD } \\
\text { Corr. }\end{array}$ & $\begin{array}{c}\text { Loadline } \\
\text { Disp. } \\
\text { (in.) }\end{array}$ & $\begin{array}{c}\text { Loadline } \\
\text { Slope } \\
\text { (lb/in) }\end{array}$ & $\begin{array}{l}\text { Loadline } \\
\text { Corr. }\end{array}$ & $\begin{array}{l}\text { Load } \\
\text { (lb.) }\end{array}$ & $\begin{array}{c}\text { COD } \\
\text { Area } \\
\text { (in-lb) }\end{array}$ & $\begin{array}{c}\mathrm{LL} \\
\text { Area }_{\mathrm{bl}} \\
(\mathrm{in}-\mathrm{lb})\end{array}$ & $\begin{array}{c}\text { Crack } \\
\text { Length } \\
\text { (in.) }\end{array}$ & $\begin{array}{c}\text { Crack } \\
\text { Extension } \\
\text { (in.) } \\
\end{array}$ & $\begin{array}{c}J \\
\left(\mathrm{in}-\mathrm{lb} / \mathrm{in}^{2}\right)\end{array}$ & $\begin{array}{c}J \\
\text { Plastic } \\
\left(\text { in-lb/in }{ }^{2}\right)\end{array}$ & $\begin{array}{l}\text { CTOD } \\
\text { (in.) } \\
\end{array}$ & $\begin{array}{c}\text { CTOD } \\
\text { Plastic } \\
\text { (in.) }\end{array}$ \\
\hline 1 & 59 & 0.0012 & 13217300 & 0.9997 & 0.0012 & 13217300 & 0.9997 & 20233 & -1 & -3 & 0.8873 & -0.0441 & 6 & -8 & 0.0000 & 0.0000 \\
\hline 2 & 81 & 0.0021 & 12877550 & 0.9999 & 0.0020 & 12877550 & 0.9999 & 30185 & 1 & 3 & 0.9030 & -0.0284 & 30 & -2 & 0.0000 & 0.0000 \\
\hline 3 & 79 & 0.0029 & 12759120 & 0.9999 & 0.0028 & 12759120 & 0.9999 & 40124 & 2 & 4 & 0.9085 & -0.0229 & 56 & -1 & 0.0000 & 0.0000 \\
\hline 4 & 112 & 0.0039 & 12861940 & 0.9999 & 0.0035 & 12861940 & 0.9999 & 50166 & 11 & 13 & 0.9037 & -0.0277 & 95 & 7 & 0.0000 & 0.0000 \\
\hline 5 & 65 & 0.0063 & 12385390 & 0.9998 & 0.0062 & 12385390 & 0.9998 & 58251 & 109 & 111 & 0.9261 & -0.0053 & 242 & 115 & 0.0000 & 0.0000 \\
\hline 6 & 95 & 0.0079 & 12366440 & 0.9998 & 0.0078 & 12366440 & 0.9998 & 59859 & 188 & 190 & 0.9270 & -0.0044 & 332 & 198 & 0.0000 & 0.0000 \\
\hline 7 & 98 & 0.0098 & 12317090 & 0.9998 & 0.0098 & 12317090 & 0.9998 & 61242 & 294 & 296 & 0.9293 & -0.0021 & 453 & 311 & 0.0000 & 0.0000 \\
\hline 8 & 68 & 0.0121 & 12208190 & 0.9999 & 0.0118 & 12208190 & 0.9999 & 62918 & 426 & 428 & 0.9345 & 0.0031 & 610 & 458 & 0.0000 & 0.0000 \\
\hline 9 & 78 & 0.0139 & 12104860 & 0.9998 & 0.0133 & 12104860 & 0.9998 & 64024 & 534 & 535 & 0.9395 & 0.0080 & 742 & 581 & 0.0000 & 0.0000 \\
\hline 10 & 87 & 0.0150 & 12094380 & 0.9998 & 0.0145 & 12094380 & 0.9998 & 64854 & 598 & 600 & 0.9400 & 0.0085 & 817 & 653 & 0.0000 & 0.0000 \\
\hline 11 & 74 & 0.0169 & 12019200 & 0.9997 & 0.0166 & 12019200 & 0.9997 & 65575 & 718 & 720 & 0.9436 & 0.0121 & 962 & 791 & 0.0000 & 0.0000 \\
\hline 12 & 125 & 0.0187 & 11879540 & 0.9998 & 0.0186 & 11879540 & 0.9998 & 66306 & 833 & 835 & 0.9503 & 0.0189 & 1115 & 936 & 0.0000 & 0.0000 \\
\hline 13 & 58 & 0.0215 & 11806250 & 0.9997 & 0.0211 & 11806250 & 0.9997 & 67358 & 1006 & 1008 & 0.9538 & 0.0224 & 1329 & 1143 & 0.0000 & 0.0000 \\
\hline 14 & 72 & 0.0236 & 11728880 & 0.9998 & 0.0232 & 11728880 & 0.9998 & 68079 & 1145 & 1146 & 0.9575 & 0.0261 & 1508 & 1315 & 0.0000 & 0.0000 \\
\hline 15 & 67 & 0.0252 & 11766620 & 0.9998 & 0.0244 & 11766620 & 0.9998 & 66877 & 1256 & 1258 & 0.9557 & 0.0243 & 1621 & 1436 & 0.0000 & 0.0000 \\
\hline 16 & 83 & 0.0275 & 11532490 & 0.9997 & 0.0269 & 11532490 & 0.9997 & 69042 & 1405 & 1407 & 0.9671 & 0.0356 & 1867 & 1661 & 0.0000 & 0.0000 \\
\hline 17 & 79 & 0.0296 & 11547490 & 0.9998 & 0.0289 & 11547490 & 0.9998 & 69327 & 1539 & 1541 & 0.9663 & 0.0349 & 2024 & 1817 & 0.0000 & 0.0000 \\
\hline 18 & 77 & 0.0315 & 11466600 & 0.9997 & 0.0308 & 11466600 & 0.9997 & 69500 & 1674 & 1675 & 0.9703 & 0.0388 & 2211 & 2000 & 0.0000 & 0.0000 \\
\hline 19 & 78 & 0.0334 & 11491190 & 0.9998 & 0.0328 & 11491190 & 0.9998 & 69770 & 1801 & 1803 & 0.9691 & 0.0377 & 2358 & 2146 & 0.0000 & 0.0000 \\
\hline 20 & 76 & 0.0354 & 11292960 & 0.9998 & 0.0347 & 11292960 & 0.9998 & 69623 & 1941 & 1943 & 0.9787 & 0.0473 & 2600 & 2381 & 0.0000 & 0.0000 \\
\hline 21 & 81 & 0.0372 & 11258180 & 0.9998 & 0.0364 & 11258180 & 0.9998 & 68336 & 2066 & 2068 & 0.9804 & 0.0490 & 2761 & 2549 & 0.0000 & 0.0000 \\
\hline 22 & 75 & 0.0393 & 11123090 & 0.9998 & 0.0389 & 11123090 & 0.9998 & 69526 & 2200 & 2202 & 0.9870 & 0.0556 & 2995 & 2770 & 0.0000 & 0.0000 \\
\hline 23 & 77 & 0.0415 & 11006470 & 0.9997 & 0.0411 & 11006470 & 0.9997 & 69271 & 2354 & 2356 & 0.9927 & 0.0613 & 3249 & 3021 & 0.0000 & 0.0000 \\
\hline 24 & 50 & 0.0440 & 10940630 & 0.9997 & 0.0434 & 10940630 & 0.9997 & 69039 & 2519 & 2520 & 0.9959 & 0.0645 & 3499 & 3269 & 0.0000 & 0.0000 \\
\hline 25 & 57 & 0.0467 & 10744210 & 0.9998 & 0.0458 & 10744210 & 0.9998 & 67327 & 2713 & 2715 & 1.0055 & 0.0741 & 3867 & 3640 & 0.0000 & 0.0000 \\
\hline
\end{tabular}




\begin{tabular}{|c|c|c|c|c|c|c|c|c|c|c|c|c|c|c|c|c|}
\hline $\begin{array}{c}\text { Unload } \\
\text { No. }\end{array}$ & $\begin{array}{c}\text { No. of } \\
\text { Data } \\
\text { Points }\end{array}$ & $\begin{array}{l}\text { COD } \\
\text { (in.) }\end{array}$ & $\begin{array}{l}\text { COD } \\
\text { Slope } \\
\text { (lb/in) }\end{array}$ & $\begin{array}{l}\text { COD } \\
\text { Corr. }\end{array}$ & $\begin{array}{c}\text { Loadline } \\
\text { Disp. } \\
\text { (in.) }\end{array}$ & $\begin{array}{c}\text { Loadline } \\
\text { Slope } \\
\text { (lb/in) } \\
\end{array}$ & $\begin{array}{c}\text { Loadline } \\
\text { Corr. }\end{array}$ & $\begin{array}{l}\text { Load } \\
\text { (lb.) }\end{array}$ & $\begin{array}{c}\text { COD } \\
\text { Area } \\
(\text { in-lb) }\end{array}$ & $\begin{array}{c}\text { LL } \\
\text { Area }_{\text {pl }} \\
(\text { in-lb) }\end{array}$ & $\begin{array}{c}\text { Crack } \\
\text { Length } \\
\text { (in.) }\end{array}$ & $\begin{array}{c}\text { Crack } \\
\text { Extension } \\
\text { (in.) }\end{array}$ & $\begin{array}{c}J \\
\left(\text { in }-l b / i n^{2}\right)\end{array}$ & $\begin{array}{c}J \\
\text { Plastic } \\
\left.\text { (in-lb/in }{ }^{2}\right)\end{array}$ & $\begin{array}{c}\text { CTOD } \\
\text { (in.) }\end{array}$ & $\begin{array}{c}\text { CTOD } \\
\text { Plastic } \\
\text { (in.) } \\
\end{array}$ \\
\hline 1 & 15 & 0.0006 & 15094600 & 0.9996 & 0.0010 & 15094600 & 0.9996 & 11414 & -1 & -4 & 0.8057 & -0.0932 & -3 & -7 & 0.0000 & 0.0000 \\
\hline 2 & 64 & 0.0013 & 14031350 & 0.9997 & 0.0022 & 14031350 & 0.9997 & 21357 & 2 & 13 & 0.8508 & -0.0481 & 22 & 8 & 0.0000 & 0.0000 \\
\hline 3 & 54 & 0.0020 & 13652480 & 0.9999 & 0.0036 & 13652480 & 0.9999 & 30292 & 0 & 26 & 0.8676 & -0.0313 & 49 & 21 & 0.0000 & 0.0000 \\
\hline 4 & 92 & 0.0026 & 13468390 & 1.0000 & 0.0047 & 13468390 & 1.0000 & 38972 & -1 & 43 & 0.8759 & -0.0230 & 85 & 36 & 0.0000 & 0.0000 \\
\hline 5 & 85 & 0.0034 & 13417840 & 0.9999 & 0.0061 & 13417840 & 0.9999 & 47682 & 3 & 75 & 0.8782 & -0.0207 & 138 & 65 & 0.0000 & 0.0000 \\
\hline 6 & 64 & 0.0041 & 13327650 & 0.9999 & 0.0067 & 13327650 & 0.9999 & 53080 & 19 & 106 & 0.8823 & -0.0166 & 187 & 95 & 0.0000 & 0.0000 \\
\hline 7 & 91 & 0.0053 & 13321040 & 0.9999 & 0.0085 & 13321040 & 0.9999 & 56962 & 65 & 169 & 0.8826 & -0.0163 & 258 & 152 & 0.0000 & 0.0000 \\
\hline 8 & 102 & 0.0069 & 13147840 & 0.9998 & 0.0095 & 13147840 & 0.9998 & 59204 & 149 & 268 & 0.8905 & -0.0084 & 366 & 249 & 0.0000 & 0.0000 \\
\hline 9 & 66 & 0.0092 & 13010490 & 0.9998 & 0.0128 & 13010490 & 0.9998 & 61220 & 274 & 407 & 0.8968 & -0.0021 & 515 & 387 & 0.0000 & 0.0000 \\
\hline 10 & 54 & 0.0119 & 12806640 & 0.9998 & 0.0150 & 12806640 & 0.9998 & 63345 & 432 & 583 & 0.9063 & 0.0074 & 712 & 571 & 0.0000 & 0.0000 \\
\hline 11 & 61 & 0.0137 & 12739890 & 0.9997 & 0.0177 & 12739890 & 0.9997 & 64530 & 534 & 696 & 0.9094 & 0.0105 & 835 & 688 & 0.0000 & 0.0000 \\
\hline 12 & 80 & 0.0157 & 12661280 & 0.9998 & 0.0191 & 12661280 & 0.9998 & 65555 & 658 & 832 & 0.9131 & 0.0142 & 984 & 830 & 0.0000 & 0.0000 \\
\hline 13 & 58 & 0.0168 & 12645020 & 0.9997 & 0.0203 & 12645020 & 0.9997 & 66385 & 727 & 909 & 0.9138 & 0.0149 & 1068 & 910 & 0.0000 & 0.0000 \\
\hline 14 & 67 & 0.0187 & 12488810 & 0.9998 & 0.0222 & 12488810 & 0.9998 & 67060 & 849 & 1032 & 0.9212 & 0.0223 & 1218 & 1053 & 0.0000 & 0.0000 \\
\hline 15 & 74 & 0.0205 & 12569750 & 0.9998 & 0.0250 & 12569750 & 0.9998 & 67835 & 958 & 1148 & 0.9174 & 0.0185 & 1328 & 1161 & 0.0000 & 0.0000 \\
\hline 16 & 68 & 0.0227 & 12374700 & 0.9997 & 0.0264 & 12374700 & 0.9997 & 68454 & 1106 & 1303 & 0.9266 & 0.0277 & 1525 & 1350 & 0.0000 & 0.0000 \\
\hline 17 & 73 & 0.0245 & 12364260 & 0.9998 & 0.0291 & 12364260 & 0.9998 & 69198 & 1224 & 1426 & 0.9271 & 0.0282 & 1660 & 1480 & 0.0000 & 0.0000 \\
\hline 18 & 90 & 0.0266 & 12151870 & 0.9995 & 0.0311 & 12151870 & 0.9995 & 69547 & 1366 & 1567 & 0.9372 & 0.0383 & 1859 & 1671 & 0.0000 & 0.0000 \\
\hline 19 & 67 & 0.0286 & 12223770 & 0.9996 & 0.0324 & 12223770 & 0.9996 & 70158 & 1500 & 1708 & 0.9338 & 0.0349 & 1996 & 1807 & 0.0000 & 0.0000 \\
\hline 20 & 54 & 0.0311 & 12043850 & 0.9997 & 0.0351 & 12043850 & 0.9997 & 70516 & 1671 & 1888 & 0.9424 & 0.0435 & 2241 & 2045 & 0.0000 & 0.0000 \\
\hline 21 & 50 & 0.0332 & 12108390 & 0.9998 & 0.0369 & 12108390 & 0.9998 & 69629 & 1823 & 2029 & 0.9393 & 0.0404 & 2372 & 2183 & 0.0000 & 0.0000 \\
\hline 22 & 63 & 0.0355 & 11779500 & 0.9998 & 0.0400 & 11779500 & 0.9998 & 70825 & 1981 & 2199 & 0.9551 & 0.0562 & 2677 & 2470 & 0.0000 & 0.0000 \\
\hline 23 & 54 & 0.0378 & 11742170 & 0.9997 & 0.0417 & 11742170 & 0.9997 & 70756 & 2127 & 2355 & 0.9569 & 0.0580 & 2869 & 2661 & 0.0000 & 0.0000 \\
\hline 24 & 53 & 0.0391 & 11710760 & 0.9998 & 0.0437 & 11710760 & 0.9998 & 70458 & 2223 & 2453 & 0.9584 & 0.0595 & 2993 & 2785 & 0.0000 & 0.0000 \\
\hline 25 & 42 & 0.0415 & 11706330 & 0.9998 & 0.0459 & 11706330 & 0.9998 & 69715 & 2391 & 2647 & 0.9586 & 0.0597 & 3214 & 3011 & 0.0000 & 0.0000 \\
\hline 26 & 49 & 0.0426 & 11489360 & 0.9999 & 0.0472 & 11489360 & 0.9999 & 69458 & 2467 & 2706 & 0.9691 & 0.0702 & 3377 & 3167 & 0.0000 & 0.0000 \\
\hline 27 & 43 & 0.0439 & 11547260 & 0.9999 & 0.0485 & 11547260 & 0.9999 & 69187 & 2554 & 2799 & 0.9663 & 0.0674 & 3460 & 3254 & 0.0000 & 0.0000 \\
\hline 28 & 35 & 0.0453 & 11499590 & 0.9999 & 0.0502 & 11499590 & 0.9999 & 68598 & 2648 & 2888 & 0.9687 & 0.0698 & 3584 & 3380 & 0.0000 & 0.0000 \\
\hline 29 & 51 & 0.0472 & 11194350 & 0.9998 & 0.0509 & 11194350 & 0.9998 & 65928 & 2790 & 3008 & 0.9835 & 0.0846 & 3876 & 3677 & 0.0000 & 0.0000 \\
\hline 30 & 88 & 0.0483 & 11074370 & 0.9998 & 0.0530 & 11074370 & 0.9998 & 67471 & 2845 & 3081 & 0.9894 & 0.0905 & 4047 & 3833 & 0.0000 & 0.0000 \\
\hline 31 & 45 & 0.0501 & 11031720 & 0.9999 & 0.0537 & 11031720 & 0.9999 & 60361 & 3004 & 3214 & 0.9915 & 0.0926 & 4203 & 4030 & 0.0000 & 0.0000 \\
\hline 32 & 43 & 0.0518 & 10940100 & 0.9999 & 0.0553 & 10940100 & 0.9999 & 58104 & 3118 & 3322 & 0.9959 & 0.0970 & 4391 & 4228 & 0.0000 & 0.0000 \\
\hline
\end{tabular}




\begin{tabular}{|c|c|c|c|c|c|c|c|c|c|c|c|c|c|c|c|c|}
\hline $\begin{array}{c}\text { Unload } \\
\text { No. }\end{array}$ & $\begin{array}{c}\text { No. of } \\
\text { Data } \\
\text { Points }\end{array}$ & $\begin{array}{l}\text { COD } \\
\text { (in.) }\end{array}$ & $\begin{array}{l}\text { COD } \\
\text { Slope } \\
(\mathrm{lb} / \mathrm{in})\end{array}$ & $\begin{array}{l}\text { COD } \\
\text { Corr. }\end{array}$ & $\begin{array}{c}\text { Loadline } \\
\text { Disp. } \\
\text { (in.) }\end{array}$ & $\begin{array}{c}\text { Loadline } \\
\text { Slope } \\
\text { (lb/in) }\end{array}$ & $\begin{array}{c}\text { Loadline } \\
\text { Corr. }\end{array}$ & $\begin{array}{l}\text { Load } \\
\text { (lb.) }\end{array}$ & $\begin{array}{c}\text { COD } \\
\text { Area } \\
\text { (in-lb) }\end{array}$ & $\begin{array}{c}\text { LL } \\
\text { Area } \\
(\text { in }- \text { lb })\end{array}$ & $\begin{array}{c}\text { Crack } \\
\text { Length } \\
\text { (in.) }\end{array}$ & $\begin{array}{c}\text { Crack } \\
\text { Extension } \\
\text { (in.) }\end{array}$ & $\begin{array}{c}\mathrm{J} \\
\left(\mathrm{in}-\mathrm{lb} / \mathrm{in}^{2}\right)\end{array}$ & $\begin{array}{c}\text { J } \\
\text { Plastic } \\
\left(\mathrm{in}-\mathrm{b} / \mathrm{in} \mathbf{i n}^{2}\right)\end{array}$ & $\begin{array}{l}\text { CTOD } \\
\text { (in.) }\end{array}$ & $\begin{array}{c}\text { CIOD } \\
\text { Plastic } \\
\text { (in.) }\end{array}$ \\
\hline 1 & 54 & 0.0022 & 14160080 & 0.9999 & 0.0022 & 14160080 & 0.9999 & 30042 & -2 & 6 & 0.8452 & -0.0104 & 38 & 12 & 0.0000 & 0.0000 \\
\hline 2 & 71 & 0.0030 & 14143480 & 0.9999 & 0.0034 & 14143480 & 0.9999 & 40386 & 2 & 38 & 0.8459 & -0.0096 & 87 & 39 & 0.0000 & 0.0000 \\
\hline 3 & 66 & 0.0038 & 14154300 & 0.9999 & 0.0043 & 14154300 & 0.9999 & 50103 & 7 & 65 & 0.8455 & -0.0101 & 135 & 62 & 0.0000 & 0.0000 \\
\hline 4 & 114 & 0.0050 & 14062170 & 0.9999 & 0.0065 & 14062170 & 0.9999 & 60054 & 36 & 119 & 0.8495 & -0.0061 & 215 & 108 & 0.0000 & 0.0000 \\
\hline 5 & 55 & 0.0062 & 14234490 & 0.9998 & 0.0076 & 14234490 & 0.9998 & 63831 & 94 & 199 & 0.8420 & -0.0136 & 290 & 172 & 0.0000 & 0.0000 \\
\hline 6 & 79 & 0.0077 & 13832250 & 0.9998 & 0.0098 & 13832250 & 0.9998 & 65508 & 189 & 313 & 0.8596 & 0.0040 & 410 & 279 & 0.0000 & 0.0000 \\
\hline 7 & 100 & 0.0098 & 13809030 & 0.9997 & 0.0113 & 13809030 & 0.9997 & 67216 & 309 & 435 & 0.8606 & 0.0051 & 524 & 385 & 0.0000 & 0.0000 \\
\hline 8 & 55 & 0.0123 & 13819300 & 0.9999 & 0.0142 & 13819300 & 0.9999 & 69402 & 470 & 612 & 0.8602 & 0.0046 & 685 & 538 & 0.0000 & 0.0000 \\
\hline 9 & 72 & 0.0150 & 13653320 & 0.9998 & 0.0176 & 13653320 & 0.9998 & 71147 & 648 & 822 & 0.8676 & 0.0120 & 892 & 734 & 0.0000 & 0.0000 \\
\hline 10 & 95 & 0.0181 & 13656640 & 0.9999 & 0.0203 & 13656640 & 0.9999 & 72519 & 861 & 1035 & 0.8674 & 0.0118 & 1086 & 922 & 0.0000 & 0.0000 \\
\hline 11 & 70 & 0.0215 & 13452440 & 0.9996 & 0.0239 & 13452440 & 0.9996 & 74588 & 1100 & 1286 & 0.8766 & 0.0210 & 1347 & 1169 & 0.0000 & 0.0000 \\
\hline 12 & 86 & 0.0245 & 13307010 & 0.9996 & 0.0274 & 13307010 & 0.9996 & 75698 & 1315 & 1512 & 0.8832 & 0.0276 & 1582 & 1395 & 0.0000 & 0.0000 \\
\hline 13 & 55 & 0.0276 & 13349540 & 0.9999 & 0.0295 & 13349540 & 0.9999 & 75633 & 1550 & 1739 & 0.8813 & 0.0257 & 1782 & 1597 & 0.0000 & 0.0000 \\
\hline 14 & 74 & 0.0308 & 13029010 & 0.9996 & 0.0335 & 13029010 & 0.9996 & 77742 & 1788 & 2006 & 0.8960 & 0.0404 & 2112 & 1907 & 0.0000 & 0.0000 \\
\hline 15 & 51 & 0.0338 & 12949110 & 0.9996 & 0.0361 & 12949110 & 0.9996 & 78234 & 2003 & 2227 & 0.8997 & 0.0441 & 2346 & 2136 & 0.0000 & 0.0000 \\
\hline 16 & 51 & 0.0366 & 12738340 & 0.9997 & 0.0388 & 12738340 & 0.9997 & 78583 & 2220 & 2440 & 0.9095 & 0.0539 & 2616 & 2397 & 0.0000 & 0.0000 \\
\hline 17 & 62 & 0.0396 & 12704660 & 0.9998 & 0.0416 & 12704660 & 0.9998 & 76563 & 2461 & 2658 & 0.9111 & 0.0555 & 2832 & 2623 & 0.0000 & 0.0000 \\
\hline 18 & 52 & 0.0428 & 12512870 & 0.9997 & 0.0449 & 12512870 & 0.9997 & 78387 & 2697 & 2913 & 0.9201 & 0.0645 & 3167 & 2942 & 0.0000 & 0.0000 \\
\hline 19 & 38 & 0.0462 & 12520820 & 0.9998 & 0.0481 & 12520820 & 0.9998 & 75024 & 2979 & 3178 & 0.9197 & 0.0641 & 3416 & 3210 & 0.0000 & 0.0000 \\
\hline 20 & 57 & 0.0494 & 12169210 & 0.9996 & 0.0517 & 12169210 & 0.9996 & 77752 & 3220 & 3445 & 0.9364 & 0.0808 & 3866 & 3632 & 0.0000 & 0.0000 \\
\hline 21 & 36 & 0.0515 & 12184750 & 0.9996 & 0.0537 & 12184750 & 0.9996 & 74848 & 3383 & 3590 & 0.9356 & 0.0801 & 3998 & 3782 & 0.0000 & 0.0000 \\
\hline 22 & 53 & 0.0555 & 11644910 & 0.9997 & 0.0575 & 11644910 & 0.9997 & 73833 & 3694 & 3905 & 0.9616 & 0.1060 & 4653 & 4423 & 0.0000 & 0.0000 \\
\hline
\end{tabular}

